3.

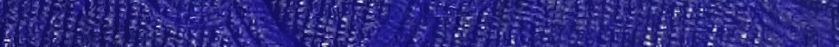

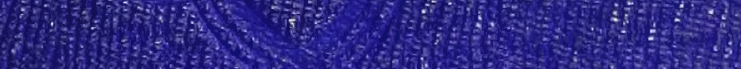

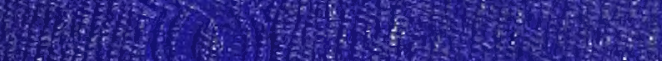

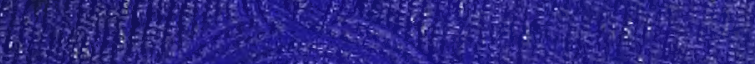

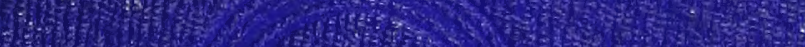

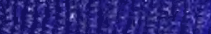

7.

30

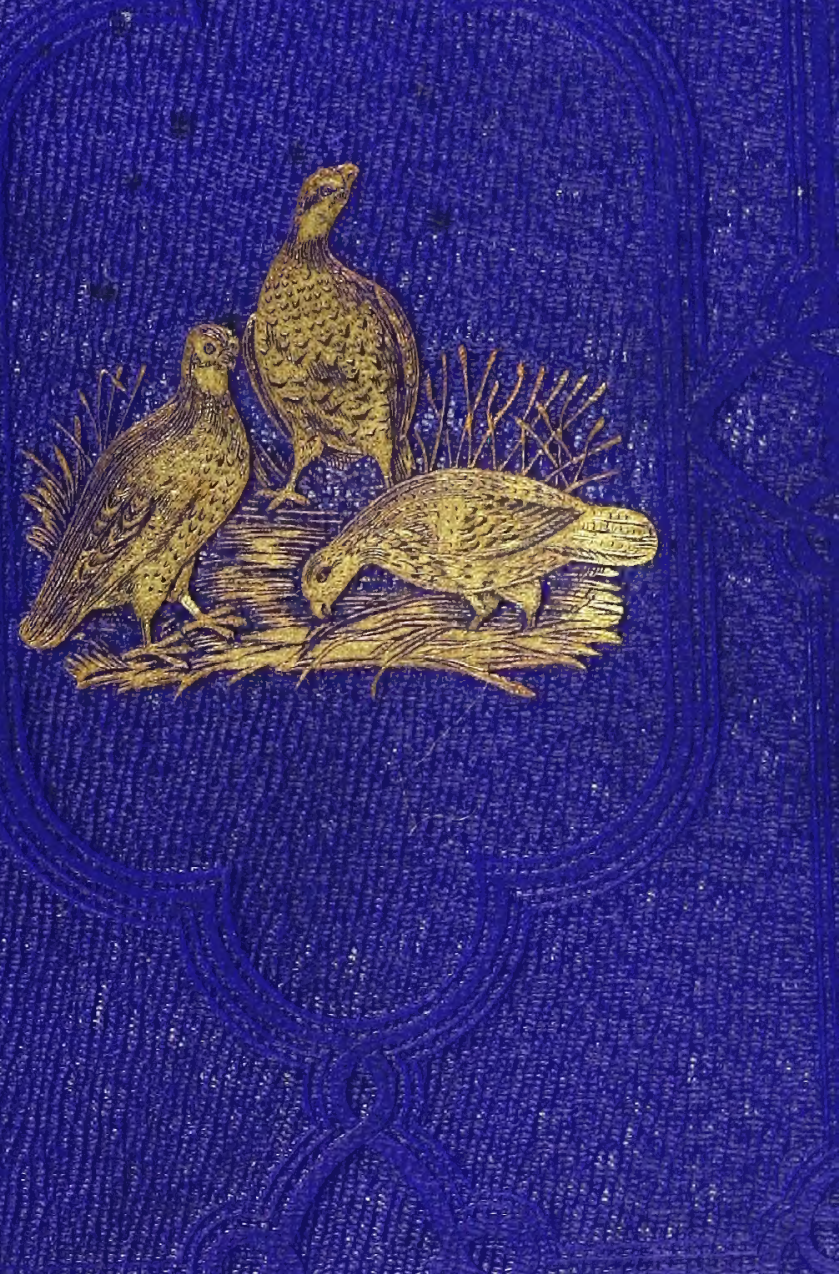




\section{Cornell Universitp}

\section{Líbrary}

OF THE

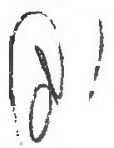

Hew Work Ftate College of foregtry

Fin 618 $14-3 / 1900$

RETURN TO

ALBERT R. MANN LIBRARY

ITHACA, N. Y. 


\section{Cornell University Library}

SK 41.453

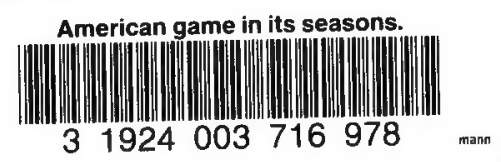




\section{Cornell University Library}

The original of this book is in the Cornell University Library.

There are no known copyright restrictions in the United States on the use of the text. 





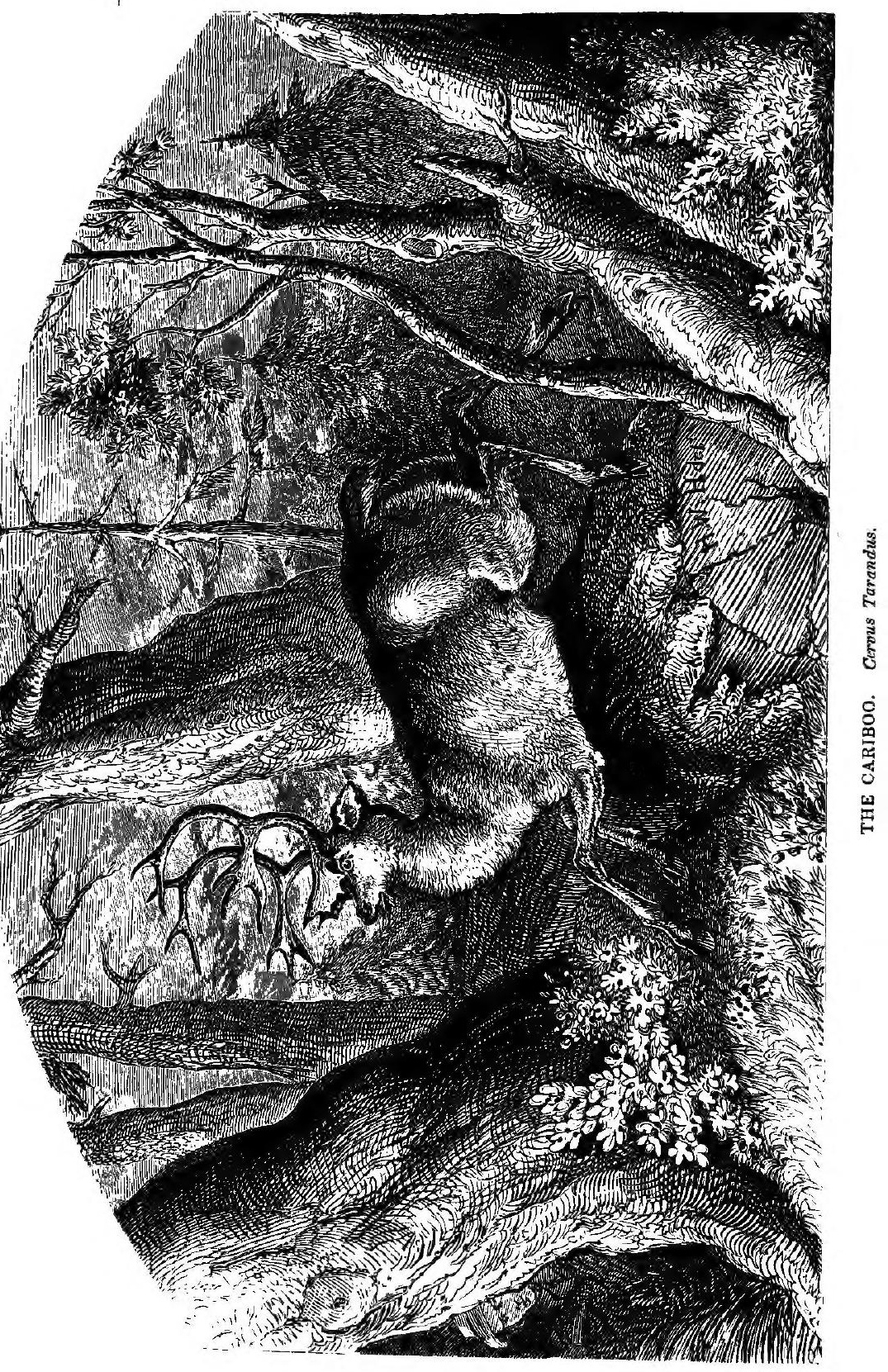






\section{A M E R I C A N G A M E}

\section{IN ITS SEASONS.}

BY

\section{HENRY WILLIAM HERBERT,

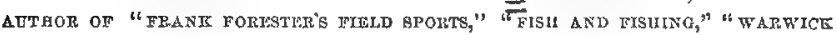 WOODLANMG," "MY BIOO'TING BOX," "THE DERR-GTALIKHRS," FTC, RTO.}

' ILLUSTRATED FROM NATURE,

AND ON WOOD, BX TME AUTIIOR.

NEW YORK :

CHARLES SCRIBNER, 145 NASSA'U STREET.

1853. 
Entered according to $\Lambda$ ct of Congres, in the year 1858 , by

CHARL.ES S C liL I $\mathrm{N}$ E R,

In tle Clerk's Oflice of the District Cont of the Tinited Stutes for the Sonthern District of New York.

C. W. BENEDIUT,

201 William Street, N. T. 


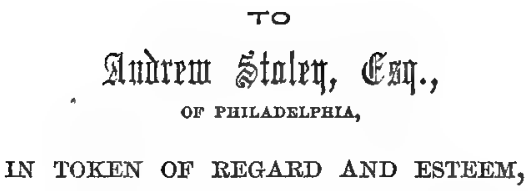

\section{THIS LITTLE VOLUME}

IS RESPETFULIT DEDIOATED, BY HIS

FELLOW-COUNTRYMAN, FELLOW-SPORTSMAN, AND FRIEND,

HENRY WM. HERBER I.

Thim Cradare, January 10, 1858. 



\section{ILLUSTRATI ON S.}

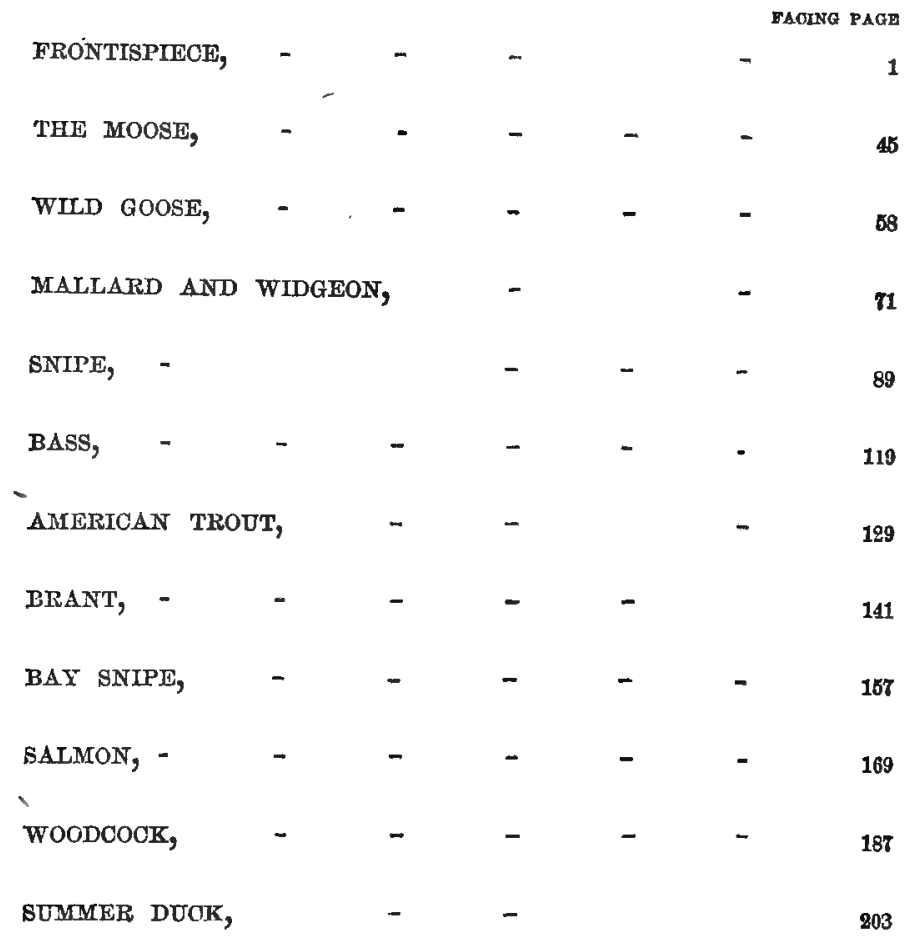




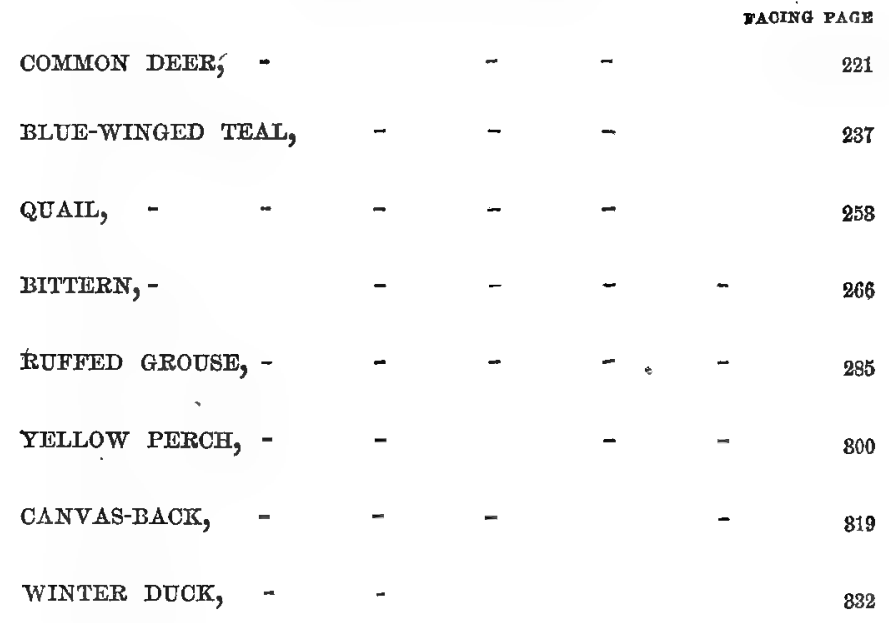




\section{ADVERTISEMENT.}

Thrs volume, which is now for the first time submitted to the public in a connected form, is composed for the most part of papers which have appeared from time to time in the pages of Graham's excellent magazine, under the running title of "The Game of the Month." It does not profess to contain complete accounts of every species of game, found or pursued within the wide limits of the United States of America-that must be looked for in works of wider scope and larger pretensions, whether by the author or others.*

All that it aims at doing is to set some of the principal and most highly esteemed varieties before the general reader, in a light and attractive style, with some

* I may here mention, "Hawker on Shooting," American Edition, by William T. Porter ; "Frank Forester's Field Sports," aud "Fish and Fishing," by Henry William Herbert; and "Hints to Sportsmen," by E. I. Lewis; all of which works have found favor with the public, and are admitted standards. 
account of their specific distinctions and characteristics in a zoological point of view; of their habits, haunts, and migrations; and of their season in different parts of the vast demesnes owned by the American people; not what is esteemed the most sportsmanlike and scientific mode of pursuing, killing, and when killed, cooking them for the table.

The leading idea of the plan was to adopt for each month in the year the finest, and most generally, favorite species of game, with reference principally, as regards season, to the Northern, Midland, and Northwestern portions of the United States and Canada, though the animals described are common more or less to all sections of the country.

The somewhat rambling and irregular plan of the series renders any apology for this or that species of game wholly unnecessary, since, in the first place, it never was intended to constitute a perfect natural history of all the game, birds, beasts, and fishes of America, but merely a series of sketchy papers; and in the second, because the series is yet in progress, and whenever it may appear desirable, or be called for by public favor, another volume or volumes may be from time to timo presented. 
The illustrations are all designed and drawn on wood from nature, by the author, with two exceptions, "the Bittern," and "the Yellow Perch," which were copied from correct representations, owing to the impossibility of procuring specimens at the moment when they were required. It is believed that they will be found correct as zoological representations; while the beautiful and elaborate work of Messrs. Brightly and Devereux's gravers cannot fail to obtain the admiration it merits.

I have only to acknowledge my obligations to the officers of the Lyceum of Natural History, in Philadelphia, and to Mr. Bell, the celebrated Taxidermist in New York, for the facilities they have kindly afforded me in obtaining specimens for this and former works; and to submit my little work to the consideration of my friends of the sporting world, and the larger circle of the reading public.

HENRY WM. HERBERT.

January 10, 1853. 



\section{0 N TENTS.}

GAME IN ITS SEABONS.

JANUARY.

PAGR

The Cariboo or American Reindebr. Cervus Tarandus. -

\section{FEBRUARY.}

The Moose Deer. Cervus Alces. - - - $\quad 45$

Тнн Wild Goose. Anas Canadensis. - _ - - 58

\section{MARCH.}

The Maliard and Widgeon. Anas Bosclas. Anas Americara. 71

APRIL.

The American Snipe. Scolopax Wilsonii. - - - $\quad$ - $\quad-89$

Strtped Bass. Labrax Lineatus. - - - - - $\quad$ - 119

\section{MAY.}

The American Trout. Salmo Fontinalis. - - - - 129

THE BRent Goose. Anas Bernicla. - - - - $\quad$ - 141 
JUNE.

Bat Snipe. Hudsonian Godwtt. Limosa Hudsonicn. Tue RedBReasted Snipe, Scolopax Noveboracensis. - 157

The Salmon. Salmo Salar. - - - - - - - 169

JULY.

The Woodcock. Scolopax Minor, sive Microptera Americana. 187

AUGUST.

'The Sumar Duck. Anas Sponsa sive Dendronessa.

203

Tae Common Deer. Cervus Virginianus.' - $\quad$ - 221

SEPTEMBER.

The Buue-Winged Teal. The Green-Winged Teal. Anas

Dicors. Anas Carolinensis. - _ - - - - 237

OCTOBER.

The Quall. Ortyx Virginionus. - - - - - $\quad 253$

The Bittern. Arlea Lentiginosa. - - - - - $\quad$ - 266

NOVEMBER.

The Ruffed Grouse. Tetrao Umbellus. - - - $\quad$ - 285

The Yeldow Perge. Perca flavescens. - - - - - 300 


\section{DECEMBER.}

The Canras-Back. Anas Valisneria. - - - - $\quad$ - 319

The Wrater Duck. Fuligula Bimaculata - - 332 



\section{I.}

\section{JANUARY.}

\section{The curiboo.}

\section{THE MMERICAN REINDEER,}

Corvus Turandus.

ARCTIC REGIONS-NEWFOUNDLAND TO NEW YORK. 



\section{THE CARIBOO.}

AMERICAN REINDEER.-Cervus Tarandus.

Habitat ; from Newfoundland, through all the British provinces and possessions so far north as the artic seas, to the northern part of the State of New York. The Cariboo is not found south of the St. Lawrence, farther west that the Black river, nor on the great lakes westward of the Ottawa.

It is said that there exists several varieties of this splendid stag in the extreme northern regions, though they have not been defined even by the recent bold and scientific explorers of those inhospitable climes.

I have, however, recently satisfied myself that there are, if not in Canada, at least in Newfoundland, two distinct varieties of Cariboo, one vastly superior in size to the other, and characteristically separated from the smaller, by the form and structure of its horns. Of this I am satisfied, by the examination of a pair of antlers, lately exported from that curious and interesting island, by my friend, Dr. Hugh Caldwell, which differs entirely from those in my own possession, which furnished the models for my frontispiece, and from many specimens 
in the office of the "Spirit of the Times," all brought from the same island, by the late Mr. Henry Palmer, of New Brunswick.

The general characteristics of this huge deer, inferior only in size to the Moose deer, Cervus Alus, of the same regions, and to the Wapiti, Round Horn, or American Eik, Cervus Canadensis, of the far west, differing and distinguishing it from all other animals of the same species, are first: The peculiar structure of its horns, combining the properties of the palmated and furcated structures. Second, The length and looseness of its pelage, and the shortness of its tail, which rather resembles the scut of a hare, than the long flag of a deer; and thirdly, The extreme cleft of its hoofs and feet, extending up the pasterns, nearly to the fetlock joint. A structure to which this animal owes its great facility in traversing the treacherous snow drifts, is the unparalleled spread of its hoofs and pasterns, the whole length of which rests on the surface over which it bounds, when in full action, up to the fetlock, supporting it where small-footed animals of inferior size and weight would sink up to the belly at every stride, and where man himself labors even with the mechanical aid of snow-shoes.

In speaking of the color of the Reindeer below, as the most grizzly and lightest colored of its tribe, I am not certain that I have not fallen into the error of assigning the characteristic coloring of one, the Newfoundland variety, and possibly the winter coloring of that, as general 
among the race. Mr. Wallop speaks of their "darkbrown hides," and some Canadian sportsmen have objected to my description; still I prefer letting what I have written stand, since I wrote from actual inspection of Newfoundland Cariboo skins; and until I have seen others of darker hue, must hold in absence of other proof what I have seen to be true.

If the Cariboo of the other British provinces, and the North-eastern States of America, differ in color from those of Newfoundland, my too general statement may perhaps tend to elicit further information, by which the numbers and distinctions of the several varieties may be definitively attained.

It is not a little extraordinary, that this magnificent and noble species, which exists in considerable numbers within two hundred miles of the spot where I sit writing, in the Adirondack Highlands-I mean of New Yorkwhich abounds in the north-eastern part of Maine, swarms in New Brunswick and Newfoundland, and indeed everywhere North of the St. Lawrence and Ottawa, to the extremest Arctic Regions yet penetrated by the foot of man, should be yet less known to American writers-even on the topic of Natural History-than most animals of Central Asia, or the inhospitable wilds of Southern Africa. It is not even determined-so little care has been taken in examining or identifying specimens -whether it is one and the same, or a different species from the Reindeer of the Europe-Asiatic continent; nor 
have any of its peculiarities been noted down, such as the common indications of its stature, antlers, pelage, and color, much less its anatomical and osseous structure, so as to permit of any accurate comparison being drawn, or decision arrived at.

In proof of the loose way in which these self-styled descriptions of rare animals are drawn, in books of solemn pretension and supposed authority, I shall proceed to quote the following from the Encyclopædia Americana-a work of which I can only say, that it is equally profuse of needless information on subjects trite to every Sophomore, and sparing of facts, such as require research and are required by men of ordinary reading, who will search its pages vainly for what on occasion they may need to ask it.

"Reindeer"-says the authority. "These animals inhabit the Arctic Islands of Spitzbergen, and the northern extremity of the Old Continent, never having extended, according to Cuvier, to the southward of the Baltic. They have been" long domesticated, and their appearance and habits are well described by naturalists. The American Reindeer, or Cariboo, are much less generally known; they have, however, so strong a resemblance to the Lapland deer, that they have always been considered to be the same species, though the fact has never been completely established. The American Indians have never profited by the docility of this animal, to aid them in transporting their families and property, though they 
annually destroy great numbers for their flesh and hides. There appear to be several varieties of this useful quadruped peculiar to the high northern regions of the American Continent, which are ably described by Dr. Richardson, one of the companions of Captain Franklin, in his arduous attempt to reach the North Pole by land. The closeness of the hair of the Cariboo, and the lightness of its skin, when dressed, render it the most appropriate article for winter clothing in the-high latitudes. The hoofs of the Reindeer are very large, and spread greatly, and thus enable it to cross the yielding snows without sinking."

And this-without one word of its height, weight, color, or habitat-is the only information which the Editor of the American Encyclopædia thinks proper to give lis readers-except a brief description of Dr. Richardson, about whom he seems to know a little, if he knew nothing about Cariboo-concerning an animal, which is killed almost annually within fifty miles of Albany, sold annually in Montreal, and in New Brunswick and Nova Scotia almost as common an article as venison, or Mloose-meat during winter in the markets.

Would not any one suppose, on reading the above, that he was dealing with the description of an animal, which roamed only wastes untrodden by the foot of the white man, save the adventurous explorers of the Arctic Circles, and concerning which no information can be gained by the ordinary naturalists of this country? 
Cuvier and Richardson, and Auduhon's stupendous work are not attainable by general readers, or even ordinary writers of cities; to those of the country they are utterly inaccessible-but to Encyclopædists, and to men who sit down to reproduce great works on Natural History, who choose to consult them, they are perfectly and easily open; and there is no shadow of excuse for those who profess to teach others, yet refuse to learn themselves.

Had the writer of the above worthless trash thought fit to compare Dr. Richardson's description of the Cariboo, which it seems he had read-and which, like all that singularly able naturalist's descriptions, is doubtless as minute as correct-with Cuvier's description of the Reindeer, he might have pronounced as easily as he could whether two and two makes four or five, whether the American and Europe-Asiatic deer are identical or different. Godman, in his "Quadrupeds of North America," though a little more definite than Dr. Leiber", is scarce less bold and brief. Dr. Dekay, whose lamented life has recently been brought to an untimely close, though he suspected it to be a denizen of New York, was not fully assured of the fact, and therefore has not, I think, described it in his Fauna of that State.

I have myself, unfortunately, no immediate access to either.Richardson or Cuvier; nor even to any well established work on the Animals of Northern Europe. But 
I have seen a large herd, in my youth, of tho Lapland Reindeer, which, with their Esquimaux attendants, were exhibited many years ago in London; previous to a futile attempt at naturalizing them in the Highlands and Western Isles of Scotland; and luave a fair general remembrance of the animal. I possess antlers of the Cariboo, which hang in my hall, and which are accurately portrayed in the wood-cut; I have handled twenty times the hides of this great deer; and I hare daily opportunities-in the office of my friend, W. T. Porter, of the Spirit of the Times-to examine the preserved heads and legs of even finer specimens than my own. I have also letters, private, and writings published, of a New Brunswicker, who has killed the Cariboo fifty times, and had opportunities of seeing the Europe:n Reindeer, at the Zoological Gardeus in London, long since myself. I can, therefore, form a very fair conjecture at the identity or non-identity of the species. At least, I can give some particulars of structure, stature, and pelage of the American Cariboo, which will enable othcrs to judge, who are better posted up than I, in the pecrliarities of the Lapland Reindeer. And first--I will premise that althongh I lave never seen the Cariboo in life, or in his native woods-which I trust to do before the snows of the next March shall hare melted-the wood-cut illustration of this number is so closely made up from measurements of the various parts, heads, antlers, legs and hides of the animal, that I believe it to be 
as nearly correct as any likenoss can be, which is not taken from an especial individual of the race.

In the first place-as to the stature of the Cariboo, I was long ago struck by the statements of the New Brunswick writer, "Mradows," alias Mr. Barton Wallop, alluded to above, which may be found in Porter's edition of Hawker's Field Sports, p. 326-333-“"The Cariboo of this country are very like the Reindeer, only a little larger"-and again-"As this is the first time you have seen a Cariboo trail, you will observe it is much like that of an $o x$, save that the cleft is much more open, and the pastern of the animal being very long and flexible, comes down the whole length on the snow, and gives the animal additional support."

Arguing on this statement, in my "Field Sports," knowing MEadows to have seen both animals, that they must be distinct, I pointed out that no one could dream of comparing a Lapland Reindeer's track to that of an ox, any more than to that of an elephant; and observed farther, that the Lapland Reindeer is not a larger, but, to my recollection, a smaller animal than the common American Red-deer, Cenvus Virginianus of Naturalists. This coming casually under Mr. Wallop's, ‘eye, he wrote to me, in full confirmation of my opinion, that he had recently seen Lapland Reindeer in the Regent's Park Zoological Gardens, and wished to amend his former dictum, by saying, that the Cariboo is at least one-third taller than the Lapland deer, and otherwise larger, and 
in other respects very different. Also that the Lapland animal is not taller than the British stag, or the American Common Deer, or, if at all, very slightly so.

Now, to come to my own obserration, rerified by measurement. The Cariboo antlers in my own possession, not an unusually large pair, measure as follows :

Extreme width from tip to tip, one foot four and a half inches. Length of currature of antlers, from root to tip, two feet three and a half inches. Direct height, twenty-three incles. Breadih of the palmated brow antlers, eight inches. Length of do, eleven inches. Breadth of upper palm, eight inches. Length of do., twelve inches. Girth at the root of antler, five and a half inches. At insertion of upper prong, four inches. Number of prongs at the tips, unequal-three and two. At the upper palms, three. On the lower palms, seren processes, including the principal point.

Compare with this, the mcasurements of the antlers of a rery fine specimen of the common Anerican deer, Cerrus Tirginianus.

Extreme width from tip to tip, cleren inches. Length of currature along the back of antlers from root to tip, two feet and half an inch. Direct height, fifteen inches.

Observe, howerer, that the greater curvature in the horns of the American deer, while it causes a larger comparatire measurement, leares a rast excess in height and show to the Cariboo.

In the Cariboo, moreorer-see cut-the structure of 
the horns is directly the reverse of that of any other palnated-horned animal I ever remember to have seen; as the Moose, the English Fallow-deer, and to the best of my recollection the Europe-Asiatic Reindeer. In both the former of these animals, the broad palms form the extreme upper tips; while the lower spurs and brow antlers are round prongs; and, to the best of my memory, the Reindeer has no very conspicuous palms at all.

In our common deer, again, contrary to any other deer I have ever seen-except a very noble nondescript, specimen recently sent from Calcutta to the Spirit of the Times-the main branch of the antlers curves forward over the brow, offering the main defenses, the true brow antlers being mere erect prongs; while all the tines are posterior to the main branch.

In the American Elk, and in the British Stag, or Red. deer, and in all other round-horned deer I ever saw, the main antlers rise erectly, with a slight backward curve, the brow antler and all the other tines springing from it anteriorly, and forming the true weapons for the animal's defense.

The Cariboo, therefore, presents a curious combination of the round-horned and palmated-horned deer, in the first instance ; and of the usual, and American, roundhorn structure, in the second. First, it has the round, pointed tips and sharp, round prongs of the round-horned deer above, with the flat, leaf-like blades of the palmated-horned deer below. And, secondly, it has the 
forward curve at the tips and backward prongs, above, of the American round-horn, with the terrible brow antlers and forward tines of the usual structure below.

Lastly, it differs from all in this-that its brow antlers, instead of dividing with an outward curve over and without each eye, close with a straight inward inclination, until the tips almost meet, nearly in the centre of a brow.

Once more, as to size, there are the leg, with hoof, pastern and cannon-bone of an ordinary sized Cariboo; and the leg, with hoof, pastern and cannon-bone of an extraordinarily large-sized American deer, and as such selected, hanging side by side in Mr. I'orter's office. The limb of the Cariboo is considerably more than onethird superior in size to that of the common deer, and is fully equal to that of a yearling heifer of the very largest stature, and from its peculiar structure, being cleft nearly the full length of the pastern to the fetlock-joint, would eridently leare a much larger track.

I have seen and ridden aged thorough-bred horses of fourteen and a half hands-four feet ten inches highwhose limbs were in all respects inferior to that of this superb specimen of the deer tribe; and right confident am I, from observation of sereral of their heads, their hides and hoofs, that from fourteen and a half to fifteen hands will be found to be the arerage height of the Cariboo. If the Lapland Reindeer ever exceeds thirteen it will be surprising to me. While on this topic, how- 
ever, I will beg the first Canadian or Nova Scotian hunter whose eye this may meet, to furnish me with the full statements of height, weight and measurement of any Cariboo he may be so fortunate as to kill, or to hare killed, during the present winter. Readers of Graham will find in the February number of the year 1852, a correct and spirited representation of the antlers of the English Red-deer; and, if they will look forward to the months of February and August of this volume, they will find those of the Moose and American Deer, designed by myself from the life, which will far more easily convey the comparison which I desire to draw, than written words.

As regards the nature of the pelage, or fur, for it is almost such, of the Cariboo, so far from its being, as the wiseacre of the Encyclopædia states, remarkable for closeness and compactness, it is by all odds the loosest and longest haired of any deer I ever saw; being, particularly about the head and neck, so shaggs as to appear almost maned.

In color, it is the most grizzly of deer, and though comparatively dark brown on the back, the hide is generally speaking, light, almost dun-colored, and on the head and neck fulvours, or tawny gray, largely mixed with white hairs.

The flesh is said to be delicious; and the leather made by the Indians from its skin, by their peculiar process, is of unsurpassed excellence for leggins, moccasons or 
the like; especially for the moccason to be used under snow-shoes.

As to its habits, while the Lapland or Siberian Reindeer is the tamest and most docile of its genus, the $\Delta$ merican Cariboo is the fiercest, fleetest, wildest, shyest and most untameable. So much so, that they are rarely pursued by white hunters, or shot by them, except through casual good fortune; Indians alone liaving the patience and instinctive craft, which enables them to crawl on them.unseen, unsmelt-for the nose of the Cariboo can detect the smallest taint upon the air of anything human at least two miles up wind of him-and uususpected. If he takes alarm and start off on the run no one dreams of pursuing. As well pursue the wind, of which no man knoweth whence it cometh or whither it goeth. Snow-shoes against him alone avail little, for propped up on the broad, natural snow-shoes of his long, elastic pasterns and wide cleft clacking hoofs, he shoots orer the crust of the decpest drifts, unbroken; in which the lordly moose would soon flounder, shoulder deep, if hard pressed, and the graceful deer would fall despairing, aud bleat in vain for mcrey - but he, the ship of the winter wilderness, outspeeds the wind amoug his native pines and tamaracks-eren as the desert ship, the dromedary, onttrots the red simoon on the terrible Zaharaand once started, may be seen no more by himan eyes, nor run down by flectest feet of man, no, not if they pursue him from their nightly-casual camps, unwearied, 
following his trail by the day, by the week, by the month, till a fresh snow effaces his tracks, and leaves the hunter at the last, as he was at the first of the chase; less only the fatigue, the disappointment and the folly. Therefore, by woodsmen, whether white or red skinned, he is followed only on those rare occasions when snows of unusual depth are crusted over to the very point at which they will not quite support this fleet and powerful stag. Then the toil is too great even for his vast endurance, and he can be run down by the speed of men, inured to the sport, and to the hardships of the wilderness, but by them only. Indians by hundreds in the provinçes, and many loggens and hunters in the Eastern States, can take and keep his trail in suitable weatherthe best time is the latter end of February or the beginning of March; the best weather is when a light, fresh snow of some three or four inches has fallen on the top of deep drifts and a solid crust; the fresh snow giving the means of following the trail; the firm crust yielding a support to the broad snow-shoes and enabling the stalkers to trail with silence and celerity combined. Then they crawl onward, breathless and voiceless, up wind always, following the foot prints of the wandering, pasturing, wantoning deer ; judging by signs, unmistakable to the veteran hunter, undistinguishable to the novice, of the distance or proximity of their game, until they steal upon the herd 'unsuspected, and either finish the day with a sure shot and a triumphant whoop; or 
discover that the game has taken alarm and started on the jump, and so give it up in despair.

One man perhaps in a thousand can still-hunt, or stalk, Cariboo in the summer season. He, when he has discovered a herd feeding up wind, at a leisure pace and clearly unalarmed, stations a comrad in close ambush, well down wind and to leeward of their upward track, and then himself, after closely observing their mood, motions and line of course, strikes off in a wide circle well to leeward, until he has got a mile or two alead of the herd, when very slowly and guardedly, observing the profoundest silence, he cuts across their direction, and gives them his wind, as it is technically termed, dead ahead. This is the crisis of the affair ; if he gire the wind too strongly, or too rashly, if he make the slightest noise or motion, they scatter in an instant, and away. If he give it slightly, gradually, and castally as it were, not fancying themselves pursued, but merely approached, they merely turn away from the remote danger, and instead of flying, feed away from it, working their way down wind to the deadly ambush, of which their keenest scent cannot, under such circumstances, inform them. If he succeed in this inch by inch he crawls after them, never pressing thein, or drawing in upon them, but preserving the same distance still, still giving them the same wind as at the first, so that he creates no panic or confusion, -until at length, when close upon the hidden peril, his sudden whoop sends them 
headlong down the deceitful breeze upon the treacherous rifle.

Of all wood-craft, none is so difficult, none requires so rare a combination as this, of quickness of sight, wariness of tread, very instinct of the claft, and perfection of judgment. When resorted to, and performed to the admiration even of wosdmen, it does not succeed once in a Inundred times-therefore not by one man in a thousand is it ever resorted to at all, and by him, rather in the wantonness of wood-craft, and by way of boastful experiment, than with any hope, much less expectation of success.

For once, in myillustration, the trick has been played, and the game wins - the whoop is pealing on the wiud beyoud the dark, sheltering pines and hemlocks-the herd is scattered to the four winds of heaven--but the monarch of the wilderness, the prime bull of the herd, bears down in his headlong terror full on the ambushed rifle.

Lo! with how brave a bound he clears that prostrate log. But the keen eye of the woodman is upon him; another moment, and it shall glare along the deadly rifle; the sharp, short crack shall awake the echoes of the forest, and ere they shall have subsided into silence, the pride of the woods shall have gasped out his last sigh on the gory green-sward.

But this you will say is fancy-scarcely fact. Be it so. What follows shall be fact, not'faucy. For I shall 
beg leave to quote a few pages from Porter's Hawker by that "Meadows," whom I have already mentioned-since his is the best description of this noble sport extant; since to reproduce it, giving his thoughts in my own altered words were worse than plagiary; and since, if it meet his eye, he will be rather pleased than hurt that I have winged his words into a wider field, and to a larger andience than he at first addressed them.

I will premise only, that " Howard," who figures as the hero, is a New Brunswicker, in New Brunswick; "Meadows," the narrator, an English tyro visiting his friend in the province; Sabatisie, a Micmac Indian, henchman and guide of Meadows; and Billy, last not least, Howard's pet bull-terrier. Scene, daybreak! they have issued from the camp close to the lnunting-ground where the Cariboo are supposed to "won"-as Chaucer would have witten it-when lo! quoth Meadows-

"After a hearty meal, every thing being ready, we mounted our snow-shoes and marched. The first golden rays were just struggling through the gray East, and dispersing the thick mist which hung over our camp, as I strole forth on my first Cariboo hunt, my heart leaping in anxious anticipation, and my nerves strung by the healthy atmosphere. We proceeded in silence, and had ample time to observe the lonely grandeur of the surrounding forest; the death-like stillness enlivened only by the cheerful chirp of the active ground-squirrel, or the loud boring of that most beautiful of woodpeckers, 
the Hid. We crossed Cariboo tracks at erery step, but still the Indian proceeded, his quick eye glancing at every trail. After about an hour's walk, we found ourselves ascending a steep mountain. Here the. Indian came to a halt: in a low tone he told us that we were now near the Cariboo ground, this being the warm side of the hill, and good feeding ground; cautioning us to be quiet, we again advanced, but had not gone far before we came to a trail that the Indian said was only made last night. Sabatisie chose the outside track of the herd, to take the wind-which, having followed about three miles, brought us to where the Cariboo had rested during the night. Tom placed his hand on the damp snow, and remarked that the Cariboo had not been up much before us, and could not be far off.

"Rifles were now examined, and fresh caps put onBilly secured by a cord to Howard's belt. The tracks from the resting-place of the Cariboo branched off in every direction; and the Indian leaving us, took a cast round, some distance, and having ascertained the direction the herd had taken, he returned, and we cantiously followed him. I now perceived that at the bottom of the tracks the snow was a deep blue, and quite soft; we were therefore quite near the game. Sabatisie halted and took off his snow-shoes that he might proceed with less noise. Howard beckoned me to him, and in a low whisper said-'Do exactly as you see me do-follow 
close upon my track, and do not for your life make the slightest noise-we are close on them!'

"Sabatisie and Howard now slung their snow-shoes on their backs: to prevent the crackling of the crust, the Indian with his fingers broke the snow before him, and placing his foot in the hole he made, quietly advanced-Howard putting his in the track the Indian had left, I mine in Howard's. By this means we proceeded without the slightest noise; and as our movements were simultaneous, we should to a person in front appear as one body. Our situation was anything but agreeable, up to the waist in snow. The trail became every moment more fresh, and the eagle eye of our sagacious guide pried far into the depths of the forest in front. Suddenly he cast himself at full length on the snow, and remained so long in that position that I innocently thrust my head out of the line to see what was the matter; but the Indian glared at me with anger and contempt, and Howard's sign recalled my senses. In front, the wood being quite open, Sabatisie had seen the Cariboo, and now made for a large pine to shelter his approach. His movements, as he dragged himself along on his belly in the snow, were snake-like; and we followed, endeavoring as far as possible to imitate his very intercsting contortions. At last I caught sight of the game. They were a large herd of 18 or 20 -some rubbing the bark from the branches-others performing their morning toilet, licking their dark-brown, glossy jackets, and combing 
them with their noble antlers. All appeared unconscious of the approach of their most deadly foes, save one noble bull, the leader of the herd. He seemed suspicious-with head erect, eyes darting in every direction, ears wagging to and fro, and nostril expanded, he snuffed. the breeze. Upon this splendid creature the Indian kept his eye, never venturing to move, save when the head of the Cariboo was turned away. 'Inch by inch we approached the tree. Oh! the agony of suspense I suffered in those few minutes!

"At length we reached our shelter. No time was lost. Howard signed to me to single out a Cariboo, while he took the noble leader, which was about 100 yards distant-the Indian reserving his fire. We stationed ourselves each side of the tree, and our rifles exploded almost at the same moment. Springing to see the effect of my shot, I was pulled down by the Indian; what was my astonishment to see the bull Howard had fired at, stamping the snow and gazing around, with fire and rage in his eye, in search of his hidden enemy. As I looked at his formidable antlers, his majestic height, and great strength-a thought of our helpless situation crossed my mind. The Indian now rested his gun quietly on the tree, and took a long, steady aim-the cap alone exploded with a sharp crack! Quick as lightning the bull discovered our ambush, and with a loud snort made directly for us. Defence or retreat against such a foe, in our situation, up to the waist 
in snow, was almost impossible. In another bound the antlers of the enraged beast wonld hare been in my side, when our gallant little dog dashed forward and seized the bull by the muzzle. Sabatisie and IIoward were busily employed putting on their snow-shoes; and I endeavored to do the same, but with little success. The dog had luckily checked the beast, but he was no match for the enormous strength and wonderful activity of his adversary. Tossing his head, the Cariboo beat the poor little fellow on the snow and against the tree, till I thonght every bone was broken. Finding this of no arail, the bull reared, and with his fore-legs dealt such a shower of quick and powerful blows, that I expected to see the dog drop every minute. While the Cariboo was in this position, the Indian approached him behind and endeavored to hamstring him. But the eye of the bull was too quick; wheeling like lightning, he made a rush at Sabatisie which must have been serions, but was aroided by his falling flat on his face, the Cariboo passing over him and wounding his back. Meanwhile Howard had loaded, but his rifle having become wet, he could not discharge it. The violent exertions of the Cariboo had by this time broke the hold of the dog, and the furious beast now turned to the prostrate Indian -but before he could reach his prey, the dog was again at his head, checking, but not stopping his mad career. Sabatisie on his knee received the shock, and at the moment grasping the bull by the antlers, brought him 
down; when Howard sprung forward and plunged his knife to the hilt in the breast of the Cariboo. With a last mighty effort, the noble creature dashed the Indian in the air, and the next moment his own strong limbs were quivering in death.

"From the commencement of this burst, I confess, I was a little agitated-so much so, that I had not coolness sufficient to tie on my snow-shoes, or load my rifle; but let not any blame me until they themselves have had" the pleasure of being placed in the same delicate situation, up to the waist in snow, and one of those emperors of the deer tribe dancing round.in mad fury, threatening instant annihilation. On examination, we found Howard's ball had taken effect just behind the shoulder, and would have caused death in a short time.

" 'Hillo! old boy, are you hurt?' said Tom Howard, seeing the Indian still on his back.

" 'Cariboo sartain bery strong', grunted the poor fellow. His back was much lacerated. 'Brother cut some gum, and soon be well,' said Sabatisie.

"Howard gathered some balsam formed by the sap running from the bark of the fir-tree, and spreading it on a piece of his handkerchief, formed a strong adhesive plaster-staunehing the blood, he placed it on the wound.

" And now, Meadows, what has become of your game-think he is hit?'

" ' Yes, by Jove, I'll bet my rifle to a pop-gun he is- 
for see, Billy has settled down on his track, and is in chase.

"'On with your snow-shoes, and away! - the track with the blood will be plain as a van wagon-if you come up with the Cariboo, do not fire unless you are sure to kill. I must stop and see if the Indian is much hurt, and swab out my rifle-but I will soon overtake - you-away now!'

"So urged, I started off, and found large drops of blood on the track the prime little dog had taken. As I proceeded, I saw the strides of the Cariboo were shorter, and he had been down sereral times. As I pressed on, in great hopes of overtaking the game before Howard came up, I observed the Cariboo had made for the valley, and after a sharp walk of an hour, I came to the stream, which was open. Here I lost the track, but saw the marks of the dog down the stream-these I followed, and soon heard the baying of the dog. As I proceeded, the river was every moment more rapid. After a sharp turn the stream was compressed between two huge cliffs, and rushed down a water-gap, forming a cascade of nearly one hundred feet. To the very verge of the fall the river was open; but over the fall itself there was a thin coating of transparent ice, which clung to the perpendisular cliffs on each side of the narrow gap, forming a gauze-like veil. The towering cliffs around were covered with a frosting of ice; and from the stunted pines which clung to the barren rock, hung myriads of fantastic 
icicles. At the foot of the fall, the blue water rushed out, dashing the white foam many feet in the air; and through the thick woods which overhung the cascade, the sun cast his rays upon the gorgeous prospect, making every object throw forth a thousand brilliant shades, and the glittering ice which encircled the fall was so transparent, that the blue water could be seen beneath dashing furiously down, as if enraged at restraint. Not ten feet from the verge of the fall, on a rock in the centre of the river, stood the wounded Cariboo. The water around him was fearfully rapid-one false step would carry him under the ice, and down the fall. On the bank stood the dog: my first care was to secure him, as he appeared ready every instant to make a spring that must have been fatal. The Cariboo had chosen a most admirable place of retreat; nothing living could approach him with safety. On each side the perpendicular cliffs towered many feet over his head-before him the roaring torrent, and behind the ice-bound cataract. After feasting my eyes on this wild and romantic scene, I approached as near the fall as the rugged cliff would permit. The Cariboo saw me, and with glaring eye-balls he shook his branching antlers in impotent rage, presenting to my rifle his broad front, as in defiance. I am not ashamed to say I was happy when I glanced at the rapid water and rugged cliff between me and my devoted prey; for I have no doubt, had it been in his power he would have soon shortened the distance 
vetween us-and after what I had so lately witnessed, I had no ver's great desire (seeing I was not as yet a perfect harlequin on snow-shoes, to play the same game orer again with my friend on the rock. To put an end to his wishes and my tears, I presented. My ball took effect directly in his brain, and he quietly dropped into the stream, learing me master of the ficll. The next moment I could see, through the transparent ice, his glossy hide gliding down the cascade."

Amiable reader, thus it was that "Meadows" slew his first Cariboo; and thus, pray for me, that I may kill mine, or ere a year be flown. If I do, believe me, I will try to tell you how I did it, as well-better I may not tell you-as Meadows. Aud so, until next month, fare you $\pi \mathrm{ell}$ ! 



\section{II.}

\section{FEBRUARY.}

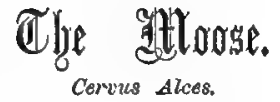

NORTHERN WILDERNESS, BEYOND THE OTTAWA; NEWFOUNDLAND TO NEW YORK.

$-$

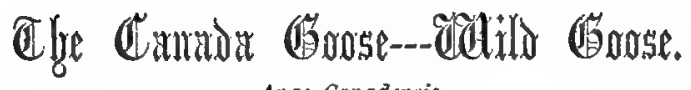

Anas Cunadensis.

NORTH AMERICA, ARCTIC REGIONS, MOUTHS OF THE MISSISSIPPI. 




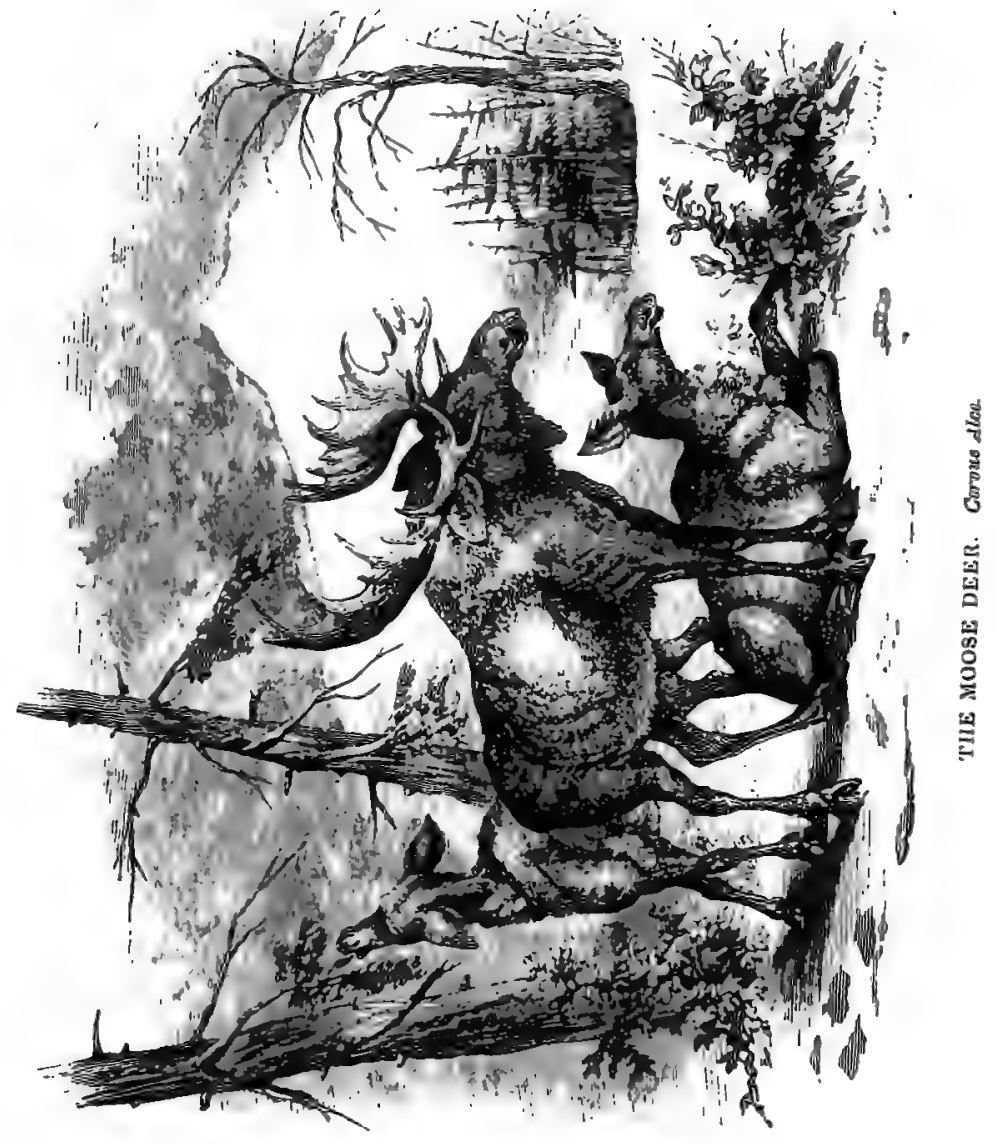




\section{THE MOOSE DEER.}

\section{Cervus Alces.}

THs gigantic deer, the largest of all the deer tribe, and which is distinguished from all others not only by the magnificence of its dimensions, but by the fact that it is the only one of the genus which is uncouth in its form, ungraceful in its attitudes, and awkward and ungainly in its action and gait, is identical in erer'y respect with the Elk of Europe, no distinction being discernible on the closest examination. It must, however, on no account be confounded with the great Wapiti Deer, or American Elk, Cirrus Canandensis, as it is in every respect different and distinct. The Moose-deer, which derives its name in the rernacular from its appellation in the Algonquin tongue, musu, is entirely a Northern, and more especially a North-Eastern animal, being most abundant in the British Provinces of Nova Scotia and New Brunswick, in Maine, the northern part of New Hampshire, and the Adirondack Highlands of the state of New York, beyond which to the westward it is never found south of the St. Lawrence, nor I think is there any rcason to believe that its range has ever extended far to 
the west of this limit or southward to the Atlantic coast. In Lower Canada, on both sides of the St. Lawrence below Quebec, and on the north side so far as to Montreal, it is exceedingly abundant, but to the westward of that city it is rarely if ever found south of the great Ottawa river. A single Moose was killed during the summer of 1849 by an Ojibwa. Indian on the Severn river, which debouches into the north side of the great Georgian Bay of Lake Huron, the skull of which I saw myself, and it was asserted by the Indians generally, that none of the race had been killed within the last fifty years, at nearly which distance of time it was a traditional belief that one had been killed, a straggler, in the same vicinity. To the northward of this they roam as far toward the pole as the forest region extends, the Moose being, as we shall see when we come to speak of his structure and habits, as much adapted to the forest, as is the American Elk, or Wapiti, Cervus Canadensis, to the prairie.

The original limits of these two great deer would seem to have been originally almost identical as to their frontiers, the one beginning exactly where the other ceases to exist, and the one being as remarkably a western as the other is an eastern animal. The Elk was found originally from the western regions of Pennsylvania, if not throughout all the inland portions of that state, through all the intermediate states, a little way back from the sea-board, of Virginia, Kentucky, and 
Tennessee, in all of 'which it has now ceased to exist, to the great prairie states of the west and the foot of the Rocky Mountains, in many of which it is still found frequently, although it cannot be said to abound until you pass the Mississippi and even go beyond the cross timbers. Why this deer ever received the title of Cireves Canadensis, it is difficult to state, as I find no indication of its ever having existed in Canada, but I fancy it has arisen from a mistaken application of the French term Orignal, or Elk, to this animal, which is beyond doubt really applicable to the Moose, that, animal being, in fact, as I have observed, the Elk of Europe, and having the flat palmated horns of that species, whereas the Wapiti has the round branching antlers of the red deer of Europe, Cervus Elaphus, to which animal it bears a very strong analogy, and except in its vast superiority of size, closely resembles.

The Moose is the largest of all the deer tribe, an old bull standing full eighteen hands high at the shoulder, or six feet common measure, while the cows do not fall short of fourteen or fifteen. The fore-legs of this deer are very disproportionately long as compared to the hind legs, and the shoulder stands so much higher than the rump, that at a casual glance you would suppose the animal to be standing up hill. His neck is so short and cumbrous that he cannot graze on the ground without much difficulty, straddling his fore-legs very wide apart, and even then gathering his food from a plain surface 
with great difficulty and even pain; he is not, however, a grazing animal by nature, though he may resort to it at times, from whim or for the lack of other means of subsistence, but essentially a browser, for which mode of feeding he is particularly adapted, being in a lesser degree of the same structure with the cameleopard, althongh the latter is loftier and far more exaggerated in the height of his foreparts, owing to the immense altitude of the trees-a species of mimosa-which afford his favorite nourishment. Further than this, the huge, flexible, prehensile upper lip of the Moose, which he uses nearly as an elephant does his trunk, is of great service to him in collecting the leaves and tender twigs of the birch and alder, which, with the tips of some of the evergreens, are his choice dainties. In the summer season, when the woods are alive with Pharaoh's plague of flies and musquitoes, which seem to derote themselves with particular assiduity to the tormenting this great giant of the wilderness, he delights to resort to marshy pools 'and lakelets, where he wades out till his head is barely above the surface, and lies there wallowing delicionsly all day long in the pure cold waters, safe from his winged persecutors, and browses in security on the floating leaves and buds of the water-lilies and on the aquatic grasses which he crops as he swims or wades about at his pleasure.

The horns, for antlers they cannot correctly be called, of the male are an enormous and apparently useless 
apparatus, for the bull Moose fights principally with his huge, deeply-cloren houfs, which he handles with great dexterity, and with which he can inflict very heavy blows. They often weigh from fifty-six to sixty pounds the pair, and present a flat palmated surface, intersected upwardly by irregular ribs or ridges, each terminating in a short snag or rounded point, one of which is added every year until they attain their full stature. The weight of these is enormous, and accordingly when the auimal runs, which he does at a heavy, awkward, shambling trot, he thrusts his nose high into the air, with his short, sturdy neck pointed upward, so that the horus are rested in some degree upon the back, partly it may be supposed for the purpose of support, and partly to aroid entanglement among the branches and thick-set stems of the cedar-swamps which they most frequent. These horns they shed annually in the spring of the year, and annually renew, the surface being corered with a soft relvet-like fungus, while they are young and tender, and gaining hardness and consistency till in the rutting season, which occurs in the latter summer and early antumn, they are perfect in size and formidable as weapons of offence. At this period the bulls may be heard roaring and bellowing thronghout the mountain gorges of the ranges which they frequent, in the evening especially, and in the early gray of dawn, and when they hear the lowing of the cows they come crashing through the forests with fierce and amorous heat; and if two rival 
sultans meet in the presence of a single sultana, woe to the weaker, for he must needs go to the wall after a desperate conflict, fought out, as if by the knights of old, in the presence of the queen of love if not of beauty, whose caresses are to be the reward of the victor.

Of this propensity foresters take advantage in the season, by imitating the call of the cow Moose, which is easily done by blowing a peculiar note through a common cows-horn, the end of which is partially immersed in water, or on a trumpet made of birch or alder bark for this very purpose by the Indians, who are great adepts at its use, and rarely fail to.extract a reply from the bulls; and ultimately to lure him up within a few feet of the circle of hemlock or cedar-boughs among which they await his coming full of amorous fury and proud defiance, with the ready gun, which soon levels his branched honors in the dust.

It not unfrequently happens that two bull Moose will be attracted by the same call, will bellow their responses to it through the echoing ravines and gorges, and will finally tear down through the rent and crashing underwood, and meeting with a roar of defiance do battle at outrance in the presence of the ambushed enemy, who watches for his advantage at every instant of the fray, and rarely fails to bring down both of the competitors for an imaginary fair one, by a cowardly and ignoble triumph. And a magnificent spectacle it must be to witness, alone and unassisted in the depths of the pri- 
meval forest, in the gray and silvery moonlight, or in the purple dawn of autumnal morning, the fierce and noisy jousting of two of these great forest champions.

There is another mode of pursuing these great deer during the summer season, when they wade into the deep waters to eschew the myriads of flies, which is spoken of with rapture by those who have enjoyed itthat is, to make the wilderness your home, your hemlockbed and bark-roofed camp your dwelling-place, and with canoe, and rod, and rifle, stealthily to paddle along the winding water-courses, lreeping as much as possible within the shadows of the shore, and under the protection of the overhanging branches, when you can often teal up within easy gun-shot and bring them down with one well-directed bullet. The liberty, the independence, the rapturous excitement of this sort of life is entirely indescribable; the delight with which you sleep in the free, fresh, odoriferous air of the forest, with your soft, elastic hemlock-bed-sure preventive of all rheumatic pains-beneath you, and the blue vault, with all its diamond stars above you; the zest with which you enjoy the meal of fresh trout from the river, or sweet digestible wild meat from the woods, the fruits of your own prowess; the health, the.strength, the energy of mind and body which you earn by your rugged toil, and rude though savory food; the perfect sense of hardihood and self-reliance, which you derive from thus owing every thing that ministers to your enjoyment, to your 
own skill and manhood; then, with the splendor of the American antumn weather, and the gorgeous woodland scenes which you must penetrate, these alone would pay you for your toils; cares there are none in the woods, nor anxieties, nor ailings, nor sorrows-for these, with the ringing of door-bells at unseasonable hours, and the advent of matutinal duns, not to be satisfied save with the uttermost farthing, these are the growth of cities, and the tormenters of the civilized and cockney gentleman, unknown to the forest, and set at easy defiance by its hardy, happy inhabitant. Oh! give to others who will it, the luxuries of city life, the costly banquets, the rich wines, the fascinations of women, the maddening excitement of play, the "venerem, et plumas, et conam Sardanapali," but give me my hemlock shanty for my palace, my hemlock-bed for my couch of down, my rifle for my mistress, and my trusty Indian for my comrade and my guide; and, winter or summer, scorching sun or deep-piled snow, the wilderness, give me the wilderness. "The life in the woods for me."

When winter sets in cold and stern, then it is not the Moose's paradise-rather it is his anti-paradise, and the winter of his discontent made glorious summer to his adversaries, who then hug hope to run him down by their strength of wind and limb, and to conquer him by open force and no unmanly fraud or base deceptions.

Well aware that he cannot travel safely or feed easily and plentifully, when his goings to and fro are converted 
into painful flounderings through deep snow-drifts, or yet more painful plungings and breakings through the surfice crusted with glassy ice, when the trees on which to browse are few and far between, no sooner do the first snows begin to fall that the Moose resort to one of two plans, each equally ingenious and equally adapted to the nature of the ground for which they are intended. If a bull intends wintering by himself, as sometimes occurs, wherefore we know not; he seeks out some hill, and crosses and recrosses it a hundred times from summit to base, and from base to summit, and then girdles it with a hundred of parallels, intersecting the perpendiculars, all of slowly macte and deeply trodden foot-paths, trampled down and beaten again, after each fresh succeeding snow-fall, till the whole snowy hill is cut up and checkered into a net-work of firm, hard-trotted paths, along which he can travel at whatever pace he lists, whether lazily lounge along to browse on the succulent shoots, or pounding away at his hard swinging trot, with his wide-spread hoofs crackling at every track, in tull flight from his pursuers, at a rate of eight or nine miles an hour, with the advantage still of feeding as he goes, snatching a juicy morsel from every farorite bush as he dashes along.

When the Moose adopts this mode of wintering, unless the party of hunters is sufficiently strong to post a number of persons on different stands along the Moose-paths to intercept him as he tracks their labyrinthine ways, it 
avails little or nothing to attempt him; for having many miles of hard-trodden paths on which to run, while his pursuers cannot follow them on account of their narrowness, but must blunder along their sides on snow-shoes, with little or no chance of tracking him, since the paths are so hard as to receive no impress from his hoofs, he will keep on running, a half-mile or so ahead of pursuers, without hurrying himself beyond his need till he shall worry out the strongest hunter, and so escape shot-free.

The more usual method, however, for them to winter, is by yarding, as it is termed, or collecting into small bands or droves of greater or smaller numbers, but consisting in general of one old bull, two or three younger males, three or four cows, and the calves of several years accompanying their dams-for it is not usual for the young to quit the cows until they are two or three years old-and then forming yards, or large spaces, well and regularly trampled down so as to be sunk between walls of snow several feet in height, containing within their area trees and shrubs enough to afford ample pasture for the herd during the whole continuance of the cold weather, and from these they never stir until the return of soft spring-time and the melting of the snows.

It may be well here to state, that, in the opinion of many of the best naturalists and foresters of this country, the two habits, alluded to above, as pathmaking and yarding, are in truth accidental matters, and 
the fortuitous result of circumstances, rather than any peculiarities of instinct or sagacity in the animals to which they are ascribed.

These persons contend that the net-work of paths, after the manner described above, intersecting and checkering whole mountain-sides, are naturally produced by the roving perambulations of the great deer; and are not made by him, with any design of future fucilities in obtaining forage, but simply in the course of present search for it.

Farther, they declare that the yards are not formed, or even used, as a temporary winter habitation, from which the animals do not wander during the continuance of cold weather; but attribute their occurrence merely to the unaroidable stamping to and of a family, or a small herd, of these noble cervines, over the snowy surface of some spot which has casually attracted them by the abundance of succulent fond offered by its underwood; and that they quit such places, from time to time, in their ordinary rambles; and entirely, for another and better place, so soon as its supplies are exhausted. This, I regard, the truer and more philosophic riew.

These yards are carefully hunted out by the Canadian Indians, and the tidings are brought into the garrison towns, and received with a perfect burst of enthnsiasm by the officers of her majesty's regiments quartered there, and having little to relieve the monotony of winter, except curling or tandem-driving, unless when a chance of a Moose-hunt raises a gay alarum. 
Rifles are hunted up, and bullets run, snow-shoes are buckled on, and the green-horns excite great sport for the old stagers, by kicking their own shins, and tumbling on their own noses at every second stride. Blankets, and baskets of provision, not forgetting the ammunition, the spirit-flasks, the tobacco-pipes, and the tea-kettle, are packed upon the tobogins, or Indian sledges, made of light wood, to be drawn by the red-hunters through the open forests, and then away for the wild, broad, boundless snow-clad wilderness - the hard tramp by day, the blazing camp-fire, the leafy bed, the fragrant pipe, and the flowing bowl at nigist, and the sleep as sound and as warm beside the roaring pyre, with an untented heaven above, and a temperature 40 clegrees. below you, as though it were taken in a silken chamber, pillowed on down and canopied with velvet.

And now the yard is reached, and one, or perhaps two deliberate and murderous shots are fired, and then away through the treacherous snow-drifts, away over the deceitful ice-crusts flounder the huge beasts at their speed in mortal terror. Away, hard on their traces, flying on fleet snow-shoes, follow the impetuous and shouting hunter's.

Sometimes for days that headlong chase endures, the weary beasts and worn-out men, lying up or encamping, perhaps not a quarter of a mile asunder, when light fails them and they can run no longer, and with the break of dawn renewing the wild career for life or death, for de- 
feat or ignominious glory. That is no sport for boys or striplings, but hard work for strong, stout-hearted men. But the science and the pluck of man prevails in the end; one by one the beasts are overhauled, the heaviest first and the weakest, a rifle-shot, and a shrill "whowhoop" announces the fall of the forest king-a slash of the keen knife steeps the snow with his life-lblood, and away, away, over the crackling crust, with the keen winter's wind warming itself against your face, and your heart thrilling with a rapture unknown to the laggard lounger's of city sidewalks, unsuspected by the sordid and selfish voluptuary.

Such, friends, is the winter Moose-hunt of the Canadian wilderness. Try it, friends, once, and my life on it, each succeeding winter will find you rifle in hand, and snow-shoe on foot, in the interminable forest northward of Quebec, stretching thence on unbroken to the Arctic seas-for verily it is the king of American field-sports. 


\section{THE CANÁDA GOOSE.}

\section{Anas.Canadensis.}

THIS is the bird known universally throughout this continent, as the Wild-Goose, and yet, although that is not in truth his correct apellation, we do not in this instance very particularly demur to it; since it is by very far the most important of all the species of this genus, which visit our shores. The term Wild-Goose is properly applied to the Gray Lag Goose of Europe, which is beyond any doubt the stock whence is derived the common domestic goose of our barn-yards, and which precisely resembles the tame bird, with the exception that the ganders do not become white among the wild fowl; on this, however, no distinction of origin can be supported; for it is well understood that one of the consequences of domestication, is that in the process of generations it converts animals, which are unicolored in their natural state, to piebalds, dapples, and various new colors, in their artificial condition.

The true name of this bird is the Canada Goose; a title which was given to it under the impression that ita 


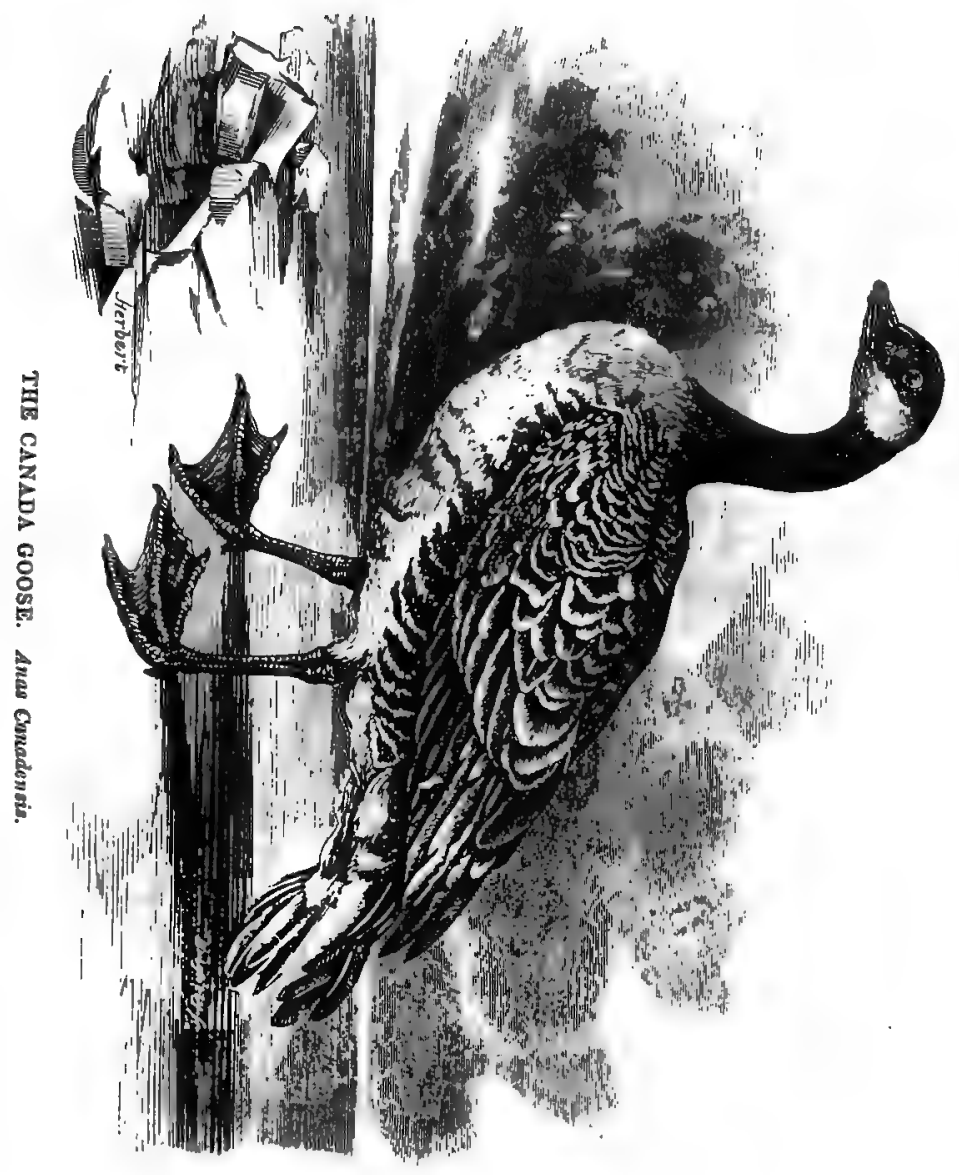



breeding-grounds lay in that country, and in the vicinity of the Great Lakes. Since the period, however, when those provinces have become more thickly settled, more observation has been bestowed on the haunts, habits, and migrations of birds; and it is now well ascertained that, although a few stragglers may breed in various sequestered spots both in the States and in the Canadas, all the main hordes proceed still northward beyond the utmost habitations of man, beyond the limits of the Arctic Circle, perhaps beyond the Pole itself, there to nestle and rear the young in the untrodden solitudes, where no breath of humanity has ever polluted the pure air, amid the brief but delicious summer of the polar regions, where they rejoice- to quote the eloquent words of $\mathrm{Mr}$. Giraud, in his birds of Long Island-where they rejoice in "the absence of that great destroyer, rain, while the splendors of a perpetual dry May render such regions the most suitable to their purpose."

The Canada Goose, though rare, is not unknown in Northern Europe, or eren in England, where it is very frequently domesticated as an ornament on artificial lakes, within the bounds of parks and pleasure-grounds. In unusually severe winters, it is sometimes killed on the sea-coasts and on the inland lakes of Scotland, and the north-eastern parts of England, though not in such numbers as to constitute it an object of regular pursuit. Nor is its flesh there considered a luxury, whether that from change of climate and diet, it really becomes rank 
and unpalatable, or that whim and fashion in this case rule the roast.

Certain it is that, here, it is one of our best sea-shore wild fowl, me judice the very best; for its flesh is succulent and juicy, never rank or fishy, not even sedgy, and, when hung long enough in frosty weather, as tender as the tenderest, even in the old ganders, which many persons consider an abomination.

The breeding-grounds of the Canada Goose, have never as yet been, and probably never will be ascertained otherwise than negatively, as they lie, doubtless, beyond the reach of man's all-daring footstep, there being no point however northerly, to which the bold discoverers of the highiest latitudes have penetrated, at which the Goose has not been observed still wending his way northward, ever northward. "They were seen by Hearne," says Wilson, in his American Ornithology, "within the Arctic Circle, and were then pursuing their way still farther north. Captain Phipps speaks of seeing Wild Geese feeding at the water's edge on the dreary coast of Spitzbergen, in lat. $80^{\circ} 27^{\prime}$. It is highly probable that they extend their migrations to the Pole itself, amid the silent desolations of unknown countries, shut out since the creation to the prying eye of man by everlasting and instperable barriers of ice."

Throughout the United States and the British provinces from the Straits of Bellisle and the Gut of Canso eastward, to the Osage river westward; the biennial migra- 
tions of the Canada Goose are well known to all observant inhabitants; and at the close of autumn and the opening of the spring, their vast phalauxes are seen wending southward and northward, with the regularity of the seasons themselves, cleaving the snow-laden and misty air with the circular sweep of their heavy pinions, and opposing to the currents of the atmosphere the arrowy point of their wedge-like formations, while the hoarse "honk" of the leading gander, answered again from the rear of the battalia, calls the attention of us groveling earthlings to their immeasurable march, steadily sweeping onwards thousands of yards above our pigmy heads.

Of their spring flight, as they return from the mouths of the Mississippi, from the great unfrozen lakes and bayous of the southwest to their far northern homes, thus eloquently sung their own appropriate poet laureat, the well-beloved and long-lamented sportsman bard, known wheresoever the staunch dog is followed, and the true trigger drawn, as J. Cypress, Jr.

"They come, they tear the yielding air with pennon fierce and strong; On clonds they leap from deep to deep, the vaulted skies along ;

Heaven's light horse, in a column of attack upon the pole.

Was ever seen on ocean green, or nnder the blue sky,

Such disciplinel battalia as the cohort in your eye ?

Around her ancient axis let old Terra proudly roll,

But the rushing flight that's in your sight, is that shall wake your sonl. 
" Hawnk! honk ! and for'ard to the nor'ard, is the trumpet tone, What Goose can lag, or feather flag, or break the goodly cone Hawnk ! onward to the cool blue lakes where lie our safe love-bowers; No stop, no drop of ocean brine, near stool or hassock hoary, Our traveling watchword is "our mates, our gaslings and our glory!" , Symsonia and Labrador for us are crowned with flowers, And not a breast on wave shall rest, until that heaven is ours.

Hawnk ! Hawnk ! E-e Hawnk!"

And this, but with the smallest tincture of poetical extravagance and license, is a fair and correct picture of their vernal northward march; for although they do in truth pay us of the midland seaboards a short visit so soon as our sea bays are clear of ice, and do occasionally "stop," and at great peril to themselves, "drop by stool or hassock hoary," still their spring sojourn with us is of short duration. Early in April they collect themselves in vast flocks, soar skyward, and breaking into wedge-shaped phalanxes, headed by the strongest ganders, which are hourly relieved by their comrades, so that each of the males in his turn takes his share of arduous toil of breasting foremost the resistance of the atmosphere, and opening the path for his followers.

Little stint they of force, little stay make they, unless for necessary food and rest by night, or when bewildered by dense fogs and unable therefore to steer northward, more truly than the needle to the pole, until they reach the northern shores of Lake Huron and the waters of the Great Georgian Bay, where they remain for some time, longer or shorter, according to the state of the 
season, and the gradual disappearance of the ice, affording, meantime, sport and subsistence to the Indians, who paddle stealthily upon them in their birch canoes, or shoot them from bough-houses constructed on points which command their farorite feeding grounds in the rice lakes and flats around the mouths of the Northern, the Wye, the Severn, and their neighboring affluents.

Thence, so soon as the ice disappears, they are up and away, and are no more seen by the eyes of man, except as they sweep across the marshy plains about the dispersed and distant forts of the fur cornpanies, until in October, they recommence their earlier voyagings, now journeying southward with recruited strength and augmented numbers, for now each noisy gander and his mate are accompanied by two full-grown and full-feathered goslings, and tarrying scarcely for a moment on the great lakes, or in the inland waters, until they reach their favorite autumal haunts in the great south bay of Long Island, and all along the inlets and lagoons of the Jersey shore, Squam Beach, and Barnegat, and the two Egg Harbors, where they disport themselves, and revel in the sheltered waters, and grow fat on the broad, tender leaves of the sea-cabbage, a common marine plant which grows about the stones and shells on the seabeaches, and on the roots of the sedges, which they are constantly seen in the act of tearing up, and occasionally make excursions to the inlets on the beach for sand and gravel, until these inland bays are frozen over solidly 
with continuous ice, forbidding them to obtain their food, and compelling them yet once again to take wing and fly more southward yet, to where no frost nor north-east tempest cometh.

During this visit it is that they afford the most sport to the gunner, and that they are harassed, especially about Long Island, by every poacher's device and artifice which can be devised to slay them, fairly or unfairly, by man, wholly without consideration, and reckless that the slaughter on their very feeding grounds is fast banishing them from regions where, with all their watchful sentries out and on the alert, they are decimated hourly by volleys from unseen and unsuspected foes.

The worst, most murderous, and least sportsmanly of all these artifices is "the battery," an engine long but vainly proscribed and prohibited by the New York Legislatures, but still in use in all the Long Island waters, though the shrewder, if not more honest or less poaching Jerseymen, tolerate it not in their lagoons and inlets, which still swarm with the fowl daily seen less and less in the Long Island bays.

"The battery," says a good writer in the Spirit of the Times, "is formed of a deal box, about seven feet long, three wide, and two deep ; from the rim of this a platform of board runs off at right angles, about six feet on every side, and the interior is caulked to render it water tight. This is moored on some shoal where the birds are observed to be in the habit of resorting, and bal- 
lasted with stones until the platform merely floats upon the surface of the water; this flat surface is then lightly. covered with sedge, so that at a very short distance nothing but a small quantity of apparently floating weed is discernible."

Into this destructive machine, having arranged his carved and painted wooden decoys, or "stools," around it, the gumner descends with his guns, and lying flat on his back, awaits, from before the first glimmer of dawn, the arrival of the Geese on their feeding grounds, which he butcher's by scores or even hundreds, while they are floating here and there feeding unsuspicionsly. When it is considered that on every shoal on which fowl can feed throughout the Lorig Island waters, two or three of these murderous contrivances are anchored, so that the fowl can never feed in quiet-and at no other period are fowl so jealous of disturbance as while feedingand that they are, moreover, constantly harassed at the same delicate period by being shot at from sailing-boats, running down among them before the wind, before they are aware, it is no wonder that they should rise high into the air, and deserting these inhospitable purlieus, seek safer places, where, if they be shot at fiercely, and compelled to run the gauntlet of innumerable fires, as they fly to and fro from beach to feeding-ground, and from feeding-ground to beach, they are at least allowed to feed in peace and withorit molestation.

The mode practiced in the Jersey waters is this, and 
it is not liable to the objections brought against the former mode, while it affords sport sufficient to glut the greediest sportsman, who shoots for sport, not for pot or market.

Niches are cut in the mud-banks, or points, across which the fowl fly from the beach to the feeding-grounds, and vice versa; into these niches the Egg Harbor skiffs, which the gunners use, are backed up, and in these, their decks plentifully strewed with sedges, clad himself in dingy sedge-colored raiment, the fowler lies, with lis heavy guns expectant. His decoys are moored in the water around him, and as they bob up and dowi with the bobbing of the tide, they closely resemble a real flock of fowl riding at anchor in the shallows.

Here, so soon as the saffron tints of morning begin to steal upon the gray of the eastern sky, the hoarse honk! of the gander reaches the latent gunrer's ear-his quick eye glances to the windward, and faint and far on the bright dawning back-ground he discerns, dimly pen ciled, the form of the anxiously desired wedge.

"Aw-unk! aw-unk!" he sets up aloud the well-simulated cry, crouching down closer in his sedge-covered egg-shell, and cocks his two ponderous single-barrelled duck guns. "Aw-unlk! aw-unk!" the leading gander answers-" Aw-unk! E-e-awnk!"

Near by they come and nearer; now he can mark the circular sweep of their vast oary pinions, and now they spy the stools, and now they stoop toward them-then 
paruse and hover, half suspicious-they are alarmed, they seem about to turn. Oh! most exciting instant.

"Aw-unk! aw-unk!" E-e-awnk!" That admirable mimicry has now succeeded. They are decided-they wheel-stoop-now-now-he can see their very eyes. Up goes the heary gun, and the loud roar, that harbingers the flight of five oz. of $\mathrm{BB}$, is as the knell to the leading gander, and three that fly the next behind him. Up starts the ambushed enemy, seizes his second piece, sights it almost by instinct, and the flash and the roar are simultaneous-and, "By Heaven! it snows Geese!" as I once heard old Jesse shout at Barnegat, on a day when, with a trusty comrade, we slew us twenty Geese, and well on to a hundred Black Duck, Scaup, and Brent Geese. If this be not sport enough for spontsmen, why, then, turn poacher, most ungentle reader, and earn the malediction of all who love a fair field and fair play for all things, whether they be fish, flesh, or fowl..

Here is a brief description of our bird. Look to the wood-cut at the head of this paper, and see if you discern his "very form and body," if not his "age and pressure." Length of bill, from the corner of the mouth to the end, two inches and three-sixteenths; length of tarsi, two inches seven-eighths; length from point of bill to end of tail, about forty inches; wing, eighteen inches. Head and greater portion of neck, black; cheeks and throat, white. Adult, with the head, greater part of neck, primaries, rump and taiI, black; back and wings, 
brown, margined with paler brown; lower part of neck, breast, and belly, whitish-gray; flanks, darker gray; cheeks and throat, upper and under tail-coverts, white; the plumage of the female rather cluller.

Such, reader, is our Canada Goose, or American Wild Goose, a game, bold bird in air and on water, a grand bird on the board. Mine may it be, in both capacities, to meet him soon and often, but especially at sunrise, from the lee of some sheltered hassock to be greeted with his resonant "Aw-unk! E-e-aw-unk!" 


\section{III.}

\section{MARCF.}

\section{The âtuallary. \\ Anas Coschas.}

EUROPE; ASIA; CANADA; UNITED STATE?.

\section{The Amerticar couliongent.}

Anas Americana.

HUDSON'S BAY; CANADA; ATLANTIC COASTS. 




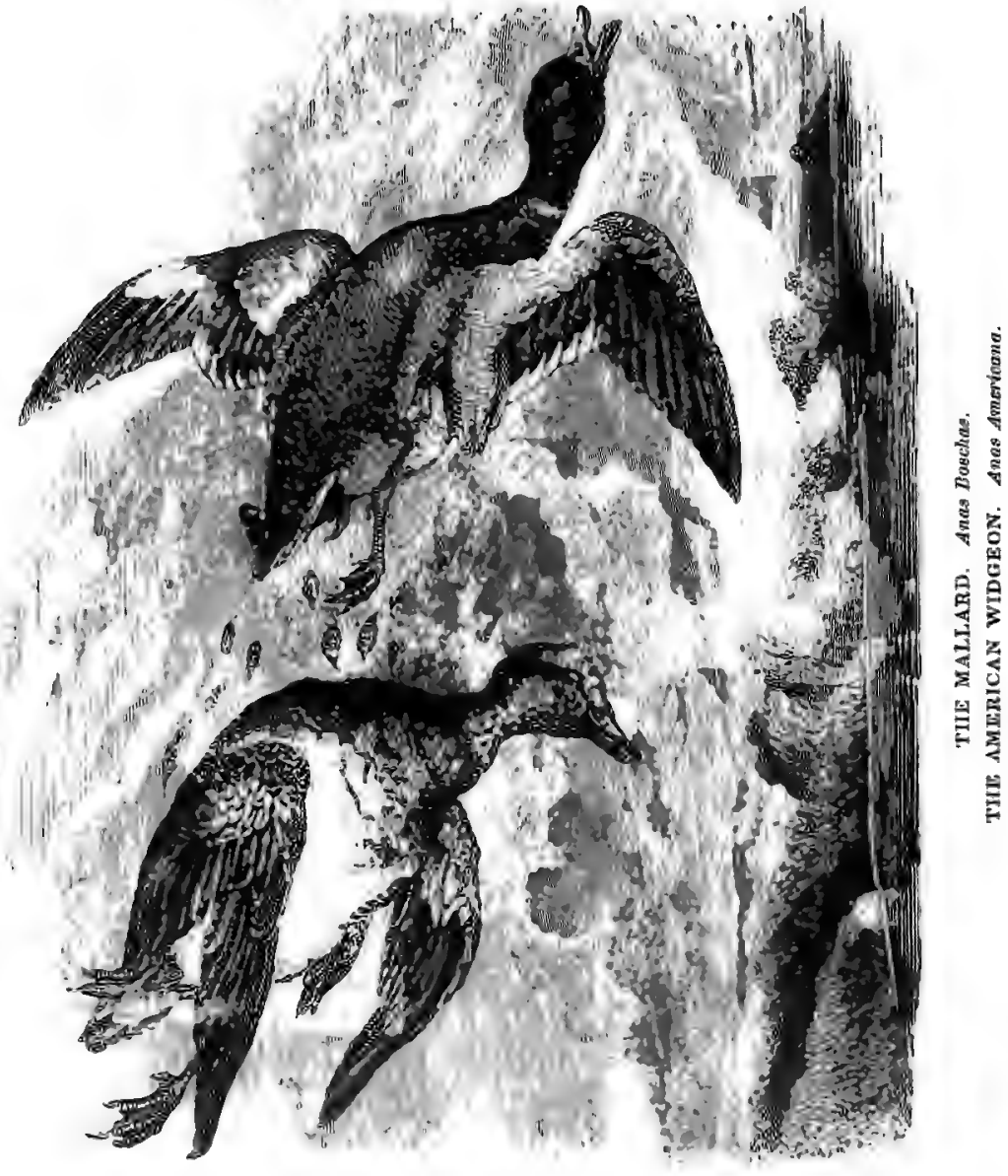




\section{THE MALLARD.}

Anas Boschas.

\section{THE AMERICAN WIDGEON.}

Anas Americana.

Bотн these beautiful ducks, perhaps, with the exception of the lovely Summer Duck, or Wood Duck, Anas Sponsa, the most beautiful of all the tribe, are along the seaboard of the Northern States somewhat rare of occurrence, being for the most part' fresh-water species, and when driven by stress of weather, and the freezing over of the inland lakes and rivers which they frequent, repairing to the estuaries and land-locked lagoons of the Southern coasts and rivers, as well as to the tepid pools and warm sources of Florida, the Carolinas, Georgia, Alabama and Louisiana, in all of which states they swarm during the summer months.

On many of the inland streams and pools of New York, New Jersey, Pennsylvania and the Far West in general, including all the bays, shallows and tributaries of the Great Lakes, as well as all the lovely smaller lakes of New York, especially where the wild-rice, or 
wild oat, zizania aquatica, is plentiful, they are found in very great numbers, especially in the spring and summer time, nor are they unfrequently killed on the snipegrounds of New Jersey, around Chatham, Pine-brook, and the Parcippany meadows on the beautiful Passaic, and on the yet more extensive grounds on the Seneca and Cayuga outlets, in the vicinity of Montezuma Salina, and the salt regions of New York.

In the shallows of the lake and river St. Clair, above Detroit, on the Rivière aux Canards, and the marshes of Chatham in Canada East, all along the shores of Lake Erie on the Canadian side, especially about Long Point, and in the Grand River, they literally swarm; while in all the rivers, and shallow rice-lakes on the northern shores of Lake Huron, which are the breeding-places of their countless tribes, they are found, from the breaking up of the ice to the sliutting up of the bays and coves in which they feed, in numbers absolutely numberless.

The Mallard is generally believed to be the parent and progenitor of the domestic duck, which, although far superior in beauty of plumage and grace of form and deportment, it very closely resembles; yet when or where it was domesticated, is a question entirely dark and never to be settled. It is certain that the domestic duck was unknown to the Greeks and Romans, so late as to the Christian era, although the paintings in the Egyptian tombs demonstrate beyond a peradventure that it was familiar to that wonderful people from a very 
remote period; and it is also known to have been among the Chinese, who rear and cultivate them to a very great extent. Indeed, it is, I think, in the highest degree probable that the duck, in its domestic state, is an importation into Europe from the East, where, as I believe in ever'y quarter of the globe, the Mallard is a common and indigenous native of the fresh waters.

The Mallard, or Wild Drake, commonly known in the Eastern States as the Green-head, westward as the Gray Duck, and in Alabama as the English Duck, weighs from thirty-six to forty ounces, and measures twentythree inches in length, by thirty-fire in breadth.

The bill is of a yellowish-green color, not very flat, about an inch broad, and two and a half long from the corners of the mouth to the tip of the nail; the head and npper half of the neck are of a deep, glossy, changeable green, terminated in the middle of the neck by a white collar, with which it is nearly encircled; the lower parts of the neck, breast and shoulders are of a deep, vinous chestnut; the covering scapular feathers are of a kind of silvery white, those underneatl rufons, and both are prettily crossed with small, waved threads of brown. Wing coverts ash, quills brown, and between these interrenes the specutum, or beauty-spot, common in the duck tribe, which crosses the wing in a transverse, oblique direction. It is of a rich, glossy purple, with violet or green reflections, and bordered by a double streak of sooty black and pure white. The belly is of a 
pale gray, delicately crossed and pencilled with numberless narrow, waved, dusky lines, which on the sides and long feathers. that cover the thighs are more strongly and distinctly marked. The upper and under tail coverts, lower part of the back and rump, are black, the latter glossed with green; the four middle tail feathers are also black, with purple reflections, and, like those of the domestic duck, are stiffly curled upward. The rest are sharp-pointed, and fade off to the exterior edges from brown to dull white. -Iris of the eye bright yellow, feet, legs and webs reddish orange, claws black.

The female, and young male until after the first moult, are very different in plumage from the adult drake, partaking none of its beauties, with the exception of the spot on the wings. All the other parts are plain brown, marked with black, the centre of every feather being dark and fading to the edges. She makes her nest, lays her eggs-from ten to sixteen in number, of a greenish white-generally in the most sequestered mosses or bogs, far from the haunts of man, and hidden from his sight among reeds and rushes. To her young, helpless, unfledged family, and they are nearly three months before they can $\mathrm{fly}$, she is a fond, attentive and watchful parent, carrying or leading them from one pool to another, as her fears or inclinations direct her, and she is known to nse the same wily stratagems, in order to mislead the sportsman and his dog, as those resorted to by the ruffed 
grouse, the quail and the woodcock, feigning lameness, and fluttering as if helplessly wounded, along the surface of the water until she has lured the enemy afar from her skulking and terrified progeny.

The Mallard is rarely or never shot to decoys, or stools as they are termed, since these are but little used except on the coast, where this duck is, as I have previously observed, of rare occurrence, although it is occasionally found in company with the Dusky Duck, anas obscura, better known to gunners as the Black Duck.

It is stated, however, by Dr. Lewis, in his clever work entitled "Hints to Sportsmen," that, "like most of wild fowl, the Mallard breeds in the far north, and makes its appearance in the antumn, among the first of our ducks. It is common throughout all our rivers and fresh-water lakes, but is seldom met with on the sea-coast. As the winter progresses, large numbers continue south, and take up their abode among the rice-fields of the Carolinas, where they become very fat and particularly palatable; their flesh at all times when the weather is not severe is goö, as they feed on vegetable matter in preference to any other kind of food, and only partake of flesh when they cannot obtain anything else.

"Mallards are easily brought within gunshot by means of decoys used in the way already described under the head of Canvass Backs. They are numerous at times on the Delaware, and numbers are killed by shooters hiding themselves in boats and in the reeds 
within range of their stool ducks, which are set out on the edge of the reeds. They are fond of the seeds of the wild oats that flourish so profusely on the flats of the Delaware, and their flesh soon becomes delicate and juicy."

Of this statement I doubt not the correctness, although what I have written above is founded on my personal observation, having shot wild fowl in the United States only on the Long Island and New Jersey shores, or the inland rivers of the Atlantic coasts, and on the great lakes, where decoy ducks cannot readily be procured.

In England and on the continent of Europe Mallards are netted in great numbers in decoy ponds fabricated for that purpose, a full account of which, with plans, will be found in Beurich's British Birds, vol. ii.; but as this method is not adopted in the United States, it is needless further to allude tó it.

"Like the Dusky Duck," says Mr. Giraud, in his very clever and agreeable manual on the birds of Long Island, "when pursued by the sportsman, it becomes shy, and feeds at night, dozing away the day out of gun-shot from the shore.

"Early in the month of July, 1837, while hunting over the meadows for smaller game, I came upon a pair of Mallard Ducks, moving slowly down the celebrated 'Brick-house creek.' The thought occurred to me that they were a pair of tame ducks that had become tired of the monotony of domestic life, and determined on 
pushing their fortunes in the broad bay. As I advanced they took wing, which undeceived me, and I brought them down. They proved to be an adult male and female. From this circumstance I was led to suppose that they had bred in the neighborhood. I made a diligent search, and offered a sufficient bounty to induce others to search with me-but neither nest nor young could be found.' Probably when migrating, they were shot at and so badly wounded as to be unable to perform their fatiguing journey, perhaps miles apart, and perchance only found companions in each other a short time before I shot them."

When the young birds are about three-fourths grown, and not as yet fully fleclged or able to fly strongly, at which age they are termed flappers, they afford excellent sport over water-spaniels, when they are abundant in large reed beids along the brink of ponds and rivers. When full grown, moreover, when they frequent parts of the country where the streams are narrow and winding, great sport can be had with them at times, by walking about twenty yards wide of the brink and as many in advance of an attendant, who should follow all the windings of the water and flush the birds, which springing wide of him will so be brought within easy range of the gun.

The Mallard is wonderfully quick-sighted and sharp of learing, so that it is exceedingly difficult to stalk him from the shore. especially by a person coming down 
wind upon him, so much so that the acuteness of his senses has given rise to a general idea that he can detect danger to windward by means of his olfactory nerves. This is, however, disproved by the observations of that excellent sportsman and pleasant writer, John Colquhoun of Luss, as recorded in that capital work, "The Moor and the Loch," who declares decidedly, that although ducks on the feed constantly detect an enemy crawling down upon them from the windward, will constantly, when he is lying in wait, silent and still, and properly concealed, sail down upon him perfectly unsuspicious, even when a strong wind is blowing over him full in their nostrils.

For duck shooting, whether it be practiced in this fashion, by stalking them from the shore while feeding in lakelets or rivers, by following the windings of open and rapid streams in severe weather, or in paddling or pushing on them in gunning-skiffs, as is practiced on the Delaware, a peculiar gun is necessary for the perfection of the sport. To my taste, it should be a double-barrel from 33 to 36 inches in length, at the outside, about 10 guage, and ten pounds weight. The strength and weight of the metal should be principally at the breech, which will answer the double purpose of causing it to balance well and of counteracting the call. Such a gun will carry from two to three ounces of No. 4 shot, than which I would never use a larger size for duck, and with that load and an equal measure of very coarse powder- 
Hawker's dncking-powder, manufactured by Curtis and Harvey, is the best in the world, and can be procured of Mr. Brough, in Fulton Street, New York-will do its work satisfactorily and cleanly at sixty yards, or with Eley's green, wire cartridges, which will permit the use of shot one size smaller, at thirty yards farther. The utility of these admirable projectiles can hardly be overrated; next to the copper-cap, of which Starkey's waterproof, central-fire, is the best form, I regard them as the greatest of modern inventions in the art of gunnery.

Such a gun as I describe can be furmished of first-rate quality by Mr. John Krider of Philadelphia, Mr. Joln, or Patrick Mullin of New Iork, or Mr. Henly T. Cooper of the same city, ranging in price, according to finish, from one hundred to one hundred and fifty dollars, of domestic manufacture; and I would strongly recommend sportsmen, requiring such an implement, to apply to one of these excellent and conscientious makers, rather than even to import a London gun, much more than to purchase at a hazard the miserable and dangerous Birmingham trash, mannfactured of three-penny skelp or shamdamn-iron, got up in handsome velvet-lined mahogany cases, and tricked out with varnish and gimcrackery expressly for the American market, such as are offered for sale at every hardware shop in the country.

The selling of such goods ought to be made by law a high misdemeanor, and a fatal accident occurring by 
their explosion should entail on the head of the vender the penalty of wilful murder.

The Mallard is found frequently associating in large plumps with the Pintail, or Sprigtail; another elegant fresh water variety, the Dusky-Duck on fresh waters, the Greenwinged Teal in winter to the southward, and with the Widgeon on the western waters.

On the big and little pieces-two large moist savannas on the Passaic river in New Jersey, formerly famous for their snipe and cock grounds, but now ruined by the ruthless devastations of pot-hunters and poachers-I have shot Mallard, Pintail, and Black Duck, over dead points from setters, out of brakes, in which they were probably preparing to breed, during early snipe-shooting; but nowhere have I ever beheld them in such myriads as in the small rice-lakes on the Severn, the $W_{y e}$, and the cold water rivers debouching into the northern part of Lake Huron, known as the Great Georgian Bay, and on the reed-flats and shallows of Lake St. Clair, in the vicinity of Alganac, and the mouths of the Thames and Chevail Ecarté rivers.

I am satisfied that by using well-made decoys, or stools, and two canoes, one concealed among the rice and reeds, and the other paddling to and fro, to put up the teams of wild fowl and keep them constantly on the move, such sport might be had as can be obtained in no other section of this country, perhaps of the world; and that the pleasure would well repay the sportsman for a 
trip far more difficult and tedious than the facilities afforded by the Erie Railroad and the noble steamers on the lakes now render a visit to those glorious sportinggrounds.

The Amerionn Widgeon, the bird which is represented as falling headforemost with collapsed wings, shot perfectly dead without a struggle, in the accompanying woodcut, while the Mallard goes off safely, quacking at the top of his voice in strange terror, though nearly allied to the European species, is yet perfectly distinct, and peculiar to this continent.

It is thus accurately described by Mr. Giraud, although but an unfrequent visitor of the Long Island bays and shores:

"Bill short, the color light grayish blue; speculum green, banded with black. Under wing coverts white. Adult male with the coral space, sides of the head, under the eye, upper part of the neck and throat brownish white, spotted with black. A broad band of white, commencing at the base of the upper mandible, passing over the crown." It is this mark which has procured the bird its general provincial appellation of "Baldpate." "Behind the eye a broad band of bright green, extending backward on the hind neck about three inches; the feathers on the nape rather long; lower neck and sides of the breast, with a portion of the upper part of the breast reddish brown. Rest of the lower parts white, excepting a patch of black at the base of the tail. Under 
tail covert the same color. Flanks brown, barred with dusky; lower part of the hind neck and fore part of the back undulated with brownish and light brownish red, hind part undulated with grayish white; primaries brown; outer webs of the inner secondaries black, margined with white-inner webs grayish brown; secondary coverts white, tipped with black; speculum brilliant green, formed by the middle secondaries. Length twenty-one inches, wing ten and a half. Female smaller, plumage duller, withont the green markings."

The Widgeon breeds in the extreme north, beyond the reach of the foot of civilized man, in the boundless mosses and morasses, prodigal of food and shelter, of Labrador, and Boothia Felix, and the fur countries, where it spends the brief but ardent summer in the cares of nidification, and the reproduction of its species.

During the spring and autumn, it is widely distributed throughout the Union, from the fresh lakes of the northwest to the shores of the ocean, but it is most abundant, as well as most delicious where the wild rice, Zizania pannicula effusa, the wild celery, Batisneria Americana, and the eel-grass, Zostera Marina, grow most luxuriously. On these it fares luxuriously, and becomes exceedingly fat, and most delicate and succulent eating, being almost entirely a vegetable feeder, and as such, devoid of any fishy or sedgy flavor.

In the spring and autumn it is not unfrequently shot in considerable numbers, from skiffs, on the mud banks 
of the Delaware, in company with Blne-winged Teal; and in winter it congregates in vast flocks, together with Scaups, better known as Bluebills, or Broadbills, Redheads, and Canvasbacks, to which last it is a source of constant annoyance, since being a far less expert diver than the Canvasback, it watches that bird until it rises with the highly-prized root, and flies off with the stolen booty in triumph.

The Widgeon, like the Canvasback, can at times be toled, as it is termed, or lured within gunshot of sportsmen, concealed behind artificial screens of reeds, built along the shore, or behind natural coverings, such as brakes of cripple or reed-beds, by the gambols of dogs taught to play and sport backward and forward along the shore, for the purpose of attracting the curious and fascinated wild fowl within easy shooting distance. And strange to say, so powerful is the attraction that the same flock of ducks has been known to be decoyed into gunshot thrice within the space of a single hour, above forty birds being killed at the three discharges. Scaups, or Blackheads, as they are called on the Chesapealie, tole, it is said, more readily than any other species, and next to these the Canvasbacks and Redheads; the Baldpates being the most cautious and wary of them all, and rarely suffering themselves to be decoyed, except when in company with the Canvasbacks, along with which they swim shoreward carelessly, though withont appearing to notice the dog. 
It has been supposed that Ducks in general, and the Widgeon in particular, are of keen scent; and I am more particularly induced to allude to this from the fact of my finding the following in the work of Dr. Lewis, who is usually so correct, that to point out an error of opinion is in no wise to detract from its credit or utility. "The best weather for this sport"-paddling a punt upon flocks of Widgeon- " is a clear, windy, half moonlight night," says he, "provided the wind does not blow from you, as the ducks may smell you; in fact, it is always necessary to get to leeward of wild fowl of all kinds, as their power of scenting is very great."

That Dr. Lewis should have fallen into this error does not at all surprise me, since it is one prevalent among English gamekeepers, and American gunners and baymen alike.' Such men, who are invariably excellent observers of facts and judges of effects, and on whose advice, not to attempt to advance upon flocks of wild fowl feeding, down wind, either by land or water, it is very well to rely, are for the most part indifferent deducers of causes; and I have rarely found one of either class, on whose judgment concerning the cause of any habit, instinct, migration, or movement, however well established as a fact, the least reliance could be placed. That this alleged fact, of wild fowl having the power of scenting an enemy, is an error, has been distinctly established by that excellent sportsman and judicions 
writer Colquhoun, and my own observation fully confirms his assertion.

Wild fowl will not allow you, it is true, to creep on them over land, or paddle upon them over water, down the wind; but that is because the breeze bears down the sound of your approach to their keen ears, not the taint of your presence to their nostrils. If you are concealed up wind of them, and preserve silence, they fly or swim up to your ambush, perfectly fearless, and unscared by your presence, which-had they any real power of scenting at a distance-their sense of smell would equally reveal to them, whether you were stationary, or in motion.

These birds; with their congeners, are also shot from points, as at Carrol's Island, Abbey Island, Maxwell's Point, Legoe's Point, and other places in the same vicinity about the Bush and Gunpowder rivers, while flying over high in air; and so great is the velocity of their flight when going before the wind, and such the allowance that must be made in shooting ahead of them, that the very best of upland marksmen are said to make very sorry work of it, until they become accustomed to the flight of the wild fowl. They are also shot occasionally in vast numbers at holes in the ice which remain open when the rest of the waters are frozen over; and yet again by means of swivel guns, carrying a pound of shot or over, discharged from the bows of a boat, stealthily paddled into the flocks at dead of night, 
when sleeping in close columns on the surface of the water. This method is, however, much reprobated by sportsmen, and that very justly, as tending beyond any other method to cause the fowl to desert their feeding . grounds.

In conclusion, we earnestly recommend both these beautiful birds to our sporting readers, both as objects of pleasurable pursuit and subjects of first rate feeds. A visit at this season to Seneca Lake, the Montezuma Meadows, or that region, could not fail to yield rare sport. 


\section{IV. \\ APRIL.

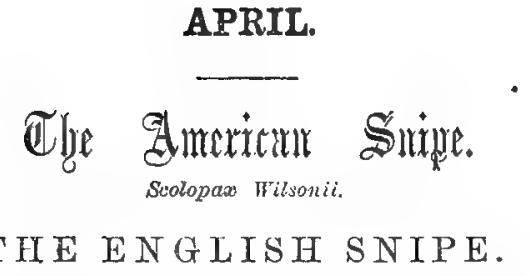

BRITISH PROVINCES; UNITED STATES; ARCTIC REGIONS TO MEXICO.

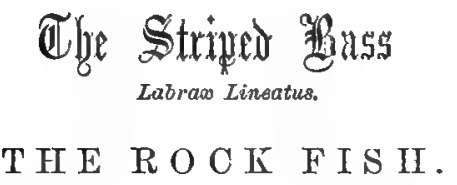

BAY OF FUNDY TO THE CAPES OF THE _HESAPEAKE. 




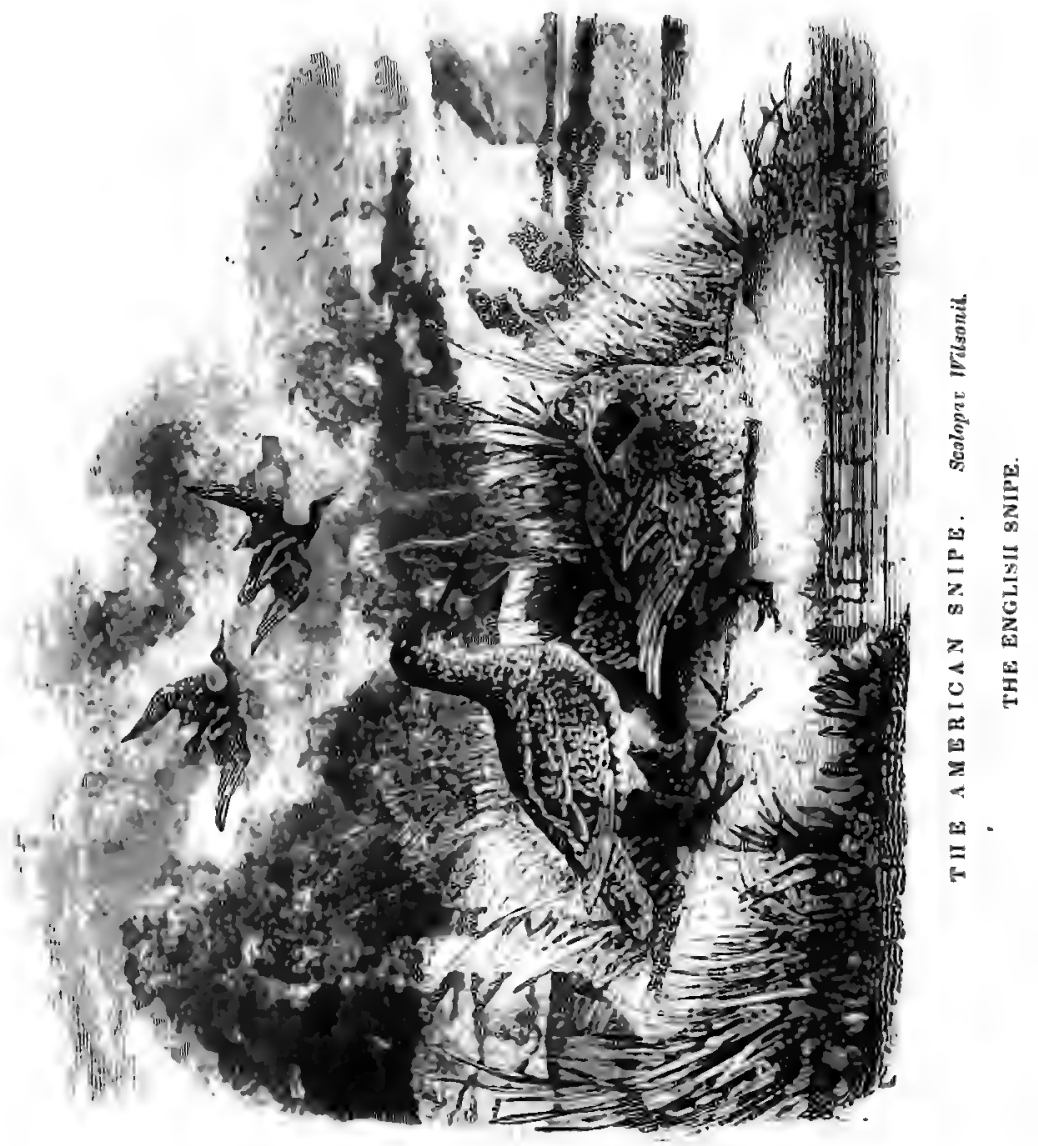




\section{THE AMERICAN SNIPE. Scolopax Wilsonii.}

\section{THE ENGLISH SNIPE.}

Ir is a singular thing, and one which elncidates the great research necessary, and the extreme difficulties ellcountered, in the attempt to establish facts of natural history with regard to birds of passage, that this beautiful little bird, the general favorite of the sportsman and the epicure, well known to all classes of men, and a visitant, in some one of its closely allied varieties, of every known nation, is still a mystery, as regards some of its habits, and continues to baffle the inquiries of the most learned and inquisitive ornithologists.

Its habits, the nature of its food, and therefore the necessities of its existence, render it an inhabitant of temperate climates, and of regions in which the moist and loamy soil, from which it derives its sustenance of small worms, insects, and the like, is not frozen during the period of its visitations so hard as to preclude its boring with its delicate and sensitive bill for its semi-aquatic prey of worms and larvæ. 
Still, as extreme cold prevents it from obtaining subsistence, extreme leat would appear to be still less congenial to its tastes or temperament; for, whereas it lingers in the north until autumnal frosts seal up the marshes and the soft stream margins against its probing bill, it flies from its winter quarters in the rice-fields of Carolina, and Georgia, and the farther morasses of Texas and New Mexico, the instant that opening spring admits of its return to the fresh meadows and pure rivulets of the north-east.

The winter quarters of this bird, then, are fairly ascertained, ranging from Carolina sonth.ward until almost the northern limits of the Tropics; thence, so soon as the blue-bird begins to pipe in the apple-tree, the shad to appear in the rivers, the willow-bads to turn yellow, and the frogs to croak and chirrup, with us to the northward, the snipe is seen everywhere, hurrying, according to the progress of the season, singly, in whisps of ten or twelve, or in huge flights, ever, ever, northwardly. In Maryland, in Delaware, in southern Pennsylvania and New Jersey, he is wont to appear from the 1st to the 20th of March; in New York and New Jersey northward, from the 15th of March to the 20th of April, remaining for a longer or shorter period according to the steadiness of the weather, the state of the ground as regards wet or drought, and the geniality of the season. In mild, soft, temperate, moist seasons, with a prevalence of westerly weather, he will linger with us into the lap of June; and. 
in such seasons, more or less, he woos his mate, nidificates and rears his young among us, from the Raritan and the Passaic northward and castward to the Great Lakes, and throughout Michigan, Wisconsin, probably, and Canada West, up far into the Arctic Circles.

Still, those which breed with ns in the United States, and even in the Canadas, are but as drops of water to an ocean, to those which rush on the untiring pinions moved by amatory instinct to the far breeding grounds of Labrador, Symsonia, and Boothia Felix, whither it is supposed they resort to rear their young in hyperborean solitude, thence to reissue, in the summer and the earlier autumn, and re-populate our midland meadows.

In the neighborhood of Amherstberg, Canada West, they appear very early; often in February of mild seatsons, always in Marcb; and there may breed, and remain until banished by severe cold. I shot one there myself last zutumn, the last bird of the season, very late in November, I believe on the 28 th or 29 th ; and with the plover, the Hudsorian godwit, and the Esquimaux curlew, they were seen there this spring in the first days of March.

Around Quebec, I have shot English snipe on the uplands, in fallow fields and rushy pastures-for the grass in the morasses does not begin to shoot in those far northern latitudes, so as to afford them shelter, until much later in the year-in the end of April and the beginning of May; but they arrive there only by small scattered 
whisps, or single birds, tarry a few short days, and flit onward to their unknown destination.

This, then, is their mystery-that in no known land are they perennial; in no ascertained region-so far as I can learn-are they positively known to breed in the vast concourses which must breed somewhere, in order to supply the prodigious flights which issue yearly from the northern regions of three continents, Europe, America, and Asia, to fill the warmer countries, and to be slaughtered literally by myriads, season after season, without undergoing much if any visible diminution of numbers.

Ever, in all pláces, in all countries, in all continents, which they visit in spring, they are seen pressing northward still, from March until May; no one being able to say here ends their tide of emigration, this is their chosen resting-place.

Their breeding season is from the middle of May to the beginning of July; on the 4 th of which month I have shot young birds, with the pin-feathers undeveloped, as large as the parents-these birds having been hatched on the ground whereon I killed them. Indeed, it is my opinion, that all birds which tarry in our latitudes beyond the 10th of May, either do breed with us, or would do so but for the persecution of the pot-hunter-all which intend to steer farther north having departed ere that time.

About the 15th of July the returning hordes, young 
birds and old together, full grown and in fine condition, begin to reappear in the marshes of Quebec and its vicinity, which may be said to be the extremest northern point from which we have continuous and authentic annual information of their appearance. At that time the slaughter of the snipe on the marshes of Chateau Richer, and of the islands farther down the St. Lawrence, is prodigious. There they linger until the frosts become so severe as to drive them from their feeding-grounds, which generally takes place early in September, from which time, throughout that month, all October, and a portion-more or less according to the season-of November, and even December, every likely swamp, morass, and feeding-ground of Canada West, of the western, midland, and eastern states, from which they are not persecuted and banished by the incessant banging of pot-hunters and idle village boys, swarms with them, in quantities sufficient to afford sport to hundreds, and a delicacy io thousands of our inhabitants, if they were protected from useless and unmeaning persecution, by which alone they are prevented from being as numerous among us as at any former period.

For I am well assured, that-unlike the woodcock, which, breeding in our midst, and dwelling with us for months at a time, is annually slaughtered while breeding, hatching, or immature, and is thus in rapid progress towards extirpation-the snipe, when unmolested in its breeding-grounds, is not diminished in its numerical pro- 
duction, but is rendered scarcer in thickly settled-districts, nigh to large towns, by incessant harrassing, which drives it to remoter and securer feeding-grounds.

I do not mean by this, however, to assert that the abolition of spring snipe-shooting would not be an advantage-on the contrary, I am convinced that it would; although well assured that no such measure can be hoped at the hands of our legislators; for, as the snipe ordinarily lays four eggs, the destruction of each one of the breeders on their way northward, of course diminishes the stock of the coming season by five birds.

So much for the times and places of the snipe's migrations. Of his appearance or characteristics-so well is he known-it is almost useless to speak; it may, however, be well to observe that although commonly termed the ENGLise SNIPE, our bird is a thorough native American, differing from the bird of Europe in being about one inch smaller every way, and in having two more feathers, sixteen instead of fourteen, in the tail. In other minute, but still permanent, and therefore characteristic distinctions, it differs from the Asiatic and Antarctic snipes; although in their rapid, zigzag flight and shrill squeak when flushed; in their irregular soaring througl the air in gloomy weather; in their perpendicular towering and plumb descent, their drumming with the wing-feathers, and bleating with the voice, during the breeding-season, all the species or varieties so closely resemble each other, that they are far more easily con- 
founded than distinguished by the unscientific sports. man.

The American bird has, however, two or three habits, during early spring-shooting, which I have never observed in the European species, nor seen noticed in any work of natural history ; the first of these is frequenting underwood and bushy covert abounding in springs and intersected by cattle-tracks, and occasionally even high woods, during wild, stormy, and dark weather, especially when snow-squalls are driving; and this is a habit of the -bird meriting the attention of the sportsman, as in such weather, when he finds no birds on the open and unsheltered marshes, he will do well to beat the neighboring underwoods, if any; and if not, the nearest swampy woodlands; by doing which he will oftentimes fill his bag when he despairs of any sport. The second habit is that of alighting, not unfrequently, on rail-fences, or stumps, and even on high trees, which I think I can safely assert that the European bird never does; and the third is the utterance, when in the act of skimming over the meadows, after soaring, bleating, and drumming for an hour at a stretch in mid air, of "a sharp reiterated chatter, consisting of a quick, jarring repetition of the syllables, kek-kek-kek-kek-kek, many times in succession, with a rising and falling inflection, like that of a hen which has just laid an egg." *

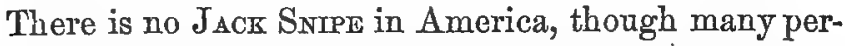

- “Frank Forrester's Field Sports of North America," vol. i. p. 161. 
sons ignorantly and obstinately assert the reverse; the true Jack Snipe being a northern bird of Europer and Asia, visiting the milder climates during the hard weather. It is an exact counterpart of the English Snipe, only about one-half smaller; it never utters any cry on rising, and rarely flies above one hundred yards, often dropping within fifty feet of the muzzle of a gun just discharged at it, although unwounded. The bird which is here confounded with it, is the Pectoral Sandpiper, a bird about one-third smaller than the snipe, of a lighter brown, with a short, arched bill, and a feeble quavering. whistle. It is found indiscriminately on the sea-shore, and in upland marshes; I have shot it from Lake Huron to the Penobscot, and the Capes of the Delaware; it lies well before dogs, which will point it, and is a good bird on the table. It is known in Long Island as the "Meadow Snipe," and the "Short Neck" in New Jersey, and thence westward, as the "Fat Bird," or" "Jack Snipe," indiscriminately. It is not a snipe at all, but a Sandpiper, Tringa Pectoratis.

The only other true snipe ascertained to exist in America, is the Red-Breasted SNIPE, Scolopax Noveboracensis, better known as the "DowrTcher," an unmeaning name, adopted and persevered in by the Baymen, or as the "Quail Snipe." At Egg Harbor the gunners call it " the "Brown-back." It is found only on the salt marshes, and is never hunted with dogs, but shot from anbush over decoys. 
It appears, then, that the coming and stay of the common snipe in our districts, in spring, is very uncertain and dependent on the state and steadiness of the weather. Some seasons, they will stay for weeks on the moist, muddy flats among the young and succulent herbage, growing fat and lazy, lying well to the dog; and affording great sport. Sometimes they will merely alight, feed, rest, and resume their flight, never giving the sportsman a chance even of knowing that they have been, and are gone, except by their chalkings and borings where they have fed. Again, at other seasons, they will lie singly, or in scattered whisps on the uplands, in fallow fields, even among stunted brushwood, lurking pertu all day, and resorting to the marshes by night, leaving the traces of their presence in multitudes, to perplex the sportsman, who, perhaps, beats the ground for them, day after day, only to find that they $\pi$ ere, but are not.

This variance in the habit of the snipe it is, which makes him so hard a bird to kill; for, although he is perplexing from his rapid and twisting flight to a novice, I consider him, to a cool old hand, as easy a bird to hill as any that flies. The snipe invariably rises against or across wind, and in doing so hangs for an instant on the air before he can gather his way; that instant is the time in which to shoot him, and that trick of rising against wind is his bane with the accomplished shot and sportsman, for by beating down the wind, keeping his brace of dogs quartering the ground before him, across the wind, 
so that they will still have the air in their noses, he compels the bird to rise before him, and cross to the right on the left hand, affording him a clear and close shot, instead of whistling straight away up wind, dead ahead of him, exposing the smallest surface to his aim, and frequently getting off without a shot, as it will constantly do, if the shooter beats up wind, even with the best and steadiest dogs in the world. The knack of shooting snipe, as some people who can't do it choose to call it, is no other than the knack of shooting quick, shooting straight, and shooting well ahead of cross shots-this done with a gun that will throw its charge close at forty to fifty yards, with $1 \frac{1}{2}$ oz. of No. 8 shot, equal measures of shot and of Brough's diamond-grain powder, will fetch three snipe out of every five, which is great work, in spite of what the cockneys say, who pick their shots, never firing at a hard bird, or one over twenty paces away, and then boast of killing twenty shots in succession. Verbum sap.

The great difference of the grounds to be beaten in different weathers; the difficulty in determining which ground to assign to which day; the immense extent of country to be traversed, if birds are scarce or wild, or if there are many varieties of soil, covert, and feeding in one range, and the sportsman fail in his two or three first beats in finding game, and therefore have to persevere till he do find them, these, and the hardness of the walking in rotten quagmires and deep morasses, affording no sure foot-hold, and often knee-deep in water, these it is 
which make successful snipe-shooting one of the greatest feats in the art, and the crack snipe-finder and snipeliller-for the two are one, or rather the second depends mainly on the first-one of the first, if not the first artist in the line.

It is from this necessity of beating, oftentimes, very extensire tracts of land before finding birds, and therefore beating very rapidly if you would find birds betimes, that I so greatly prefer and recommend the use of very fast, very highly-bred, and very far-ranging setters, to that of any pointer in the world, for snipe-shooting in the open-apart from their great superiority over the pointer in Lardihood, endurance of cold, poters of retrieving; beauty and good-nature.

Of course, speaking of dogs, whether setter, pointer, dropper, or cocking-spaniel, it is understood that we speak of dogs of equal qualities of nose, staunchness to the point, and steadiness at coming to the charge the instant a shot is fired. No dog which does not do all these things habitually, and of course, is morth the rope that should hang him; and no man is worthy the riame of a shot or a sportsman, who cannot, and does not, keep his dogs, whether setters, pointers, or cockers, under such command that he can turn them to the right or left, bring them to heel, stop them, or down charge them, at two hundred yards distance if it be needful.

If these things, then, be equal, as they can be made equal, though I admit a setter to be more difficultly kept 
in discipline than a pointer-the fastest setter you can get, is the best dog for snipe-shooting; his superiority, in other points, infinitely counterbalancing the greater trouble it requires to break and control him. I am well aware that it has been said, and that by authorities, that the best dog over which to shoot snipe, is an old, slow, broken-down, staunch pointer, who crawls along at a foot's pace, and never misses, overruns, or flushes a bird.

And so, in two cases, he is ; but in one case, no dog is just as good as he is, and in the other the argument is one of incapacity to use what is best, and therefore is no argument.

If birds are so thick on the grounds, and so tame that. you can fill your bag in walking over one or two acres at a foot's pace, a very slow pointer is better than fast setters-but no dog at all, your walking up the birds yourself, which you can do just as quickly as the dog can, is better than the slow pointer. Indeed, on very small grounds, very thickly stocked, it is by far the most killing way to use no dog, but to walk up the birds.

If a man is so weak and infirm of purpose, or so ignorant of the first principles of his art, as to be unable to control his setters, he must, I suppose, use a slow pointer; but it cannot matter what dog such a man uses, he never can be a sportsman.

If there be a hundred birds lying, and lying well on one acre of feeding-ground, the birds can be killed with- 
out a dog, or with a slow dog, as you will; any man who can pull a trigger must fill his bag.

If there be a hundred birds scattered, wild, over five hundred acres of ground, where are you with your slow dog; or your no dog? Just no where. While you are painfully picking up your three or four birds with your slow pointer, your true sportsman, and slashing walker, with his racing up-head and down-stern setters, will have found fifty, and bagged twenty-five or thirty.

There are ten days in a season when birds are wild and sparse, for one when they are congregated and lie hard; and the argument comes to this, that when birds can be killed with ease, even without a dog at all, a slow pointer is the best; when they are difficult to find, and hard to kill, even by a orack shot, the slow pointer is no where, and of no use, while the racing setters will fill the bag to a certainty.

For my own part, I can say to a certainty, that I have had more sport, and killed more birds, by many; many times, when birds have been widely scattered, and diffcult to find, and when I have walked half or a quarter of a mile between every shot fired, than I ever have when birds have lain close, and jumped up at every pace under my feet; and for a simple reason, that the places in which birds so rise and lie, are rare and of small extent, and the days on which they do so few and far apart.

Therefore I say, friend-for all true sportsmen I hold friends-choose well thy day, when the air is soft and 
genial, the wind south-westerly, the meadows green with succulent and tender grasses, and moist with the deposit of subsiding waters - select thy grounds carefully; in such a time as I have named, the wide and open marsh meadows; but if the wind be from the eastward, cold, squally and snow laden, then try the bushy, briery brakes, where cattle poach the soil, and the marsh waters creep, or the verge of the meadows, under the lea of the maple swamp, or at the worst the very gronnds where you would beat for woodcock in July-begin from the farthest windward point of thy beat, casting thy brace of setters off from thy heel, to the right and left, and so often as they have diverged one hundred yards, turning them with a whistle and a wave of the hand, so that they shall cross continually before thy face, down wind of thee, at some thirty paces distant; and so persevere-if birds be plenty and lie well, walking not to exceed two miles the hour; if they be rare and wild, four miles, or by'r lady! fire, if thou mayest compass it. If one dog stand, while the other's back is turned, whistle, that he shall turn his head, then hold thy hand aloft, with one quiet "toho!" but no shouting; if he be broke, he shall stand like a carved stone. Then walk up to the point leisurely, be sure that thou go down wind, making a circuit if needs be, with thy gun at half-cock, the ball of thy thumb on the hammer, and the nail of thy fore-finger inside the guard, but not upon the trigger. When the bird rises, cock your gun, and down him! If thy dogs do their devoir, they shall 
drop to the charge unbidden; if they do not, raise thy hand with an imperious gesture, and cry coolly and calmly, "Down charge!" but howerer ill they behare, nay, even if they run in and eat thy bird, more not till thy gun is loaded; then calmly walk up to them, drag them, pitilessly scourging them all the way, to the place where they should have charged, and rate them in the best of thy dog-language. I say "scourging them pitilevely," because that is in truth the merciful course; for so one or two whippings will suffice, instead of constant small chistisements and irritation, which spoil a dog's temper and break his spirit, without conquering his obstinacy, or gaining the ascenduncy orer him.

It, on the contrary, they charge as decent dogs should and do charge, so soon as thy gun be loaded, lift them, with a "Hold up, good lads!" and cast them gently onward, checking them with a "Steady, dogs!" if they show disposition to be rash, until they point the dead bird, if killed, or draw on him, if running. Then, with a "Toho! Steady!" walk to their point; pick up the bird nnder their noses, praising them the while, or bid them "Fetch!" according to the circumstances of the case; but if they retrieve the bird without pointing him, or even after pointing him, until told to "fetch," let chas. tisement not hide her head.

This, rest assured, friend, is the way to do it.

For the rest, whether thou wear fen-boots, or shoes and trowsers, or, as I nse, by deliberate preference, arch- 
boots, corduroy shorts, and leggins, snit thine own fancy; but let thy shooting-jackot be roomy on the chest and shoulders, and well supplied with ample pockets. Let thy gun be-for my choice-of 31 inches, 12 or 14 guage, $7 \frac{3}{4}$ to 8 pounds. , Let thy powder be Brough's diamond grain, ov John Hall's glass-on no account any otherthou mayest get it of Henry T. Cooper, in Broadway, New York-thy shot, No. 8-thy caps Starkey's central fire, or Moore \& Gray's, or Westley Richards'-by no means French, or Walker's, the first of which fly, while the latter are, I think, corrosive. Forget not to have in thy pocket a dog-whip, a stout knife, a yard or two of strong cord, a pocket-flask, replenished, as thou wilt, with old Otard, or as I recommend thee, Ferintosh or Glenlivat whiskey-stick in the seam of thy waistcoat a strong darning-needle, headed with sealing-wax, it is the only true and responsible gun-picker; and so, good sport to thee, and health and temper to enjoy it!--as good sport, gentle reader, as I trust myself to enjoy this coming week of April, the rain-gods and the river-gods permitting, and the nymphs remembering us, as their long time adorer, in their kind orisons.

The American SrIPe, established by Wilson as a distinct species, is eleven inches long, bill inclusive, and seventeen from tip to tip. Bill fluted, two and a half inches long, the upper mandible the longest, terminating in a highly sensitive nob, brown, tipped with black. The crown of the head black, bisected lengthwise and bor- 
dered by three yellowish-white streaks. Above the eye a dusky-brown line; neck and upper breast, pale dusky brown, speckled with black and white; chin dirty white. Back black, bordered with two white lines. Scapulars velvety black, richly marbled with ferruginous, and broadly edged exteriorly with white. Wings dusky, all the feathers tipped with white, quills brown, exterior quills odged with white. Upper tail coverts, ferruginous, tipped with whitish and spotted with black. Tail black, ended with a chestnut bar, tipped with white. Belly pure white; flanks white with dusky bars. Thighs, vent, and under-tail coverts white. Legs and feet pale green.

It is worthy of remark that the American Snipe, though neither webbed nor semipalmated, swims freely, a fact which is, I believe, mentioned by no naturalist.

On the first occasion which made me acquainted with this fact, I was standing on the verge of a narrow brook, of some six or eight feet over, in the act of loading both barrels of my gun, which I had just discharged, when a snipe flushed by another of my party, flew over my head, and pitched on an open spot of muddy soil, within six feet of me, evidently not observing me, as I stood motionless. I watched its actions and movements, for a few seconds, as it pruned its ruffled feathers, walked daintily about, picked up a worm or two, and finally, to my great surprise, took to the water, swam cleverly across the brook and ensconced itself in a tuft of rushes, whence I shortly afterward dislodged and shot it. 
On the second occasion, I was shooting on the Chatham meadows, in company with $\mathrm{Mr}$. Nicholls, late of H. M. 82d Reg't. The birds were wild, the day windy, and the ground too wet for birds to lie well. At last we marked three down together in a small meadow, bordered by a very broad fen ditch of eighteen or twenty feet, and half that depth with clean cut banks, nearly perpendicular. There was nearly no covert on the meadow.

Our setters drew up carefully-stood perfectly dead when we saw them drop, looked wildly about for a moment, much puzzled at seeing nothing rise, then drew on slowly and foot by foot, to the edge of the broad dyke, where they again stood steadily. When we reached the bank, the three birds rose, out of shot, in the bare marsh beyond. In all they had run about three hundred yards, besides swimming the brook. Previous to seeing that, I should have fancied the birds had taken wing, and beaten no further than to the watercourse. Now I should certainly cross it, and try, before abandoning the game, whether the dogs could not make them out on the farther bank.

To this, I annex an account of a veritable day's sport, which occurred precisely as it is here set down, to the smallest incident, to the author, while shooting over a superb brace of setters, purchased of that well known sportsman, "Dinks" of Amherstburgh, in company with a crack" shot and boon companion, now departed. 
The scene was Short's Landing, in the State of Delaware, and on the noble river of the same name. The place "Robinson's tavern"-- the time daybreak, on as wild an April morning as ever wolke in mingled hailsqualls and sunshine.

\section{SPRING SNIPE-SILOTING.}

"If you please, sir, it's taime to get oop," said a cheerful voice, with a most marvelous north-country burr, at the best bed-room door of a small way-side tavern, in the little State of Delaware, not many miles distant from the noble river whence it derives its name.

"The dence it is !" replied the lodger, in fine manly ringing tones, although the speaker was but just awakened. "I did not think that I had been in bed ten minutes. What time is it, Timothy, and how does the day look?"

"T" clock's run doon; and it beant day," replied Harry Archer's famous body servant, who was in one of his literal moods, that morning, busying himself, as he spoke, in stropping his master's razors by the apology for a light afforded by the home-made dip.

"Confound you, man, when will it be day then, and how does the morning frame g"* answered his master,

"To "frame," in Yorkshire, signifies " to promise," " to give token of becoming," as "the puppy frames to be a good one." "The day frames to be fine." 
himself adopting the Yorkshire phraseology, half in fun, half in irritation, to meet his henchman's comprehension.

" $T$ " sun'll be oop iv half an hoor, and t'morn frames vary badly."

"What--is it wet? are we going to have a rainy day?" "Nay! it's not that weet; nor it beant going to ra-ain, ay reckon. But it blaws raight doon, and t' sky's as red as blude amaist i' t' east. It'll tak' walking the day, and shuting too, if think'st to mak' a bag."

"Easterly wind, Tim?"

"Norwest," answered the varlet. "Noo, then, t' razors is ready and $t$ ' hot wather; and t' breakfast, sooch as ' $t$ is, it'll ready i' faive minutes. T' other gentleman, he's been doon i' t' kitchen, boiling t' eggs hard mair nor a quarter of an hoor."

"Hurrah! then, away with you; and tell him I'll be with him before they are hard."

Nor was the boast an empty one, or unfulfilled, for scarcely ten minutes had elapsed, before the rickety staircase clattered beneath the ponderous hob-nailed half-boots of the sportsman, and while his companion was still superintending the preparation of the eggs which were to furnish their luncheon, Harry entered the breakfast room in full fig, corduroy breeches, leather leggins, broad-skirted, many-pocketed shooting coat, and wide-leaved felt hat.

"The top of the morning to you, Charley;" said he, 
as he came in, addressing the Baltimorean, who was booted to the hip, ready for action.

"The bottom of the night, rather ;" replied Charley laughing. "It's an awful state of society, when a fellow's dragged out of bed by an insane Yorkshireman, two hours before day-break, and made to get into his boots, whether or no."

"It must have been something of a job to get into yours, I should think; but I'll tell you what, if 'we get the birds into a bit of tussocky bog, where we shall find them, if we find them anywhere to-day, you'll get out of them, I fancy, a plaguy deal quicker than you got in; for they'll stick fast as sure as mud's mud-and the mud there, or clay, rather, is better than any boot-jack."

"The Lord's will be done-" answered the other; "at all events, I shall keep dry ten minutes longer than you."

"True, O king! Now, Timothy, take half that loaf of rye bread, cut it into chunks, and give the dogs their breakfast."

"Which dogs are you going to take to-day, Harry?" " 'Dinks' and 'Bob'-the orange and white, and the black and white Russian."

"Dinks is the greatest beauty and Bob the greatest brute I ever set my eyes upon."

"If you don't change your tune before night, you may eat me. Any one can see that Dinks is by far the hand- 
somer, but Bob is the very best dog I ever pulled a trigger over in my life. That's all."

"But I thought you said they had never seen snipe."

"I said they had never been hunted upon snipe, or allowed to point them. English-broke setters, are very apt to be whipped off snipe, for it's a horrid bore in moor-shooting, to toil half a mile or better up hill to a steady point, and then instead of a pack of grouse, to flush what Colquhoun calls a 'twiddling snipe.' These dogs were broke in England, and re-broke in Canada West."

\section{"And are there no snipe there?"}

"So many, and they lie so hard, that dogs are useless. On the regular snipe grounds, they walk them up."

"And how do you expect these dogs to point snipe now?"

"I do not expect them to point snipe at first; but as soon as they find we are shooting them, they'll point them fast enough, I promise you."

"You think so?"

"No. I know so. I would bet a hundred to five, if I were a betting man, that before night they point, and back, and find dead ton, on snipe as steadily as ever you saw dogs."

"May be so; but it"s new to me. Do you mean to say that good dogs will stand anything?"

"I mean to say that good dogs can be broke to stand on anything, or-nothing." 
"On anything! on any game you mean."

"I mean, precisely, what I say-on anything. And that is the reason why I checked you for shooting a meadow-lark over them the other day, and why I an so particular as to the 'who' I take out with me. If small birds are killed indiscriminately with game, over dogs, before many days you will have as dead points at larks and brown thrushes, as at quail and ruffed grouse. If a man shoots pigeons, larks, and black-birds, or even reed-birds, for that matter, over my setters, he may do so once, but he will have no second chance, I promise you."

"I expect to see these dogs of yours paragons. They ought to be such, by all the trouble you take with them. I know no one who insists so much on doing every thing. ship shape."

"They are good dogs. The best broke dogs, to my mind, that I have seen in this country; but this is no fair opportunity to judge them. Their forte is high fast ranging for quail ; and they are going to be tried to-day, in ground, and upon game, such as they never have seen. But come; you seem to have finished that abominable coffee, so we had better get under way at once. It is a wild, bad morning, and the birds will scarcely lie; and if we want to make anything like a bag, we shall have to fag hard for it."

Thereupon, without further words, the two friends took up their guns and got under way; Timothy follow- 
ing, game-bag on shoulder and cudgel in hand, the two setters, just released from the chain, gambolling about in the highest spirits and most admirable condition, as was evineed by the moist coolness of their jet-black noses, and the silky gloss of their deeply feathered coats.

"There is a piece of wild meadow here, Charley," said Archer, pointing across a pair of bars to the right, "which, before the banks were broke, and the tide got in, used to be the first in the country for spring shooting. There are a good many birds in it now, I dare say, for it has got plenty of covert, and they will seek covert in such a wind as this."

"Let us try it, then, if you say so."

"It is most infernal walking, but it wont do to stick at trifles. So here goes," and suiting the action to the word, he strode across the fence, and at the first step was mid-leg deep in a soft rust-colored sludge, half semi-liquid mud and half semi-decomposed vegetable matter. A few floundering strides through this Sirbonian bog, brought them to drier, if not sounder ground, which was, in trutb, even harder walking than before, as the soil was here so tenacious that it was difficult to draw the leg out of the mire, into which it sunk ankle deep. In places, this was covered by high reeds, standing wide apart, with splashes of shallow water covering the surface, and here the bottom was harder; in others, a rank, short, rushy grass, which had probably been 
burnt over, some two years before, grew thick and matted on the loose rotten soil, through which, erery few yards asunder, soaked little rills of nearly stagnant water, indicated more by the blackness and ooziness of their muddy channels, than by any risible stream or current.

The setters looked at one another wistfully, and then at their master, as if they wondered what the deuce they were expected to do in such ground as that, and when at length in obedience to his "hold up, good lads!" and the wafture of his hand to the right and left, they broke off, and began to quarter their ground steadily and beautifully, crossing each other in regular diagonal lines; they did not beat at their usual dashing gallop, heads up and sterns down, as they would have done, had they been beating for quail, but felt their way, as it were, gingerly and fearfully, keeping at a trot, though they whipped their flanks all the time with their feathery sterns, and often putting down their noses, as if to seek for some strange trail or scent.

"Upon my life! Harry," said his friend, "if it were not impossible, I should believe that those dogs know as well as we do, that they are after some game to which they are unaccustomed to day."

"Know it! of course they know it! Whr, if re had been upon stubbles, they rould hare ranged the whole of this piece, before this time. Ha! Bob-toho!" he exclaimed, as a snipe sprung directly under the black 
dog's nose, who went on without taking the least notice either to stand or to chase- "Toho!" and at the word, the staunch brutes both came to a stand, irresolute of course, and uncertain, as a stand always must be, when dogs do not know what they are upon, but still, without a forward motion, after the word met their ears. But, even as he shouted, Hairry pitched up his gun to his eje, literally drawing the trigger as it rose, so that it was discharged the instant the butt struck his shoulder-for - the bird had sprung wild, at least twenty yards off, in the first instance, and the wind blowing very fresh, in cold squalls, had gone away, as if 'the devil drove,' directly in the teeth of the north-wester, zigzaging it with all his wings, and reiterating his sharp squeak, as if in triumph. But there was a quick eye, and nimble finger behind, and a gun, that if held straight, was wont to tell a tale; and when he had got some five-and-forty yards away, the strength of the charge struck him full, and sent him, doubled up like a rag, some six yards furtliter forward. At the report, as is very often the case, in snipe shooting, a second bird, which would have skulked and allowed them to pass him, jumped up within three feet of Archer's toe, and wheeling half round him to get the wind, was cut down, completely riddled, before he had flown ten paces. At the cecond shot, the meadow seemed literally alive with birds, some thirty or forty rising one by one, between the young men and the dogs, most of them in front of the Baltimorean, and 
going away, scaipc, scaipe, scaipe, scaipe, as who should say, "dence talie the hindmost," to the north-westward, ever as they flew and squeaked, calling up fresh legions over the wide flat, until there must have been above a hundred snipe in the air at once.

At these, Charley did his work well, keeling a brace over, very neatly, one of which fell within a yard of Bob's nose, who had gone down to charge withont being bidden, the moment the report of the first shot followed the flash. The steady dog snuffed a little, and wagged his tail, but did not stir, though to increase the temptation, the snipe, which was only wing-tipped, after turning some twenty consecutive somersaults under his nose, made sereral ineffectual efforts to rise, springing four or five feet into the air, and screaming "scai $l^{\prime}$," à qui micux.

"Wonderfully steady, indeed!" said Charley, in profound admiration-wonderfully steady. But that was a slashing shot of yours, that first one, Harry."

"Yes! it was some, as Bill Porter would say. I wanted to kill that chap for the dog's sake, and would not have missed him for a trifle. I had no idea there were such a lot of them lying all around us. I nevel saw so many birds on the ground in my life; if it were a still, warm day, we should have rare sport. As it is, we will make out a bag. All this has turned out capitally. I would not be surprised, if you will give me five minutes to work the dogs after my own fashion, to see them stand the next bird, after we hare retrieved these.". 
"Take your own time-I am ready. At all events, I will say now that I never saw better-broke, or steadier dogs."

"Now then, hold up, good lads," cried Harry, waving his hand to the dogs with a low whistle, and walking up to them, he encouraged them, and cheered them, as he made them find each one of the four dead birds, and when found, let them scent and snuffle them as much as they chose, and even mouth them gently. After that, he laid them at a short distance before their noses, and crying "toho !" made them stand and back, several times in succession. After this, he pocketed the birds, apologizing to his friend, as he came up, for having kept him waiting.

"No need for an apology, Harry," said he; "on the contrary, I am much obliged, for, like the dogs, I too have been taking my lesson."

"Well, forward, hold up lads!" and away they went again, the dogs gathering courage as they drew, and beating more boldly and carrying more head, as they ranged forward, but still working much slower, and more warily than they would have done on quail. For a while they found nothing, for all the birds had scattered far and near, at the first disturbance of the feeding ground. After a while, however, at the edge of some tall flags in good springy feeding ground, Bob, who was a little to the right, in front of Charley, dropped from his canter into a slow trot, straightened his neck and 
stern, and drew on in a straight line. "Look ont, there is a bird there!"

Scaipe! scaipe! close under the dog's nose he started, and as he started, but not till then, Bob stood stiff. The bird fell to Charley's shot, was recovered, bagged, and on they went, rejoicing. Five shots and no bird missed.

The next rise was to Archer. Two snap shots, right and left, birds which rose wide of the dogs. The first, fell clean killed-the second, just grazed by the shot, skated off, and pitched three hundred yards off. The dead bird, Dinks pointed dead, in fine style, Bob backing him. And twenty minutes after, the order was reversed, Bob finding the hurt bird, beautifully, and Dinks backing eighty yards off. That bird took another shot, but he came to bag. After that, all day long, the green dogs worked like old hands, on their new game; before afternoon, they were racing heads up and sterns down, in their old fashion, and yet neither of them flushed another bird all that day. Despite wind and weather, the friends filled a heary bag, and as they sipped their peach brandy, by the fireside in the evening; Charley said, laughing :- "Well, Harry Archer, coute qu'il coutc, I will never doubt again, that well-broke dogs can be made to point ancthing, or"-nothing!"

"And, is Bob a brute, now ?"

"Dinks is the beauty, but Bob is the best; and that is 
not saying a little, for, on the whole, they are the very best brace I have ever seen together."

"I thought that you would say so-and you have bad-"

"A right good lesson on dog-breaking, so good night." 



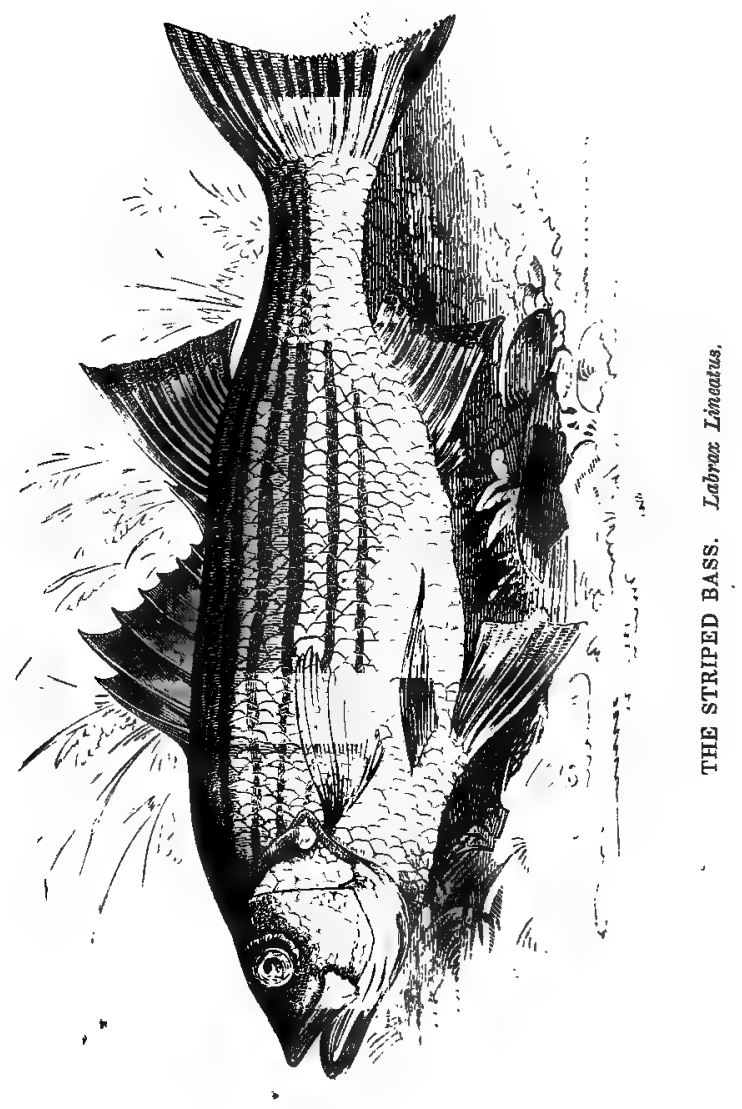




\section{THE STRIPED BASS.}

Labrax Lineatus.

THE ROCK FISH OF TIE DELAWARE AND SOJTHWARD.

Tris noble and sporting fish, which is peculiar to the continent of North America, was first, I believe, distinguished and defined by the late learned Dr. Mitchell, of New Iork, though included by him in the division Perca, in lieu of Labrax, to which it has since been more correctly attributed.

Dr. Smith, in his "Fishes of Massachusetts," has severely censured Dr. Mitchell for his distinguishing this fish, and attaching to it his own name-pronouncing it to "be a common table fish, known from time immemorial all over Europe." Dr. Smith, howeter, not Dr. Mitchell, is the person in error; as the Striped Bass, Labrax Lineatus, is a purely American fish, entirely distinct from the common European Bass, Labrax Lupus, which very rarely leaves the salt water, preferring to spawn in the sea bays, rather than to run up fresh streams or rivers, 
though it is said to have been taken in the Tiber, between the two bridges, by the ancient Romans.*

There is said to be a variety of this fish found in the St. Lawrence, which is described as wanting the regular distinctive lines of the Striped Bass, and is said to assume a more spotty coloring; the spots, however, running in regular lines, five above and five below the lateral line, and somewhat resembling ancient church music, whence it has been named by Lieutenant Colonel Smith, who has done much for Canadian Icthyology, Labrax Notatus. The Striped Bass does not, it appears, run up the St. Lawrence so far as Quebec; at least it is so stated by Dr. Richardson, in his great work on Northern Zoology ; but is commonly found, according to my friend, Mr. Pesley, the accomplished fisherman and historian of those waters, in all the rivers of New Brunswick, which debouche into the Gulf, where they afford fine sport with the large scarlet Ibis fly, used for salmon-trout, with the smelt as a trolling-bait, and with the clam, or a piece of lobster-the latter a bait which I have never known to be used in our waters, though from its similarity to crab, which is in great request here at some seasons, its excellence need not be doubted.

* Histoire des Poissons, cited by Richardsou, Fauna Borcali Americanc. I should, however, entertain some doubt, if the identity of the fish depends merely on the identity of the classic name, Lupus, with the modern name - since the Latin Lupus is equally rendered $P i k e$, which is found in those waters. 
So far southward as the waters of the Chesapeake Bay, they are found in abundance and of large size; and the Falls of the Potomac is a much frequented spot for taking them. It is stated in "The American Angler's Guide," that they are found also in the rivers and bays of Florida. Such may be the case, though I have not heard them named as southern fish, even so far as Charleston Bay, to which Tautog have been recently introduced, by friends of mine from that region of the United States, while I have the sanction of that distinguished Icthyologist, the late Mr. Dunbar, of New Orleans, for believing that few, if any, of our northern species are common to the southern waters, it being his decided opinion that the Sheeps-head of the Gulf is a distinct fish from that of the Atlantic coasts.

The Striped Bass is taken of all sizes, from a few ounces, up to seventy or eighty pounds, which may be set down as his maximum weight. He is of the order Acanthopterygii, or thorny-finned fishes, haring one or more hard bony spines in adrance of each of the soft-rayed fins. Its gill-rays are seven in number; its dorsal fins consist first of eight spines, secoud of one spine, thirteen soft rays; the pectorals of sixteen soft rays; the rentrals of one spine, fire soft rays; the anal of three spines, twelve . soft rays; and the caudal of seventeen rays ; the operculum serrated, suboperculum has two spines, partly concealed by the membranes, no scales on the opercula.

The lateral line of the fish is nearly straight. It is 6 
covered with large scales of a metallic or nacrous lustre, varying from reddish brown, with cærular and greenish reflections on the back, to the brightest silver on the belly. It has eight, or sometimes nine longitudinal lines, the fourth of which corresponds with the lateral line, the first four running through the whole length of the fish, the others becoming fainter and gradually dying away, as they extend towards the tail. He is a severe fish of prey and very voracious, and is accordingly equipped with a very powerful system of teeth, and his tongue is rongh, like a file, with innumerable rows of small thornlike teeth. Of all species, which may properly be called sea-fish, the Striped Bass is, perhaps, that which most affects fresh waters, for at an early season in the spring, so soon as, or almost before they are clear of ice, he begins to run up the rivers in pursuit of the smelt, to which he is a cruel enemy and persecutor, and of the shad, which he follows assiduously to their spawning places, making sad havoc with the roe of the latter.

Either of these, therefore-the smelt or spearling, or any very white and glistening fish, or even a piece of polished pearl or tin as a trolling bait, or in squidding with a hand-line-and the shad roe, potted and salted so as to preserve it, and attached to the hook with a needlefull of yellow silk, as a bottom bait, in rapid scours over gravelly ground, will be found exceedingly fatal baits. It is worthy of remark, however, that except in the spring season; and in rivers up which shad and smelt 
are known to run, or on serf beaches, and in sea bays, it will be worse than useless to use either, especially the latter.

In surfs, striped Bass will take the artificial squid, mistaking it for the Spearling, Athernia Menidia, the Sand-lance, or other small fry on which they feed; and in tide ways, such as Hell-gate and the numerous passages in that vicinity, they are frequently taken in great numbers, and of very large size, with that hideous marine reptile, the living squid.

In the early spring, and in general water, shrimp are probably the most killing bait, shad roe excepted, for rivers frequented by that fish. When crabs begin to shed they may be used indiscriminately with shrimp; the latter to be fished with from one to three feet from the bottom, with a float and light sliding sinker. In the early autumn, crab on the bottom is preferred by many anglers; and in some water the soft clam is very successful; but in swift streams, where the water is fresh, no bait, to my fancy, equals any bright, glittering fish, spearling, minnow, killy-fish, what you will, at the end of a hundred yards of clever trolling-line, with a bottom of good, round single gut, two swivels, a No. 1 Limerick through the tail, and a small perch hook through the lip, and a skilful hand to keep him glancing through the ripples, life-like, till a ten-ponnder strikes him with an arrowy rush, and whistles away some seventy yards of line off your ringing click-reel, before you know what 
you're about-for he is a deuce of a run-away, is your ten-pound Bass, when the barbed hook is in his jaws.

$\mathrm{He}$ has not so much resource as the Salmon, does not often throw himself off the surface water, or strive to fall on the tightened line and break it; neither have I seen him run in often, if ever, upon the angler, or sulk at the bottom. But I think his first rush, if anything, is stronger, and I am sure it is longer, than that of an equal salmon. He will fight hard, for his time; but his time, providing you keep a taught hand on him, make him work for every inch of line, and mind not to let him smash you, either against rocks on the bottom, or against piles or stumps, the neighborhood of which he loves, and around which he is sure to twist you if you let him, will not be so long by twenty minutes, as a ten-pounder Salmon on a fly, well played, with good tackle-without it you have not a chance-and twelve minutes should have him dead-beat, and half-drowned, with the gaff in his glittering sides.

Fly-fishing is not certain for Bass; when they are in the humor to take, however, they give fine sport; and in a fine spring morning, with a dark ruffle on the water, it is worth the while trying. A salmon rod will be required for this sport, with a reel, of course; a single-gut bottom, and any large, gaudy lake-fly; but none is, I think, so killing as that made by the Conroys, especially for the Black Bass of the lakes; Gristes Nigricans, an entirely different fish, peculiar to the St. Lawrence 
basin, but equally killing for this his congener. It has four large wings, two of the Scarlet Ibis, and two of the Silver Pheasant, with a scarlet chenil body. On the St. Lawrence it is sure death.

Of squidding at night with hand-lines as thick as your little finger, and a live squid of a pound's weight at the end of it, I speak not; for, although in the Harlem River, in little Hell-gate, and about Hog Island, the fifty and sixty pounders are taken in that fashion, it is much harder work than fine sport; and, as is the case, I think, with most game tish, the largest neither give the most sport to the fisherman on the hook, nor to the epicure on - the board. The gamest fish for the one, and the most delicate for the other, is the fellow that runs from seven, or, by'r lady, five to ten pounds weight, and he will work you on the line, or please you on the platter.

Of that size, boil him, and serve him with anchovy or shrimp sauce and the squeeze of a lemon; or roast him, stuffed with bread-crumbs, suet, sweet herbs, lemon peel, and oysters, and basted with anchovy-butter, and if you don't say he's good, you may take my best rod and line.

If he's a little fellow, score his sides, pepper and butter liim, and boil him-or, if you've a lot of them, with a bunch or two of silver Passaic eels, pork, onions, potatoes, oysters, \&c., cut them in chunks, and make a chowder of them, with the oysters on top, and don't forget to throw in a pint of dry champagne when it boils up, or to think of Franls Forester, after the first plateful. After the striped Bass has had his own fun with the 
smelt and shad-roe, in the spring, he disappears from among us for a time, having run up nearly to the headwaters of his breeding streams, where he may deposit his ova in the clear, cold aërated waters, running limpid over yellow sands and bright pebbles, which are the best suited to the reproduction of his species.

Soon after he has performed this duty, he returns, far less reduced, I know not wherefore, by the act of spawning, than other anadromous fishes; and, thereafter, during the hot months of midsummer, and the earlier part of autumn, he is to be found in the estuaries, and the silver-flashing surges of our outer beaches, where he is taken in great abundance by the amphibious population of those regions, with the squid and hand line.

Later in the autumn, he again rushes up the rivers, partly in pursuit of his prey, and partly, it is supposed, from dislike to the tumultuous seas, produced by the winter storms ; since it cannot be, as was once imagined, in avoidance of cold that he winters in fresh water, for it is ascertained that salt water maintains the highest temperature. In the rivers, however, it is, or rather in the lagoońs and shallow bays at their mouth, that he passes the cold season, lying in a half torpid state on the mud at the bottom; nor even here is he safe, at least in northern-regions, for Mr. Perley states that he is easily distinguished in the shallow waters, through the clear, newly-formed ice, which is speedily cut through, and friend Labrax fished up in scoop-nets by the Micmacs and Milicetes, no slight addition to their frugal winter fare. 


\section{V.}

\section{MAY.}

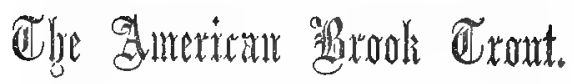 Salino Fontinutis.}

NORTH AMEIICA; LABRADOR TO THE PACIFIC.

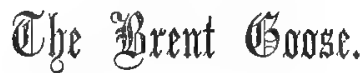

Anas Berniala. 




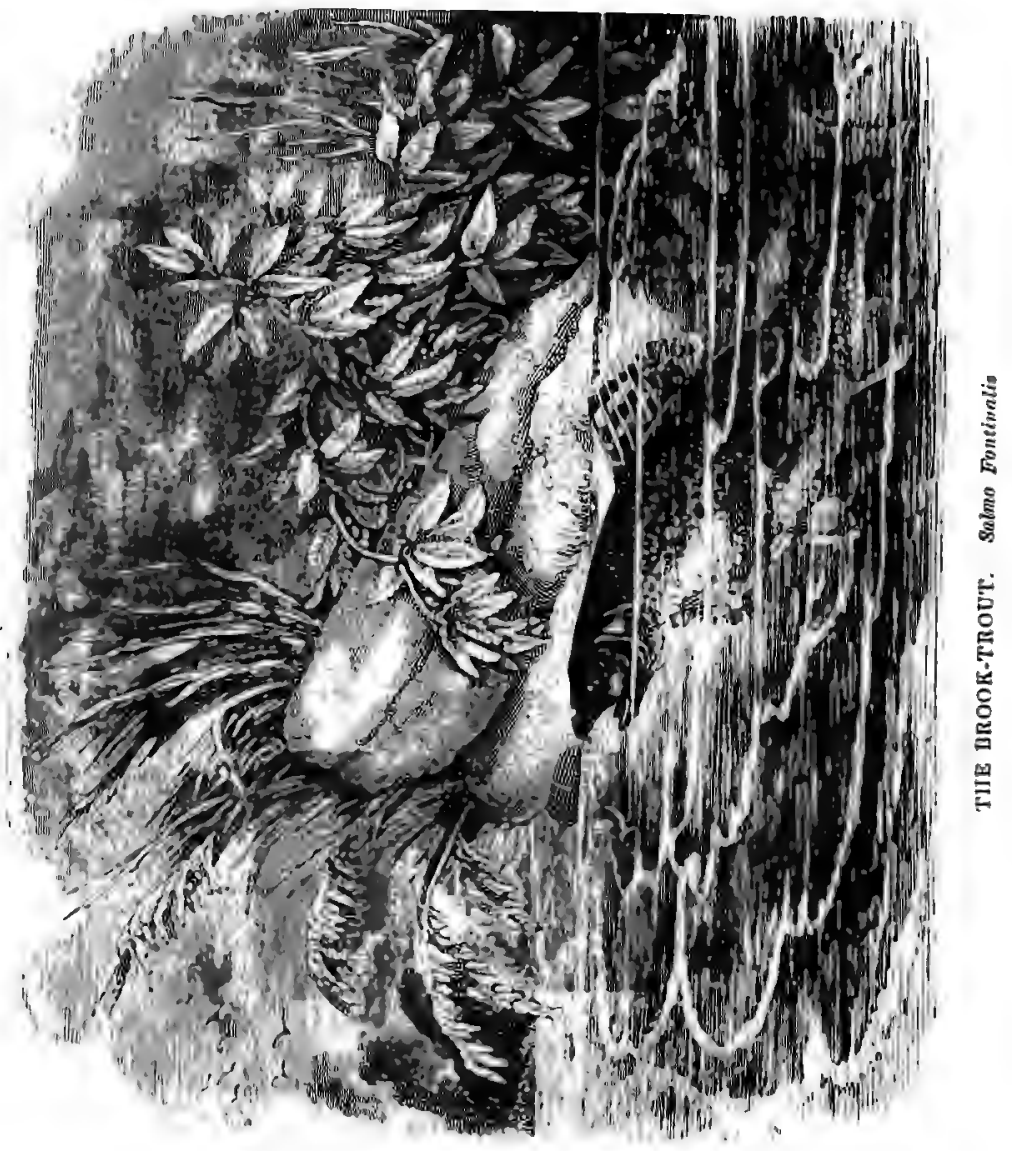




\section{THE BROOK TROUT.}

\section{Salmo Fontinalis.}

Turs merry month of May is the month of all others dear prescriptively to the trout-fisher. In England, it has been for centuries admitted the sweetest and the fairest month of spring; the month "where sweets compacted lie, the union of the earth and sky." Poets have sung it, and traditions hallowed it; and, from the old day, when the hoary druids culled with their golden hooks the sacred mistletoe, and the young maidens were astir before the morning star, to gather maydew in the. flowery meadows, even to this hard, real, unideal nineteenth century, the month of May has a character of its own, not with young lovers only, but with the world in general, different from that of any other of the twelve changeful cycles, and differently hailed of men.

In England, as I have said, it is the sweetest, with us in Arnerica it is the first, I had almost said the only month of spring. For, in our western hemisphere, the winter hangs so heavily, and lingers so late into the $6^{*}$ 
lap of summer, that in good truth, in some years, wi have no spring at all; and in the most favorable seasons the fierce and cutting north-easters of March, with thei: whirling snow-drifts, their pelting hail-stones, and thei incessant scud of inky storm-clouds, render it the mos hateful month of all the twelve, and to invalids the mos: terrible and fatal. April succeeds; and if one genia. day, with a soft breeze from the southward or south. westward, and a glimpse or two of watery sunshine, call the willow-buds to bursting, and a few, the earliest: meadow-blooms to blowing; waken the whistle of the blue-bird among the-apple-boughs, and the chirrup of the frog from the morasses, the next is sure to follow, loaded with sheeted mists sullenly sailing westward before a soul-searching and ice-cold gale from Labrador or Greenland, and the promise of the year is not only deferred, but, it may well be, nipped outright, for that the earth has reposed rash faith in the fair but falseseeming visage of the skies.

But, with May, if there be any vernal weather coming; we have it present. The fury of the east wind, if not quelled, is broken; and we shall have green leaves rustling into breezy life, and warblers busy in the orchards, brown thrushes vocal in the woodlands, swallows skimming the pools and twittering in the eaves; and last, not least, trout flashing through the glassy ripples, as they spring fast and frequent to clutch 
the insect food which come forth now so plenteously to sport their little day in the warm sunshine.

Along the Atlantic coast, indeed, on Long Island, and to the eastward, where, in fact, alone on the Atlantic coast of the United States trout prevail, fishing is permitted by law, and practised by sportsmen, long before this, the true month of the fly-fisher. In March it commences on the Island, where formerly was the finest trout-fishing perhaps in all the country; but where the streams are now whipped so severely, that, in spite of stringent regulations lately resorted to-too lately-in the vain hope of preserving them, the run of fish are declining in size year after year, and a good day's sport, is fast getting to be a thing little to be expected, scarce even to be hoped for. In March, the trout will rarely look at the fly, and they are caught at this season for the most part with the float and red, or brandling worm; on bright, warm days, however, they will at times take the artificial fly, and it is remarkable that very early in the season they will rise at a bright, gaudy fly, like nothing in nature, which a month or two later they would probably reject with contempt. Two or three years ago, the most killing early fly was a scarlet Ibis wing, scarlet silk. and gold twist body; but subsequently it has failed so generally, as to have fallen into some sort of disrepute. The flies especially recommended for this month, imitations of the natural insects, are the red fly, blue dun, .red spinner, great dark dun, cow-dung fly, March brown, 
or dun drake; and great red spinner; and any of these are well-proved and successful flies in England; but in this country the fact is, that even in the warmest regions in which the American brook-trout is found, the natural fly of any kind is scarcely on the water at all at this season; and that one is just as likely as the other. April brings the golden dun midge, the sand fly, the stone fly, the grannom, or green tail, the yellow dun, the iron-blue dun, the jenny-spinner, and the hawthorn fly. The third, fourth, and fifth of which will be found very tempting during the whole period of spring fishing; as will also, or perhaps I should say, more so, the yellow May dun, the black gnat, the downhill fly, the Turkey brown, little dark spinner, yellow Sally, fern fly, or soldier, alder fly, and green and gray drake, which may be regarded as particularly, according to the doctrin. aires, the flies of the month. I confess that I am not myself a believer in the use of particular flies, for particular months or seasons, except as regards particular waters; and, in fact, such an application is utterly impossible in a country of the extent of the trout-fishing region of North America; where the months and the very seasons differ by twenties and forties of degrees. The trout-fishing region of North America may be said, generally, to extend from. Nova Scotia and Lower Canada, eastward to the feeders of Lake Superior on the west, and from the extreme northern seas to the Atlantic. coasts, eastward of the Hudson. Westward of that 
river, they are scarcely found south of the Alleghany ridges, nor in the Western States south of the Great Lakes, or west of Michigan, until we reach the Pacific watershed.* Now, as this district extends over not less than thirty-five degrees of longitude from east to west, by fifteen of latitude from north to south, it must be obvious that no general rules can be adopted which shall be applicable to the whole of that vast tract. In the British provinces, and Lower Canada, the rivers are not clear of thick ice until the end of April or early in May; and in the western country, on Lakes Furon and Superior, the season, if any thing, is later. On Long Island, in May, trout-fishing is nearly at an end; on the Callicoon, the Beaverkill, and the various tributaries of the upper Delaware and Susquehanna, it is then beginning, and is shortly after 'in its perfection. On the superb lakes and streams of Hamilton county, New York, and of the North Eastern States, June is the month par excellence; and probably, for those who can endure the pest of the black fly and black midge, there is no such fishing in the world, for extent of water, quantity, and size of fish, and loveliness of scenery, as the former locality can afford to those who are bold enough

* In the Western and Southern States several different fish, in nowise connected with the trout, nor belonging to the same family salmo, are known as trout. The fish so called from South Carolina, southward, is a variety of the Squeteague or wheat fish, Otolithus Carolinensis-that misiamed trout in the West is a species of fresh water bass, or corvina. 
to defy the plague of flies, and rough it. At the Sault St. Marie, the outlet of Lake Superior into Lake Huron, where the St. Marie, a river abore a mile wide, rushes in a sheet of glancing and foaming rapids, down a descent of some twenty-four feet in about a mile, literally alive with the most magnificent brook-trout, by far the largest, in the general run, of any taken in Afnerica, the season does not begin until very late, and the fishing is not considered to be in its prime until September. The fish here are of the finest quality, for size, beauty of coloring, and excellence of flesh. From two to three pound may be considered, I think, as about the average run of fish, but five and six pounders are by no means rarities; and it is on record that one fish a little exceeding ten pounds, and many exceeding nine, were brought into the American fort by the Indians, a premium having been offered for a ten-pounder. These, I wish it to be particularly observed, are not lake trout of any variety - several species of which are found in the same waters -but the genuine red-spotted brook-trout, with pink sides and silver belly, and tricolored fins, white, black, and red, when in high season. It differs in nothing, except size and brilliancy of tints, both the result of feeding and quality of water, from the famous Long Island trout of Snedecor's and Carman's, or from the small fry, scarcely bigger than minnows, which swarm in every rocky basin of every mountain brooklet from 
Maine, New Hampshire, and Vermont, to upland Pennsylvania.

The fishing at the Sault St. Marie is difficult, because it is practiced from that, to one unaccustomed to its use, most ticklish of all vessels, a birch-bark canoe, poled by an Indian up the foaming rapids, or guided down them, and held steady from time to time in the most favorable spots. Where, however, the angler is so well accustomed to his conveyance as to be able to balance his body without bracing it, and move his arms without danger of upsetting the canoe, the sport is admirable, the scene enchanting, and the fun vastly enhanced by the touch of romance and possibility of danger, which, however, with a good Indian at the pole or paddle, amounts to no more at most than a possibility. The best rod to use in this powerful and tumultuous torrent is a tolerably stiff fourteen foot fly-rod; the water is so much broken, that tackle may be used which, from its coarsèness, would be quite out of the question in fine and clear waters; and the most killing flies are large and moderately gandy lake flies. Such as are used on the Irish lakes I prefer to the very fancy-colored flies which are often used on the Hamilton county waters, and the very best assortment of these I have ever seen, were tied by my friend "Dinks," of Canada West, who has proved them murderous in that locale.

It must, of course, be evident, that in a paper limited in length such as this, it is utterly impossible to go at 
length into a subject so intricate and so full of details, as the habits and nature of trout, their haunts, habitations, and all the various devices for taking them which have been invented by the ingenuity of man.

Of fresh water fish, they have been in all ages considered the best on the board; and, as fish of game, none except others of their own family, such as the salmon, the salmon-trout, the grayling, and one variety of the lake-trout, are worthy of comparison to them; bold, active, and fierce in pursuit of their prey, voracious in their appetites, so cunning and quick-sighted that they can be deceived only by the finest of tackle, and the most exquisite imitations of the flies on which they feed by preference; so vigorous, determined and savage in their resistance to the hook after being struck, that they can be mastered only by a rare combination of science and skill, of delicacy and firmness, of perseverance and resources; the capture of the brook-trout with the artificial fly and single gut, or single horse-hair, which must be had recourse to where the streams are fine and the fish shy, is the very ne plus ultra, and has ever been so indisputably admitted, of the anglers' art. The implements are a light twelve-foot rod, very pliable and springy, and bending on a strain, in an even curve from the second joint to the tip-I prefer a solid butt, which gives more power in leverage and resistance against a strong run-away fish, and the spare lips can be carried in the handle of the landing-net, or gaff-a good click 
reel, by no means a multiplier, thirty lines of good hair, or hair and silk line, with a casting line of the best gut, about four and a half or five feet in length, and two or three casts of flies, twisted round your hat, each having a different fly for the dropper, to be changed, accordingly as you find fish in the humor to rise.

My own farorites are the marlow buzz, better known as the coch-a-bonddlue; silver-horns, black and silver twist hackle, the green and gray drakes, the yellow Sally, the downhill fly, woodcock wing, and red hackle, the grannon, or green tail, the blue and yellow dun flies, and almost any of the spinners. I am also rather partial to the buzz-dressed, unwinged hackle flies of almost any color, with red, green, black or yellow bodies, which may be varied with gold or silver twist. Any of these I can recommend by experience as killing flies; I should not omit the small black midge, which on some waters, and in some states of weather, is a most killing lure to wary fish, being very small, and requiring delicate tackle. Where waters are much fished, and trout so much persecuted as to be very shy of rising, sport may sometimes be had by fishing at twilight with a large white miller, white hen's wing, white chevil body and black head, and as the largest and laziest, and, of course, fattest fish rarely pursue their prey in the day time, but are on the feed all night, if any sport is to be had at all in this manner; it is nearly certain to be good sport.

Large tront may be killed thus in the upper Delaware, 
along the line of the Erie railroad, where the country people will tell you that there are no tront in the river, though the small creeks are full of them. The truth is the fish in the river are very much fewer in number, but as much superior in size and weight. They who, like me, prefer to kill a one, two or three-pounder to ten dozen fingerlings of four or five ounces each, are advised to try the miller by dusk or by moonlight, and if there be a big fellow about, he is pretty sure to be tempted.

The trout does not, when feeding, travel or swim in shoals; he lies in wait in his own peculiar haunt, and thence strikes at whatever he sees passing that tempts his appetite. This haunt is generally in the neighborhood of a stone or root, near the head or tail of a rapid, in an eddy or swirl of the current, or in the broken water caused by the division of a current above the head of an island or shoal, and its reunion below it. Here they lie with the head up stream, perfectly motionless, not even wagging a tail or twinkling a fin, until their object is in view, and then darting upon it with speed that mocks the eye. They are insensible to sound, but so quick of sight, and so wary that the mere shadow. of the rod projected across the water will prevent their taking a fly, however hungry they may be, and however skillfully the lnre may be presented.

It is better to fish dowi stream, away from the sun, and across the wind, if possible; but the three contingencies are not always compatible. When a trout is 
rising often, endeavor to drop your fly directly in the centre of the circle where he bells up, and if it alights lightly and gently on the water, he will pretty certainly take it. If he takes it just as it strikes the water, or just as it is leaving it, when you are withdrawing it for another cast-that is, when your line is perfectly straight and tight, he will hook himself; otherwise it is necessary to strike him, which is done by a very slight indescribable inward turn of the wrist; when he is struck, the great secret of playing and killing him is to make him fight his hardest for every inch of line you give him, never to give him one which he does not take, and to zniss no opportunity, when his rum is over for the moment, and he is weakened, to reel in as fast as you may without overstraining; always endeavor to carry him down stream, as the gills are so closed by the action of the water, and his breathing.is impeded. If he is making for a stone or piles whereon your tackle would probably be broken, or down a fall, so that you must turn or lose him, advance your butt, inclining your rod quite backward over the right shoulder, so as to make him take the full strain and leverage of the whole length of your rod; when he is dead beat, draw him warily and gently into the shcal water, or to your boat side, slip your landing-net under, or your gaff into him, and be is yours.

If he be above two pounds weight, stun him witlr a blow on the head, crbssing by a series of cuts parallel to 
the gills, at about two inches apart from head to tail, cool him for ten minutes in a very cold spring, or on ice, boil him in screeching hot salt ànd water, and eat him with no condiment but salt and the squeeze of a lemon.

If he be under a pound, there is nothing for it but to fry him, but remember to use neither butter nor lard, which are abominations to the gnostic, but the best oil of Aix, and see that the oil is seething and the pan crackling hot before you put them in. Garnish with fried parsley on a very.hot dish; and in whichever way you cook them, eat them-whenever you can get them, that is to say, between March and September-in the northwest you may substitute for the last November; on the third of which month, last season, I discoursed sundry in prime condition, at mine host Brown's, on the Sault St. Marie; and the taste is scarce out of my mouth yet. I have tasted nothing like them since, or expect to do so until next September, when, the wind and weather-gods permitting, I hope to wet a line there; in the Fly-fisher's true Paradise. And may you have, whoever you be, gentle reader, and wheresoever you throw the long line and neat fly, such sport as I anticipate. 



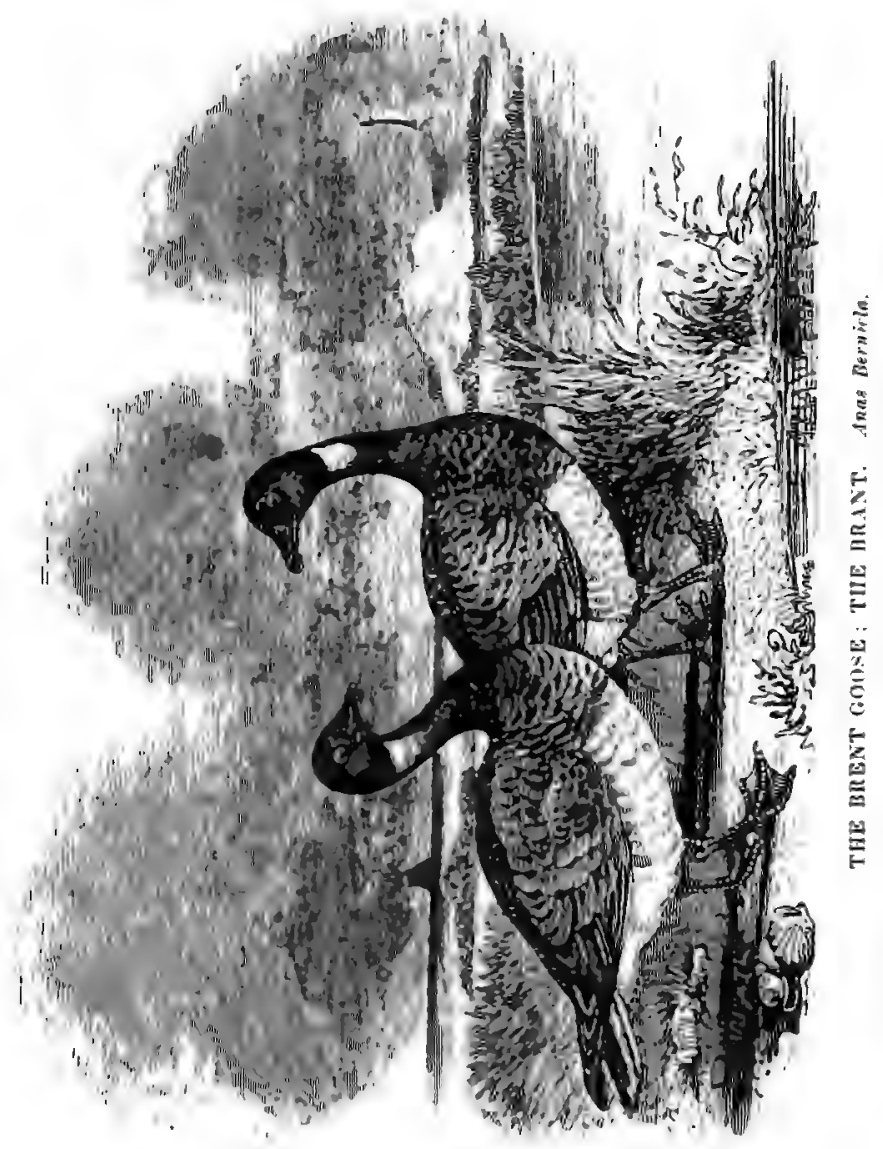




\section{THE BRENT GOOSE.}

\section{The BRAnt. - Anas Bernicha.}

THIs beautiful and delicious wild-fowl, like several of its congenors which breed within the limits of the Arctic Circle, is common to both continents of Europe and America, and is with us in the northern Atlantic states perhaps the most numerous, and certainly the most esteemed, whether as an object of sport or an article of food, of the varieties of this family, which are common upon our coasts. To the Canada Goose, or Wild-Goose, as it is more usually termed, Anas Canadensis, it is universally, and not undeservedly, preferred; althongh, in my opinion, the former is itself entitled to a far higher place than is generally assigned to it among the waterfowl of America. The Snow-Goose, Anas Hyperboreus, and the White-Fronted Goose, Anas Albifrons, are so rare that opportunities seldom occur of testing their comparative excellence. In England I once tasted the latter fowl, and found it scarcely distinguishable from the Grey Lag, or common Wild-Goose of Europe, Anas Anser, 
which in my opinion is inferior both to the Canada and the Brent Goose; and though I have heard the Snow-Goose lighly lauded for its delicacy and juiciness, I believe we shall do no injustice to any in declaring the Brant, facile et nulto discrimine princeps.

It is worthy of remark that the habits of this bird are greatly different in England and in this country, inasmuch as there they are stated "to spend the winter months in the rivers, lakes and marshes in the interior parts, feeding materially upon the roots and also the blades of the long, coarse grasses, and plants which grow in the water." Here they are entirely marine birds, frequenting the outer estuaries of the large rivers, the land-locked lagoons or sea bays, which lie between our outer beaches and the shores proper of the continent, for so many degrees of latitude along our Atlantic seaboard, and never, so far as I know or have heard, entering our rivers proper, or being killed in any fresh inland waters. So strongly is this peculiarity marked in the Brent Goose, that when they leave their feeding-grounds to the northward, compelled by stress of climate in winter, for lower latitudes, and again when they take their departure for the Arctic regions, impelled

creandæ*

Prolis amore, gravique cupidine nidificandi,

* By the affection for the young which they are about to rear, and the urgent desire of nidification.--Lucretius on Brent Geese. 
"thes collect," says Wilson, "in one large body, and making an extensive spiral course, some milles in diameter, rise to a great height in the air, and then steer for the sea, over which they uniformly travel; often making wide circuits to aroid passing over a projecting point of land. In these aerial routes, they have been often met with many leagues from shore, travelling the whole night. Their line of march rery much resembles that of the Canada Goose, with this exception, that frequently three or four are crowded together in front, as if striving for precedency."

To such a length is this terror of the land passage carried by the Brent Goose, that no doubt can be, I think, reasonably entertained that, in order to aroid it, they make the whole of their rast migration, to and fro, from their breeding-places hither, and rice cers $\hat{a}$, in direct contradiction to the custom of their congenors, the Canada Geese, which travel from point to point, in direct lines, directed by an instinct certain as the compass, and trarelling the boundless wildernesses and rast inland waters of the northern ternitories, and the cultirated regions which intervene between those and their winter hannts on the seashores of the Atlantic, with unrivaled speed and unerring sagacity. A pretty certain proof of this is to be found in the fact, that on the northern shores of Lakes Huron and Superior, and in the small rice lakes adjoining them, although abounding in their favorite food, the eel-grass, ànd frequented in myriads of millions 
by the Canada Goose, on the breaking up of the ice in spring, and again at the setting in of winter, the Brent Goose is unknown both to the Indians and to the white settlers; nor are they known about the yet more northerly forts of the Hudson's Bay Company-short of the Bay itself, where they abound-who regard the Canada Goose as one of the principal, if not the chief article of their subsistence.

The breeding place of the Brent Goose is very far to the north, though not so far as that of the Wild-Goose, which is supposed, not without reason, to rear its young and pass the bricf days of summer of the Arctic Circle in the regions of the Pole itself, while the Brent has been found on its nests in Labrador, to the northward of Hudson's Bay and in Boothia Felix. Here, fearless of the ambushed gun, and the murderous battery, it revels during a few short months in those to it delightful solitudes, occupied with the charms of love, and the cares of rearing its young. It does not, howerer, tarry long in its northern asylum, as it is usually looked for in the Long Island waters, and at Barnegat, Egg Harbor, and other shooting stations on the Jersey coast, early in October, and has been seen so early as the 20th of September. Its - stay in these places is uncertain, depending very much on the nature of the season, often remaining, if it be open weatler, during nearly the whole of the winter, while on the contrary, if the bays are frozen early, it at once towers aloft and takes its way southward. It seems, how . 
ever, to come southward continually by successive partial migrations, until the freezing of the feeding-grounds compel it to march southwardly.

The food of the Brant is principally the eel-grass, Zostera Marina, wherever that favorite dainty of all the aquatic tribes is to be found in plenty, and a broad-leaved, bright green marine plant, called by the country people sea-cabbage, which adheres to the stones on most of our beaches. After these it nerer dives-although it is remarkable that when wing-tipped it is the most dexterous of the family, often going a hundred yards or upward under water, and being therefore regarded as almost impossible to kill, if not shot dead outright. At low water it wades about incessantly, tearing up its favorite vegetables by the roots, but neglecting to eat them until they are floated away with the rising tide, when it does not take wing, as most wild-fowl, but floats away idly in long lines with its companions, in pursuit of its now floating dainty, and fares sumptuously on the proceeds. of its previous industry. They are not unpugnacious birds, being often seen fighting among themselves, and beating the ducks away from their feeding-grounds; their cry is a hoarse, gabbling, honking sound, very different, howerer, from the honk of the Wild-Goose, and by far more difficult to imitate, and is said closely to resemble, when several hundreds are screaming together, the chorus of a pack of hounds in full cry.

On their return from the south, with renovated powers, 
in full, lusty health, rejuvenated, and exalting in the approach of their summer love-making, they are in their full perfection of plumage, and their utmost excellence for the table. There is no Long Islander, and few Jerseymen, who are not fully awake to the preëminent merits of a May Brant-for it is about the fifteenth of that genial month, when they for the first time reappear among us, the youth of the past year now in full adult plumage, and not to be distinguished from the adults. They tarry, however, at this period but for a few days, ere they are again up and off to the northward; still so eager are their pursuers at this season, that short as is their stay the havoc made among them is yet not inconsiderable.

At this season the Brant weighs about four pounds, and measures two feet in length from bill to tail, and three feet six from tip to tip of the extended wings. The bill is black, rather high at the base, the nostril medial. The head, and the whole length of the neck, with the exception of a white oblong patch on either side of the throat, rich velvety black; front part of the breast cinerious brown, each feather broadly margined with grayish white. The upper parts blackish brown, each feather margined with lighter brown; sides gray, margined with white; abdomen and vent pure white; quills and primary coverts dark blackish gray. Rump and middle tail feathers black, rest of the tail grayish white. Irides hazel ; legs dusky. The female is smaller than the male, 
but not to be distinguished from it by any mark of the plumage; the young birds have the wing quill feathers broadly tipped with white, while in the old birds they are purely black.

There is a variety of this tine goose, pretty well known on Long Island, the true name of which is Hutchins' Goose, or Hutchins' Brant; it is somewhat smaller, and in lieu of the lateral white throat patches, has a white gorget a good deal similar to that of the Canada Goose.

We now come to the modes of killing this delicious bird, of which there are four; three of them, me judice, utterly unallowable, cockney and pot-hunter like, and the fourth unhappily the least profitable to the gunner, although the Brent Goose has one habit which may be used to some advantage in this the only legitimate mode. That mode is the scooping out a niche from the muddy side of some island, or point of hassock, kussick, or thatch, as it is called in the bays, and therein mooring a skiff, or Egg Harbor boat, with its decks heaped with trash and sea-weeds, the gunner lying on his back therein, with his two heavy guns prepared for a passing flock, and his decoys scattered orer the calm waters in front of him, when if a flcck chance to pass, and, observing the anchored deceits, wheel down to them, he is secure at once of sport, and of after excitement in pursuing and picking up the cripples.

The disadvantages to this method are the following: First, the Brant is on our waters a lazy, inactive bird, 
averse to rising on the wing, and rarely doing so unless alarmed by a passing boat or the firing of a gun; and this tendency is increased in consequence of its feeding afloat at high water, without taking the wing at all, while the other varieties of wild-fowl, as point after point is successively submerged, are compelled to take wing; and cross the points of hassock, or run the gauntlet of the islands in going to or returning from his favorite feeding place.

Second, the known aversion of this bird to pass over or near points or islands, which is no less manifest in its transits up and down the bay, than in its longer voyages, for it may be said that it never when on the wing approaches the gunner's ambush, or notices his decoys, however temptingly they may ride and dip at anchor, when near the land, unless they be jammed down by the wind upon a leeward point, one of which is always selected by the best gunners who have watched the direction of their morning trausit, and who know how they must return. This difficulty is but partially compensated by the habit of the Brant of occasionally swimming in among the stools, and so affording an easy and sure shot. There is another fact, however, which, as I said abore, may be made directly subservient to this sport, and thus it is-Brent Geese, while feeding, as they drift about at high water, may be herded like so mary sheep, and caused to swim in any direction desired, and may be so driven down upon the decoys, for which they are almost 
sure to make, by rowing round and after them slowly, taking especial pains not to press their motions or crowd upon them so as to compel them to take wing, when of course, all would be orer. The confederate of the gunner should therefore be wary and watchful, as well as skillful with the oar, and whenever he observes the fowl he is driving, hurrying and getting anxious, and pressing into one compact body, he must lie on his paddles entirely, until he sees his game resume their feeding or play, when he may again take the initiative. This, well done, is sure to prodnce good sport, time, tide, weather and good luck agreeing, without which, neither in Love, War, or Brant Shooting can success be looked for.

Let me commend this method to my friend, the true and honorable sportsman, who would rather return home at night weary and cold, and with an empty bag or boat, than come loaded to his gunwale with booty obtained by any indirections, such as those which I shall be forced to name hereafter, though with maledictions on the inrentors, and disgustful contempt for the practicers of them, as methods of Brant-murdering:

Let me remind the sportsman that this kind of shooting is practiced in very cold weather, in a motionless and cramped attitude, and depriving him of the chance of warming his limbs with exercise. He must, therefore, be well and warmly clad, or he shall not be able to shoot 
tolerably, much less to enjoy himself or win renown, let the flocks fly as full and frequent as they will.

The following dress I have found the best-those may sneer who will, but I think, and they will find, when their fortieth year brings crippling rheumatism, that it is wisdom at all times to be as comfortable as one may, and that it is no mark of manhood, but rather of very contemptible folly, to lie cold and shivering, for the want of a few precautions which may be easily taken, and will make you as much at your ease as may be, in a Delaware skiff or Egg-Harbor pig-box.

First, over your ordinary under-clothes wear a stout pair of Canada-gray cloth trousers; over these a pair of long worsted stockings, and over these again long pliable Canadian boots. A red flannel shirt, and above that a guernsey, with what waistcoat and shooting-jacket you will, and over all an oil-skin coat, as near as may be of the drab color of the sedge and hassock; on your head a woolen night-cap, and above it a gray tow hat; andthough your rig may terrify into convulsions a young New Yorker, with ends to his white choker longer than the yard-arms of a first-rate-take my word for it, it will not scare Brant, Goose, or Red-Head from your stools, and it will keep you, with the aid of a modicum of cogniac, Jamaica, or Ferintosh, as your taste may incline, cozy and good-natured, while your friend, who is too manly to take counsel, is as cold and as cross as whatever is most frigid and most fiendish. 
I recommend-for reasons why, too long here to set forward, - see my Field Sports, vol. II., p. 119-the use of two single guns of $16 \mathrm{lbs}$. weight, 42 inch barrels and 5 guage, in preference to any double-barrel guns on earth for this shooting. They should be made without ribs, pipes or ramrods-a loose loading-rod, which is a cleaning-rod also, lying in the boat when in use, being adopted as a substitute. This should be made with a joint at exactly the length of the gun-barrel, so that it can be carried within it when travelling; the upper joint about 6 inches in length, screwing into the other, and fitted with a lnot at the top, like a pistol-charger, may be carried in the pocket when in locomotion. Such a gun will carry 4 oz. of BB, or twenty-fire buck-shot, without jar or recoil; use equal measures of shot and Curtis and Harvey's ducking powder, to be procured of Brough, Fulton-street; New York-and coarse felt punched wadding, and you will do your work at eighty, ay, by'r lady! or one hundred yards, and you will not repent you of following my counsel.

The murderous modes, which I have so strongly reprobated, and to which I shall devote but a few words, are, first, the anchoring batteries, as they are called, shallow coffin-like boxes, supported by wide horizontal brims lying level on the surface of the water, covered with sand and shells, and exactly resembling a bit of bare shoal, upon the shallows whereon the fowl feed. Decoys are placed around, and an attendant waits in a skiff to secure 
the cripples and drive up fresh flocks, while the gunner lies perdu literally under water, until he starts up to do bloody execution.

The evil of this method, (of the other two, which I shall barely name, as they are far less practiced, one, I believe, only at one point, is, that fowl, when constantly harassed and disturbed on their farorite grounds, while in the act of feeding, will rise high into the air and desert the places in which they are so wantonly tormented forever; whereas they may be peppered at day by day for years, and decimated as they fly to and fro without connecting the idea of the persecution with the feeding grounds, and without increasing in shyness or decreasing in numbers.

The second unsportsmanly and slaughterous plan is running down upon them before the wind under sail, while on their feeding grounds, which is easily done, as the fowl appear wholly unable to distinguish the rate of a sail-boat, and let it run closely in upon them before they will take wing. The havoc thus made is prodigions; the consequences as above, the permanent and entire desertion of the spots where such brutalities are practiced. The last is akin to these. It is a necessity to the Brant to sand and dust themselves occasionally, and probably to obtain small gravel-stones to aid their digestion, and they have regular sanding places, as they are termed, to which they punctually and constantly resort. This habit observed, the pot-hunter digs his hole in the sand-hill, 
watches his time, and counts his slaughter by flocks, at shots. Like the owner of the goose with the golden eggs, he will find too late that he has killed his people as Nero wished to do, at a single blow. Legislation has been tried, against all these three cowardly iniquities, and of course tried in vain. It rests to see what inculcating a spirit of sportsmanship may do ; but I am little sanguine, seeing that true sportsmanship, like the game it fain would, but cannot, protect, decreases year by year-many of those who boast themselves sportsmen, and here an I would I could name names, doing deeds the foullest pot-hunter would shrink from, and holding themselves as high as ever in their own esteem, though lower than the lowest in the judgment of the judicious.

Be this, however, as it may be, the only hope is in the efforts of the honorable sportsman, and so let him hopeful ever of the best, hold the helm steady, steer on through squall or hurricane, and never-whatever betide-never give up the ship! 



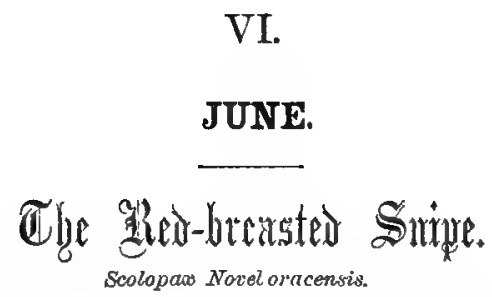

ROBIN SNIPE, QUAIL SNIPE, DOWITCHER. THE HUDSONIAN GODWIT.

Limosa Hudsonica.

\section{RING-TAILED MARLIN.}

NORTH AMERICA; LABRADOR TO THE GULF.

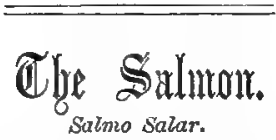

LABRADOR; BRITISH PROVINCES; STATE OF MAINE. 




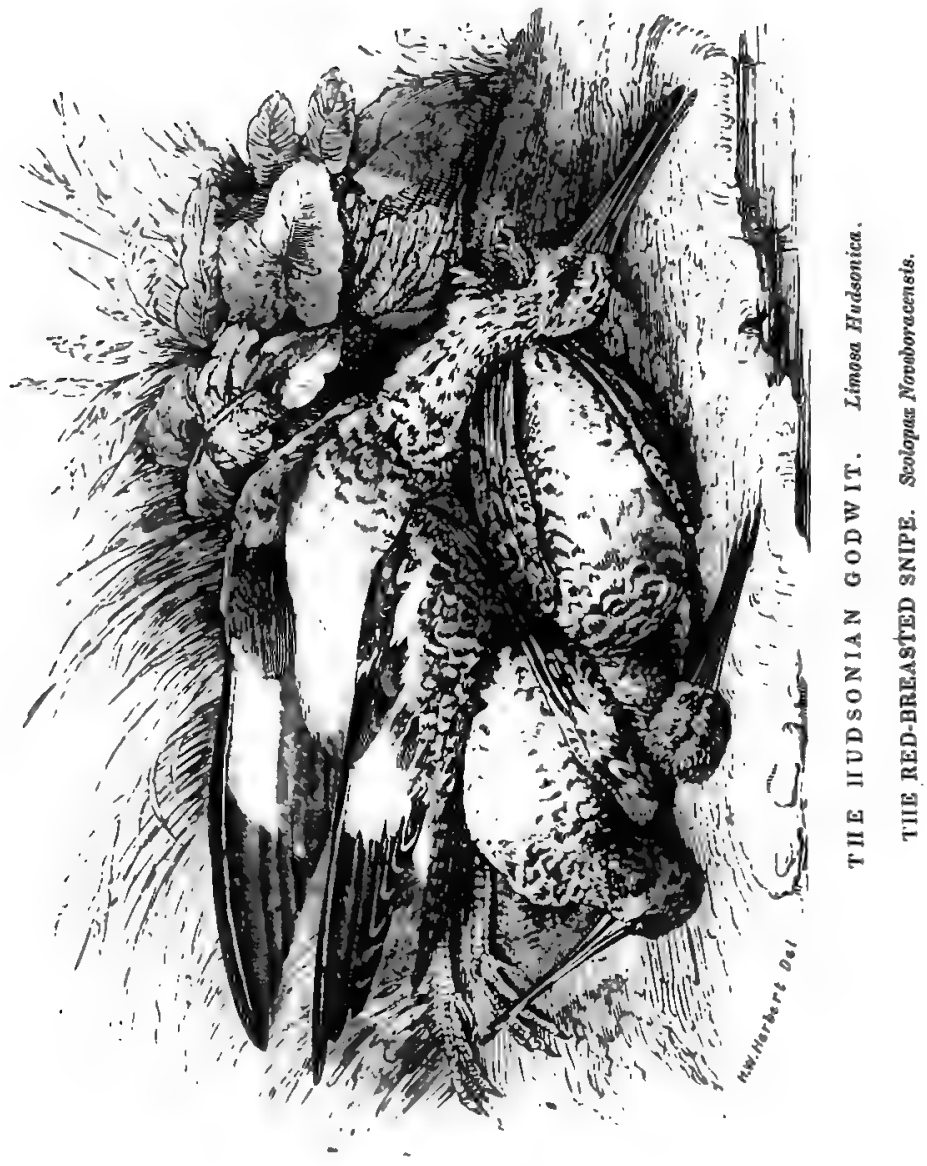




\section{THE SNIPE.}

THE BUDSONIAN goDwrr.-Limosa Hudsonica.

Vulgo. RING-TATLED MARLIN.

THE RED-BREASTED SNIPE.-Scolopa $x$ Noveboracensis. Vulgo. ROBIN-BREAST; QUAUT SNIPE, DOWITCHITR.

UNDER the general, and very incorrect appellation of Bay Snipe, and sometimes of Plover, the sea-shore ginners, and city fowlers who accompany them for pleasure, are wont to include many totally distinct and different families of waders, each containing several varieties, and all, though in some sort connected, entirely dissimilar in characteristics, plumage, cry and flight, as well as in some peculiarities of habit.

Of these families, the most remarkable are the Curlew, numenius; the Godwit, limosa ; the Sandpiper, tringa; the Tattler, totanus ; the Plover, charadrius; the Snipe, scolopax; the Turnstone, strepsitas; the Sanderling, calidris; the Avoset, recurvirosta; and the Stilt, himantopus; all of which at some period of the year are visiters or temporary inhabitants of some portion of the Atlantic 
shores of North America, from the Bay of Boston to the Balize.

In the tepid waters of Florida, the great bay of Mobile, the sea lakes of Borgne and Pontchartrain, and all along the muddy shoals and alluvial flats of the lower Mississippi, these aquatic races dwell in myriads during the winter months, when the ice is thick even in the sea bays of the Delaware and Chesapeake, and when all the gushing streams and vocal rivulets of the Northern and Middle States, are bound in frozen silence. In the spring, according to the temperature of the season, from the middle of April until the end of May, these migratory tribes begin to visit us of the northern shores, from the Capes of the Chesapeake, along all the river estua. ries, sea bars, lagoons, and land-locked bays, as they are incorrectly termed, of Maryland and Delaware, the Jersey shores and the Long Island waters, so far as to Boston Bay, beyond which the iron-bound and rugged nature of the coast deters them from adventuring, in the great flights with which they infest our more succulent alluvial shores and sea marshes.

With the end of May, with the exception only of a few loitering stragglers, wounded, perhaps, or wing-worn, which linger after the departure of their brethren, they have all departed, steering their way, unseen, at immense altitudes, through the trackless air, across the mighty continent, across the vast lakes of the north, across the unreclaimed and almosi unknown hunting-grounds of 
the red man, to those remote and nearly inaccessible morasses of the Arctic Regions whither the foot of man has rarely penetrated, and where the silence of ages is interrupted only by the roll of the ocean surf, the thunderous crash of some falling iceberg, and the continuous clangor of the myriads and millions of aquatic fowl, . which pass the period of reproduction in those lone and gloomy, but to them secure and delightful asylunis. Early in the autumn, or, to speak more correctly, in the latter days of summer, the Bay birds begin to return in hordes innumerable, recruited by the young of the season, which, not having as yet indued the full plumage of their respective tribes, are often mistaken by sportsmen and gunners, unacquainted with the distinctions of natural history, for new species. During the autumu, they are much more settled and less restless in their habits than during the spring visit, when they are inpelled northward by the irresistible astrum, which at that period stimulates all the migratory birds, even those reared in confinement and caged from the nest, to get under way and travel, whither their wondrous instinct orders them, in order to the reprodnction of their kind in the localities most genial and secure.

Throughout the months of August and September, they literally swarm on all our sand-bars, salt meadows, and wild sea-marshes, feeding on the beaches and about the shallow pools left by the retiring tide, on the marine animalculæ, worms, aquatic insects, small crabs, minute 
shell-fish, and fry; after this time, commencing from the beginning of October, they move southward for winter quarters, although some species tarry later than others, and some loitering individuals of all the species linger behind until they have assumed their winter garniture, . when they are again liable to be mistaken for unknown varieties.

Of these-misnamed Bay Snipe, the following are the species of each family most prized by the sportsman and the epicure, all of which are eagerly pursued by the gunner, finding a ready sale at all times, although, me judice, their flesh is, for the most part, so oily, rank and sedgy, that they are rather nauseous than delicate or palatable. Much, however, depends on the state of their condition, the nature of the food on which they have fattened, and localities in which they feed; and to some persons the very flavor of which I complain as rank, sedgy and fishy, appears to take the guise of an agreeable haut gout.

The Red-breasted Sandpiper, Tringa Icelandica, known on the Long Island waters, among the small islets of which it is very abundant, as the "Robin Snipe," by which name it is generally called, owing to the resemblance of its lower plumage to that of the Redbreasted Thrush, or Robin, Turdus migratorius, of this continent. In autumn this bird assumes a dusky gray upper, and white under plumage, and is then termed the "White Robin Snipe." In point of tlesh it is one of 
the best of the Shore-birds. It is easily called down to the decors by a well simulated whistle, and is consequently killed in great numbers.

The Red-backed Sandpiper, Tringa Alpina, generally known as the "Black-breasted Plover." It is a restless, active and nimble bird, flies in dense bodies, whirling at a given signal; and at such times a single shot will frequently bring down many birds. In October it is usually very fat, and is considered excellent eating. In its autumnal plumage it is generally known to fowlers as the "Winter Snipe."

The Pectoral Sandpiper, Tringa pectoralis. This is a much smaller, but really delicious species, particularly when killed on the upland meadows, which it frequents late in the spring and early in the summer, and on which I have killed it lying well to the dog, which will point it, while spring snipe-shooting. On Long Island it is known as the "Meadow Snipe," or "Short Neck;" on the Jersey shores, about Egg Harbor, where it sometimes lingers until the early part of November, it is called the "Fat Bird," a title which it well merits; and in Pennsylvania, where it occurs frequently, is often termed the "Jack Snipe." It is these blunders in nomenclature, and multiplication of local misnomers, which render all distinctious of sportsmanship so almost incomprehensible to the inhabitants of distant districts, and so perplexing to the youthful naturalist. During the autumn of 1849 I killed the Pectoral Sandpiper in great numbers, to- 
gether with the American Golden Plover, Charadrius Marmoratus, and the Black-bellied Plover, Charadrius Helveticus, on the marshes of the Aux Canards river, near Amherstberg, in Canada West, in the month of September, and a month later at Montgomery's Pool, between lakes Sincoe and Huron.

Of the Tattlers, three only are in repute as shore-birds, the best of the species, the Bartramian Tattler, Totanus Bartramius, better known as the "Upland Plover," which is, in fact, with scarcely an exception, the most delicious of all our game-birds, being a purely upland and inland variety, and as such never, or bat extremely seldom, shot on the coast.

These three are,

The Yellow-shanks Tattler, Totanus Flavipes, vulgo, "the lesser yellow legs"-a bird, in my opinion, of very indifferent qualifications for the table, but easily decoyed, and readily answering the fowler's whistle, and therefore affording considerable sport.

The Telltale Tattler, Totanus Vociferus, vulgo, "greater yellow legs," a less numerois species than the former, and more suspicious. Its flesh, when it feeds on the spawn of the king-crab, or " Horse-shoe," is all but uneatable, but later in the season it is in better condition, and is esteemed good eating. A few are said to breed in New Jersey. In the neighborhood of Philadelphia, where these birds are shot in great numbers on the mud-flats of the Delaware from skiffs, with carefully concealed 
gunners, stealthily paddled down upon them till within close shooting distances, these birds are termed "Plovers," and the pursuit of them plover-shooting; of course wrongfully.

The last of this family is the Semipalmated Tattler, Totanus Semipalmatus, universally known as the "Willet," from its harsh and shrill cry, constantly repeated during the breeding season, the last note of which is thonght to bear some resemblance to that sound. It is a swift, rapid and easy flyer, and though rather shy when in exposed situations, can be allured to the decoys. When in good order the flesh of the Willet is very palatable, although not so greatly esteemed as its eggrs, which really are delicious.

Next to these come the Godwits, two in number, known by the unmeaning title of Marlin.

The great Marbled Godwit, Limosa Fedou, the "Marlin." This bird, though nøt very abundant, is a regular visitant of the seashores and bays in the spring and autumn. It is very watchful, and will permit of no near approach, unless some of its fellows are killed or wounded, when it will hover over the cripple, with loud, shrill cries, affording an easy opportunity of getting several barrels in succession into the flock.

And the Hudsonian Godwit, Limosa Hudsonica, or the "Ring-tailed Marlin," is a still rarer and smaller variety than the last, of very similar habits and of equal excellence in flesh. It is far more common in the Mid- 
dle States than in the Eastern districts, and is abundant in the wild and barren lands far to the northward. I have seen it shot, likewise, on the swamps of the $A u x$ Canards, to which I have already referred. This is the larger of the three birds, lying uppermost, in the group, at the head of this article; it was sketched from a fine specimen shot on the Delaware in the month of May. It is thus described by Giraud in his excellent work on the Birds of Long Island:

"Bill, blackish brown, at base of lower mandible yellow; upper parts light-brown, marked with dull-brown, and a few small, white spots; neck all ronnd brownishgray; lower parts white; largely marked with ferruginous; basal part of tail-feathers and a band crossing the rump, white. Adult with the bill slender, blackishbrown toward the tip, lighter at the base, particularly at the base of the lower mandible; a line of brownish-white from the bill to the eye; lower eyelid white. Throat white, spotted with rust color; head and neck brownishgray; lower parts white, marked with large spots of ferruginous; under tail-coverts barred with brownishblack and ferruginous; tail brownish-black cast, a whito band at the base; a band over the rump; tips of primary coverts and basis of quills white; upper tail-coverts brownish-black, their basis white; upper parts grayishbrown, scapulars marked with darker spots; feet bluish. Length fifteen inches and a half, wing eight and a half. Among the various families of birds, which are all 
known, as I have stated, by the general title of Bay Snipe, there is but one Snipe proper, and that is one of the most numerous, and perhaps the most excellent of the tribes.

The Red-breasted Snipe, Scolopax Noveboracensisthe "Dowitcher," the "Quail Snipe," the "Brown Back."

A brace of these excellent and beautiful birds are depicted as thrown carelessly on the ground, under the neck of the Ring-tailed Marlin in the preceding sketch.

This bird has the bill of the true snipe, Scolopax Americanus, excepting only that the knob at the tip of the upper mandible of the bill is less distinctly marked. The spring plumage of this bird, in which it is depicted above, is on the upper parts brownish-black, variegated with clove-brown, and light reddish-brown, the secondaries and wing-coverts tipped and edged with white. Lower parts bright orange colored ferruginous, spotted with dusky, arrow-headed spots. The abdomen paler. The tail-feathers and upper-tail coverts alternately barred with black and white; the legs and feet dull yellowish green.

"At the close of April," says Mr. Girand, "the Redbreasted Snipe arrive on the coasts of Long Island. Invited by a bountiful supply of food, at the reflux of the tide, it resorts to the mud-flats and shoals to partake of the rich supply of shell-fish and insects which nature in her plenitude has provided for it. As the tide advances, 
it retires to the bog meadows, where it is seen probing the soft ground for worms. In the spring it remains with us but a short time.' Soon after recruiting it obeys the unerring call of nature, and steers for the north, where it passes the season of reproduction. About the middle of July it returns with its young, and continues its visit during September, and if the season be open, lingers about its favorite feeding grounds until the last of the month."

The specimens from which the above sketch is taken, were procured on the Delaware so late as the latter part of May; but it must be remembered that this spring, 1850, was unusually late and backward.

This snipe associates in large flocks, is very easily whistled, flies in dense and compact bodies over the decoys, and is so gentle that, after half the flock has been cut down by the volleys of the lurking gunner, the remainder will frequently alight, and walk about demurely among their dead companions and the illusive decoys, until the pieces are reloaded, and the survivors decimated by a fresh discharge.

Even when feeding on the open mud-flats, the Redbreasted Snipe is so tame as to allow itself to be approached by the sportsman, with little or no address, running about and feeding perfectly unsuspicious, until its enemy has come within short range, when it springs with its tremulous cry only to be riddled with. the shot of the close discharge. 
The other of these birds worthy of the most attention are,

The Sanderling, Calidris Arenaria, which, though very small, is fat and excellent.

The Black-bellied Plover, Charadrines Helveticus, "Bull-headed," or "Beetle-headed Plover," a shy bird, but frequently whistled within gunshot. On the coast it is apt to be fishy, but when shot inland, and on upland pastures, of superior quality.

The American Golden Plover, Oharadrius Marmoratus, "the Frost bird;" a very beautiful' species and of rare excellence when killed on the upland, where it is found more frequently and more abundantly than on the shore.

The Long-billed Curlew, numenins Longirostris, "Sickle-bill," a large, coarse-flavored bird, easily decoyed.

The Hudsonian Curlew, numenius Hrudsonions, "Shortbilled Curlew," or "Jack Curlew." Similar to the latter in all respects, although smaller in size.

And last, the Esquimaux Curlew, numenius Boreales, "the Futes," the "Doe Bird." This bird feeds principally on the uplands, in company with the golden plovers, and on the same food, videlicit, grasshoppers, insects, seeds, worms, and berries. Its flesh is delicate and high flavored. It breeds far to the north and win.. ters far to the south of the United States, residing with us from early in August until late in November. 
With this bird, although there are numerous other smaller species, the list of these tribes may be held complete.

From the commencement of the present month until late in the autumn, anywhere along the coasts and bays of the Northern and Middle States a bag may readily be filled to overflowing with these varieties by the aid of good decoys and skillful whistling, or of a skiff paddled by a cunning fowler; a gun of 8 to 10 pounds weight, of 12 guage, with two oz. of No. 5 shot, and an equal measure of powder, will do the work. But when the work is done, comparatively the game is worthless, and the sport, as compared with upland shooting, scarcely worth the having. 



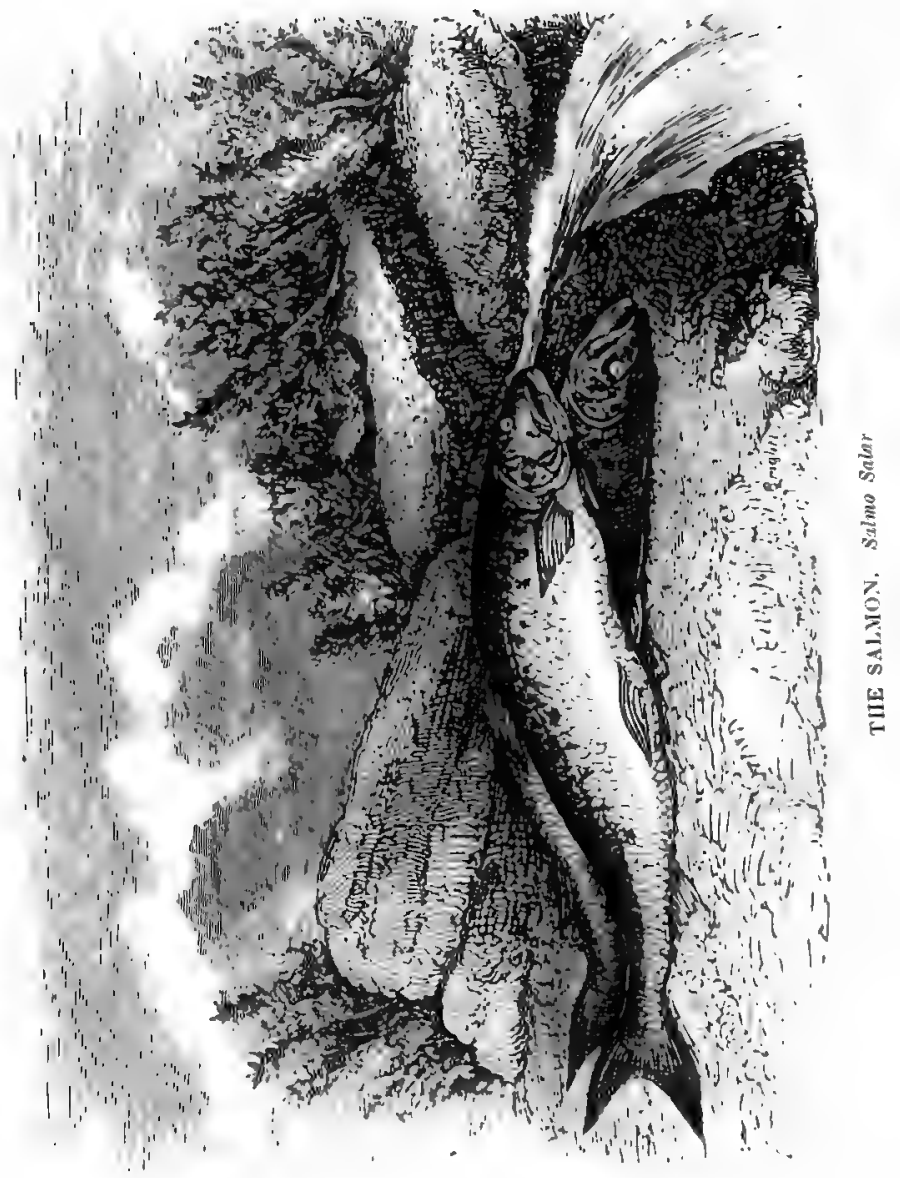




\section{THE SALMON.}

\section{Salmo Salar.}

Thrs glorious fellow, who is admitted on all hands to be the very king of fishes, as regards personal beauty, strength, agility, and speed, as regards excellence upou the table, and as regards the sport he gives to the vigorous and skillful angler, is in this month in his prime of health, vigor, and perfection, in all those waters of the United States and British Provinces, wherein he still exists. Within the limits of the former, on the Eastern or Atlantic side of the continent, those waters are confined to a few of the noble and limpid rivers in the State of Maine from the Kennebec, eastward, and to one or two large streams of Northern New York emptying into the St. Eavrence. In the British Provinces of New Bruaswick and Canada East, all the waters, whether emptying into the Bay of Fundy or the Gulf of St. Lawrence, are literally alive with this noble predatory fish, to such an extent that an accomplished fly-fisher, temporarily resident in the first-named province, "offered in 1850 to back himself, for any reasonable amount 
of bet, to kill with his own hand, three hundred salmon in that river"-the Nepisiguit discharging its waters into Bathurst Harbor-" during the month of July next ensuing." I quote from a letter of my friend Mr. Perley, the able and enterprising anthor of the "Sea and River Fisheries of New Brunswick," who adds, on his own account, "and with any reasonable luck as to weather, would readily win his bet. He took last season, before breakfast one day seventeen salmon; and I have heard of thirty being taken in a day by indifferent fishers."

Think of this, ye ambitious spirits, who casting deftly the long line and the winged deceit, pride yourselves on basketing your dozen or two of half-pound trout at Snedecor's or Carman's on the south side! Think of this-thirty salmon in a day with the fly, and that by indifferent fishers! Of a truth, the Nepisiguit, the Ristigonche, and the Miramichi, must be the paradise terrestrial, or aquatic rather, of the fly-fisher; nor is it so hard a region of attainment, for from Boston the good. steamer Admiral plies weekly to the city of St. John; and thence, on application to the good sportsman whose name I have recorded above, the pilgrim in pursuit of piscatorial glory, shall be right easily, and with a good will, forwarded upon his way.

But to return from this brief though not impertinent digression, although the salmon is so well known to all the dwellers of cities on the Atlantic coast as to require no description, yet for the benefit of inland sportsmen, 
and those especially, who, residing on the Susquehanna and the southerm rivers generally, fancy that they possess the salmon, in the glass-eye, or pike-perch, I shall proceed to insert a brief description of this beautiful glory of the rivers of all northern latitudes, alike on the Atlantic and Pacific oceans, and on the northern seas of Europe.

The salmon, fresh run from the sea, on his first entrance into the estuaries of the fresh rivers, up which le runs to deposit his spawn-of which more anon-is perhaps the most perfect in shape of all animals, and the most exquisite model of marine architecture in existence.

The proportions of one in perfect condition, and a large fish, are thus given by Sir Humphrey Davy, himself an eminent and eager fly-fisher, as well as a great waturalist and philosopher-the length $38 \frac{1}{2}$ inches-the circumference 21 inches, and the weight $22 \mathrm{lbs}$.

The head is small and sharponed, the body thence increasing gradually to about two-fifths of its length, at which point its girth is the greatest, with lines as shapely and a curvature as evenly and gracefully swelling as those of the entrance of the fleetest ship that ever walked the waters. Thence aftward, like the run of the same ressel, it tapers far more rapidly and sharply, the narrowest point being at four-fifths of its whole length, beyond which its broad, flat, deeply forked tail, the rudder at once and propeller of this wonderful animated rachine, expands to a width all but equal to that of the 
broadest portion of the body. The consequence of this exquisitely beautiful conformation is a combination of vigor, swiftness, and power of resistance to the element in which it exists equal to that of any known animal. The dart of the salmon in pursuit of its prey,: or its arrowy rush, on feeling the sting of the barbed hook, is comparable to nothing but the velocity of the swallow in the air. He runs up any rapids, it matters not how swift, or steep, or strong, of the mightiest rivers; with scarce an effort; he leaps all obstacles, whether of milldams or natural water-falls, not exceeding thirteen feet in perpendicular height, as easily as a trained hunter tops a quickset hedge; and, what is perhaps the most

- astonishing proof of his wonderful muscular strength, he can retain his station, head on in the teeth of a current, against which the strongest swimmer would not presume to struggle, motionless for many minutes together, at the end of which a slight and scarcely perceptible sweep of the powerful tail gives him, without sending him forward, the power of retaining his position, as before, for a similar interval of time.

When fresh from the sea, the upper part of his head, and all his body above the lateral line, are of a deep cerulean blue, almost black along the ridge, and mellowing downward into lustrous, pearly azure on the sides, the lower parts and belly glitter like burnished silver, and the whole fish appears, when newly taken from the water, to be cased in such silver and enameled mail, as 
we read of as worn by the tragic heroines of Tasso's or Aliosto's poetry.

A few irregular black spots scattered along the back and upper regions of his sides seem to set off by the contrast the brilliancy of his general coloring.

The structural peculiarities of the salmon, by which he is distinguished from all other families, are his sharp, strong, hooked teeth, and the number and formation of his fins. These latter are in number seven, exclusive of the tail-two dorsals, on the ridge of the back, the posterior of the two being a mere fatty appendage; two pectorals, immediately behind the gills; two ventrals on the sides of the belly about midway the length of the , fish; and one anal, midway between the ventrals and the under origin of the tail. The peculiarity in their formation is that they are all supported by soft-branched rays, as they are called, in opposition to the sharp and thorny spines, which are found more or less numerous in the dorsals, ventrals, and anals of many other families of fish-as the perch, the bass, and others, one of which is the fish known as the Ohio or Susquehanna salmon, but correctly named the pike-perch, or yellow sandre.

By the number and quality of his fins, therefore, the salmon family may be readily distinguished from all others; no other family having the hinder fatty dorsal fin.

By the number of rays in the several fins, the true salmon, or sea salmon, may be known from the others 
of his family, as the salmon-trout, or sea-trout, the spotted, or bruok-trout, the several varieties of lake-trout peculiar to the great inland waters of this country, and the many other more distantly connected species which it is unnecessary here to enumerate, though it may be well to state that the White fish of the lakes, the Otsego bass, the smelt, and the capelinn, are all of this family.

These fin rays in the true salmon are as follows: in the first dorsal, 15-second dorsal, 0-pectorals, each. 14-ventrals, each, 10-anal, 13-caudal fin, or tail, 21.

I have been more particular in dwelling on these particulars, because I am well aware that there are many good sportsmen throughout the country in the habit of miscalling many fishes, from ignorance of the true dis. tinctive marks, who will gladiy receive information which, as a general rule, can only be obtained from costly scientific works, out of the reach of the mass of men, and entirely unattainable in remote inland districts. A little attention to these distinctions would soon prit an end-to all the confusion now arising from the application of the same names to entirely different fishes in different sections of the country; even as a little attention to the habits and seasons of the finny, no less than of the feathery and fur-clad tribes, would tend at least to prevent their indiscriminate and cruel destruction at seasons when they are busy in the work of reproduction, and when, as it would seem by a special dispensation of Providence, they are unfit for the food of man. 
The salmon, properly speaking, is neither a salt-water nor a fresh-water fish; a change from one to the other, at different seasons of the year, being in his natural state necessary to his existence, and in any state to his greatest perfection. The salt water and the food which they therein obtain, the spawn, namely, and eggs of crabs, and other crustaceous fishes, are necessary to him for the recruiting and reinvigorating his system after the exhaustion consequeut on spawning; and to these he is supposed to owe his great and rapid growth, the deep ruddy color, and the exquisite flavor of his flesh.

The fresh water of clear, cold spring-fed rivers is necessary to him for the reproduction of his species, as it is now a proved and recognized fact, that the spawn, or eggs, of the salmon cannot be hatched or brought to life except in the highly aërated waters of clear, quickrunning, shallow, fresh streams.

If the upper parts of all the rivers in the world could be closed against the salmon, as in most of our own rivers they are by dams and weirs, the salmon would cease to exist at all, as they have ceased to exist in those rivers whence they are now excluded, but wherein they once abounded, us the Delaware, the Hudson, and the Connecticut, and thousands of others, even to the outlets of the small lakes of central New York, where they were once common.

In July the salmon begin freely to enter the estuaries of the breeding rivers, and after remaining for some 
weeks about the point where the tide turns, and salt and fresh water alternates, as if to acclimate themselves to the change of temperature, proceed up to the very headwaters of the streams they frequent, and there, in the gravelly bottoms of the shallow rivulets, deposit their eggs, to be matured and ripened by the effects of the air and sunshine. Thencé they descend to the sea again, to recover health and vigor for the ensuing season, but on their descent they would not be recognized for the same fish which ascended in the previous autumn, as they are now lean, flat-sided, big-headed-owing to the diminution of the body-dingy-colored, and utterly unfit for food. A male salmon, which from his length, should have weighed 11 lbs., in condition, being killed in this state, was found to weigh $4 \frac{1}{2} \mathrm{lbs}$. Yet in this miserable and useless state, as well as on the very spawning beds, when in the actual performance of their natural and paternal duties, this noble fish is ruthlessly and wantonly massacred to the gradual annihilation of the species, and to the extinction not only of an admirable and athletic sport, but of a considerable source of national wealth, and a valuable branch of domestic and foreign trade.

Now it is by no means necessary, either to abstain from taking salmon, in almost unlimited quantities at the proper season, that is to say, while they are running up the rivers in summer and early autumn, provided only that the whole channel is not obstructed by stake- 
nets, or to abolish mill-dams in toto, in order to prevent the destruction, and even insure the abundance of this noble fish in the waters whence it is so rapidly disappearing. Only abstain from killing it on the spawningbeds, when it is in the act of reproducing its kind, or when it is returning to the sea, weary and weak, and unfit for food-only compel, by strictly enforced law, every mill-dam owner to attach to his weir or dam, an apron, or sloping descent, of an angle not exceeding $45^{\circ}$, twelve feet in width, over which the water shall flow in a volume of one foot depth, and the fish will speedily be found in as great abundance as ever, in, all those waters from which he has not as yet wholly disappeared. Even in those where he is now extinct I believe that he could, be reproduced by the importation of small fry, and if reproduced, of course, preserved to any extent by the enforcement of proper laws. While on this subject, I would state, that greatly to the credit of the supervisors of that county, an act has been passed containing all the provisions above mentioned, with regard to the Salmon River, in Oswego county, I believe, in the State of New York; and I trust that the example thus set will be followed, with reference to the Oswego itself, and the Seneca, Cayuga, and Skaneateles outlets, in which case salmon would be once more taken in the heart of the Empire State, and instead of depending on Maine and New Brunswick for her supplies of salmon, New York would ere long be enabled to supply her $8^{*}$ 
sister cities on the seaboard with this high-priced and favorite dainty. It is singular that in the United States, where so much attention is given to every other form of industry, every other source of national wealth, so little has been paid to that very valuable resource, the sea and river fisheries.

But now to turn from the fish to the fishing. This sport is attainable on all salmon rivers above tide-water, or at about the meeting of the fresh and salt, by the sportsman, during the whole of the month of July and of August, and on some waters in the earlier part of September. There are but two ways of taking the salmon with the hook usually practiced by sporting fishermen, and one of these even rarely as compared with the other - the best, most scientific, most orthodox, and most successful, is casting with the artificial fly; the second, which will often kill good fish when the water is too foul, after heavy rains or freshets, to allow their rising to the fly, and at the meeting of the salt and fresh, is spinning or trolling with the minnow, the young trout in its parr state, the smelt, or the sand launce, occasionally in deep, still pools, the salmon will take a hook heavily shotted, and baited with two large dew-worms; and always and infallibly it will greedily seize one baited with its own roe potted and preserved with salt.

The former of these methods is, however, slow, uncertain, tedious, and inferior both as to sport and success to any of the rest. The latter is so deadly and unerring 
that it is regarded, by all true brother's of the rod and reel, in the same light as shooting birds on the ground would be by a genuine shot, as a pot-hunting, if not poaching device, unworthy of the sportsman.

I do not of course speak of kistering or spearing salmon, as that is an iniquity which can only be performed when the fish are spawning, practiced therefore neither by the true sportsman, nor the fair trader, but only by the greedy, wanton, destructive, cruel brute, who slaughters neither for legitimate sport nor for profit, but neerely for the wanton love of slaughtering. Nor do I speak of net fisheries, whether stake-net or seine, for these are the methods of capturing salmon for gain, not for sport or pleasure.

It is a singular thing that very little is known of the true food of the salmon; for so rapid is their digestion, that when taken their stomachs are always found empty, with the exception of a small quantity of yellowish fluid; but it would seem quite certain that while in fresh water it must consist principally, if not entirely, of small fish, for the natural water flies, which are the favorite food of trout and of themselves also when in their infancy, before they have visited salt water, they do not condescend to notice on their return to the rivers.

For what they mistake the large gaudy artificial salmon flies, at which they rise so greedily on their first advent into fresh water, it is impossible to conjecture; since there is nothing under heaven to which they bear 
even a distant resemblance. Sir Humphry Davy conjectures that they may be actuated by a vague local recollection, on returning, as they always do, to the identical rivers in which they were bred, from the sea, where they have been feeding on a totally different prey, of the water-flies which in their childhood they were used to take on the surface, and therefore looking to the surface for their food, strike at the first thing they see bearing a remote resemblance to a winged insect.

The implements necessary to the salmon fly-fisher are a powerful two-handed rod, of sixteen to eighteen feet in length, composed of ash, hickory and lancewood, or spliced bamboo, with a solid butt fitted with a spikewhereby to fix it in the ground erect while changing your flies or the like-a large click reel, on no account a multiplier, a hundred yards of hair line, a casting line of the stoutest, roundest and most even salmon gut, and a book of salmon-flies-the numbers, colors and varieties of which are endless.

As good as any, to my mind, is the peacock upper and blue-jay under wings, gay silk body, red hackle legs, and bird of Paradise tail ; but the truth is, that almost anything large and gaudy will take salmon, if deftly and skillfully dropped at the exact time, and in the exact place. If they will not take one they will another, and the which is which must be discovered by experiment.

The brighter and stiller the water, the smaller and 
more grave colored should be the fly, as a general rule. Where the river is foul, or the current much broken, foamy and rapid, the fly can hardly be too large, or too gaily colored.

For the rest, no writing can teach a man how to throw a fly, how to strike a fish when he has risen, or how to kill when he has struck him ; practice, patience, perseverance, and coolness are the great requisites, and the best way of learning is to accompany a good fly-fisher to the brook-side, to observe and study his motions, and by example more than by oral instruction to acquire his method, and by degees approach his skill.

I suppose hardly any one would attempt to use the double-handed rod, or attempt salmon, who had not first learned to throw a cast of flies from the light rod, and succeeded in hooking a trout. I will therefore merely observe, for the benefit of the trout fisher who makes his first essay on salmon, that it is not advisable, as in trout fishing, to keep the fly dancing as it were and hovering on the surface, but to let it sink a little way, pull it back with a slight jerk not quite out of water, and then let it sink again, and so on until your cast is finished, and you lift your fly for another. Again, when a salmon has risen at your fly, you need not strike near so quickly, and you must strike much more strongly and sharply than at a trout. Colquhoun; in his capital book, "The Moor and the Loch," recommends that the salmon be allowed to turn before striking him, and I 
think the advice sound and good. When he is struck you must make him fight for every inch of line yon give him, holding him very hard, but of course giving rather than letting him break you, until he becomes exhausted; if he plunges to the bottom and sulks, you must arouse him by stirring the water with a pole or pelting him with pebbles, for your "only chance of killing him depends," to borrow the words of Dary's Salmonia, " on his being kept constantly in action, so that he may exhaust himself by exercise."

When he is wearied out, when he turns up his broad; bright side exhausted on the surface, let your assistant pass the sharp, hooked gaff carefully under him, and strike it home by one cool, steady, upward jerk, and he is yours. Myself, I prefer to gaff in the solid muscnlar tail, behind the ventral cavity, as affording the best hold; but many good sportsmen prefer to strike in the shoulder. as giving more command of the fish-so that he i: gaffed, however, it matters not much where, for he is pretty certainly ashore a moment afterward. I may as well here mention that while on a visit in Truy recently, I was shown a new spring or click gaff, which must unquestionably supersede the old hook. It is easy of management, unerring, and can be handled with success by the most awkward country lad, and every sportsman knows how often he is annoyed by the clumsiness of an assistant who merely grazes a beaten fish, and goads him into fresh fury, perhaps causing his event 
ual loss, and eliciting naughty words from the not then gentle tisherman.

And now, kind reader mine, I liave told you whither to pass in pursuit of your sport; I have told you, so far as tell I can, how to rise, how to strike, how to kill, how to land your fish.

Now I will tell you how to cook him-eat him, I doubt not, you can without my teaching.

As soon as he is out of water stun him with a heavy blow on the head; then with a sharp knife crimp him, that is, gash him to the bone on both sides with a number of parallel transvere cuts, parallel to the line of the gills, at about two inches asunder; hold him up by the tail and let him bleed; cool him for ten minutes in the coldest spring or running water you can find at hand; carry him to the pot in which your salt and waternearly strong enough to bear an egg-must be boiling like mad; in with him, and let him boil quantum suff. Then serve him up, with no sauce save a few spoonsful of the water in which he was cooked, and if you please, the squeeze of a lemon, or, better yet, a lime-but, "an Jou love me, Hal," eschew the lobster sance, and the rich condiments, as Reading, Worcestershire or Soy, for he is rich enough withont, and they will but kill his natural flavor, and undo his delicacy.

And so adien, and good lnck to you! Take my advice, and when night cometh yon may boast that yon have fished well, and dined supremely. 
I may here add, for the information of whom it may concern, that my friend, Captain Peel, better known as Dinks, a famous sportsman and salmon fisher, has hired the exclusive fishing of one of the finest salmon rivers in Canada West, on which a good fisherman may bag from six to twenty well-fed fish per diem. The river affords admirable fishing for six or seven rod, is carefully preserved by Captain Peel, who keeps a regular gamekeeper on it; and is easily accessible from Quebec.

Captain Peel makes up a party to go thither and fish annually, furnishing all appliances and means to boot, lodging, after forest fashion, in comfortable shanties; - board of the best that can be obtained, including excellent port, sherry, and bottled ale; boats, men, everything in short, rods only excepted, that is requisite to the genuine sportsman, at the very small price of $\$ 120$ per month. The scenery of the Lower St. Lawrence is magnificent, the climate delicious, the fishing the finest in the world. The expense is ridiculously cheap as compared with the inducements offered, nor can I imagine a more delightful or cheaper mode of passing a couple of summer months than any sportsman can obtain by addressing Captain Peel, Amherstburg, Canada West. 


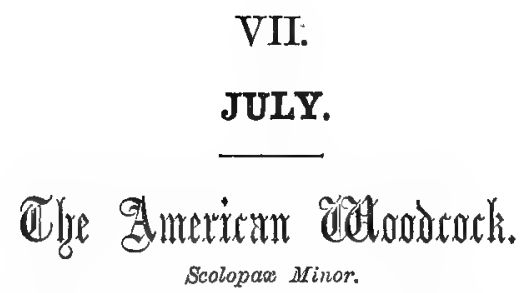

THE BLIND SNIPE; MUD SNIPE, \&c.

DURING THE SUMMER-CANADA TO VIRGINIA.

DURING THE WINTER-SOUTHERN STATES TO MEXICO 




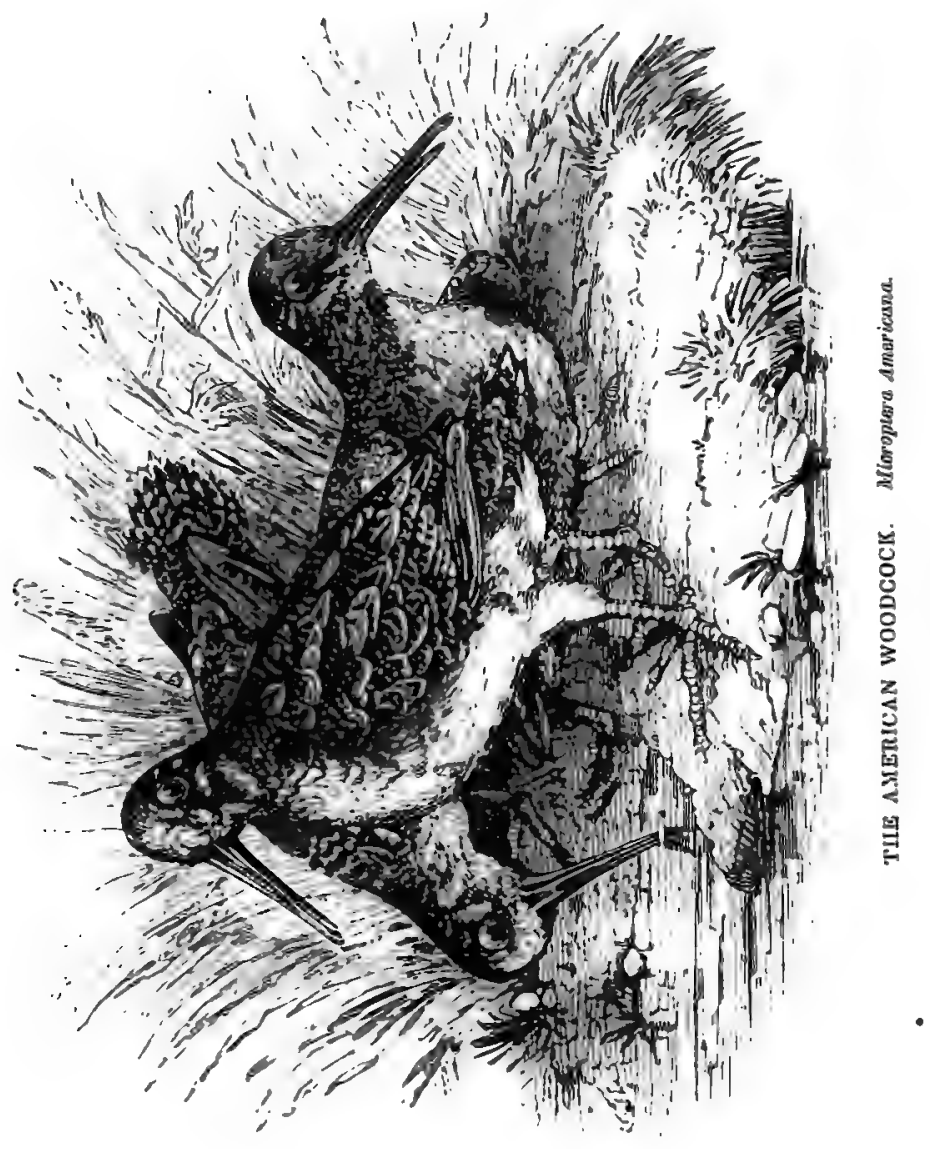




\section{THE AMERICAN WOODCOCK.}

\section{Scolopax Minor.}

Tere American Woodcock, Scolopax minor, or, as it has been subdistinguished by some naturalists, from the peculiar form of its short, rounded wing, the fourth and fifth quills of which are the longest, Microptera Americana, is, as the latter title indicates, exclusively confined to this hemisphere and continent. It is much smaller than its European namesake, being very rarely killed exceeding eight or nine ounces in weight, and sixteen inches in extent from tip to tip of the expanded wings; whereas the European cock averages full twelve ounces, being often found up to fifteen, and measures twenty-five or twenty-six inches.

In general appearance and color they bear a considerable affinity each to the other; the upper plumage of both being beautifully yariegated, like the finest tortoiseshell, with wary black lines on a rich brown ground, mottled in places with bright fawn color and ash-gray, but the breast and belly of the American bird are of a deep fulvous yellow, darkest on upper part and fading to 
a yellowish white at the vent, while its European congener has all the lower parts of a dull cream color, barred with faint dusky waved lines, like the breast feathers of some of the falcons.

It has generally been believed that the large cock of the Eastern continent is never found in America; and all analogy would go to strengthen that belief, for neither of the birds range on their respective continents very far to the northward, whereas it is those species only which extend into the Arctic regions, and by no means all of them, that are common to the two hemispheres. Some circumstances have, however, come recently to my knowledge which lead me to doubt whether the large woodcock of the Eastern hemisphere does not occasionally find its way to this continent, although it is difficult to conceive how it should do so, since it must necessarily wing its way across the whole width of the Atlantic, from the . shores of Ireland or the Azores, which are, so far as is ascertained, its extreme western limit.

A very good English sportsman resident in Philadelphia, who is perfectly familiar with both the species and their distinctions, assures me that during the past winter a friend brought for his inspection an undoubted English woodcock, which he had purchased in the market; it weighed twelve ounces, measured twenty-five inches from wing to wing, and had the cream-colored barred breast which I have described. The keeper of the stall at which this bird was purchased did not know where it 
had been killed, but averred that several birds had previously been in his possession, precisely similar to this in every respect. It is not a little remarkable that the same gentleman who saw this bird, and unhesitatingly pronounced it an European cock, was informed by a sporting friend that he had seen in Susquehanna county a cock, which he was satisfied must have measured twenty-five inches in extent, but which he unfortunately missed. There is likewise, at this time, in the city a skull and bill of a woodcock of very unusual dimensions, of which I am promised a sight, and which, from the description, I am well nigh convinced is of the European species.

It is possible that these birds may have been brought orer and kept in confinement, and subsequently escaped, and so become naturalized in America; and yet it is difficult to conceive that persons should have taken the trouble of preserving so stupid and uninteresting a bird as the woodcock in a cage, unless for the purpose of transporting them from one country to another in order to the introduction of new species.

This might be done very easily with regard to some species, and with undoubted success; and it has greatly surprised me that it has never been attempted with regard to our American woodcock, which might unquestionably be naturalized in England with the greatest - facility; where it would, I have no doubt, multiply extraordinarily, and become one of the most numerous 
and valuable species of game, as the mildness of the -winters in ordinary seasons would permit the bird to remain perennially in the island, without resorting to migration in order to obtain food.

The woodcock and snipe can both be very readily domesticated, and can easily be induced to feed on bread and milk reduced to the consistency of pulp, of which they ultimately become extremely fond. This is done at first by throwing a few small red worms into the bread and milk, for which the birds bore and bill, as if it were in their natural muddy soil.

In all countries in which any species of the woodcock is found, it is a bird essentially of moderate climates, abhorring and shunning all extremes of temperature, whether of heat or of cold.

With us, it winters in the Southern States from Virginia, in parts of which, I believe, it is found at all seasons of the year, through the Carolinas, Georgia and Florida to Louisiana and Mississippi, in the almost impenetrable cane-brakes and deep morasses of which it finds a secure retreat and abundance of its favorite food, during the inclement season, which binds up every stream and boggy swamp of the Middle and New England States in icy fetters.

So soon, however, as the first indications of spring commence, in those regions of almost tropical heat, the woodcock wings its way with the unerring certainty of instinct which guides him back, as surely as the magnet 
points to the pole, to the very wood and the very brake of the wood in which he was hatched, and commences the duties of nidification.

I am inclined to believe that the woodcock are already paired when they come on to the northward; if not, they do so without the slightest delay, for they unquestionably begin to lay within a week or two after their arrival, sometimes even before the snow has melted from the upland. Sometimes they have been known to lay so early as February, but March and the beginning of April are their more general season. Their nest is very inartificially made of dry leaves and stalks of grass. The female lays from four to five eggs, about an inch and a half long, by an inch in diameter, of a dull clay color, marked with a few blotches of dark brown interspersed with splashes of faint purple. It is a little doubtful whether the woodcock does or does not rear a second brood of young, unless the first hatching is destroyed, as is very frequently the case, by spring floods, which are very fatal to them. In this case, they do unquestionably breed a second time, for I have myself found the young birds, skulking about like young mice in the long grass, unable to fly, and covered with short blackish down, the most uncouth and comical looking little wretches imaginable, during early July shooting; but it is on the whole my opinion that, at least on early seasons, they generally raise two broods and this, 
among others, is one cause of nay very strong desire to see summer woodcock shooting entirely abolished.

Unless this is done, I am convinced beyond doubt, that before twenty years have elapsed the woodcock will be as rare an animal as a wolf between the great lakes and the Atlantic sea-board, so ruthlessly are they persecuted and hunted down by pot-hunters and poachers, for the benefit of restaurateurs and of the lazy, greedy cockneys who support them. There is, however, I fear, little hope of any legislative enactment toward this highly desirable end; for too many even of those who call themselves, and who ought to be, true sportsmen, are selfish and obstinate on this point, and the name of the pot-hunters is veritably legion. Moreover, it is to be doubted whether, even if such a statute were added to our game-laws, it could be enforced; so vehemently opposed do all the rural classes, who ought to be the best friends of the game, show themselves on all occasions to any attempt toward preserving them, partly from a mistaken idea that game-laws are of feudal origin and of aristocratic tendency; and so averse are they to enforce the penalties of the law on offenders, from a servile apprehension of giving offense to their neighbors.

At present, in almost all the States of which the woodcock is a summer visitant, either by law or by prescription, July is the month appropriated to the commencement of their slaughter; in New York the first is the 
day, in New Jersey the fifth, and in all the Middle States, with the single exception of Delaware, where it is deferred until August, some day of the same month is fixed as the termination of close time. Even in Delaware the exception is rendered nugatory, by a provision permitting every person to shoot on his own grounds, whether in or ont of season, in consequence of which the birds are all killed off early in June.

It may now be set down almost as a rule, that in all the Atlantic seaboard counties, and, indeed, every where in the vicinity of the large cities and great thoroughfares, the whole of the summer hatching is killed off before the end of July, with the exception of a few scattered stragglers, which have escaped pursuit in some impenetrable brake or oozy quagmire which defles the foot of the sportsman; that few survive to moult, and that the diminished numbers, which we now find on our autumn shooting-grounds, are supplied exclusively by the northern and Canadian broods, which keep successively flying before the advancing cold of winter, and sojourning among us for a longer or a shorter period, ere they wing their way to the rice-fields of the Savannah, or the cane-brakes of the Mississippi.

If my method could be generally adopted, of letting the fifteenth day of September, after the moulting season is passed, and when the birds are beginning again to congregate on their favorite feeding-grounds, be the commencement of every sort of upland shooting, with- 
out any exception, the sport would be enormous; the birds at that season are in full vigor, in complete plumage, in the perfection of condition for the table, and are so strong on the wing, so active and so swift, that no one could for a moment imagine them to be the same with the miserable, puny, half-fledged younglings, which any bungling boy can butcher as he pleases, with the most miserable apparatus, and without almost as well as with a dog, during the dog-days of July.

The weather is, moreover, cool and pleasanit, and in every way well-suited to the sport at this season; dogs have a chance to do their work handsomely and well, and the sportsman can do his work, too, as he ought to do it, like a man, walking at his proper rate, unmolested by mosquitoes, and without feeling the salt perspiration streaming into his eyes, until he can hardly brook the pain.

But no such hope existing as that state legislatures, dependent, not on rational but on brute opinion, should condescend to hear or listen to common sense, on matters such as game laws, are we, or are we not, to abandon our plan, to sacrifice our knowledge and enlightened views on this subject to obstinate ignorance; or shall we not take the better part, and decide, according to Minerva's lesson in Tennyson's magnificent Anone,

- . For that right is right to follow right

Where wistom is the scorn of consequence. 
We shall resist and persist; at least I shall-I, Frank Forester, who never in my life have killed a bird out of season intentionally, and who never will-who am compelled by sham sportsmen, cockney and pot-gunners to shoot woodcock in July; who have been invited, times out and over again, to shoot cock on men's own ground, and therefore within the letter of the law, in New Jersey, Pennsylvania, Delaware, and Maryland, before the season; who have ever refused to take the advantages, which every one takes over me; and who still intend to persist, though not to hope, that there may be sense enough, if not integrity, among the legislatures of the free states, to prevent the destruction of all game within their several jurisdictions.

As the thing stands-and by the thing I mean the law -woodeock are to be shot on or about the first day of July; and if, dear reader, you try to shoot any where within fifty miles of New York, or twenty-five of Philadelphia, much later than the tenth of June, I am inclined to think that you will find wonderfully little sport; before the season, do not fire a shot, if you will take my advice; if poachers will violate the law, and the law will not enforce itself against poachers, abstain from becoming a poacher yourself, and do not shoot before the season fairly commences.

At this period of the year woodcock are almost invariably found in the lowlands ; sometimes, as, for instance, at Salem, in New Jersey, and many other similar locali- 
ties along the low and level shores of the Delaware, in the wide, open meadows, where there is not a bush or brake to be seen for miles; but more generally in low, swampy woods, particularly in maple woods, which have an undergrowth of alder; along the margin of oozy streamlets, creeping through moist meadows, among willow thickets; and in wet pastures trampled by cattle, and set here and there with little brakes, which afford them shade and shelter during the heat of the day.

Of the latter description is the ground, once so famous for its summer cock-shooting, known as "the drowned lands," in Orange County, New York, extending for miles and miles along the margins of the Wallkill and its tributaries, the Black Creek, the Quaker Creek, and the beautiful Wawayanda. Many a day of glorious sport have I had on those sweet level meadows, enjoyed with friends long since dispersed and scattered, some dead, untimely, some in far distant lands, some falseand some forgetful, and thou, true-hearted, honest, merrybrave, Tom Draw; thou whilom king of hosts and emperor of sportsmen, thou, saddest fate of all, smitten, or ere thy prime was passed away, by the most fearful visitation that awaits mankind-the awful doom of blindness! never again shall I draw trigger on those once loved levels-the railroad now thunders and whistles close beside them, and every man and boy and fool, now sports his fowling-piece; and not a woodcock on the meadows but, after running the gauntlet of a 
hundred shots, a hundred volleys, is consigned to the care of some conductor, by him to be delivered to Delmonico or Florence, for the benefit of fat, greasy merchant-princes; and if it were not so, if birds, swarmed as of yore in every reedy slank, by every alderbrake, in every willow tuft, the ground is haunted by too many recollections, rife with too ntany thick-succeeding memories to render it a fitting place, to me at least, for pleasurable or gay pursuits.

But, as I have said before, summer cock-shooting on the Drowned Lands of Orange County is among the things that have been-one of the stars that have set, never to be relumed, in the nineteenth century; and the glory of "the Warwick Woodlands" has departed.

In Connecticut, in some parts, there is very good summer cock-shooting yet; and also in many places in the neighborhood of Philadelphia, in the rich alluvial levels around the Delaware, the Schuylkill, and their tributary rivers; but the sportsman, who really thirsts for fine shooting-shooting such as it does the heart good to hear of-must mount the iron-horse, whose breath is the hissing steam, and away, fleeter even than the wings of the morning, for Michigan and Illinois and Indiana, for the willow-brakes of Alganac, and the rice-marshes of Lake St. Clair; and there he may shoot cock till his gun-barrels are red-hot, and his heart is satiate of birdslaughter.

It is usual at this season to shoot cock over pointers or 
setters, according to individual preference of this or that race of dogs; for myself, of the two, I prefer the setter, as in cock-shooting there is always abundance of water to be had, and this rough-coated, high-strung dog can face brakes and penetrate coverts, which play the mischief with the smooth satiny skin of the high.blooded pointer.

In truth; however, neither of these, but the shortlegged, bony, red and white cocking-spaniel, is the true dog over which to shoot summer woodcock; and no one, I will answer for it, who has ever hunted a good ciry of these, will ever again resort either to setter or pointer for this, to them, inappropriate service.

The true place for these dogs is the open plain, the golden stubble, the wide-stretching prairie, the highland, moor, where they can find full scope for their heady courage, their wonderful fleetness, their unwearied industry, and display their miracles of staunchness, steadiness, and nose.

In order to hunt these dogs on cock, you must unteach them some of their noblest faculties, you must tame down their spirits, shackle their fiery speed, reduce them, in fact, to the functions of the spaniel, which is much what it would be to train a battle charger to bear a pack-saddle, or manage an Eclipse into a lady's ambling palfrey.

The cocking-spaniel, on the contrary, is here in his very vocation. Ever industrious, ever busy, never rang- 
ing above twenty paces from his master, bustling round every stump, prying into every fern-bush, worming his long, stout body, propped on its short, bony legs, into the densest and most matted cover, no cock can escape him.

See! one of them has struck a trail; how he flourishes his stump of a tail. Now he snuffs the tainted ground; what a rapture fills his dark, expressive eye. Now he is certain; he pauses for a moment, looks back to see if his master is at hand; "Yaff! yaff!" the brakes ring with his merry clamor, his comrade rushes to his aid like lightning, yet pauses ever, obedient to the whistle, nor presses the game too rashly, so that it rise out of distance. Up steps the master, with his thumb upon the dexter hammer, and his fore-finger on the trigger-guard. * Now they are close upon the quarry; "yaff! yaff! yaff!" Flip flap! up springs the cock, with a shrill whistle, on a soaring wing. Flip flap ! again-there are a couple. Deliberately prompt, up goes the fatal tubeeven as the butt presses the shoulder, trigger is drawn after trigger. Bang! bang! the eye of faith and the finger of instinct have.done their work, duly, truly. The thud of one bird, as he strikes the moist soil, tells that he has fallen; the long stream of feathers floating in the still air through yonder open glade, announces the fate of the second; and, before the butt of the gun, dropped to load, has touched the ground, without a word or question, down charged at the report, the busy little 
babblers are couched silent in the soft, succulent young grass. Loaded once more, "Hie! fetch !" and what a race of emulation-mouthing their birds gently, yet rapturously, to inhale best the delicate aroma, not biting them, each cocker has brought in his bird, and they and you, gentle reader, if you be the happy sportsman who possesses such a brace of beauties, are rewarded adequately and enongh.

For, the rest, a short, wide-bored, double-barrel, an ounce of No. 8 shot, and an equal measure of Brough's diamond-grain, will do the business of friend microptera, as effectually, at this season, as a huge, long, old-fashioned nine-pounder, with its two ounce charge; and it will give you this advantage, that it shall weigh less by three pounds, and enable you to dispense with a superfluous weight of shot, which on a hot July day, especially if you be at all inclined to what our friend Willis calls pinguitude, will of a necessity produce much exudation, and some lassitude. 


\section{VIII. \\ AUGUST.}

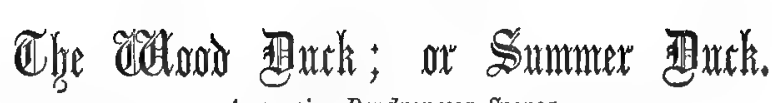
Anas, sivo Dendronessa Sponsa,

THE UNITED STATES; CANADA TO MEXICO.

\section{Che Ammericalr 整eet. Cervus Viroinianus.}

AMERICAN CONTINENT-NEW BRUNSWICK TO MEXICO. 




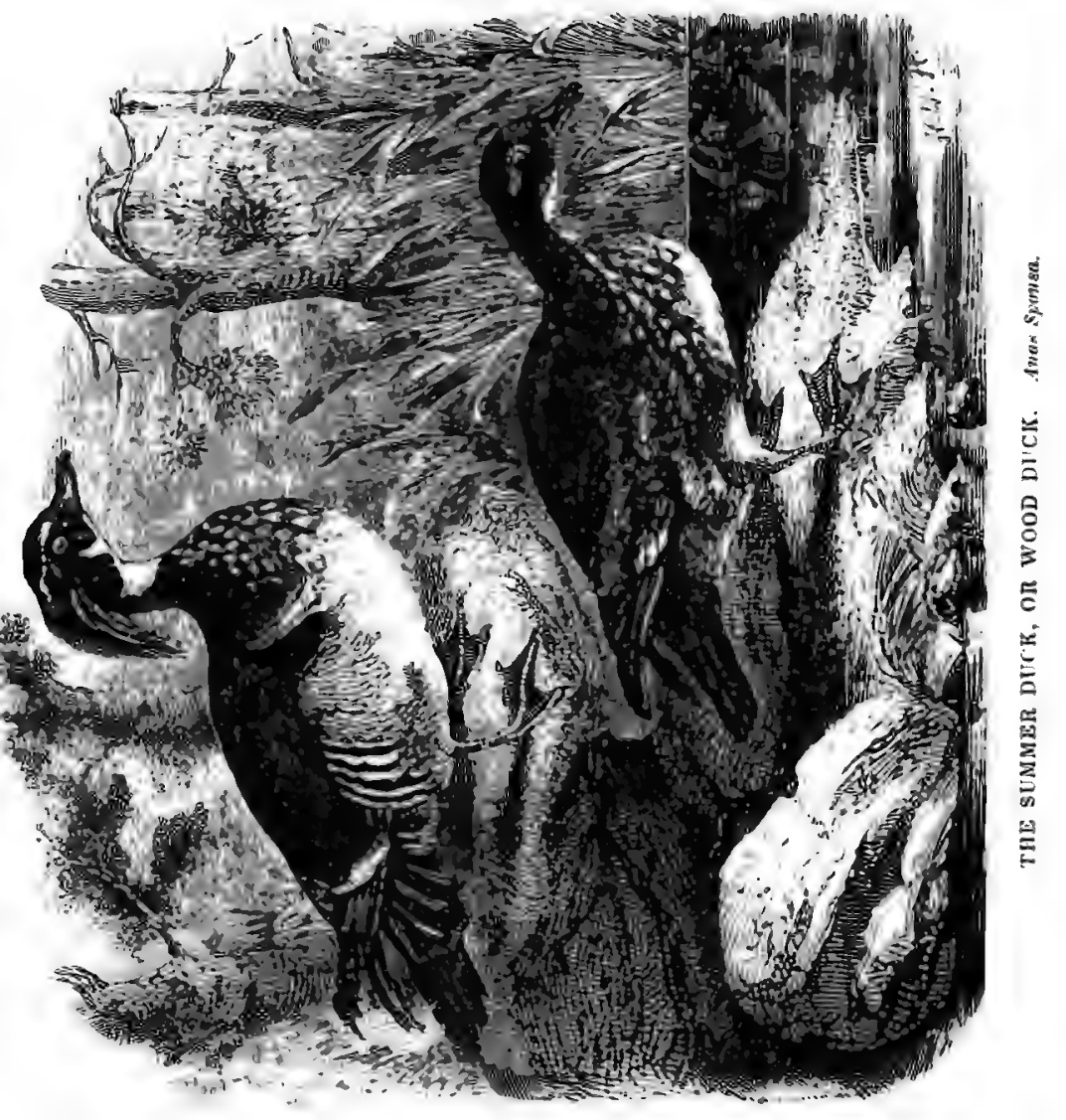




\section{THE SUMMER DUCK, OR WOOD DUCK. Anas Sponsa.}

This lovely species of the most beautiful of the whole Duck tribe, is peculiar to the continent and isles of America, being familiarly known through almost every portion of the United States, and according to Wilson, common in Mexico and the West India Islands. In Florida it is very abundant, as it is, more or less, on all the fresh waters so far north as the interior of the State of New York; in the colder regions, to the north-eastward, though not unknown, it is of less frequent occurrence than in more genial climates.

Its more correct title, "Summer Duck," is referable to the fact, that it is not, like most of the Anatides and Fuligulos, fresh water and sea ducks, more or less a bird of passage, retiring to the fastnesses of the extreme north, for the purposes of nidification, and rearing its young; but, wherever it abounds, is a permanent citizen of the land, raising its family in the very place where itself was born, and not generally, if undisturbed, moving very far 
from its native haunts. I think, however, that in the United States it is perhaps better known under its other appellation of Wood Duck; and I am not prepared to say, although the former is the specific name adopted by all naturalists, that the latter is not the better, as the more distinctive title, and applying to a more remarkable peculiarity of the bird. For it, alone, so far as I know, of the Duck family, is in the habit of perching and roosting on the upper branches of tall trees, near water-courses, and of making its nest in the holes and hollows of old trunks, overhanging sequestered streams or woodland pools, often at a great height above the surface of the water.

The Summer Duck is the most gayly attired of the whole family; it has, moreover, a form of very unusual elegance, as compared with other ducks; and a facility of flight, and a command of itself on the wing, most unlike to the ponderous, angular flapping of the rest of its tribe, wheeling with a rapidity and power of pinion, approaching in some degree to that of the swallow, in and out among the branches of the gnarled and tortuous pinoaks, whose shelter it especially affects.

From two very fine specimens, male and female, now before me, I take the following description :

Drake, in full summer plumage. Length from tip of bill to tip of tail, 21 inches. Length of wing, 9 inches. Bill, 1 1-5 inch. Tarsus, $1 \frac{1}{2}$. Middle toe, 2 inches. Body long, delicately shaped, rounded. Head small, finely 
crested; neck rather long and slender. Eye large, with golden-yellow irides. Legs and feet orange-yellow, webs dusky, claws black. Plumage soft, compressed, blended. Bill orange-red at the base, yellow on the sides, with a black spot above the nostrils, extending nearly to the tip ; nail recurved, black.

The colors are most vivid. The crown of the head, cheeks, side of the upper neck and crest changeable, varying in different lights, from bottle-green, through all hues of dark blue, bright azure, purple, with ruby and amethyst reflections, to jet black. From the upper corner of the upper mandible a narrow snow-white streak above the eye runs back, expanding somewhat, into the upper crest. A broader streak of the same extends backward below the eye, and forms several bright streaks in the lower part of the crest. Chin and fore throat snow-white, with a sort of double gorget, the upper" extending upward a little posterior to the eye, and nearly reaching it, the lower almost encircling the neck at its narrowest part. The lower neck and upper breast are of the richest vinous red, interspersed in front with small arrow-headed spots of pure white. Lower breast white, spotted with paler vinous red; belly pure white. Scapulars, and lower hind neck, reddish brown, with green reflections. Back, tail-coverts and tail black, splendidly glossed with metallic lustre of rich blue-green and purple. Wing-coverts and primaries brown, glossed with blue and green, outer webs of the primaries silvery 
white; secondaries glossy blue-black. A broad crescentshaped band of pure white in front of the wings, at the edge of the red breast-feathers, and behind this a broader margin of jet black. The sides of the body rich greenish yellow, most delicately peneiled with narrow close waved lines of gray. On the flanks six distinct semi-lunated bands of white, anteriorly bordered with broad black origins, and tipped with black. The vent tawny white, the rump and under tail-coverts dark reddish purple.

The duck is smaller and duller in her general coloring; but still bears sufficient resemblance to the splendid drake to cause her at once to be recognized, by any moderately observant eye, as his mate.

Her bill is blackish brown, the irides of her eyes hazel brown, her feet dull dusky green. Crown of her head and hind neck dusky, faintly glossed with green, and with the rudiments of a crest; cheeks dusky brown. A white circle round the eye and longitudinal spot behind it. Chin and throat dingy white. Shoulders, back, scapulars, wing-coverts, rump and tail brown, more or less glossed with green, purple and dark crimson. Primaries black, with reflections of deep cerulean blue and violet; outer webs silvery white. Secondaries violetblue and deep green, with black edges and a broad white margin, forming the speculum or beauty spot. Upper fore neck, breast, sides and flanks deep chestnut-brown, spotted in irregular lines with oval marks of faint tawny 
yellow; belly, vent and under tail-coverts white, flanks and thighs dull brown.

The young males of the first season are scarcely distinguishable from the ducks.

The Summer Duck breeds, in New York and New Jersey, according to the season, from early in April until late in May; in July the young birds are not much inferior in size to the parents, though not yet very strong on the wing. I well remember on one occasion, during the second week of that month, in the year 1836, while out woodcock shooting near Warwick, in Orange county, New York, with a steady brace of setters, how some mowers who were at work on the banks of the beautiful Wawayanda, hailed me, and, pointing to a patch of perhaps two acres of coarse, rushy grass, told me that six ducks had just gone down there. I called my dogs to heel, and walked very gingerly through the meadow, with finger on the trigger, expecting the birds to rise very wild; but to my great surprise reached the end of the grass, on the rivulet's margin, without moving any thing.

The men still persisted that the birds were there; and so they were, sure enough; for on bidding my setters hold up, I soon got six dead points in the grass, and not without some trouble kicked up the birds, so hard did they lay. It was a calm, bright summer's day, not a duck rose above ten feet from me, and I bagged them all. They proved to be the old duck and five young birds of 
that season, but in size the latter were quite equal to the mother bird.

I consider the Summer Duck at all times rather a less shy bird than its congeners, though it may that it is owing to the woody covert which, unlike other's of its tribe, it delights to frequent; and which perhaps acts in some degree as a screen to its pursuer; but except on one other occasion I never saw any thing like the tameness of that brood.

The other instance occurred nearly in the same place, and in the same month, I think, of the ensuing year. I was again out summer cock shooting, and was crossing a small, sluggish brook, of some twelve or fourteen feet over, with my gun under my arm, on a pile of old rails, which had been thrown into the channel by the haymakers, to make an extemporaneous bridge for the hay teams; when on a sudden, to my very great wonderment, and I must admit to my very considerable flusteration likewise, almost to the point of tumbling me into the mud, out got a couple of Wood Ducks from the rails, literally under my feet, with a prodigious bustle of wings and quacking. If I had not so nearly tumbled into the stream, ten to one I should have shot too quickly and missed them both; but the little effort to recover my footing gave me time to get cool again, and I bagged them both. One was again the old duck, the other a young drake of that season.

In the spring, the old duck selects her place in some 
snug, unsuspicious looking hole in some old tree near the water edge, where, if unmolested, she will breed many years in succession, carrying down her young when ready to fly, in her bill, and placing them in the water. The drake is very attentive to the female while she is laying, and yet more so while she is engaged in the duties of incubation; constantly wheeling abont on the wing among the branches, near the nest on which she is sitting, and greeting her with a little undertoned murmur of affection, or perching on a bough of the same tree, as if to keep watch over her:

The following account of their habits is so true, and the anecdote illustrating them so pretty and pleasing, that I camnot refrain from quoting it, for the benefit of those of my readers who may not be so fortunate as to have cultivated a familiar friendship with the pages of that eloquent pioneer of the natural history of the woods and wilds and waters of America, the Scottish Wilson, who has done more for that science than any dead or living man, with the sole exception of his immortal successor, the great and good Audubon; and whose works will stand side by side with his, so long as truthfulness of details, correctness of classification, eloquence of style, and a pure taste and love for rural sounds and sights shall command a willing audience. Speaking of this bird he says-

"It is familiarly known in every quarter of the United States, from Florida to Lake Ontario, in the neighbor- 
hood of which latter place I have myself met with it in October. It rarely visits the sea-shore, or salt marshes, its favorite haunts being the solitary, deep, and muddy creeks, ponds and mill-dams of the interior, making its nest frequently in old hollow trees that overhang the water.

"The Summer Duck is equally well krown in Mexico and many of the West India Islands. During the whole of our winters they are occasionally seen in the states south of the Potomac. On the 10th of January I met with two on a creek near Petersburgh, in Virginia. In the more northern districts, however, they are migratory. In Pennsylvania the female usually begins to lay late in April, or early in May. Instances have been known where the nest was constructed of a few sticks laid in a fork of the branches; usually, however, the inside of a hollow tree is selected for this purpose. On the $18 \mathrm{th}$ of May I visited a tree containing the nest of a Summer Duck, on the banks of the Tuckahoe River, New Jersey. It was an old, grotesque white-oak, whose top had been torn off by a storm. It stood on the declivity of the bank, about twenty yards from the water. In this hollow and broken top, and about six feet down, on the soft, decayed wood, lay thirteen eggs, snugly covered with down, doubtless taken from the breast of the bird. These eggs were of an exact oval shape, less than those of a hen, the surface exceedingly fine grained, and of the highest polish, and slightly yellowish, greatly resem- 
bling old polished ivory. The egg measured two inches and an eighth by one inch and a half. On brealing one of them, the young bird was found to be nearly hatched, but dead, as neither of the parents had been observed about the tree during the three or four days preceding, and were conjectured to have been shot.

"This tree had been occupied, probably, by the same pair, for four successive years, in breeding time; the person who gave me the information, and whose house was within twenty or thirty yards of the tree, said that he had seen the female, the spring preceding, carry down thirteen young, one by one, in less than ten minutes. She caught them in her bill by the wing or back of the neck, and landed them safely at the foot of the tree, whence she afterward led them to the water. Under this same tree, at the time I visited it, a large sloop lay on the stocks, nearly finished; the deck was not more than twelve feet distant from the nest, yet notwithstanding the presence and noise of the workmen, the ducks would not abandon their old breeding place, but continued to pass out and in, as if no person had been near. The male usually perched on an adjoining limb, and kept watch while the female was laying, and also often while she was sitting. A tame goose had chosen a hollow space at the root of the same tree, to lay and hatch her young in.

"The Summer Duck seldom flies in flocks of more than three or four individuals together, and most com- 
monly in pairs, or singly. The common note of the drake is peet, peet; but when, standing sentinel, he sees danger, he makes a noise not unlike the crowing of a young cock, oe eek! oe eek! Their food consists principally of acorns, seeds of the wild oats, and insects."

Mr. Wilson states, as his opinion, that the flesh of this lovely little duck is inferior in excellence to that of the blue-winged teal. But therein I can by no means coincide with him, as I consider it, in the Atlantic states, inferior to no duck except the canvas-back, which is admitted facile princeps of all the duck tribe. The Summer Duck is in these districts probably the most graminivorous and granivorous of the family, not affecting fish, tadpoles, frogs or field-mice, all of which are swallowed with great alacrity and rejoicing by the mallards, pintails, and other haunters of fresh water streams and lakes.

On the great lakes of the west and north, where all the duck tribe feed to fattening on the wild rice and wild celery, zizania aquatica and balisneria Americana, no one species is better than another, all being admirable; but in the course of an autumn spent on the northern shores of Lake Huron and the rivers debouching into it, and thence north-westward to Lake Superior, I do not remember seeing any specimens of this beautiful bird, though I feel sure that it cannot but exist in those waters, which are in all respects so congenial to its habits.

Another peculiarity of this species, which I have 
repeatedly noticed, when it has not been disturbed by any sudden noise or the pursuit of dogs, is thus neatly touched upon by Mr. J. P. Giraud, Jr., the enthusiastic and accomplished ornithologist of Long Island, whose unpretending little volume should be the text book of every sportsman in the land who has a taste for any thing beyond mere wanton slaughter.

"Often when following those beautiful and rapid streams that greatly embellish our country, in pursuit of the angler's beau ideal of sport, have I met with this gayly-attired duck. As if proud of its unrivalled beauty, it would slowly rise and perform a circuit in the air, seemingly to give the admiring beholder an opportunity of witnessing the gem of its tribe."

The Summer Duck is very easily domesticated, if the eggs be taken from the nest and hatched under a hen, and the young birds become perfectly tame, coming up to the house or the barn-yard to be fed, with even more regularity than the common domestic duck; nay, even the old birds, if taken by the net and wing-tipped, will soon become gentle and lose their natural shyness.

In the summer of $1843 \mathrm{I}$ had the pleasure of seeing a large flock of these lovely wild fowl perfectly gentle, answering the call of their owner by their peculiar murmur of pleasure, and coming, as fast as they conld swim. or run, to be fed by his hand.

This was at the beautiful place of the Hon. Mahlon Dickinson, formerly a member of General Jackson's cabi- 
net, not far from Morristown, in New Jersey, which is singularly adapted for the rearing and domesticating these ferce natur $\hat{a}$; since it has, immediately adjoining the trim and regular gardens, a long and large tract of beantiful wild shrubbery, full of rare evergreens, and interspersed with bright; cool springs and streamlets feeding many ponds and reservoirs, where they can feed, and sport, and breed, as undisturbed as in the actual wilderness; while the adjacent country being all tame and highly cultivated, they have no inducement to stray from their abode.

Beside Summer Ducks, Mr. Dickinson had at the period of my visit, Dusky Ducks, better known as Black Ducks, Green-winged Teal, Golden-eyes, and, I think, Widgeon; but the Summer Ducks were by far the tamest, as the Dusky Ducks were the wildest of the company. I should long ago have attempted to naturalize them on my own place, but that a large river, the Passaic, washing the lower end of my lawn and garden, from which it would not be possible to exclude them, I have felt that it is useless to attempt it, the rather that there is a large patch of wild-rice immediately adjoining me, which would tempt them to the water, whence they would drift away with the current or the tide, and be lost or shot in no time.

The best time for shooting and for eating these fowl is late in October, when the acorns and beech-mast, of both of which they are inordinately fond, lie thick and ripe 
on the woodland banks of the streams and pools they love to frequent. And this reminds me of a little sketch, illustrative of their habits, taken down almost verbatim, from the lips of a right good fellow, and at that time a right good sportsman also; though now, alas! the untimely loss of the inestimable blessing of eyesight has robbed him, among other sources of enjoyment, of that farorite and innocent pastime-the forest chase:

"Are there many Wood Ducks about this season, Tom ?" asked Forester, affecting to be perfectly careless and indifferent to all that had passed. "Did you kill these yourself?"

"There was a sight on them a piece back, but they're gittin' scase-pretty scase now, I tell you. Yes, I shot these down by Aunt Sally's big spring-hole a Friday. I'd been a lookin' round, you see, to find where the quail kept afore you came up here-for I'd a been expectin' you a week and better-and I'd got in quite late, toward sundown, with an outsidin' bevy, down by' the cedar swamp, and druv "them off into the big bog meadows, below Sugarloaf, and I'd killed quite a bunch on them - sixteen, I reckon, Archer; and there was n't but eighteen when I lit on em'-and it was gittin' pretty well dark when I came to the big spring, and little Dash was worn dead out, and I was tired, and hot, and thunderin' thirsty, so I sets down aside the outlet where the spring water comes in good and cool, and I was mixkin' up a nice, long drink in the big glass we hid last sum- 
mer down in the mud-hole, with some great cider sperrits-when what should I hear all at once but whistle, whistlin' over head, the wings of a whole drove on 'em, so up I buckled the old gun; but they'd plumped down into the crick fifteen rod off or better, down by the big pin oak, and there they sot, seven ducks and two big purple-headed drakes-beauties, I tell you. Well, boys, I upped gun and tuck sight stret away, but just as I was drawin', I kind o' thought I'd got two little charges of number eight, and that to shoot,at ducks at fifteen rod was n't nauthen. Well, then, I fell a thinkin', and then I sairched my pockets, and arter a piece found two green cartridges of number three, as Archer gave me in the spring, so I drawed out the small shot, and inned with these, and put fiesh caps on to be sarten. But jest when I'd got ready, the ducks had floated down with the stream, and dropped behind the pint-so I downed on my knees, and crawled, and Dash alongside on me, for all the world as if the darned dog knowed; well, I crawled quite a piece, till I'd got under a bit of alder bush, and then $I$ seen them-all in a lump like, except two-six ducks and a big drake-feedin', and stickin' down their heads into the weeds, and flutterin' up their hinder eends, and chatterin' and jokin'-I could have covered them all with a handkercher, exceptin' two, as I said afore, one duck and the little drake, and they was off a rod or better from the rest, at the two different sides of the stream-the big bunch warn't over ten rods 
off me, nor so far; so I tuck sight right at the big drake's neck. The water was quite clear and still, and seemed to have caught all the little light as was left by the sun, for the skies had got pretty dark, I tell you; and $I$ could see his head quite clear agin the waterwell, I draw'd trigger, and the hull charge ripped into 'em-and there was a scrabblin' and a squatterin' in the water now, I tell you-but not one on 'em riz-not the fust one of the liull bunch; but up jumped both the others, and I draw'd on the drake-more by the whistlin' of his wings, than-that I seen him-but I drawed stret, Archer, any ways; and arter I'd pulled half a moment I hard him plump down into the crick with a splash, and the water sparkled up like a fountain where he fell. So then I did n't wait to load, but ran along the bauk as hard as I could strick it, and when I'd got down to the spot, I tell you, little Dash had got two on 'em out afore I came, and was in with a third. Well, sich a cuttin' and a splashin' as there was you nivir did see, none on you-I guess, for sartin-leastwise I nivir did. I'd killed, you see, the drake and two ducks, dead at the first fire, but three was only wounded, wing-tipped, and leg-broken, and I can't tell you what all. It was all of nine o'clock at night, and dark as all out doors, afore I gathered them three ducks, but I did gather 'em; Lord, boys, why I'd stayed till mornin', but I'd a got them, sarten. Well, the drake I killed flyin' I could n't find him that night, no how, for the stream swept bim 
- down, and I had n't got no guide to go by, so I let him go then, but I was up next mornin' bright and airly, and started up the stream clean from the bridge here, up through Garry's back-side, and my bog-hole, and so on along the meadows to Aunt Sally's run-and looked in every willow bush that dammed the waters back, like, and every bunch of weeds and brier-brake, all the way, and sure enough I found him, he'd been killed dead, and floated down the crick, and then the stream liad washed him up into a heap of broken sticks and briers, and when the waters fell, for there had been a little freshet, they left him there breast uppermost-and I was glad to find him-for I think, Archer, as that shot was the nicest, prettiest, etarnal, darndest, long, good shot, I iver did malre, anyhow; and it was so dark I could n't see him.".

Many of his friends and mine will recognize the character, to whom I allude, as he figures largely in the pages of "The Warwick Woodlands," from which the above extract is taken, of "My Shooting-box," and the other sporting scenes of Frank Forester, wherein nothing good or generous or kind is related of Tom Draw, that does not fall far short of the reality.

Defore closing this article, I will correct an error into which I perceive I have inadvertently fallen in the first page of it, wherein I said that this duck, alone of the family, has the habit of perching, roosting, and nesting on trees. 
I should have said alone of the American family; for I find a note by Mr. Brewer, the last editor of Wilson, annexed to his article on our bird, which I prefer to subjoin instead of merely making a verbal alteration, since I doubt not many others are in the same error, who will be glad to be corrected in detail. It appears, as. will be seen below, that, although there are no European tree-ducks, nor any other American, there is a family of Asiatic and African congeners of our Summer Duck, for which an especial name has been proposed, though not as yet generally adopted. I might add that the present Latin name of our bird, anas sponsa, signifies, being interpreted, the bride duck, from the rare elegance of its form and beauty of its plumage-a pretty name for a pretty creature.

"These lovely ducks may be sard to represent an incessorial form among the anatidoe; they build and perch on trees, and spend as much time on land as upou the waters; Dr. Richardson has given this group, containing few members, the title of dendronessa from their arboreal habits. Our present species is the only one belonging to America, where it ranges rather to the south than north; the others, I believe, are all confined to India. They are remarkable for the beauty and splendor of their plumage, its glossy, silky texture, and for the singular form of the scapulars, which, instead of an extreme development in length, receive it in the contrary proportion of breadth; and instead of lying flat, in 
some stand perpendicular to the back. They are all adorned with an ample crest, pendulous, and running down the back of the neck. They are easily domesticated, but I do not know that they have been yet of much utility in this state, being more kept on account of their beauty, and few have been introdnced except to our menageries; with a little trouble at first, they might form a much more common ornament about our artificial pieces of water. It is the only form of a Tree Duck common to this continent; in other countries there are, however, two or three others of very great importance in the natural system, whose structure and habits have yet been almost entirely. overlooked or lost sight of. These seem to range principally over India, and more sparingly in Africa; and the Summer Duck is the solitary instance, the United States the nearly extreme limit, of its own peculiarities in this division of the world."

With this note I close this paper, expressing only the hope that the bird will become more largely domesticated; as no more beautiful adornment can be conceived to the parks and shrubberies of gentlemen, such more especially as possess the advantages of small inland rivulets, or pieces of ornamental water, whether natural or artificial. 



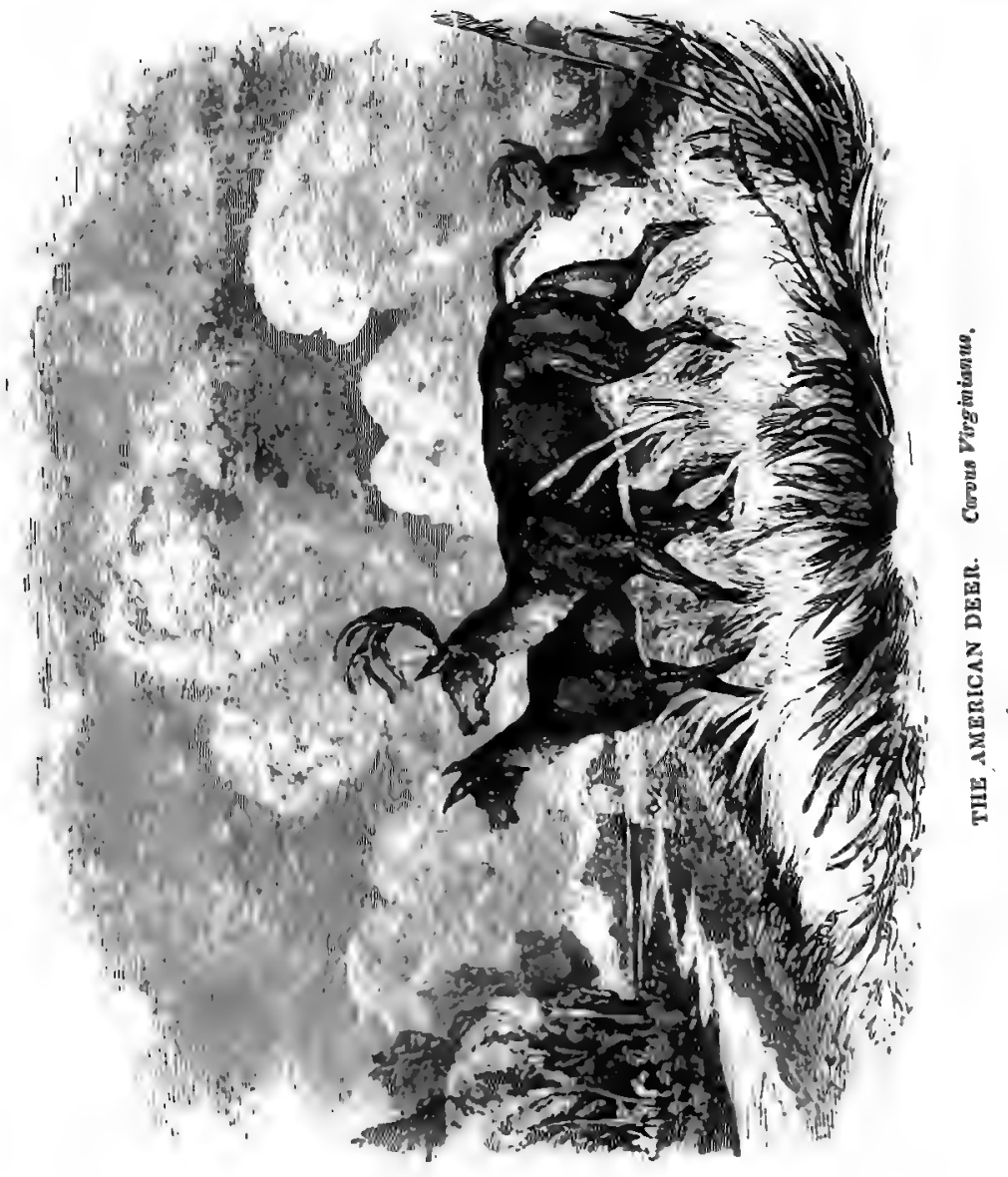




\section{THE AMERICAN DEER.}

\section{Cervus Virginianus.}

THIs beautiful and noble animal, formerly so abundant in every part of the United States, from the Great Lakes to the ocean, and from the eastern boundaries of Maine to the southern limit of their vast empire, is peculiar to the continent of America, and differs entirely from each of the three European species, with two of which it has been at times confounded, and even more markedly from all the African and Asiatic varieties.

The deer of Europe, and of Great Britain in particular, from which country we have derived most of our sporting propensities and traditions, and I might add all our sporting nomenclature, consist of three very distinct species. These are, first, the Red Deer, which is now found only in the Highlands of Scotland, with the exception of a few in Somerset and Devon, and the extreme western wilds of Ireland. The male of these is known as the Stag or Hart, and the female as the Hind. This is a magnificent and imposing creature, handsomer 
even and more stately than our deer, with branched antlers exactly similar to those of our great western Elk, though of inferior size.

Second, the Fallow Deer, the species usually kept in a semi-domesticated state in the parks of the nobility and gentry, both as an ornament to the scenery, and as an article of luxury for the table. This is a beautiful and graceful creature, far less stately than the Red Deer, or the denizen of our forests, but slightly and symmetrically moulded, and the very bean ideal of grace and airy motion. It has flattened or palmated horns, about midway in form between those of the Moose and Cariboo, or. American Reindeer, though, of course, proportionally smaller. In color, the Fallow Deer differs materially from all the other species, and is itself by no means uniform, some individuals being almost black, and others nearly white; the majority are, however, beautifully dappled, and some pied, with tints of brown fawn color and yellowish white.

The Fallow Deer is not believed to be indigenous to Great Britain, nor indeed to Europe, being, I imagine, of oriental origin; nor is it found any where in a state of nature or at large; being confined exclusively in parks or chases of more or less extensive range, often including large tracts of forest land; and it has been observed that the wilder the character of the park, and the more broken and forest-like the nature of the soil, especially when it produces heather or forn in abun- 
dance, the wilder and more gamy is the flavor of the venison.

The third variety is the Roe, a native of all the wilder and more broken forest regions of Great Britain, both north and south, though they are fow in number as compared with either of the other species. They are much smaller than the Red or Fallow Deer, of a unifor'm reddish-brown color, and are distinguished by small erect horns, with a single prong in front. Of the two last species the male is known as the buck, the female as tho doe.

The American Deer in size, color, the branched formation of its antlers, and the character of its flesh, most nearly resembles the Red Deer of Europe, but is clearly distinguished from that animal by some peculiarities in its structure and by the shape of its horns. In the European Red Deer, the direction of the main stem of the antlers is directly backward, all the branches or prongs springing from the anterior side and pointing forward, the lowest on each side, or brow antler, which is the principal defense of the animal against his natural enemies, the wolf and dog, bending forward and downward on the outer side of the brow and eye.

In the American Deer, the main stem at first inclines backward for about half its length, but then turns forward with a bold curve, and terminates in a sharp deflected point, all the prongs, which are sometimes themselves bifid, and even trifid, arising from the poste- 
rior side, and arising from it in a forward and upward direction. The only exception to this is the brow antler, a short erect spike, which arises from the inner and anterior surface of the principal stem.

In color the American Deer is genernlly of a reddishbrown, or fulvous tint, darker above, and pure white on the chin, throat, belly, and inside of the fore-legs, the upper:parts being more or less diversified with cinereous gray, or bluish hairs. These become more numerous during the summer, and in the autumn, and during the winter the whole animal assumes a grayer tint. The ears are margined with dark brown, and are white within, the upper side of the tail is of the same color with the upper parts in general, and is white below. The hoofs are jet black.

The female is smaller than the male, and hornless, but otherwise resembles him exactly; the fawns are beautifully spotted with irregular white spots on a fulvous or tawny ground. The male is generally known as tho buck, and the female as the doe; though, for my own part, I consider from their greater analogy to the European Red Deer than to any other variety, that Hart and Hind would be the more correct and sportsmanlike nomenclature. This is, however, at best but a subordinate matter, and need not be insisted on, especially until the graver and more important errors in sporting nomenclature, among the birds and fishes especially, have been corrected. 
The deer has usually but one, never more than two fawns at a birth. In the southern parts of the State of New York these are for the most part dropped in May and June, but further north, somewhat earlier in the year. During the rutting season the males are bold and extremely pugnacious among themselves, although not like the Red Deer capable of attacking men without provocation. The cry of the deer when alarmed is a quick, tremulous whistling sound, accompanied by a stamp of the foot; when mortally wounded they will at times utter a faint bleat like that of a young calf.

In its habits the American Deer is, for the most part, except in the vast prairies of the West, a wcodland haunter, as, according to Catallus, was the deer of Greece and Asia Minor, which, in his comprehensive and picturesque compound he describes as sylvicultrix, the lamuter of the woodlands, and in this respect it differs from the Red Deer of Great Britain, which prefers the difficult and craggy mountain-tops, or the far-extended downs covered with waving heather to the dark pine woods of the Scottish Highlands, or the beautiful oak coppices of Devonshire.

By law the killing of the American Deer has generally been restricted in most States to the months between August and December, both inclusive, but so rapid is the progress of annibilation going on with these beautiful animals that in some counties of New York the only months during which it is lawful to take them, are Sep$10^{*}$ 
tember, October, and November. All legislation, however, on the subject of game preservation would seem to be hopeless, so long as the whole tone and spirit of the popular mind of the masses is regulary set against their enforcement. Nothing, indeed, is more singular or more to be lamented than the strange perversion of intellect which seems to have come over the whole body of the white settlers of North America, whether of Canada, New Brunswick, the Atlantic States, or the far West, leading them to wage incessant and merciless war on every wild animal, whether of fur, fin, or feather, slaughtering them at all times; and in all places, in season and out of season; when their flesh is nutritive and delicious, when it is utterly unfit for the food of man; when their peltries or feathers are commercially valuable, when they are worthless; slanghtering them wantonly and recklessly for the mere love of slaughter, and often leaving their carcases to decay in the depths of the forest, until they are becoming all but extinct, as in a few years they unquestionably will, unless sounder views shall hereafter prevail. The willful waste and wanton annihilation of the buffalo in the West; the knocking on the head of the deer, in New York and Pennsylvania, with clubs, by snow-shoe mounted ruffians, during the deep snows of winter, when their flesh and hides are alike valueless-and that literally by tens of thousands; and the sweeping the spawning beds of the salmon with the seine, and persecuting the spent and 
worthless fish with spear and torch, till they have disappeared from their most favorite rivers in the British Provinces, are all forms of this same wanton, wicked, I had well nigh said fiendish spirit, which is really a characteristic, as I have observed, of the white settler of every part of America.

It is an absurdity to say that the spread of civilization and culture has destroyed the game, for it is a wellknown fact that game of all sorts increases in the very same ratio in which cultivation increases, if left nnmolested in their seasons of reproduction, nesting; spawning, or tending their helpless young, so long as a sufficiency of woodland is left to afford them shelter.

In Scotland, the Red Deer, which are strictly preserved, so far as the prohibition to kill them out of season goes, but neither fed, tended, nor herded, are and have been for years rapidly on the increase; and it would probably be within the mark to say that there are at this instant fifty times as many Red Deer in the small space to the northward of the Highland line, than in all the States between Maine and the Delaware. In the eastern and northern parts of Maine, they are still plentiful despite the sedulous efforts of the lumber-men to annihilate the race, and the occasional devastation of the wolves. In the northern parts of Vermont, Massachusetts, and Connecticut, a few are still to be found, though they are but as individuals compared to the vast herds which were wont to roam those green glades and wild 
mountain pastures. With the exception of a tew on Long Island, in the northern counties, and about the still wild banks of the Delaware, in New York, they are already extinct. In New Jersey, with a small wretched remnant of the once as abundant heath-hen, prairie-fowl, or pinnated grouse, a few straggling deer may still be found in that remote and little trarersed region called from its prevailing growth, the pines, lying along the Atlantic coast. Elsewhere they exist not. To the westward of Pennsylvania, and through the South, even so far as Texas and New Mexico, throngh the West to the Rocky Mountains, and northward through both the Canadas, they are still abundant, and will continue so, it may be expected, for . some years to come-in the Canadas and the Southern States especially, where the laws for their preservation are rigidly enforced, and where the greater number of educated men and gentry. settled throughout the rural districts, have produced some effect on the mind of the masses as regards the wholesale and useless extinction of game out of season.

The modes of pursuing and taking this fine animal, whether for pleasure or profit, are almost innumerable, but of these almost all partake of the poaching or pothunting system too much to obtain from me more than a mere passing notice.

The first and most generally practiced of these is what is variously called driving, or stand-hunting, in which the shooters are placed on the circuit of a certain tract 
of woodlands, each one at the debouchure of a deer-path, upon some lake, streamlet, or road which it may chance to intersect, while the interior of the circuit is beat by drivers and hounds, which force the deer firom the tract by one or other of the paths; and than this, although it has, I know, its passionate votaries, I can conceive no duller, more poacher-like, or sess exciting sport-if sport it must be called.

The standing shivering, or sweltering for hours, as it may chance to be in August or in December, at a runway, perhaps not once hearing the hounds even at a distance from morn till dewy eve; perhaps catching for a moment the volume of their cadenced cry, only to hear it die away in the distance until the crack of a remote rifie tells you that the deed is done, and that not unto you is the doing of it; perhaps, if you have the very best luck of it, hearing the cry come nigher, nigher, swelling momently on the ear, hearing the bushes shaken, and the dry sticks crackling under a rapid foot, and then to complete the whole, seeing a great, timid, trembling, helpless beast driven up to within ten feet of the muzzle of your shot-gun or rifle, which, after whistling or bleating at him to compel him to stop short in his tracks and stand motionless as a mark for your buckshot practice, you incontinently butcher in cold blood.

Yet a more scurvy mode than this, of deer-hunting, is practiced by night, under the name of fire-hunting, in two different ways, either by floating and paddling in 
canoes along the margin of streams and brooks to which the deer come down to feed, having a light elevated in the bows upon a plank which partially conceals the person of the shooter-or by walking stealthily through the woods with a fire-pan supported by a staff, and filled with blazing light wood knots, carried before you by an assistant, close in whose wake you crawl along, with ready gun, prepared for secret murder. Seeing the mysterious lights through the glimmering twilight of the woods, the timid deer stands at gaze half curious, half fascinated, until the strong reflected light falling on the balls of his distended eyes, makes them glare out like balls of fire, and enables his dastardly associate to point - the deadly tube directly at the centre of his broad fair brow between them, and so to slay him unsuspecting.

Worse yet, indeed worst of all, where all are bad and base, is the practice borrowed from the Indian, who killing not for sport but for necessity, not to gratify the hunter's gallant zeal, but to supply his wigwam with food for its inmates, at all times killed from ambush, and never discharging an arrow but when he was sure of killing-is the practice, I say, of lying in ambush by some salt-lick, or spring to which the deer comes down to drink, and, well concealed to the leeward of his path, to shoot him down without difficulty, as without excitement.

The more legitimate modes-the only modes to which $I$ think the true sportsman will resort--are deer-stalking, 
or as it is called still-hunting, in the north-hunting the Hart manfully and gallantly with fleet horses, and a cry of well-matched and tuneful fox-hounds, with the blythe view halloa, and the cheery blast of the key-bugle, with the chivalric sportsmen of the sunny south-and last, not least, coursing him with a leash of fleet greyhounds, or, better yet, a leash of the tall, wire-haired, roughcoated deer-hounds of the Scottish Highlands, orer the wild and verdant prairies of the West.

The first of these methods is the only one, which the rough, craggy, and mountainous character of the forestland frequented by deer in the Northern States, which horses cannot for the most part traverse at all, certainly not at speed, will allow the hunter to adopt; and if it lack the maddening excitement of galloping over bush, bank, and scaur, taking bold leaps, and striding irresistible over ravine or gully, over fallen tree or rough railfence, with the fierce music of the hounds stirring your brain almost to madness, it requires at least so many qualities of skill and science, such quickness of eyesight, such instinctive calculation of causes and effects, such Indian-like power of following the faintest trail, of detecting by the displacement of a yellow leaf, by the disordered foliage of a broken bash, or the broken bark on a frayed sapling, whither and when, and at what pace the object of pursuit has passed that way, that by the consciousness of, and confidence in your own self-power, self-energy, and self-sufficiency to all emergencies, that 
it must be considered as a sport, and as one of a high and noble order. To these advantages again are to beadded the wild and glorious haunts of nature into which it leads our vagrant footsteps-the springs, fitted to be the baths of brighter nymphs than any of those who trod immortal, Dryads or Oreads of Delia's train, by which we eat our frugal meal, and with which we qualify our temperate cups-the high and liberal mountain-tops, visited by a clearer and more lnstrous sunshine, fanned by a purer and more exhilarating air, than any known to the sleek citizen, to which we climb, led by the fierce excitement of pursuit; and then the ruddy watch-fire silently blazing in the depths of the mysterions wilderness before the bark-roofed shanty, before the hemlock bed, which shelter and console us after the long tramp and the hurried chase-the awakening to the cries of the early birds, in the fresh gray of the awakening dawn, the delicious bath in the clear basin of the mountaintorrent, the woodman's morning meal of trout or venison, cooked by the glowing embers, and eaten with no better condiments than appetite and exercise and health may furnish-all these-all these are the delights which add so inspiriting a charm to the North Country still-hunt, and half tempt the dwellers of pent cities to abandon the culture, the luxury, the companionship, and the civilization of gentlemen, for the more congenial toils and more inspiriting delights of the woodman's life. 
That is an aspiration which all men, who have tasted of the freshness, the originality, the primitive elastic vigor of the woodland life, untrammeled by no formulæ, fettered by no false and absurd conventionalities, a life emphatically of men, desire to taste again-yearn after it, how eagerly, when debarred from it by the hateful necessities of business-and, when they return to it, after years of desuetude, greet it as old men would greet renewed manhood, or exiles restored home. This is the feeling which is so instinct of life, and sunshine, and breezy freshness in the writings of the earlier and more original of England's poets-which prompted one great Roman to cry mournfully, "O rus, O rus, quendo ego te aspiciam," and another to admit half apologetically, as if it were in some sort a reproach, "Flumina amen et sylvas mutosque inglorius amnes;" and in all breasts a something of this hunter's spirit, under one form or other will burst perennial, until we go whither the weary are atrest, and the wicked cease from troubling. And a good spirit it is, in moderation, and good to be indulged-and so up with the forest chaunt.

So it is-yet let us sing

Honor to the old bowstring !

Honor to the bugle horn!

Honor to the woods unshorn!

Honor to the Lincoln green !

Honor to the wocdman keen! 
and health, and joy, and success still increasing to the bold, the fair, the gallant hunter, as all ill-fortunes and most foul reverses to the disloyal pot-hunter, the low and sordid poacher of whatever land he be ! 


\section{IX.}

\section{SEPTEMBER.}

\section{The Garent-aldingè Tead. \\ Anas Cardinensis.}

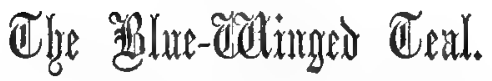 Anas Discors.}

CANADA; BRITISH PROVINCES; UNITED STATES. 




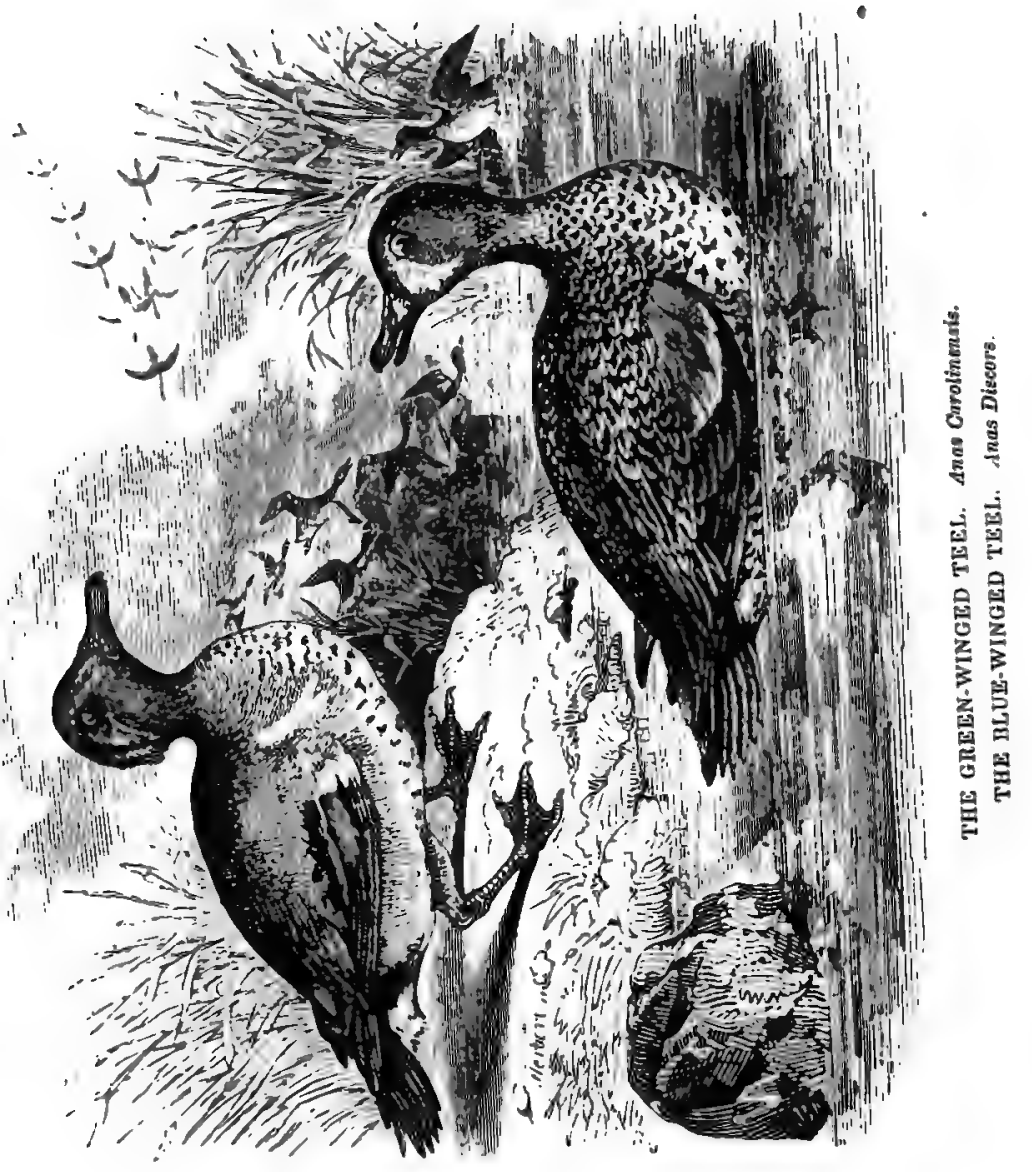




\section{THE GREEN-WINGED TEAL.}

Anas Carolinensis.

\section{THE BLUE-WINGED TEAL. Anas Discors.}

In this present month, the sport of duck-shooting on the inland strearns, rivers, and lakelets, may be held to commence in earnest, as contrasted to the pursuit of the same tribes on the outer bays, estuaries, and surf-banks. 'About the end of September, and thenceforth through this and the next ensuing month, according to the variations of the'seasons, and the longer or shorter endurance of that delicious time, the most delicious and most gorgeous of the whole American year, known throughout this continent as Indian Summer, the Mallard, and the two beautiful species which we have placed at the head of this article, begin to make their appearance on the little lakes of the interior, and in the various streams and rivers which fall into them, and thenee downward to the Atlantic seaboard.

In the vast northern solitudes of the great lakes of the northwest, in all the streams of Upper Canada, even to 
the feeders of Lake Superior, and throughout the western country so far south as Texas, and northward to the Columbia and the fur countries, the Blue-Winged Teal breeds, literally by myriads. Throughout the great lakes, it is abundant in the early autumn, becoming excessively fat on the seed of the wild rice, with which the shallows of all these waters are overgrown, and being deservedly esteemed as one of the best, if not the very best, of the duck tribe. But it is the first of its race to remove from the wild, limpid waters, and wood-embosomed rivers of the great west, to the seaboard tide-waters, taking the inland water-courses on their route, rarely visiting the actual sea-shores, and proceeding on the occurrence of the first frosts, for they are singularly susceptible of cold, to the Southern States, where they swarm, especially in the inundated rice-fields of Georgia and South Carolina, during the winter months.

The Green-Winged Teal, which is the nearest congener, and frequently the associate of the Blue-Wing, has a far less extensive range, so far as regards its breeding-grounds, in as much as it never, so far as has been satisfactorily shown, has nidificated or produced its young south of the great lakes, nor even there in great numbers, its favorite haunts for the purposes of reproduction, being the extreme northern swamps and wooded morasses, almost up to the verge of the arctic circles. It does not come down on its southward migration, at nearly so early a period of the autumn as its congener, 
being less susceptible of cold, and tarrying on the Great Lakes till the frosts set in with sufficient severity to prevent its frequenting its favorite haunts with pleasure, or obtaining its food with facility. It is rarely or never seen in the Middle States during the summer, but is tolerably abundant during the autumn on all the marshy lakes and pools, and along the shores of all the reedy rivers from the Great Lakes downward to the sea-board, though, like the last named species, it is purely a freshwater duck, never frequenting the sea-shores or salt-bays, finding no food thereon with which to gratify its delicate and fastidious palate, which, eschewing fish, the larvæ of insects, and the lesser crustacos, relishes only the seeds of the various water plants and grasses, the tender leaves of some vegetables, and more especially the grain of the wild rice, Zizania panioula effusa, which is its favorite article of subsistence, and one to which may be ascribed the excellence of every bird of air or water which feeds on it, from the Rice-Bird and the Rail, to the Teal, the Canvass-Back, and even the large ThickBilled Fuliguta, closely allied to the Scoter, the Velret Duck, and other uneatable sea-fowl of Lake Huron, which are scarcely, if at all, inferior to the Red-Heads of Chesapeake Bay, the Gunpowder, or the Potomac. On the Susquehanna and the Delaware, both these beautiful little ducks were in past years excessively abundant, so that a good gunner, paddling one of the sharp, swift skiffs peculiar to those waters, was certain 
of tilling his boat with these delicious ducks within a few hours' shooting. Both of these species are rather tame than otherwise, the blue-winged bird more particularly which has a habit, on the lower waters of the Delaware especially, of congregating on the mud in vast flocks, sunning themselves in the serene and golden light of a September noon, so careless and easy of approach, that the gunner is frequently enabled to paddle his skiff within a few yards of them, and to rake them with close discharges of his heavy batteries. At times, when the tide is out, and the birds are assembled on the flats out of gunshot from the water's edge, the thorough-going sportsman, reckless of wet feet or muddy breeches, will run his skiff ashore, several hundred yards above or below the flock, and getting cautiously overboard, will push it before him over the smooth, slippery mud-flats, keeping himself carefully concealed under its stern until within gunshot, which he can sometimes reduce to so little as fifteen or twenty yards, by this murderous and stealthy method. The Green-Winged Teal is much less apt to congregate, especially on shore, than the other, and consequently affords less sport to the boat-shooter, keeping for the most part afloat in little companies, or trips, as they are technically called, very much on the alert, and springing rapidly on the wing when disturbed. They, and the Blue-Wings also, fly very rapidly, dodging occasionally on the wing, not unlike to a wild, sharpflying Woodcock, and when they alight, darting down- 
ward with a short, sudden twist among the reeds or rushy covert, exactly after the fashion of the same bird.

The commoner and, in our opinion-where these birds are abundant either along the courses of winding drains or streamlets, or in large reedy marshes, with wet soil and occasional pools or splashes-far the more exciting way of killing them is to go carefully and warily on foot, with a good medium-sized double-gun, say of eight to ten pounds weight, and a thoroughly well broke and steady spaniel, to retrieve and occasionally to flush the birds, which will sometimes, though rarely, lie very hard. A good sportsman will frequently, thus late in the autumn, when the mornings are sharp and biting, and the noons warm and hazy, but before the ice makes, pick up, on favorable ground, his eight or nine couple in a day's walking, with a chance of picking up at the same time a few Snipe, Golden Plovers, Curlew, or Godwit; and this, in our mind, is equal to slaughtering a boat load by sneaking up in ambush to within twenty yards of a great company, whistling to make them lift their heads and ruffle up their loosened plumage, so as to give easy entrance to the shot, and then pouring into them at half point-blank range, a half pound of heavy shot.

"In the southern States they are commonly taken," says Wilson, in "vast numbers, in traps placed on the small dry eminences that here and there rise above the water of the inundated rice-fields. These places are strewed with rice, and by the common contrivance 
called a tigure four, they are caught alive in hollow traps." This we, of course, merely mention as illustrative of the habits of the bird; for, of course, no sportsman would dream of resorting to so worse than poacherlike proceeding. The mode described by the eloquent. pioneer of American natural history, is probably practised, for the most part, by the negroes for the supply of their masters' table, and furnishing their own pockets with a little extra change, and is not used by the planters as a means of sport or amusement. It must be remembered, a!so, that Wilson, than whom there is no writer more to be relied on in matters which he relates of his own knowledge, and as occurring in his own days, must often be taken cum grano salis, as to the numbers of birds slain in this way or that within a certain timethings which he records, probably, on hearsay, and on which-we are sorry to say it-even good sportsmen, men who on any other subject would scorn to deviate one hair's breadth from the truth, will not hesitate to draw a bow as long and as strong as Munchausen's. Again, he writes of times when sporting was but little pursued, otherwise than as a method of procuring superior food for the table, or for the purpose of destroying noxious vermin and beasts of prey; when the rules of sportsmanship were little understood and as little regarded; and, lastly, when game abounded to a degree literally inconceivable in our day-although we have ourselves seen, with sorrow, the diminution, amounting 
in many regions around our large cities almost to extinction, of all birds and beasts-nay, but even fish of chase, within the last twenty years. We must be careful therefore not to charge exaggeration on a writer who beyond a doubt, faithfully recorded that which he himself saw and enjoyed in his day; which we might see likewise and enjoy in our generation, and our children and grand-children after us, if it were not for the greedy, stupid, selfish, and brutal pot-hunting propensities of our population, alike rural of the country and mechanical of the cities, which seems resolutely and of set purpose bent on the utter annibilation of every species of game, whether of fur, fin, or feather, which is yet found within our boundaries.

In my opinion, the common error of all American fowlers and dnck shooters, lies, in the first place, in the overloading the gun altogether, causing it to recoil so much as to be exceedingly disagreeable and even painful and in the same degree diminishing the effect of the discharge; for it must never be forgotten that when a gun recoils, whatever force is expended on the retrogressive motion of the breech, that same force is to be deducted from the propulsion of the charge. In the second place, he erroneously loads with extremely large and heavy shot, the result of which is, in two respects, inferior to that of a lighter and higher number. First, as there will be three or four pellets of No. 4 for every one pellet of $\mathrm{A}$ or $\mathrm{B}$ in a charge, and, consequently, as 
the load is thereby so much the more regularly distributed, and so much the more likely to strike the object, and that in several places more, in the ratio of three or four to one, than could be effected by A's or B's. Second, as the flesh will constantly close over the wound made by a small shot, so as to cause the bleeding to go on internally to the engorgement of the tissues and suffocation by hemorrhage; whereas the wound made by the large grain will relieve itself by copious bleeding, and the bird so injured will oftentimes recover, after having fallen even to the surface of the water, or lain flapping, as it were, in the death-struggle on the bloodstained sand or grassy hassocks. This fact has been well noticed, and several examples adduced to prove its truth, by Mr. Giraud, in his exceedingly clear and correct, though to our taste, far too brief volume on the "Birds of Long Island."

For my own use I invariably adopt for all the smaller species of duck-as the two varieties of Teal, the Summer Duck, the Golden Eye, and the Buffel-headed Duck, Anates, Carolinensis, Discors, Sponsa, and Fuligulos, Clangula, and Albeola-the same shot which is generally used for the various birds known on our shores and rivers as bay-snipe, viz: No. 4 or 5 -the latter best for the Plovers, the former for duck, whether in large or small guns. In this relation I may observe that, on one occasion-the only one, by the way, on which I ever saw a green-winged teal in the summer season-I killed 
a couple of these beautiful birds, right and left, while woodcock shooting, in Orange County, New York, with No. 8 shot. They sprang quite unexpectedly from behind a willow bush, on the Wawayanda creek, and I dropped them both quite dead, somewhat to my own astonishment, and to the utter astounding of Fat Tom, who witnessed it, into the middle of the stream, respectively of twenty and twenty-five yards distance. Until I recovard them I supposed that they were young wood ducks, but on examination they proved to be young greenwinged teal, of that season, in their immature plumage. This must have been in the last week of July or the first of August-it was many years since, and as at that time I kept no shooting diary, I unfortunately am unable to verify the exact date. The birds must, I conclude, have been bred in that vicinity, by what means I cannot conjecture, unless that the parent birds might have been wounded in the spring, and disabled from completing their northern migration, and that this, as is sometimes the case with the minor birds of passage, might have superinduced their breeding in that, for them, far southern region. In corroboration of this I may add that, in the spring of 1846, a couple of these birds haunted a small reedy island in fiont of my house, on the Passaic, to so late a day in summer-the $29 \mathrm{th}$, if I do not err, of May--that I sedulously avoided disturbing them, in the hope that they would breed there. This I yet think would have been the case but for the constant disturb- 
ance of that lovely river throughout the summer by gangs of ruffianly loafers, with whom the neighboring town of Newark abounds beyond any other town of its size in the known world, boating upon its silvery surface day and night, and rendering day and night equally hideous with their howls and blasphemies.

Before proceeding to the description of these birds it is well to observe that it will be found the better way, in approaching them, as indeed all wild fowl, to work, if possible, up wind to them; not that wild fowl have the power, as some pretend, of scenting the odor of the human enemy on the tainted gale, as is undoubtedly the case with deer and many other quadrupeds, but that their hearing is exceedingly acute, and that their heads are pricked up to listen, at the occurrence of the least unusual sound, and at the next moment-hey, presto!they are off.

The little cut at the head of this paper, for the spirited and faithful execution of which the author and artist must be permitted to return his acknowledgments to his friend, Mr. Brightly, represents a favorite feeding-ground of the various tribes of water fowl, as is indicated by the large gaggle of geese passing over, from right to left, and the trip of green-wings alighting to the call of a. clamorous drake in the background. On a rocky spur of the shore, in the right foreground, is a male GreenWinged Teal, in the act of springing, with his legs already gathered under him; and, still nearer to the front 
of the picture, on the right, a Blue-Winged Drake, swimming on the limpid water, soliciting his congener, with reverted neck, and the harsh gabble-whence his name-to take wing and greet the new-comers-it being the object of the draftsman to give an idea not merely of the markings and form of these two most beautiful and graceful of the duck tribe, but of their motions, the character of their flights, and the nature of their feedinggrounds and habitations.

The head of the Green-Winged Teal is of moderate size and compressed; the bill nearly as long as the head, deeper than broad at the base, depressod at the tip; neck slender, of moderate length; body full and depressed; wings rather small, feet short and rather far back.

The plumage is short and blended; that of the hinder head and neck elongated into a soft filamentous drooping crest. The bill is black; iris hazel; feet light blue; head and upper part of neck bright chestnut brown; a broad band of shining rich bottle-green, narrowing from the eye backward and downward to the nape, margined below with black, anterior to which is a white line; chin dusky brown. Upper parts and flanks white, beautifully and closely undulated with narrow lines of cleep gray. Anterior to the wings is a broad transverse lunated white bar-this alone distinguishing the American from the European bird. The wing coverts, scapulars and quills gray. The speculum bright green above, 
blue-black below, margined posteriorly with pure white. Tail brownish gray, margined with paler brown. Lower part of the neck undulated, like the back. Breast pale rufous, spotted and banded with black; white below. Abdomen white, barred with gray. A black patch under the tail ; the lateral tail coverts tawny, the larger black, white-tipped and margined. Length of male

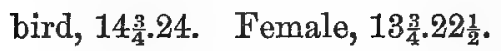

The description and drawing of this bird are taken, by kind permission, which the writer gratefully acknowledges, from a fine specimen in the Academy of Natural Science of this city.

The Blue-Winged Teal is rather larger than the above, the male measuring $16.31 \frac{1}{2}$, the female 15.24.

The shape and proportions of this bird closely resemble those of the latter, but in plumage it widely differs from it. The bill is blueish black; iris dark hazel ; feet dull yellow, webs dusky; upper part of the head black, a semilunar patch of pure white, margined with black anterior to the eye; the rest of the head and upper neck deep purplish gray, with changeable ruddy reflections. The lower hind neck, back, alula, and upper parts generally, rich chocolate brown, every feather margined with paler tints, from reddish buff to pale reddish gray, with black central markings, changing to metallic green in the centres. Upper wing coverts rich ultra-marine blue, with a metallic lustre; the lower parts pale reddish orange, shaded on the breast with purplish red, and 
thickly spotted with roundish or elliptical black spots; axillary feathers, lower wing coverts, and a patch on the side of the rump, pure white; lower tail coverts brownish black.

These, with the exception of the Buffel-Headed Duck, are the two smallest; with the exception of the Summer Duck, the two loveliest; with the exception of the Canvas-Back the two best of the duck tribe. Well met be they, whether on the board or in the field-shot be they with No. 4 eaten roast, underdone, with cayenne and a squeeze of a lemon, lubricated with red wine, quantum suff. 



\title{
$\mathrm{X}$.
}

\section{OCTOBER.}

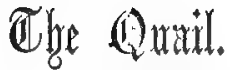 \\ Ortyo Virginianus.
}

\section{THE AMERICAN PARTRIDGE.}

CANADA WEST; MASSACHUSETTS TO MEXICO.

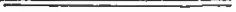 \\ The 蒴ittern. \\ Ardea Lentiginosa. \\ THE QUAWK. THE DUNKADOO.
}

CANADA; BRITISH PROVINCES; UNITED STATES, 




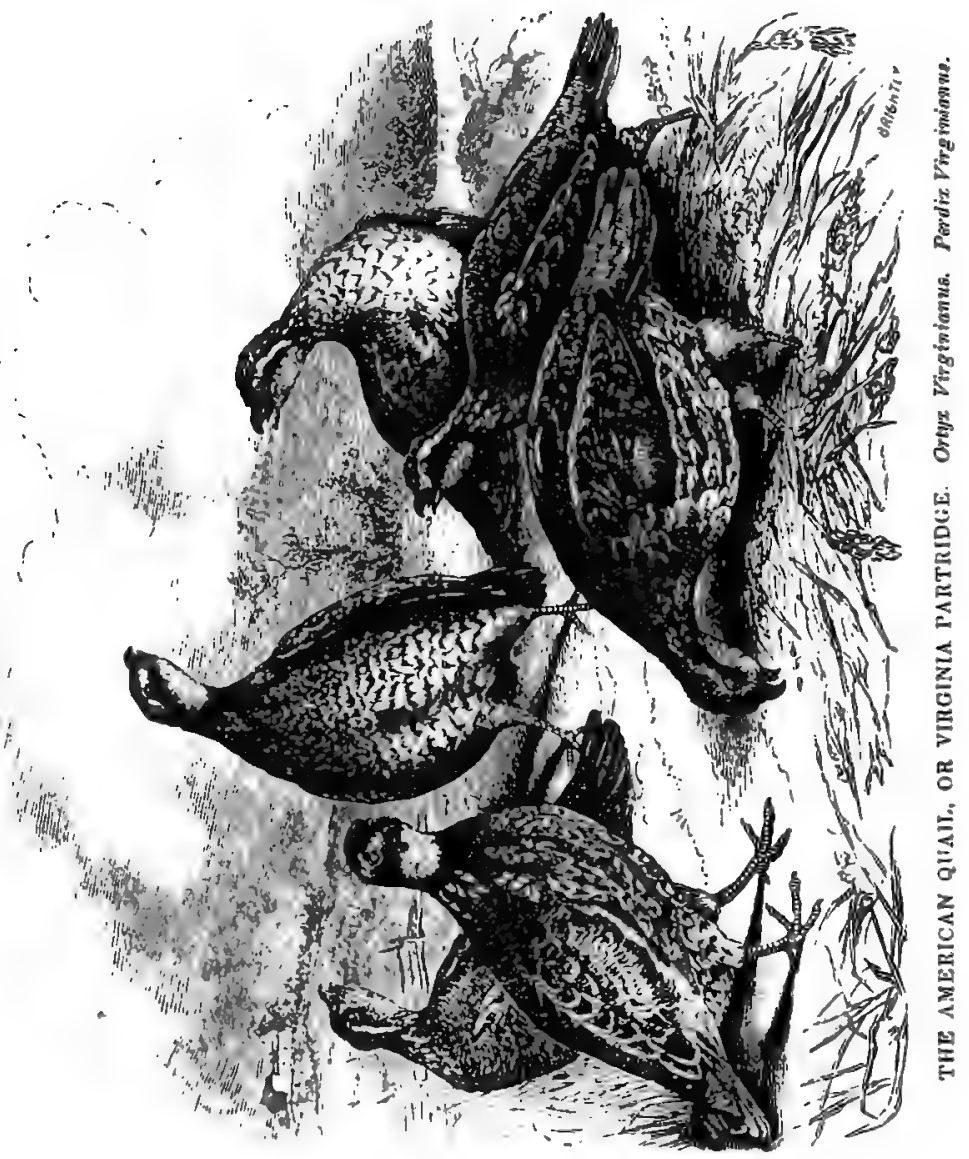




\section{THE AMERICAN QUAIL, OR VIRGINIA PARTRIDGE.}

Ortyx Virginianus. Perdix Virginianus.

Noverreer is upon us-hearty, brown, healthful November, harbinger of his best joys to the ardent sportsman, and best beloved to him of all the months of the great annual cycle; November, with its clear, bracing, western breezes; its sun, less burning, but how far more beautiful than that of fierce July, as tempered now and softened by the rich, golden haze of Indian summer, quenching his torrent rays in its mellow, liquid lustre, and robing the distant hills with wreaths of purple light, half mist, half shrouded sunshine; November, with its wheat and buckwheat stubbles, golden or bloody red; with its sere maize leaves rustling in the breeze, whence the quail pipes incessant; with its gay woodlands flaunting in their many-colored garb of glory; with its waters more clearly calm, more brilliantly transparent than those of any other season; November, when the farmer's toils have rendered their reward, and his reaped harvests glut his teeming garners, so that he too, like the pent 
denizen of swarming cities, may take his leisure with his guin "in the wide vale, or by the deep wood-side," and enjoy the rapture of those sylvan sports which he may not participate in sweltering July, in which they are alas! permitted by ill-considered legislation, in every other state, save thine, honest and honorable Massachusetts.*

In truth there is no period of the whole year so well adapted, both by the seasonable climate, and the state of the country, shorn of its crops, and not now to be injured by the sportsman's steady stride, or the gallop of his high-bred setters, both by the abundance of game in the cleared stubbles and the sere woodlands, and by the aptitude of the brisk, bracing weather, for the endurance 'of fatigue, and the enjoyment of manful exercise, as this our favorite November.

In this month, the beautiful Ruffed Grouse, that mountain-loving and man-shunning hermit, steals down from his wild haunts among the giant rhododendrons,

* A law was passed, during the spring of the present year, in that respectable and truly conservative State, by which the murder of unfledged July Woodcock, by cockney gunners, was prohibited; and the close time judiciously prolonged until September. The debate was remarkable for two things, the original genius with which the Hon. Member for Westboro' persisted that Snipe are Woodcock, and Woodcock Snipe, all naturalists to the contrary notwithstanding; and the pertinent reply to the complaint of a city member, that to abolish July shooting would rob the city sportsman of his sport-viz., that in that case it would give it to the farmer. Marry, say we, amen, so be it ! 
and erergreen rock-calmias, to nearer woodskirts, and cedar-brakes margining the red buckwheat stubbles, to be found there by the staunch dogs, and brought to bag . by the quick death-shot, "at morn and dewy eve," without the toil and torture, often most vain and rapid, of scaling miles on miles of mountain-ledges, struggling through thickets of impenetrable verdure among the close-set stems of hemlock, pine, or juniper, only to hear the startled rush of an unseen pinion, and to pause, breathless, panting, and outdone, to curse, while you gather breath for a renewed effort, the bird which haunts such covert, and the covert which gives shelter to such birds.

In this month, if no untimely frost, or envious snow flurry come, premature, to chase him to the sunny swamps of Carolina and the rice-fields of Georgia, the plump, white-fronted, pink-legged autumn Woodcock, flaps up from the alder-brake with his shrill whistle, and sóars away, away, on a swift and powerful wing above the russet tree-tops, to be arrested only by the instinctive eye and rapid finger of the genuine sportsman; and no longer as in faint July to be bullied and bungled to death by every German city pot-hunter, or every pottering rustic school-boy, equipped and primed for murder, on his Saturday's half holyday.

In this month, the brown-jacketed American hare, which our folk will persist in calling Rabbit_though it neither lives in warrens, nor burrows habitually under 
ground, and though it breeds not every month in the year, which are the true distinctive characteristics of the Rabbit-is in his prime of conditions, the leverets of the season, plump and well-grown; and the old bucks and does, recruited after the breeding season, in high health and strength, and now legitimate food for gunpowder, legitimate quarry for the chase of the merry beagles.

In this month especially, the Quail, the best-loved and choicest object of the true sportsman's ambition; the bird which alone affords more brilliant and exciting sport than all the rest beside; the bravest on the wing; and the best on the board; the swiftest and strongest flyer of any feathered game ; the most baffling to find, the most troublesome to follow up, and when followed up and found, the most difficult to kill in style; the beautiful American Quail is in his highest force and feather; and in this month, according to the laws of all the States, even the most rigorous and stringent in preservation, killable legitimately under statute.

In New York, generally, the close-time for the Quail ends with October, and he may not be slain until the first day of November; in New Jersey, ortygicide commences on the 25th of October, in Massachusetts and Connecticut on some day between the 15th of the past and the first of the present month; in Pennsylvania, Delaware and Maryland, where they are something more forward, as breeding earlier in the season than in the Eastern States, on the first of October; and in 
Canada West, where they are exceedingly abundant, on the first of September; which is, for many reasons, entirely too early, as hereafter I shall endeavor to demonstrate.

In my own opinion, the first of November, and even the middle of October, are too late for the termination of the Quail's close-time, inasmuch as five-seventlis of the broods in ordinarily forward seasons are full-grown and strong on the wing, as well as all the crops off the ground, by the first of October; and although the late, second, or third broods may be undersized, they are still well able to take care of themselves in case the parent birds are killed; whereas, on account of their immature size, they are safe from the legitimate shot; and, on account of their unsaleability in market to the restaurant, from the poaching pot-shot also.

I should, therefore, myself, be strongly inclined to advocate the adoption of one common day, and that day the first of October, for the close-time of all our upland game; the English Snipe alone excepted. Touching the reasons for postponing the day of Woodcock-shooting, a notice will be found in our July number, and an extended discussion in my Field Sports, vol. I. pp. 169 to 200. Of the Quail, in regard to this point, I have said enough here, unless this ; that, in my opinion, there is far more need to protect them from the trap during the wintry snows, than from the gun in the early autumn; the latter cannot possibly at any time exterminate the race; 
the former not only easily may, but actually does all but annililate the breed, whenever the snow falls and lies deep during any weeks of December, during the whole of which month the pursuit and sale of this charming . little bird is legal.

Could I have my way, the close-time for Quail should end on the last day of September; and the shooting season end on the twenty-fourth day of December; before which date snow now rarely lies continuously in New Jersey, Southern New York, or Pennsylvania. Why I would anticipate the termination of the closetime, in reference to the Ruffled Grouse, I shall state at length, when I come to treat of that noble bird, in our December issue; to which month I have attributed it, because it is then that it is, though in my opinion, it ought not to be, most frequently seen on our tables. While on the topic of preservation, I will mention a fact, which certainly is not widely, much less generally known, among farmers; namely, that this merry and domestic little bird is one of his best friends and assistants in the cultivation of his lands. During nine or ten months of the year he subsists entirely on the seeds of many of the most troublesome and noxious weeds and grasses, which infest the fields, more especially those of the ragwort, the dock, and the briar. It is believed, I might almost say ascertained, thiat he never plucks any kind of grain, even his own loved buckwheat when ripe, from the stalk, but only gleans the fallen seeds from the 
stubbles after harvest, so that while he in nothing deteriorates the harvest to be ingathered, he tends in the highest degree to the preservation of clean and unweeded fields and farms; indeed, when it is taken into consideration that each individual Quail consumes daily nearly two gills of weed-seed, it will be at once evident that a few bevies of these little birds, carefully and assiduously preserved on a farm, will do more towards keeping it free of weeds, than the daily annual labor of a dozen farm servants. This preservation will not be counteracted or injured by a moderate and judicious use of the gun in the autumnal months; for the bevies need thinning, especially of the cock-birds, which invariably outnumber the hens, and which, if unable to pair, from a want of mates, form into little squads or companies of males, which remain barren, and become the deadly enemies of the young cocks of the following year, beating them off and dispersing them; though, strange to say, they will themselves never mate again, nor do aught after remaining unpaired during one season, to propagate their species. The use of the trap, on the contrary, destroying whole bevies at a swoop, where the gun, even in the most skillful hands, rarely much more than decimates them, may, in a single winter's day, if many traps be set, destroy the whole stocking of a large farm for years, if not forever. I have myself invariably remarked, since my attention was first called to the fact, that those farms which are best stocked with Quail, are inva- 
riably the cleanest of weeds; and a right good sportsman, and good friend of mine, working on the same base per contra, says that, in driving his shooting-cart and dogs through a country, he has never found it worth his while to stop and beat a district full of weedy and dirty farms, as such never contain Quail.

If this may lead our farmers to consider that every live Quail does far more good on the farm, than the shilling earned by his capture in the omnivorous trap; and therefore to prohibit their sons and farm-boys from exterminating them at their utmost need, when food is scarce, and shelter hard to find, my words will not have been altogether wasted, nor my object unattained.

Were I a farmer, I would hang it over my kitchen fire-place, inscribed in goodly capitals-"Spare the Quail! If you would have clean fields and goodly crops, spare the Quail! So shall you spare your labor."

And now, in a few words, we will on to their nomenclature, their distinctive marks, their regions of inhabitation, seasons, haunts and habits; and last, not least, how, when, and where lawfully, honorably, sportsmanly, and gnostically, you may and shall kill them.

I will not, however, here pause long to discuss the point, whether they ought to be termed Quail or Partridge. Scientifically and practically they are neither, but a connecting link between the two subgenera. True Partridge, nor true Quail, very perdix, nor very coturnix, exists at all anywhere in America. Our bird, an inter- 
mediate bird betwcen the two, named by the naturalists Ortyx, which is the Greek term for true Quail, is peculiar to America, of which but one species, that before us, is found in the United States, except on the Pacific coast and in California, where there are many other beautiful varieties. Our bird is known everywhere East, and everywhere Northwest of Pennsylvania, and in Canada, as the Quail-everywhere South as the Partridge. In size, plumage, flight, habits, and cry, it more closely resembles the European Quail ; in some structural points, especially the shape and solidity of the bill, the European Partridge. On the whole, I deem it properly termed AMERICAN QUAII; but whether of the two it shall "be called, matters little, as no other bird on" this continent can clash with it, so long as we avoid the ridicule of calling one bird by two different terms, on the opposite sides of one river-the Delaware. The stupid blunder of calling the Ruffled Grouse, Pheasant, and Partridge, in the South and East, is a totally different kind of misnomer; as that bird bears no resemblance, however distant, to either of the two species, and has a very good English name of his own, videlicet, "Ruffed or Tippeted Grouse," by which alone he is known to men of brains or of sportsmanship. With regard to our Quail, it is different, as he has no distinctive English name of his own; but is, even by naturalists, indiscriminately known as Quail and Partridge. The former is certainly the truer appellation, as he approximates more 
closely to that sub-genus. We wish much that this question could be settled; which we fear, now, that it never can be, from the want of -any sporting authority; in the country, to pass judgment. The "Spirit of the Times," though still as well supported and as racy as ever, has, I regret to say, ceased to be an authority, and has become a mere arena wherein for every scribbler to discuss and support his own undigested and crude notions without consideration or examination; and wherein those who know the least, invariably fancying themselves to know the most, vituperate with all the spite of partisan personality, every person who having learned more by reading, examination of authorities, and experience than they, ventures to express an opinion differing from their old-time prejudices, and the established misnomers of provincial or sectional vulgarism.

But to resume, the American Quail, or "Partridge of the South," is too well known throughout the whole of America, from the waters of the Kennebec on the East, and the Great Lakes on the North-beyond which latter except on the South-western peninsula of Canada West, lying between Lakes Erie, St. Clair, and Huron, they are scarcely to be found-is too well known, almost to the extreme South, to need description. Their beauty, their familiar cry, their domestic habits during the winter, when they become half-civilized, feeding in the barnyards, and often roosting under the cattle-sheds with the 
poultry, render them familiar to all men, women, boys and fools throughout the regions which they inhabit. It is stated by ornithologists, that they abound from Nova Scotia and the northern parts of Canada to Florida and the Great Osage villages; but this is incorrect, as they rarely are seen eastward of Massachusetts ; never in Nova Scotia, or Canada East; and range so far as Texas and the edges of the great American salt desert. The adult male bird differs from the hen in having its chaps and a remarkable gorget on the throat and lower neck, pure white, bordered with jetty black; which parts in the young male and the adult female, are bright reddishyellow; the upper parts of both are beautifully dashed and freckled with chestnut and mahogany-brown, black, yellow, gray, and pure white; the under parts pure white, longitudinally dashed with brownish red, and transversely streaked with black arrow-headed marks. The colors of the male are all brighter, and nore definite, than in the female.

Everywhere eastward of the Delaware the Quail is resident, never rambling far from the haunts in which he is bred. Everywhere to the westward he is in the later autumn migratory, moving constantly on foot, and never flying. except when flushed or compelled to cross streams and water-courses, from the west eastward; the farther west, the more marked is this peculiarity.

The Quail pairs early in March; begins to lay early in May, in a nest made on the surface of the ground, 
usually at the bottom of a tussock or tuft of grass, her eggs being pure white, and from ten to thirty-two in number, though about fourteen is probably the average of the bevies. The period of incubation is about four weeks, the young birds run the instant they clip the shell, and fly readily before they have been hatched a fortnight. So soon as the first brood is well on the wing, the cock takes charge of it, and the hen proceeds to lay and hatch a second, the male bird and first brood remaining in the close vicinity, and the parents, I doubt not, attending the labor of incubation and attending the young. This I have long suspected; but I saw so many proofs of it, in company of my friend and fellow sportsman, "Dinks," while shooting together near Fort Malden, in Canada West-where we found, in many instances, two distinct bevies of different sizes with a single pair of old birds, when shooting early in September of last year-that we were equally convinced of the truth of the fact, and of the unfitness of the season.

In October, with the exception of a very few late broods, they are fit for the gun; and then, while the stubbles are long, and the weeds and grasses rank, they lie the best and are the least wild on the wing. The early mornings and late afternoons are the fittest times for finding them, when they are on the run, and feeding in the edges of wheat and rye stubbles, or buckwheat patches bordering on woodlands. In the middle of the day they either lie up in little brakes and bog-meadows, 
or bask on sandy banks, and craggy hill-sides, when they are collected into little huddles, and are then diffcult to find. $\Delta \mathrm{s}$ soon as flushed, they pitch into, the thickest neighboring covert, whether bog-meadow, briarpatch, cedar-brake, ravine, or rongh corn-stubble, they can find, their flight being wild, rapid, and impetuous, but rarely very long, or well sustained. As they unquestionably possess the mysterious power, whether voluntary or involuntary, of holding in their scent, for a short time after alighting, and are difficultly found again till they have run, I recommend it, as by far the better way, to mark them down well, and beat for another bevy, until you hear them calling to each other; then lose no time in flushing them again, when they are sure to disperse, and you to have sport with them.

Myself, I prefer setters for their pursuit, as more dashing, more enduring, and abler to face briars-others prefer pointers, as steadier on less work, and better able to fag without water. Either, well broke, are good--ill broke, or unbroke, worthless. Still give me settersRussian or Irish specially! Quail fly very fast, and strong, especially in covert, and require the whole charge to kill them dead and clean. At cross shots, shoot well ahead; at rising shots, well above; and at straight-away shots, a trifle below your birds; and an oz. $\frac{1}{2}$ of No. 8 early, and of No. 7, late, will fetch them in good style. And so good sport to you, kind reader ; for this, if I err not, is doomed to be a crack Quail season. 


\section{THE BITTERN. AMERICAN BITTERN.}

Ardea Minor sive Lentiginos.

\section{THE INDIAN HEN. THE QUAWK. THE DUNKADOO.}

THrs, though a very common and extremely beautiful bird, with an exceedingly extensive geographic range, is the object of a very general and perfectly inexplicable prejudice and dislike, common, it would seem, to all classes. The gunner never spares it, although it is perfectly inoffensive; and-although the absurd prejndice, to , which I have alluded, causes him to cast it aside, when killed, as uneatable carrion, its flesh is in reality very delicate and juicy, and still held in high repute in Europe; while here one is regarded very much in the light of a caninibal, as I have myself experienced, for venturing to eat it. The farmer and the boatman stigmatize it by a filthy and indecent name. The cook turns up her nose at it, and throws it to the cat; for the dog, wiser than his master, declines it-not as unfit to eat, but as game, and therefore meat for his masters. 


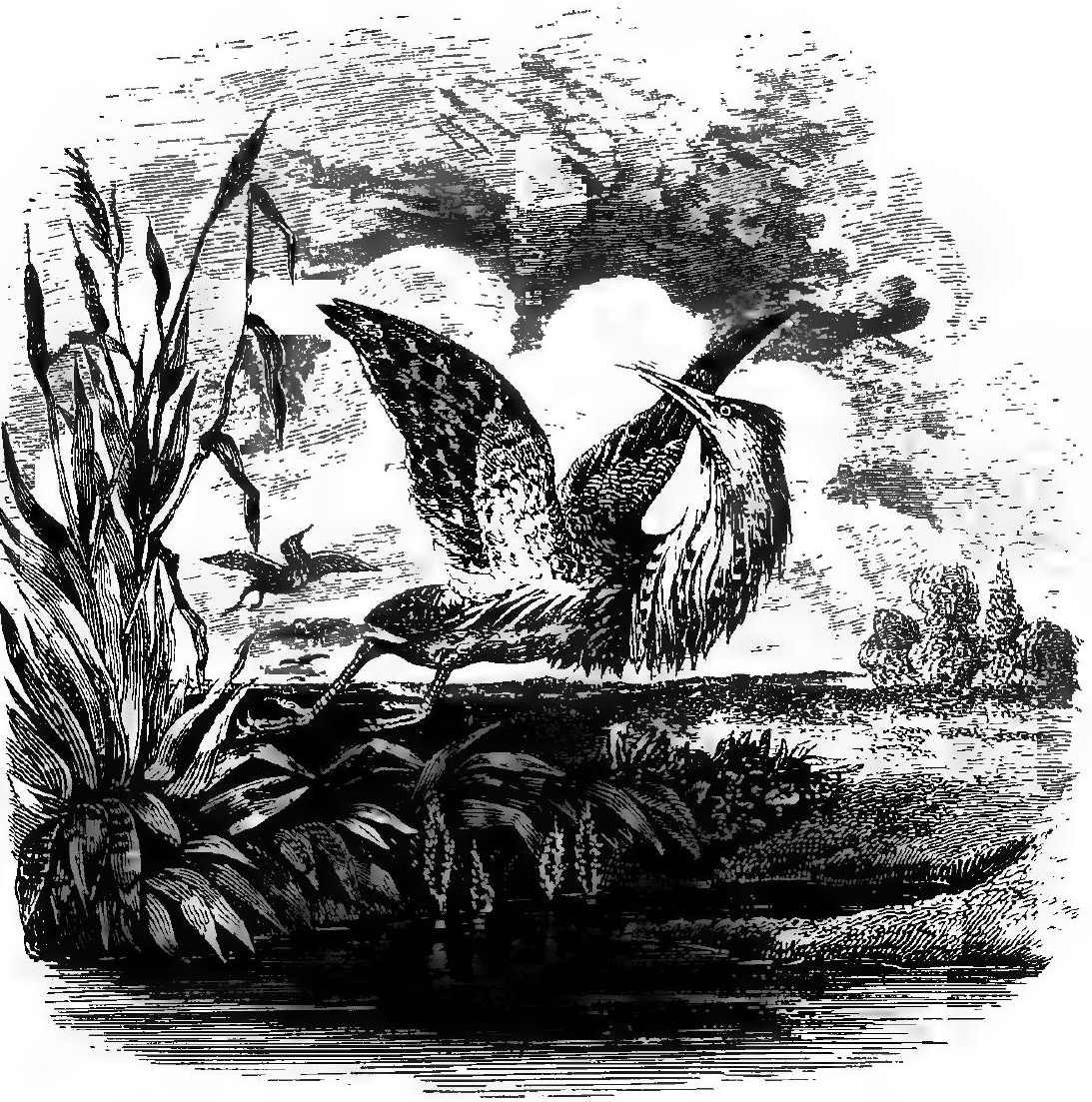

THE BITTERN. AMERICAN BITTERN. Ardea Minor sive Lentiginora. 

Now the Bittern would not probably be much aggrieved at being voted carrion, provided his imputed carrion-dom, as Willis would probably designate the condition, procured him immunity from the gun.

But to be shot first and thrown away afterward, would seem to be the very excess of that condition described by the common phrase of adding injury to insult.

Under this state of mingled persecution and degradation, it must be the Bittern's best consolation that, in the days of old, when the wine of Auxerre, now the common drink of republican Yankeedom, which annually consumes of it, or in lieu of it, more than grows of it annually in all France, was voted by common consent the drink of kings-he, with his congener and compatriot the Heronschaw, was carved by "knightly hands, upon the noble deas under the royal canopy, for gentle dames and peerless damoiselles; nay, was held in such repute, that it was the wont of prowest chevaliers, when devoting themselves to feats of emprise most perilous, to swear "before God, the bittern, and the ladies!" an honor to which no quadruped, and but two plumy bipeds, other than himself, the heron and the peacock, were admitted.

Those were the days, before gunpowder, "grave of chivalry," was taught to Doctor Faustus by the Devil, who did himself no good by the indoctrination, but exactly the reverse, since war is thereby rendered less 
bloody, and much more uncruel--the days when no booming duck-gun keeled him over with certain and inglorious death, as he flapped up with his broad vans beating the cool autumnal air, and his long, greenishyellow legs pendulous behind him, from out of the dark sheltering water-flags by the side of the brimful river, or the dark woodland tarn; but when the cheery yelp of a cry of feathery-legged spaniels aroused him from his arundinaceous, which is interpreted by moderns reedy, lair; when the triumphant whoop of the jovial falconers saluted his uprising; and when he was done to death right chivalrously, with honorable law permitted to him, as to the royal stag, before the long-winged Norway falcons, noblest of all the fowls of air, were unhooded and cast off to give him gallant chase.

. If, when struck down from his pride of place by the crook-beaked blood-hound of the air, his legs were mercilessly broken, and his long bill thrust into the ground, that the falcon might dispatch him without fear of consequences, and at leisure, it was doubtless a source of pride to him, as to the tortured Indian at the stake, to be so tormented, since the amount of the torture was commensurate with the renown of the tortured; besides -for which the Bittern was, of course, truly gratefulit was his high and extraordinary prerogative to have his legs broken as aforesaid, and his long bill thrust into the ground, by the fair hand of the loveliest lady present -thrice blessed Bittern of the days of old. 
A very different fate, in sooth, from being riddled with a charge of double Bs from a rusty flint-lock Queen Anne's musket, poised by the horny paws of John Verity, and then ignobly cast to fester in the sun, among the up-piled eel-skins, fish-heads, king-crabs, and the like, with which, in lieu of garden-patch or welltrained rose-bush, the south-side Long Islander ornanents his front-door yard, rejoicing in the effluvia of the

decomposed piscine cxuvice, which he regards as " considerable hullsome," beyond Sabæan odors, Syrian nard, or frankincense from Araby the blest!

Being eaten is being eaten after all; whether it be by a New Zealand war-chief, a New York alderman, a peerless lady, or a muck-worm; and I suppose it feels much the same, after one is once well dead; but, if I had my choice, I would most prefer to be eaten by tho damoiselle of high degree, and most dislike to be battened on by the alderman, as bei ' $g$ more ravenous and less appreciative than either Zealander or muck-worm.

The Bittern, however, be it said in sober earnest, although like many other delicious dishes prized by the wiser ancients, but now fallen into disuse, if not into disrepute-to wit, the heronschar, the peacock, the curlew, and the swan-all first-rate dainties to the wise -is a viand not easily to be beaten, especially if he be sagely cooked in a well-baked, rich-crusted pastry, with a tender and fat rump-steak in the bottom of the dish, a beef"s kidney scored to make gravy, a handful of cloves, 
salt and black pepper quantam suff., a dozen hard-boiled eggs, and a pint of scalding-hot port wine poured in just before you serve up.

What you say is perfectly true, my dear madam, cooked in that manner an old India rubber shoe is good; not only would be, but is. But you'd better believe it, a Bittern is a great deal better. If you don't believe me, try the Bittern, and then if you prefer it, adhere to the shoe.

- But now to quit his edible qualifications and turn to his personal appearance, habits of life, and location, and other characteristics, we will say of him, in the words of Wilson, that eloquent pioneer in the natural history of America, that the American Bittern, whom it pleases the Count de Buffon to designate as Le Butor de la Baye de Hrodson, "is another nocturnal species, common to all our sea and river marshes, though nowhere numerous. It rests all day. among the reeds and rushes, and, unless disturbed, flies and feeds only during the night. In some places it is called the Indian Hen; on the seacoast of New Jersey it is known by the name of dunkadoo, a word probably imitative of its common note. They are also found in the interior, having myself killed one at the inlet of the Seneca Lake, in October. It utters at times, a hollow, guttural note among the reeds, but has nothing of that loud, booming sound for which the European Bittern is so remarkable. This circumstance, with its great inferiority of size, and difference of 
marking, sufficiently prove them to be two distinct species, although hitherto, the present has been classed as a mere variety of the.European Bittern. These birds, we are informed, visit Severn river at Hudson's Bay, about the beginning of June; make their nests in swamps, laying four cinereous green eggs among the long grass. The young are said to be, at first, black.

"These birds, when disturbed, rise with a hollow kwa, and are then easily shot down as they fly heavily. Lilie other night birds, their sight is most acute during the evening twilight; but their hearing is, at all times, exquisite.

"The American Bittern is twenty-seven inches long, and three feet four inches in extent; from the point of the bill to the extremity of the toes, it measures three feet; the bill is four inches long; the upper mandible black; the lower greenish-yellow; lares and eyelids, yellow ; irides, bright yellow; upper part of the head, flat, and remarkably depressed; the plumage there is of a deep blackish brown, long behind and on the neck, the general color of which is a yellowish brown, shaded with darker; this long plumage of the neck the bird can throw forward at will, when irritated, so as to give him a more formidable appearance; throat, whitish, streaked with deep brown : from the posterior and lower part of the auriculars, a broad patch of deep black passes diagonally across the neck, a distinguished characteristic of this species; the back is deep brown, barred, and mottled with innu- 
merable specks and streaks of brownish yellow; quills, black, with a leaden gloss, and tipped with yellowish brown; legs and feet, yellow, tinged with pale green; middle claw, pectinated; belly, light yellowish brown, streaked with darker; vent, plain; thighs, sprinkled on the outside with grains of dark brown; male and female nearly alike, the latter somewhat less. According to Bewick, the tail of the European Bittern contains only ten feathers; the American species has, invariably, twelve. The intestines measured five feet six inches in length, and were very little thicker than a common knittingneedle; the stomach is usually filled with fish or frogs.* "This bird, when fat, is considered by many to be excellent cating."

It is on the strength of Mr. Wilson's statement as above that $I$ have given among the vulgar appellations of this beautiful bird that of Dunkadoo; though I must admit that I never heard him called a Dunkadoo, either on the sea-coast of New Jersey or any where else; and further must put it on record, that if the sea-coasters of New Jersey did coin the said melodious word. as imitative of its common note, they proved much worse imitators than I lave found them in whistling bay snipe, hawnking Canada geese, or yelping Brant. They might just as well hare called him a Cockatoo, while they were about it.

* I have talen an entire water-rail from the stomach of the European Bittern.-FD. 
The other name, Quawk, by which it is generally known both on the sea-coast of New Jersey, and every where else where the vernacular of America prevails, is precisely imitative of the harsh clanging cry with which he rises from the reeds in which he lurks during the day time, and which he utters while disporting himself in queer clumsy gyralions in mid air, over the twilight marshes' in the dusk of summer evenings; and how nearly Quawk approaches to Dunkadoo, that one of $\mathrm{my}$ readers who is the least appreciative of the comparative value of sweet sounds, can judge as well as I can.

In England the Bittern, who there is possessed of a voice between the sounds of a bassoon and a kettle-drum, with which he makes a most extraordinary booming noise, which can be heard for miles, if not for leagues, over the midnight marshes, a noise the most melancholy and unearthly that ever shot superstitious horror into the bosom of the belated wayfarer, who is unconscious of its canse, has also been designated by the country people from his cry, "the bog-bumper," and the "bluttery bump"-but as our bird-the United Stateser, I mean, or Alleghanian, as the New York Historical Society Associates would designate their countrymenBittern never either booms, blutters or bumps, but only quawks; a quawk only he must be content to remain, whether with the sea-coasters of, New Jersey, the southsiders of Long Island, or my friends, the Ojibwas of Livíe Hurơn. 
In another respect I cannot precisely agree with the acute and observing naturalist quoted above, as to its ungregarious nature, since on more occasions than one I have seen these birds together in such numbers, and under such circumstances of association, as would certainly justify the application to them of the word flock.

One of these occasions I remember well, as it occurred while snipe-shooting on the fine marshes about the riviere aux Canards in Canada West, when several times I saw as many as five or six flush together from out of the high reeds, as if in coreys; and this was late in September, so that they could not well have been young broods still under the parental care.

At another time $I$ saw them in yet greater numbers and acting together, as it appeared, in a sort of concert. I was walking, I cannot now recollect why, or to what end, along the marshes on the bank of the Hackensack river, between the railroad bridge and that very singular knoll named Snakehill, which rises abruptly out of the meadows like an island out of the ocean. It was late in the summer evening, the sun had gone quite down, and a thick gray mist covered the broad and gloomy river. On a sudden, I was almost startled by a loud quawk close above my head; and, on looking up, observed a large Bittern wheeling round and round, now soaring up a hundred feet or more, and then suddenly diving, or to speak more accurately, falling, plump down, with his legs and wings all relaxed and abroad, precisely as if he 
had been shot dead, uttering at the moment of each dive a loud quawk. While I was still engaged in watching his manœurres, he was answered, and a second Bittern came floating through the darksome air, and joined his companion. Another and another followed, and within ten or twelve minutes, there must have been from fifteen to twenty of these large birds all gamboling and disporting themselves together, circling round one another in their gyratory flight, and making the night any thing, certainly, but melodious by their clamors. What was the meaning of those strange nocturnal movements I cannot so much as guess; it was not carly enough in the spring to be connected in any way with the amatory propensities of the birds, or I should have certainly set it down, like the peculiar flight, the unusual chatter, and the drumming, performed with the quill-feathers, of the American Snipe-Scolopar Wilsonii-commonly known as the English snipe, during the breeding season, as a preliminary to incubation, nidification, and the reproduction of the species-in a word, as a sort of bird courtship. The season of the year put a stopper on that interpretation, and I can conceive none other than that the Quawks were indulging themselves in an innocent game of ronups, preparatory to the more serious and solemn enjoyment of a fish and frog supper.

The Bittern, it appears, on the Severn river, emptying into Hudson's Bay, makes its nest in the long grass of 
the marshes, and there lays its eggs and rears its black downy young; but several years ago, while residing at Bangor, in Maine, while on a visit to a neighboring heronry, situated on an island covered with a dense forest of tall pines and hemlocks, I obscrved a pair of Bitterns flying to and fro, from the tree-tops to the river and back, with fish in their bills, among the herons which were similarly engaged in the same interesting occupation of feeding their young. One of these, the male bird, I shot, for the purpose of settling the fact, and we afterward harried the nest, and obtained two full-grown young birds, almost ready to fly.

Hence, I presume, that, like manny other varieties of birds, the Bittern adapts his habits, even of nidification, to the purposes of the case, and that where no trees are to be found, in which he can breed, he malres the best he can of it, and builds on the ground; but it is my opinion that his more usual and preferred situation for his nest is in high trees, as is the case with his congeners, the Green Bittern, the blue heron, the beautiful white egret, the night heron, which may be all found breeding together in hundreds among the red cedars on the sea beach of Cape May. The nest, which I found in Maine, was built of sticks, precisely similar to that of the herons.

The Bittern is a more nocturnal bird than the heron, and is never seen, like him, standing motionless as a gray stone, with his long slender neck recurved, his javelin- 
like bill poised for the stroke, and his keen eye piercing the transparent water in search of the passing fry.

All day he rambles about among the tall grass and reeds of the marshes, sometimes pouncing on an unfortunate frog, a garter-snake, or a mouse, for, like the blue heron, be is a clever and indefatigable mouser; but when the evening comes, he bestirs himself, spreads his broad vans, rises in air, summoning up his comrades by his hoarse clang, and wings his way over the dim morasses, to the banks of some neighboring rivulet or pool, where he watches, erect sentinel, for the passing fish, shiners, small eels, or any of the lesser tribes of the cyprinidæ, and whom he detects, woe betide; for the stroke of his sharp-pointed bill, dealt with Parthian velocity and certitude by the long arrowy neck, is sure death to the unfortunate.

Mr. Giraurd, in his excellent book on the birds of Long Island, thus speaks of the American Bittern, and that so truthfully and agreeably withal, that I make no apology for quoting his words at length.

"This species is said to have been the favorite bird of the Indians, and at this day is known to many persons by the name of "Indian Hen," or "Pullet," though more familiarly by the appellation of "Look-up," so called from its habit, when standing on the marslies of elevating its head, which position, though probably adopted as a precautionary measure, frequently leals to its destruction. The gunners seem to have a strong 
prejudice against this unoffending bird, and whenever opportunity offers, seldom allow it to escape. It does not move about much by day, though it is not strictly nocturnal, but is sometimes seen flying low over the meadow, in pursuit of short-tailed or meadow-mice, which I have taken whole from its stomach. It also feeds on fish, frogs, lizards, etc. ; and late in the season, its flesh is in high esteem-but it cannot be procured in any number except when the marshes are overflowed by unusually high tides, when it is hunted much after the manner the gunners adopt when in pursuit of rail. On ordinary occasions, it is difficult to flush; the instant it becomes aware that it has attracted the attention of the fowler, it lowers its head and runs quickly through the grass, and when again seen, is usually in a different direction frow that taken by its pursuer, whose movements it closely watches; and when thus pursued, seldom exposes more than the head, leading the gunner over the marsh without giving him an opportunity to accomplish his purpose.

"When wounded, it makes a vigorous resistance, erects the feathers on the head and neck, extends its wings, opens its bill, and assumes a fierce expressionwill attack the dog, and even its master, and when defending itself, directs its acute bill at its assailant's eye. It dòes not usually associate with other herons, nor does it seem fond of the society of its own species. 
Singly or in pairs it is distributed over the marshes, but with us it is not abundant."

The geographical range of this bird is, as I have before stated, very extensive, extending from the shores of Hudson's Bay, in the extreme north, so far south at least as to the Cape of Florida, and probably yet farther down the coasts of the Mexican gulfs.

That fanciful blockhhead, the Count de Buffon-for he was a most almighty blockhead when he set himself drawing on his imagination for facts-with his usual eloquent absurdity, describes the species as "exhibiting the picture of wretchedness, anxiety and indigence; condemned to struggle perpetually with misery and want; sickened with the restless cravings of a famished appetite ;" a description so ridiculously untrue, that were it possible for these birds to comprehend it, it would excite the risibility of the whole tribe.

If the count had seen the Quawks, as I did, at their high jinks, by the Hackensack, he would have scarce written such folly; and had he been a little more of a true philosopher, and thorough naturalist, he would have comprehended that whatsoever being the Universal Creator hath created unto any end-to that end he adapted him, not in his physical structure only, but in his instincts, his appctites, his tastes, his pleasures and his pains ; and that to the patient Bittern, motionless on his mud-bank, that watch is as charming, as is the swift pursuit of the small bird to the falcon, of the rabbit to 
the fox, of the hare to the greyhound, of all the animals devoured to all the devourers; and that his frog diet is as dear to Ardea Lentiginosa, as his flower dew to the humming-bird, or his canvas-backs, in the tea-room, to an alderman of Manhattan.

As for the Bittern starving, eat a fat one in a pie, and you'll be a better judge of that probability, than any Buffon ever bred in France; and as for all the rest-it is just French humbug.

At another opportunity, I may speak of others of this interesting tribe. Sportsmen rarely go out especially to hunt them, except in boats, as described by Mr. Giraud, but in snipe and duck-shooting in the marshes they are constantly flushed and shot.

Pointers and setters will both stand them steadily, and cocking spaniels chase them with ardor. Their flight is slow and heary, and their tardy movements and large size render them an easy mark even to a novice. They are not a hardy bird, as to the bearing off shot; for the loose texture of their feathers is more than ordinarily penetrable, and a light charge of No. 8, will usually bring them down with certainty.

When wing-tipped they fight fiercely, striking with their long beaks at the eyes of the assailant, whether dog or man, and laying aside resistance only with their lives.

Early in the autumn is the best time both for shooting Lim and eating him, and for the latter purpose he is 
better than for the former; but for the noble art of falconry, the mystery of rivers, he is the best of all. Avium facite princeps; easily the Topsawyer of the birds of flight, unless it be his cousin german heronshaw, whom the princely Dane knew from a hawk, when the wind was nor-nor-west. 

XI.

\section{NOVEMBER.}

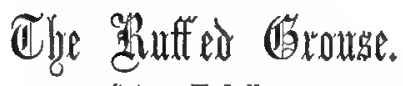 \\ Letrao Umbellus.}

\section{THE PHEASANT; THE PARTRIDGE.}

LABRADOR; BRITISH POSSESSIONS; UNITED STATES.

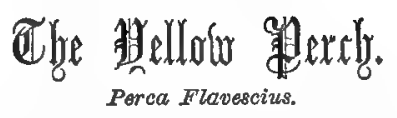

CONTINENT OF NORTH AMERICA. 




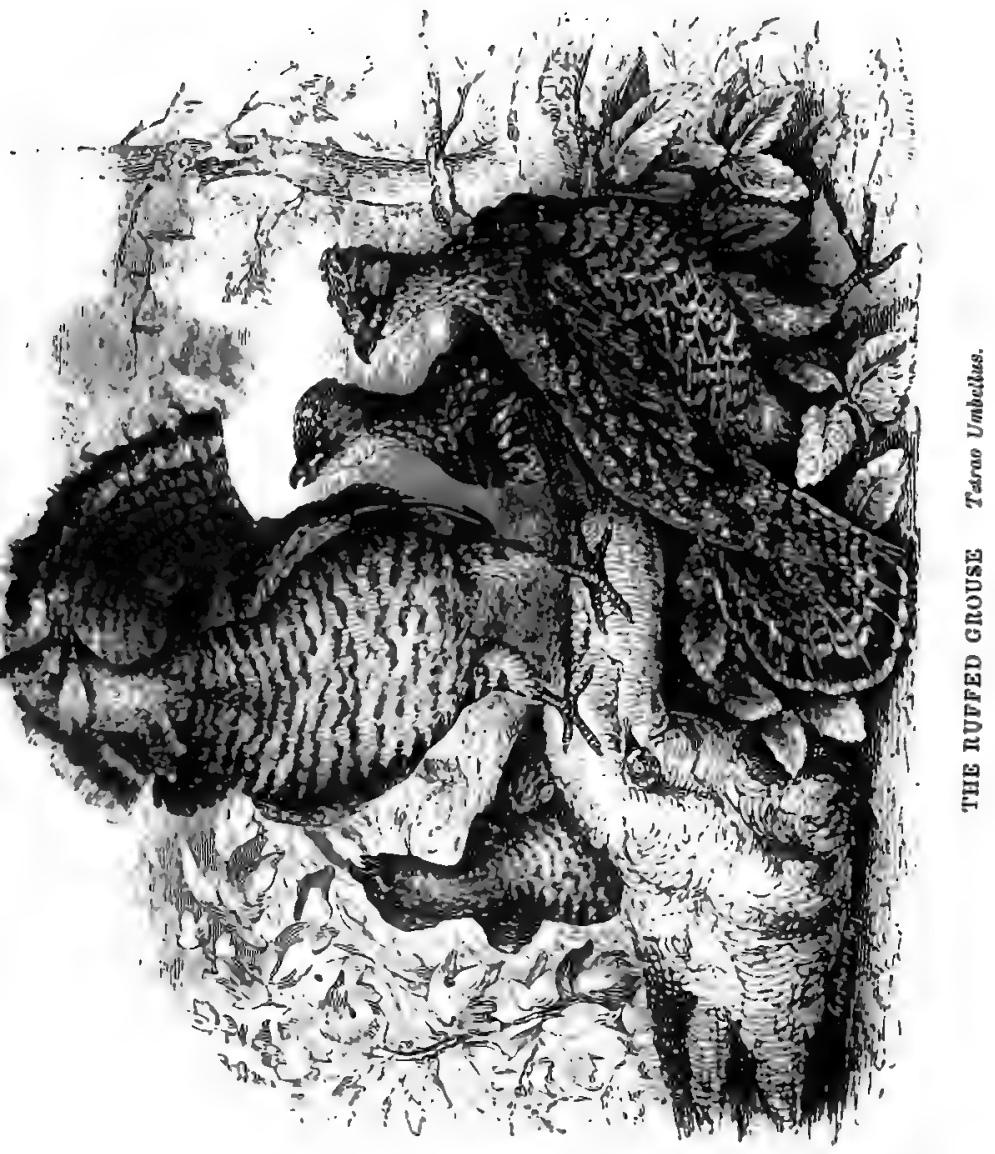




\section{THE RUFFED GROUSE.}

\section{Tetrao Umbellus.}

The beautiful bird which is depicted above, is that known as the Partridge, in New Jersey, and all the States east and north of the Delaware, and as the Pheasant everywhere to the westward of that fine stream; and by these provincial vulgarisms it is like to be known and designated, until sportsmen will take the trouble of acquiring a little knowledge of their.own trade, and will cease to regard naturalists as mere theorizing bookmen, and scientific names and distinctions as supererogatory humbug. The distinction between the Grouse and other birds of the gallinaceous order, is that the former are invariably, the latter never, feathered below the knee. This distinction never fails, and is very easily noted; although, in different species of the genus, the extent of the feathering differs. In the Ruffed Grouse the soft fleecy feathering of the leg is sparse, and descends only to the middle of the shank. In the Pinnated Grouse, Prairie Hen of the West, and Grouse of Pennsylvania, New Jersey, and Rhode Island, the legs are feathered 
the whole way down the shank, to the insertion of the toes; and the same is the case of the Canada Grouse, or Spruce Partridge of the remote Eastern States. In all those species of Grouse, which are known as Ptarmigan, dwellers of the extreme north, or in the northern temperature of iced mountain-tops, the feathering continues the whole length of the toes quite to the insertion of the claws-this I merely mention par parenthese, as there is but one of the Ptarmigans likely to fall within reach of the sportsman; namely, the Willow Grouse, or RedNecked Partridge of the extreme parts of Maine, and the Easternmost British provinces, and thence so far as to the Arctic Circle.

These distinctions are easily borne in mind, and will be found all-sufficient to the discriminating woodsman, who desires to be able to call things by their right names, and to give a reason for doing so.

The true Pheasant is a native of Asia originally, though it has been naturalized in Europe, since a very early period, and is now abundant in France and England. No species of this bird, which is distinguished by a pointed tail above half a yard in length, and by its splendidly gorgeous coloring, little inferior in intensity to that of the Peacock, has ever been found, or is believed to exist in any portion of the Western hemisphere; although those singular and showy birds, the Curacoas of South America, have some relation to it.

The same is true of the real Partridge; although the 
Quail of this continent would seem to be its equivalent; being as it were a connecting link between the European Quail, and the Partridge of Europe.

The Ruffed Grouse ranges over a very wide portion of the United States and British provinces, from the 51st degree of north latitude to the Atlantic sea-board, although it is much more scarce in the Southern States than in the midland and northern regions. It is remarkable also that it varies exceedingly in color; those to the northward being comparatively dull and gray, to those of Pennsylvania, Kentucky, and more genial regions.

The distinctive feature, whence this bird derives his title of Ruffed Grouse, is the tuft or tippet of jet-black feathers, glossed with metallic hues, which are shown more or less distinctly in each of the figures in the wood-cut at the head of this paper, but the most decidedly in the cock-bird, represented as standing on a fallen $\log$, in the act of drumming, with these ruffs elevated, and his tail erected and expanded after the manner of a Turkey or. Peacock, in the season of his amorous phantasies.

This drumming, a sound sufficiently familiar to all ears accustomed to the sights and noises of the forest, is no less than the call of the male bird to his harem of attendant wives; for the Ruffed Grouse, unlike our pretty, constant, and domestic Quail, selects himself no one fond partner, whom to cheer with his loved notes, to comfort and amuse during the breeding season, but 
rejoices like a veritable grand Signor in a multiplicity of fair sultanas, whom so soon as they betake themselves to the cares of maternity, he abandons, like a roue as he is, and passes the remainder of the season, until the broods disperse in the autumn, in company with small packs of his own faithless sex, reveling and enjoying himself on the mountain sides, in his loved pines and hemlocks, while his forgotten loves brood patient orer the hopes of the coming season.

"This drumming," says Wilson, in his eloquent and animated page, "is most common in spring, and is the call of the cock to a favorite female. It is produced in the following manner : the bird, standing on an old prostrate $\log$, generally in a retired situation, lowers his wings, erects his expanded tail, contracts his throat, elevates the two tufts of feathers on the neck, and inflates his whole body something in the manner of a Turkey cock strutting and wheeling about in great stateliness. After a few mancuvres of this kind, he begins to strike his stiffened wings in short and quick strokes, which become more and more rapid until they run into each other, resembling the rumbling sound of very distant thunder dying away gradually on the ear. After a few minutes' panse, this is again repeated, and in a calm day may be heard nearly a mile off. This is most common in the morning and evening, though I have heard them drumming at all hours of the day."

It is singular, that so exact an authority a,s Wilson 
has proved himself to be, should fall into the strange error of speaking of this singular amorous sound as a call to a single female; and elsewhere of the Pheasant, as he erroneously calls it, pairing; when it is notorious to all who have closely observed the habits of this bird, that it is polygamous. Such, I believe, will be found the case with all those gallinaceous birds which have an especial summons, or peculiar display of attitudes, airs, and splendors by which to attract the females; as may be observed of the common Game-cock, the Turkey, the Peacock, and the European Pheasant; no one of which takes to himself an especial and chosen partner, but disports himself in his wanton seraglio.

On many occasions, during this particular season, I have stolen up to within a few yards of the log, whereon the Ruffed Grouse was so busily employed in summoning his dames and demoiselles around him, that he had no ears or eyes for my approach, which at any other period he would have discovered long before, and whirred away tumultuous on terrified and sounding pinions. I have lain concealed, for an hour at a time, watching with intense gratification the beautiful and animated gestures of the cock, now strutting and drumming on his log, proud as an eastern despot, now descending to caress and dally with his numerous Roxalanas, and then reascending to his post of pride, to send his resonant call far through the haunted echoes of the umbrageous pine-woods. On one such chance, I saw no 
less than seven hen birds gathered around a single male, all in turn expectant of his looked-for attentions, and all gratified by a share of his notice. If this be not Polygamy, I should like to receive the Grand Turk's opinion on the subject, as I confess mayself, if it be any thing less, in a state of absolute benightedness.

The Ruffed Grouse begins her nest very early in May, and lays from eight to tifteen brownish-white, unspotted eggs, nearly the size of those of a pullet. With the exact period of this bird's incubation I am not acquainted; the young birds run the instant they clip the shell; obey the cluck of the mother, as chickens that of the hen; and are tended by her with extreme care and solicitude. In case of her being surprised with her young about her, she resorts to all the artifices practiced by the Quail, and even by the comparatively dull and stolid Woodcock, to draw away the intruder from the vicinity, feigning lameness, and incapacity to fly, until she shall have lured away the pursuer far from the hiding-place of her fledglings. Then she shall whirr away on resonant and powerful pinions, up, up above the tops of the tall pines and hemlocks, and thence skate homeward noiseless on balanced wings, where she will find them close ensconced among the sheltering fern tufts, or the matted winter-greens and whortleberry bushes, viewless to the most prying eye, and undiscoverable, save to the nose of the unerring spaniel. But once returned, you shall see them emerge, chirping 
feebly at the soft maternal cluck, and hurrying to enshroud them nnder the shelter of her guardian wing, and nestle, happy younglings, among the downy plumage of her maternal breast. Curses upon the sacrilegious hand that would interrupt that sweet and tender scene by the sharp click of the murderous trigger; yet there be brutes, in the guise of men, who scruple not to butcher the drumming cock, taken at fatal disadvantage, amid his admiring harem; scruple not to slaughter the brooding mother above her miserable younglings-but to such we cry avaunt! to such we deny the name of sportsmen, nay, but of Christians, or of men. Get ye behind us, murderous pot-hunters!

The young broods grow rapidly; and by the time they have reached the size of the Quail, fly well and strongly on the wing. By the middle, or latter end of August, they are three parts grown, and fully feathered, with the exception of the tail, which is not yet complete, and retains a pointed form. The blundering legislation of this country in general, on the subject of the game-laws, has, in this instance, to my ideas, exceeded itself; for during the months of September and October, when the broods are still united under the care of the mother, the birds lying well to the setter, and when flushed scattering themselves singly here and there among low undergrowth or bushes, and rarely or never taking to the tree, we are prohibited from shooting this bold, hardy, ramb- . ling, and shy bird; this, at a later season, wild hunter 
of inaccessible rock-ledges, impenetrable rhododendron brakes, and deep sequestered hemlock-swamps ; this, the most uncomatable and self-protecting bird of all the varieties of American game; the only variety, peihaps, which never can by any means, fair or unfair, be exterminated from among us, so long as the rock-ribbed mountains tower toward the skies, and the forests clothe them with foliage never sere.

At this period they would afford rare sport, as at all other seasons they afford none; and are, moreover, in far the best condition for the table, as the old birds are apt to be dry, unless hung up for several weeks before heing cooked, which can, of course, only be done in winter, when the coldness of the weather prevents their becoming tainted, without absolutely freezing them.

In my opinion, therefore, this the only bird, of American game, which might well exist apart from almost all protection, is now so protected as to be almost rendered impossible to the gun of the fair sportsman; while for others, the tamest, the most easily killed, and the most rapidly decreasing of all our winged tribes, as the Woodcock, for example, the mock protection afforded to them is but another word for the license to slaughter them half-fledged and half-grown, while the second brood is yet in the black-down, and unable to exist without the parent's care.

I would myself desire to see the legitimate season for Ruffed Grouse-shooting made to commence with the first 
day of September, the young birds by that time, and in truth much earlier, being quite fit for the gun, and to cease on the fifteenth of December, or at Christmas at the latest, before the snows of winter admit of their being snared and trapped by thousands.

Toward the middle of October, the old hens drive off the broods, or the young birds now perfectly mature, stray from them of their own accord; and thenceforth wy are found sometimes in little companies of two, three, or four, but far more often singly, in wild, difficult upland woods, through which they love to ramble deviously for miles, as they are led in search of their favorite food, or sometimes, as it would seem, by mere whim. On one occasion, many years since, when I was but a young sportsman on this side of the Atlantic, I remember footing a small party of five birds, in a light snow, for above ten miles among the Wawayanda mountains, in Orange County, New York, without getting up to them; although it was easily seen by their hurried and agitated tracks that for a great part of the distance they were within hearing of me, and were running from my pursuit. I had no dogs with me. \#ad I been out with setters, the Grouse would have trailed them for miles, and unquestionably risen at last out of shot. With spaniels, or curs, trained to run in upon them, and pursue, yelping loudly, as the mode is in the backwoods, where men do not shoot but gun, they would have taken to the trees, and would have sat close to the trunk with 
their bodies erect, and their necks elongated, and might have been killed easily, the only difficulty being that of perceiving them, a difficulty far more considerable than would be imagined to an unpracticed eye. To shoot birds sitting, however, whether on trees or on the ground, is not sport for a sportsman; the only case wliere it is ever allowable, is to the woodsman on a tramp through the primitive and boundless forest, where his campkettle must be filled by the contents of his bag, and where to throw away a chance is, perhaps, in the end to go supperless to bed. In such a case, while canoeing it last Autumn "with a goodly companye" up the northern rivers that debouch into lake Huron, we shot many, while portaging around cataracts or rapids on the Severn; and on one occasion a gentleman of the party shot three birds, out of one small pine tree, without any of them moving or appearing alarmed at the gun-shots. This has often been related as a constant and ordinary. habit of the bird; and from that occurrence, I am induced to believe that when the bird is in its natural solitudes, unacquainted with man and his murderous weapons, such may be the case; in the settlements, however it might have been when they were rare and sparse, this is the habit of the Ruffed Grouse no longer. I have never in my life, save in the instance mentioned, observed anything of the kind; on the contrary, I have ever found them the wildest, the most wary, and unless, 
by some mere chance, the least approachable of all wild birds.

During the latter autumn, they eschew flat, bushy tracts, and even swamps with heavy thickets, their instinct probably telling them that in such covert they are liable to be taken napping. If, however, one have the fortune to find them in such tracts, he is likely to have sport over setters; and in no other sort of ground do I deem that possible, as the law now stands. Once, many years since, sporting in the heary thorn-brakes around Pine Brook, in New Jersey, I found them with a friend in low underwood, and we had great sport, bagging eight brace of Ruffed Grouse over points, in addition to some eighteen or twenty brace of Quail.

In general, however, they frequent either open groves of tall, thrifty timber, with a carpet of wintergreens, cranberries and whortleberries, which constitute their favorite food; or the steep mountain-ledges, under tho interlaced branches of tall evergreen trees, among brakes of mountain rhododendron, or, as it is commonly called, though erroneously, laurel. In both these species of ground, all being clear below, the birds can hear and see the sportsman long before he can approach them, and take wing, for the most part, entirely out of gun-shot range. If, however, they are surprised unawares, they have a singular tact of dodging behind the first bush, or massive trunk, and flying off in a right line, keeping the obstacle directly between the sportsman and 
themselves, so as to -frustrate all his efforts to obtain a shot; this I have seen done so often as to satisfy me that it is the result, not of chance, but of a deliberate instinct.

The Ruffed Grouse rises, at first, when surprised, with a heary whirring and laborious flutter, and if taken at that moment within range, is easily shot; he rises for the most part a little higher than the head of a tall man, and goes away swift and strong nearly in a horizontal line. If struck behind, he will carry away a heary load of shot, and he has a trick of flying until his breath leaves him in the air, and then falls dead before he strikes the ground. Occasionally he towers up with the wind, and then setting his wings, skates down before it at a prodigious rate, without moving a feather; and, if you get a shot at him, gentle reader, under such circumstances, crossing you at long range, be sure that you shoot two, or, by 'r lady, three feet ahead of him, or you may cut off his extreme tail-feathers, but of a surety kill him you shall not.

The Ruffed Grouse usually flies in a perfectly right line, so that if you flush one without getting a shot, and can preserve his line exactly, you may find him, if he have not treed, which it is ten to one he has; wherefore I advise you not to follow him. The exception to this right line of flight, is when the ground is broken into ridges with parallel ravines, in which case the bird, on crossing a ridge at right angles, will rarely cross the 
ravine also, but will dive up or down, as the covert may invite.

When birds lie in narrow ravines, filled with good covert, by throwing the guns forward on the brow of the ridges a hundred yards ahead of the dogs, which must be left belind with a person to hunt and restrain them, and letting the sportsmen carefully keep that distance in advance, going very gingerly and silently, sport may be had; and so I think only-especially over slow, mute, cocking spaniels, for as the birds, after running before the dogs, will be likely to take wing abreast of, or perhaps even behind the unexpected shooter, who has thus stolen a march on them, and as they rarely, if ever, cross the ridges, but fly straight along the gorge, they so afford fair shots.

For my own part, I do not consider it worth the while, as the law now stands, to go out in pursuit of Ruffed Grouse with dogs, where you expect to find no other species of game; for, in the first place, they ramble so widely, that there is no certainty of finding them within ten miles of the spot where you may have seen them daily for a month; and, secondly, if you do find them, there is no certainty of having sport with them, but rather a probability of reverse. As an adjunct to other kinds of shooting they are excellent, but as sole objects of pursuit, I think, worthless. I have often blundered on them by chance while hunting for other game; but 
when I have gone out expressly in-pursuit of them, I have never had even tolerable sport.

If the law were altered, and September shooting permitted, the case would be altered also; and in many regions of our country, as the Kaatskill Mountains, and some parts of Columbia and Saratoga counties, in New York; the Pocono Mountains, and the Blue Ridge, generally, in Pennsylvania; and many districts of Maine, Massachusetts, Connecticut, and Rhode Island, rare sport might be had. For September shooting, No. 8 shot will be found sufficient; but after that, No. 7 ; and very late in the season, Eley's wire cartridges will be found the most effective.

This widely extended bird is too well know to require any peculiar description; and I shall content myself with observing, in aid of my portraiture of the Ruffed Grouse, that the upper part of its head and hind neck are reddish-brown, the back rich chestnut, mottled with heart-shaped spots of white, edged with black. The tail is bright reddish-yellow, barred and speckled with black, and bordered by a broad, black belt between two narrow white bands, one at the extremity of the tail. The iris of the eye hazel, bill brown, feet brownish gray. Loral band cream color. Throat and fore-neck, brownish-yellow. Tpper ruff-feathers barred with brown. Wings brownish-red, streaked with black.' Breast and abdomen cream colored, closely barred above, and laterally spotted below, with dark chocolate. Length 18 
inches, spread of wings 2 feet. The Rufted Grouse is a capital bird on the table. The breast white meat, back and thighs brown. It should be roasted quickly, eaten with bread sauce and fried crumbs, and washed down with sherry or red wine. 


\section{THE PERCH.}

The Yellow Perch; Perca flavescens.

This fine fish, which belongs to the family Percoidoe, of the division Acanthopterygii, or thorny-finned, is the common perch of the waters of the United States; ranging from the extreme east' to the extreme west of the continent; from the streams and pools of Nova Scotia and New Brunswick, to the feeders of Lake Superior and the northern tributaries of the Canadian lakes.

To the northward, it is not found in the rivers flowing into the Arctic Ocean or Hudson's Bay, and its southern limit is ill-defined, and can scarcely be ascertained, except by personal inspection; since the denizens of the southern waters have been disfigured by appellations, local, provincial, and most unscientifical, so barbarous as to defy the most intelligent inquirer.

The title of the division Acanthopterygii, or thornyfinned, is founded on the principle that every genus and sub-genus thereof has one or more of the fins supported 


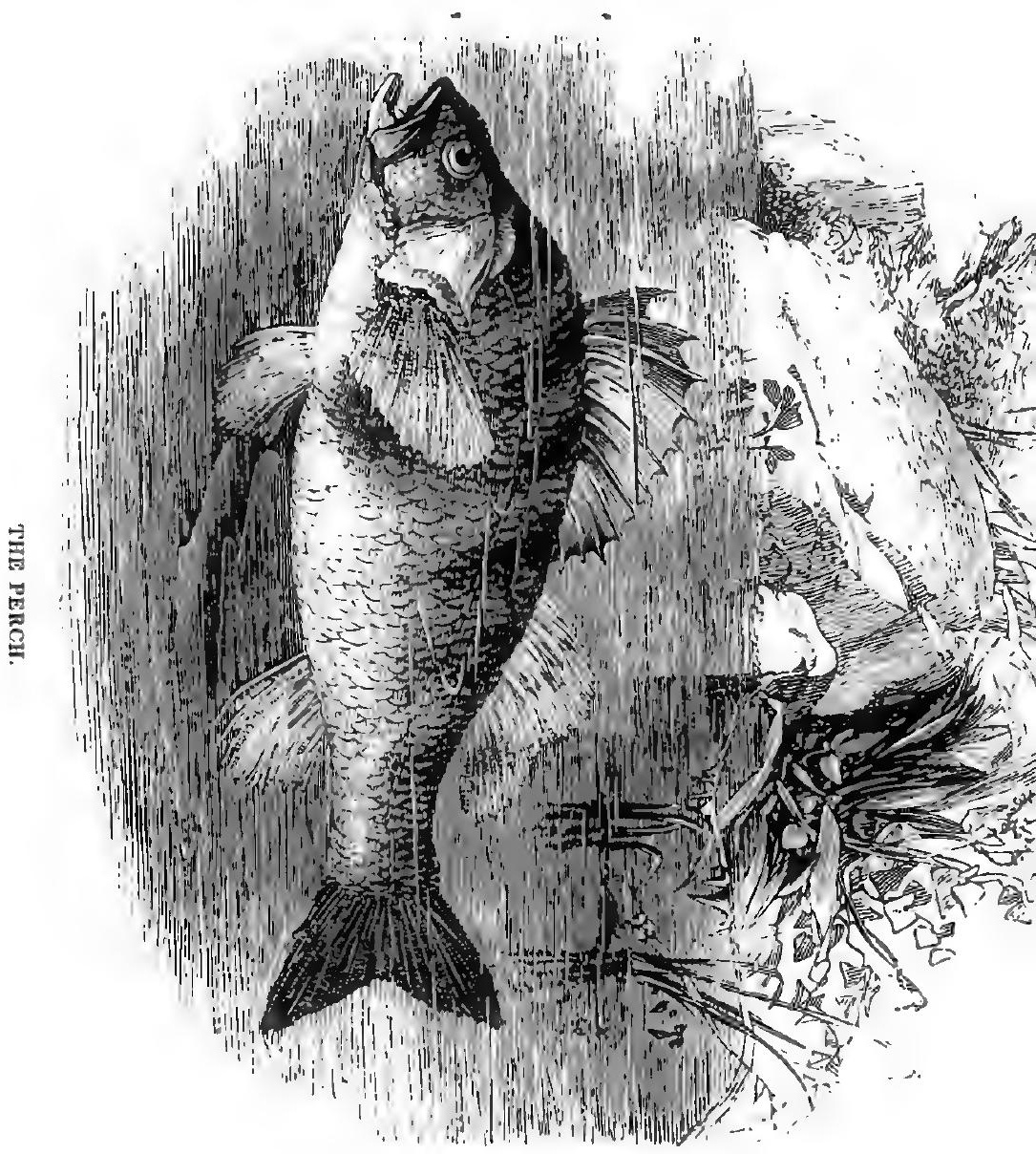



on, or preceded by, strong, sharp spines, capable of inflicting a severe wound, and forming a very efficient weapon of defense, so that the boldest and most voracious of fishes rarely venture to seize them. All the genera have two dorsal fins-the first, or foremost, of which is invariably supported on spines, as opposed to soft branched rays; while the second, or hindmost, is of soft texture, preceded by one or more hard spines-two pectoral fins, both soft-rayed-one ventral, and one anal, each of which is often preceded by one or more spines -and one caudal, or tail fin, which is the main propelling power of the animal. On the number of the hard spines supplementary to the soft fins, are founded the different families; and on the number of spines in the first dorsal, the dental system, and some other parts of the bony structure, the lesser, or individual distinctions. On color, as distinctive of genera, or even varieties, little or no reliance can be placed, unless confirmed by distinct variations in the bony formation; since in all fishes there is observed to exist a great range of hues, shades, and even positive colors, arising sometimes from mere casual influences operating on individual specimens, sometimes from accidents of light or shade affccting peculiar situations, and most frequently of all fiom the soil and character of the feeding-grounds, and from the various mineral or earthy substances held in solution by the waters they frequent.

These latter influences frequently modify the same 
fish in different streams, even of the same region and neighborhood, and flowing over soils apparently identical, to such an extent, that the casual observer not unnaturally believes them to be distinct varieties, if not species, and can be with difficulty convinced, on the immutable evidences of structural sameness.

This fact has led, in a great measure, to the complicating and confounding the science of Natural History, by the undue multiplication of names, species, and genera, where no specific differences exist; rendering the science infinitely difficult to the beginner, and causing the unlearned to undervalue the lore of the naturalist, and to deny the reality of all scientific distinctions whatsoever.

On differences of structure, such as the situation and texture of the fins, the number of spines or soft rays in each, the form of the gill covers, the character and position of the teeth, perfect reliance may be placed, as indicating unchangeable specific characteristics, by observation of which the educated naturalist will name at a glance the species, genus and sub-genus of any fish, unseen before; and will unerringly determine his habits, his food, and in some degree his habitation.

Thus of the Percoid family we distinguish the subgenera Perca, perch proper, from Gristes and Centrarchus, to which are referred the types black basse of the lakes, and the little rock basse of the St. Lawrence basin, by the fact that the Percos have one spine to the 
ventrals and two to the anal. The Gristes one to the ventrals and three to the anal. The Centrarchi one to the ventrals and six to the anal.

And in like manner, by the number of spines supporting the first dorsal, we are enabled to pronounce on the - truth or untruthfulness of the many subdivisions of the perch family, as predicated by the fishermen of various regions, and insisted on by credulons naturalists, such as

- Dr. Smith, of Massachusetts, whose book is rendered absolutely valueless by the readiness which he displays in adopting every local legend concerning new varieties, and classifying new species; until, if we believe him at all, we must believe that every several stream rnd pool from Maine to Minnesota has its own distinct variety of perch ; nor of perch only, but of trout, and, more or less, of every finny tenant of the waters.

The truth appears to have been at length firmly established, and to be this-that there is but one clearly defined and distinct perch, perca flavescens, the yellow perch, found in the United States-that the perca fluviatilis, common river perch of Europe, does not exist at all in American waters, though it is so closely connected with our fish that a casual observer would pronounce them identical-that the supposed subgenera of perca granulata, or rough-headed perch, perca argentea, silver perch, perca acuta, or sharp-nosed perch, and perca gracilis, said to be peculiar to the small lakes of Skaneateles, in the interior of New York, are not sufficient- 
1y made out as permanent varieties; and that the variations of color from dark, green and greenish brown, to bright yellow, silvery, and something nearly approaching to orange, are merèly local, casual, and individual differences, and not general, permanent, specific distinctions.

The following luminous description of this game and excellent fish is borrowed from Dr. Richardson's Tauraboreali-Americana, or natural history of the Northern Regions of America, including parts of the United States, and the British Provinces as far north as to the Arctic Ocean. The specimen from which it was compiled was caught at Penetanguishine, on the great Georgian bay of Lake Huron, but will answer for fish of this genus taken in any part of America which they may chance to frequent; so small is their variation in any respect but that of color, which appears to vary in obedience to no fixed law of locality or latitude, except that it appears to me that of the fishes taken in estuaries and at the mouths of tidal rivers, the color is deeper and the tints fade from cerulean black along the dorsal outline to olive green on the flanks, with a silver belly; while in clear lakes and fresh streams, they change from olive-green on the back to bright golden yellow on the sides and belly.

\section{THE YELLOW PERCH.}

Color.-General tint of the back greenish-yellow; of the sides golden-yellow with minute black specs; and 
of the belly whitish. Nine or ten dark bands descend from the back to the sides, and taper away toward the belly; the alternate ones are shorter, and on the tail and shoulders they are less distinctly defined; the longest band is opposite to the posterior part of the first dorsal fin, on which there is a large black mark.

Form.-The body is moderately compressed, its greatest thickness being somewhat more than one half of its depth. Its profile is oblong, tapering more toward the tail, which is nearly cylindrical : its greatest depth is at the ventrals, and rather exceeds one-fourth of the total length, caudal included.

The head constitutes two-sevenths of the total length, and its height, at the eye, is equal to ono-half its length from the tip of the snout to the point of the gill-cover. The forehead is flat, but appears depressed, owing to the convexity of the nape. The snout is a little convor. The orbits are lateral, distant more than one of their own diameters from the tip of the snout, and more than two diameters from the point of the gill-cover. The jaws are equal. The mouth descends as it runs backward, its posterior angle being under the centre of the orbit.

Teeth.-The intermaxiliaries, lower-jaw, knob of the vomer, and edge of the palate-bones, are covered with very small, straight or slightly-curved, densely-crowded teeth (en velours.) The vault of the palate, posterior part of the vomer, and the pointed tongue, are smooth.

Gill-covers.-The preoperculum is narrow; its upper 
limb rising vertically forms a right-angle with the lower one; and its edge is armed with small spinous teeth, those on the lower limb being directed forward. The bony operculum terminates in a narrow sub-spinous point, beneath which there are three denticulations, with grooves running backward from them. An acutepointed membranous flap prolonged from the margin of the suboperculum conceals these parts iu the recent fish. The edge of the interoperculum and posterior part of the suboperculum are minutely denticulated. The edges of the humeral bones are slightly grooved and denticulated, the denticulations being more obvious in some individuals than in others.

Scales.-There are sixty scales on the lateral line, and twenty-two in a vertical row between the first dorsal and centre of the belly. The scales are rather small, their bases truncated and furrowed to near the middle (striées en éventait) by six grooves corresponding to eight minute lobes of the margin. $\dot{A}$ narrow border of the outer rounded edge is very minutely streaked, producing teeth on the margin, visible under a lens. The length and breadth of a scale, taken from the side, are about equal, being two and a half lines. A linear inch measured on the sides or belly, longitudinally, contains twelve scales, the scales on the belly having, however, less vertical breadth. On the back an inch includes seventeen or eighteen. The asperity of the scales is perceptible to the finger, when it is drawn over them from the tail 
toward the head. The lateral-line is thrice as near to the back as fo the belly, and is slightly arched till it passes the dursal and anal fins, when it runs straight through the middle of the tail. It is marked on each scale by a tubular elevation, which is divided irregularly by an oblique depression.

Fins.-Br.7-7; D. 13-1|13; P. 14; V. 1|5;A. $2 \mid 8$; C. $175-5$.*

The first dorsal commences a little posterior to the point of the gill-cover and to the pectorals : its fourth and fifth rays are the highest: the first ray is slender and not half the height of the second; the last ray is so short as to be detected only by a close examination. The second dorsal commences a quarter of an inch from the first, the space between them being occupied by two or three inter-spinous bones without rays : its first ray is spinous, and is closely applied to the base of the second, which is thrice as long, distinctly articulated, and divided at the tip; the remaining rays are all divided at their summits, but at their bases the articulations are obsolete. The pectorals originate opposite to the spinous point of the operculum; they are somewhat longer than the ventrals, which are attached opposite to the second spine of the first dorsal. The anal is rounded: its first

* Br. represents the rays within the gill-covers, which form the breathing apparatus of the animal $-D$. the dorsals $-P$, pectorals $-V$. ventrals-A. anal-C. caudal. The notations $1|13,2| 5$, and $2 \mid 8$, c. ppectively indicate one hard spine, thirteen soft rays, etc. etc. 
ray is one-fourth part shorter than the second, both being spinous : the succeeding rays are articulated and branched, the five anterior ones being longer than the second spine, the others becoming successively shorter: its termination is opposite to that of the second dorsal. The caudal is distinctly forked, its base is scaly, the scales advancing farther on the outer rays and covering one-third of their length.

Such is the general description of the fish throughout the country at large, but great allowance must be made for accidental and local variations of color, some specimens being light green, backed and barred with black, with silvery bellies, others exactly as portrayed above, others nearly orange, and approaching in some degree to the splendor of the gold-fish.

As I have observed, no fish is more general than this, in every description of waters throughout his range in the United States. From the largest rivers, so low down their channels that, the waters begin to be brackish, to the smallest mountain rivulets; from the mill-pond, and small, clear mountain tarn, to the vast expanses of Huron, Michigan and Superior, they are omnipresent and numerous.

They spawn in March, each female exuding a vast quantity of spawn. So many as 992,000 ora having been taken, as it is stated by Mr. Brown in his "American Angler's Guide," though he does not annex his authority, from a single female. 
They may be taken during every month of the year with the hook, being bold biters and among the most voracious of all fishes, devouring the spawn and young fry of their own species with savage avidity, and being among the most deadly foes to the trout preserves, owing to the rapacity with which they ransack the spawning beds.

They are in the main a lively and active fish, roving about in small bands or shoals, sometimes swimming high and near the surface, leaping merrily at the flies and smaller water insects, and sometimes, especially in clear, rapid scours of gravel-bedded rivers, sweeping along the bottom, gathering the small, red brandling worms, of which they are very fond, caddises, and otluer water reptiles, as well the spawn of such fish as use these localities.

The larger fish will, however, often select stations, . such as the lee of a large stone at the tail of a ripple, especially under the umbrage of trees growing on the bank, or among the piles and timbers of mill-dams or sluice-ways, whence they sally out like the pike or trout on any passing prey with great velocity and accuracy of aim. Still even these are decidedly gregarious, as one is never found singly in a hole, such places being invariably frequented by such a band as it will liberally support, who rarely stray beyond its limits, and prey, for the most part over the same fishing-ground, and in the same course. 
This propensity is taken advantage of by the angler, since, when he has once struck upon a well-stocked haunt, while the fish are in the humor to bite, he will be very apt, if paticnt and skillful, to take the whole shoal without the loss of a single fish.

The growth of the yellow perch is slow, and appears to be proportioned pretty accurately to the size and character of the waters which he frequents. In small, swift-running brooks, or little spring-ponds or mill-dams, he rarely exceeds a few inches in length and a few ounces in weight, partaking generally of the green and silvery type of the fish. In estuaries and large rivers, in the pellucid tarns and lakelets, which are dotted so beautifully through all the uplands of the eastern and middle states from Maine to Pennsylvania, in the vast expanses of the great northern lakes of Canada, in the giant rivers of the west, they attain far more rapidly to a great size, three or four pounds being a run by no means unustral, and individuals being not unfrequently taken up to five, six and seven pounds, when they are very firm, fat, and in capital condition for the table.

They may be caught in all months of the year. Mr. Brown considers that they "may be had in the largest quantities and in the finest condition from May to July;" but from my own experience, which has been limited principally to the lakelets of Maine, to Greenwood or Waiwayanda lake, in Orange county, New York, to Lake Hopatkong, desecrated into Brooklyn pond, in 
Sussex county, New Jersey, and to some of the north eastern streams and ponds of Penxsylvania, I should say that late in the autumn-

When the maple boughs are crimson,

And the hickory shines like gold,

And the noons are sultry hot,

And the nights are frosty cold;

They bite with greater freedom, show more sport, and are better on the table than at any other season of the year.

The yellow perch is a bold, nay! a savage biter, and a greedy feeder; it is even recorded of him that he has been known to strike at his own eye, casually torn out by the point of the hook, which is to me by no means incredible.

Securely weaponed by the sharp palisade of arrowy spines bristling along his back, and by the stout jagged thorns protruding in advance of his ventral anal fins, when of any considerable size, he fears neither the tremendous rush and shark-like jaws of the savage mascalonge, nor the terrible agility and dauntless daring. of the namaycush and siskawity, those vast lake trouts, but feeds himself, a lesser tyrant of the waters, on whatever crosses his path of havoc.

A light, stiff, ten-foot rod, with a small reel, and twenty-five or thirty yards of line, with a small cork float, and a proper sinker for bottom tishing, is the best 
implement; and the best baits for this method are the common ground-worm or the little scarlet brandling. The latter particularly in rapid channels and scours. Cheese pastes are also used, and at times successfully, but I do not advocate their use, but the most certainly deadly of all baits is the paste made from the preserved roe of any fish which frequents the waters you are to fish. Trout-roe, in lakes or rivers haunted by that gamest and best of all the inhabitants of the water, kills unerringly.

In brackish water shrimp beats the-world for perch, remembering that you fish near to or upon the bottom.

Perch, especially when of large size, may be trolled for as pike, with the hind legs of a frog, or with any small fish on a gorge hook. But in my opinion the prettiest of all modes of catching them is to rove for them with the live minnow.

For this purpose you take a fine, clear, gut leader, with a No. 9 Limerick hook whipped on at the tail, and an inch and a half above it, and back to back to the tail hook, a second one size smaller than the first. The upper should be hooked securely into the lower jaw of a moderate sized minnow, and the lower into his dorsal fin, care being taken not to pierce his back, when he will swim about naturally and gayly for many hours, if not taken by a fish, and if carefully released without laceration, will survive the operation. A small cork, or what is better, quill-float, is necessary to this method, and a 
few shot, sufficient to sink the bait to within three inches of the bottom. When a bite is felt, a little time should be given before striking: when struck, the perch is surely taken, for though he pulls hard for a short time he has neither the fierce courage nor the wily craft of the trout, but succumbs after a few brief struggles. A reel is necessary, and the float often dispensed with by veterans in the art.

The following very graphic extracts, on perch fishing in the waters of the Niagara river and Lake Erie, are from the pen of probably the best piscatorial writer of the United States, long an esteemed correspondent of the Buffilo Commercial Advertiser, from whose lucubrations I have borrowed largely in my larger works on "Fish and Fishing," and to whom I gladly record my obligation:

"The Yellow Perch. This beautiful and active fish is almost omnipresent in the fresh waters of the Northeru States. There are probably two distinct but similar species in our country, hlended together under this common name. The perch of New England differs from ours principally in the shape of the head. In the Saratoga Lake, Owasco Lake, Cayuga Outlet, the Flats of Lake Huron, and many other localities, the perch is larger than with us, frequently weighing three pounds. Among the perch of our streams and rivers, a half-pounder is a very portly citizen-though on a few particular bars they are sometimes taken in considerable numbers, 
averaging nearly a pound each. It is almost always to be had, from earliest spring to the commencement of winter; and when poor Piscator has had all his lobsters* taken by the sheeps-head, and utterly despairs of bass, he can, at any time, and almost any where, in our river, bait with the minnow and the worm, and retrieve somewhat from frowning fortune, by catching a mess of perch.

- "In the spring, as soon as the ice has left the streams, the perch begins running up our creeks to spawn. He is then canght in them in great plenty. About the middle of May, however, he seems to prefer the Niagara's clear current, and almost entirely deserts the Tonawanda, and other amber waters. You then find him in the eddies, on the edge of swift ripples, and often in the swift waters, watching for the minnow. As the water-weeds increase in height, he ensconces himself among them, and, in mid-summer, comes out to seek his prey only in the morning and toward night. He seems to delight especially in a grassy bottom, and when the black frost has cut down the tall water-weeds, and the more delicate herbage that never attains the surface is withered, he disappears until spring-probably secluding himself in the depths of the river.

"The back fin of the perch is large, and armed with strong spines. $\mathrm{He}$ is bold and ravenous. He will not give way to the pike or to the black bass; and though

* By lobsters the writer means the small fresh-water crayfish. 
he may sumetimes be eaten by them, his comrades will retaliate upon the young of his destroyers.

"The proper bait for the perch is the minnow. He will take that at all seasons. In mid-summer, however, he prefers the worm, at which he generally bites freely. He is often taken with the grub, or with small pieces of fish of any kind.

" Fe is a capital fish at all times for the table. His flesh is hard and savory. He should be fried with salt pork rather than butter, and thoroughly done. He makes good chowder, thongh inferior for that purpose to the black bass or the yellow pile.

"A difference of opinion exists among our most tasteful icthyophagists, as to whether this fish should be scaled or skinned. Let me tell you how to skin him. Take a sharp pointed knife, and rip up the skin along the back, from the posterior extremity of the back fin, on one or both sides of it, along its whole length-then take the fish firmly by the head with the left hand, and with the right take hold of the skin of the back near the head, first on one side and then on the other, and peal it down over the tail. This being done, all the fins are thereby removed except those of the back and belly, which are easily drawn out by a gentle pulling towards the head. Cut off the head, and you have a skinless, finless lump of pure white flesh. Some say this is the only way a perch should be prepared for the cook's art-others sa.y it impairs the flavor, and should never be pursued. As 
for me, I say, ' in medio tutissimus ibis,'--neither of the disputants is infallible. Much, very much of the sweetness of the perch, and, indeed, almost all fishes, resides in the skin, which should never be parted with except for some special reason; therefore, as a general thing, I scale my perch. But, in summer, the skin of the perch is apt to acquire a slightly bitter taste, or a smack of the mud-therefore, in summer, I skin my perch."

Before quitting this subject, I will simply point out that the excellent little pan fish taken in salt water, near the turn of the tide, in most of our large rivers, and usually known as white perch, or silver perch, is not a perch, but the little white, or the little red bass. And herewith, good-night; and good luck to the gentle friends and good fishermen all who read Graham. 


\section{XII.}

\section{DECEMBER.}

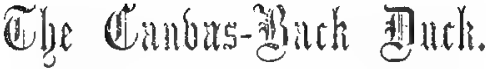

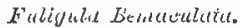

MASSACHUSETIS SOUTH TO THE CHWAPEAKE; WEST TO THE MISSISSIPF.

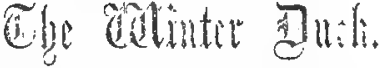 \\ "ruligula Bissuculitel.}

ARCTIC REGIUNS TO THE ST. LAWRENCE AND LAKE MICIIinisi. 




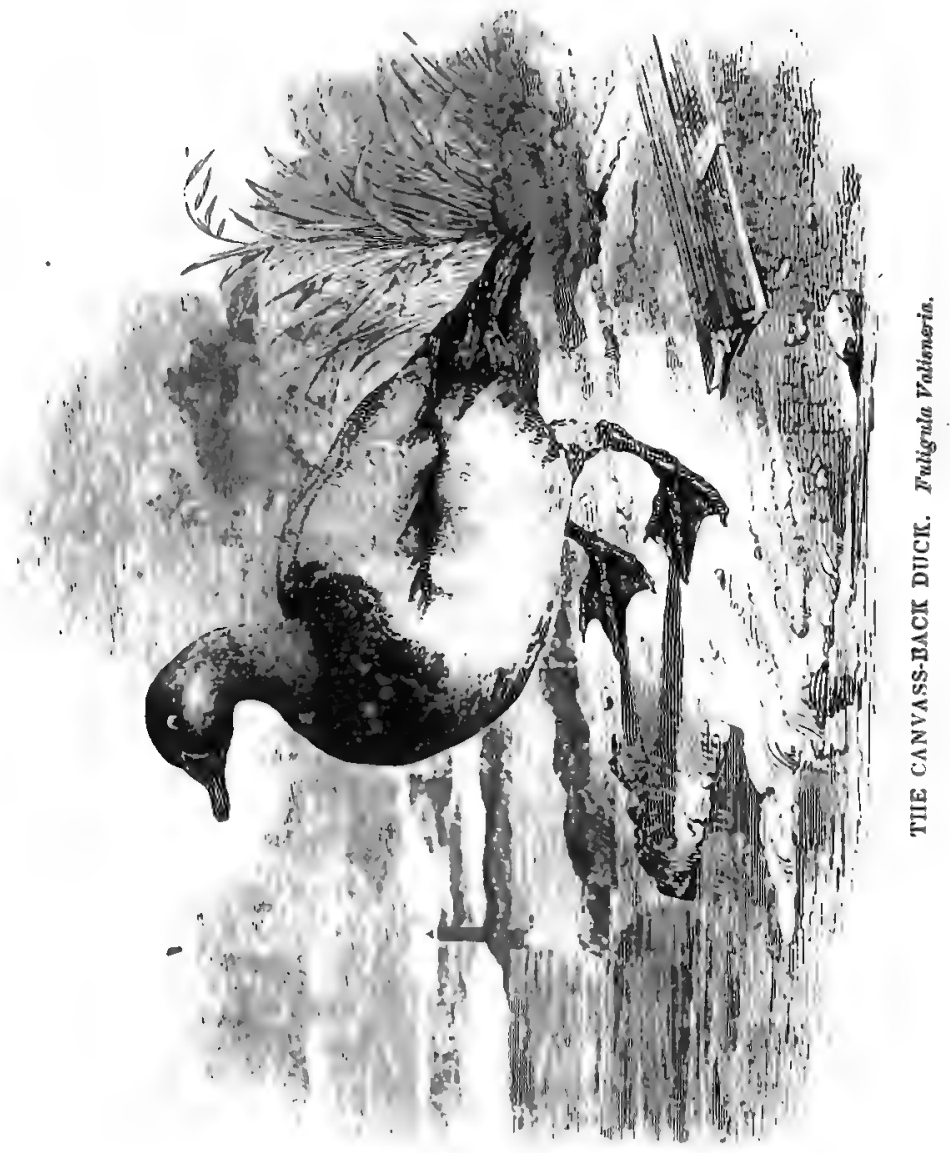




\section{THE CANVAS-BACK DUCK.}

\section{Fuligula Valisneria.}

OF a truth this is the royalty of Ducks. No other water-fowl to him is equal, or second, or in anywise com. parable; and the unlappy man who pictures to himself, in the vain imaginings of his own heart, that he is a gourmet; that he is blessed with a refined, delicate, discriminating palate; that he is capable of criticism, nay, of accumulated judgment, upon edibles, not having tnsted yet a Gunporder River Canvas-Back, reeking from the spit, with no condiment, save a modicum of salt and a stick of his bird's kindred plant, the celery, may go back to his rudiments; for when he shall once have been blessed with fruition of that rare mouthful, he will be compelled, how reluctant soever, to admit that all his boasted knowledge is but the knowledge of his own woful ignorance.

And while we are speaking of our king of water-fowl, 
as seen and felt upon the board, not yet in his grander and nobler capacity and character, as game in the free air, or on the liberal waters, let us observe that the cook who sends this glorious fowl red-raw up to the table, to be cut up butcherly and bedeviled in a chafing-dish, with wine and jelly, and I know not what, is worthy of a rope and the nearest lamp-post-death without benefit of clergy. The man who would so condescend to eat him, his juicy, melting, natural riclness disguised by cloying artificial sweetness, deserves incontinently to be elected a New York alderman, and doomed to batten, life-long, at the corporation tea-table; nor can we conceive a doom more hideous or intolerable to be endured by any rational, much more refined or thinking man, than such a condemnation; whether we regard the quality of the gross feeders and fowl-livers with whom he would have to consort, or the nature of the ill-cooked ill-assorted, rank and racy viands which he would be compelled to absorb.

No! let the kitchen be the kitchen, and its work be done within its own confines. Let the duck, roasted to a turn, redolent of a rapid tire, and brownly, nay, but almost blackly crisp without, be served up on its lordly dish, without one gout of sance or gravy to dim the splendor of the sheeny porcelain. A vase of celery may accompany him, and, if you will, a salver of halved lemons, but no more. Let him be placed before the right man of the company, one competent to 
Carve him as a dish for gods,

Not hew him as a carcass for the hounds."

Then, if he be indeed the very man, it is a pleasure in itself to observe him: Mark how dantily between his thumb and forefinger only he poises the elaborate and burnished steel; how dexterously and without effort he slides it through the rich scarlet muscle, glowing like a ripe pomegranate when its skin is severed, through cartilage and joint unerring-

"And as he draws his trenchant steel away, Mark how the blood of Casar follows it,"

till the broad dish, of late so bright and stainless, is filled even to o'erflowing with the rare, crimson gravy, and the whole atmosphere of the dining room is perfumed with the noble fumet.

And, now to descend from no inappropriate raptures to the world of common sense and the terrestrial limits of Duckdom, be it known, that all this delicacy of flavor, all this rare juciness and melting pinguidity, are attributable solely to the nicety and gentlemanly habits of your Chesapeake Canvas-Back, in that he feeds, reversing the modus operandi of my friends, the knights of the tea-table, wisely, but not too well. Your Canvas-Back of the Chesapeake Bay, but more especially of the Gunpowder river, is the nobleman of that ancient dominion; whereas, all other Canvas-Backs, even of the James, the $14 *$ 
Potomac, and the Patapsco, shall be at once' distinguished as mere parvenues and merchant princes; as- those from the Hudson, the Sound, or the great South Bay, rank as the mere snobs and vulgarians-the very outcasts of Duckdom.

The wonderful difference which exists between these fowl, when shot on the waters of the Chesapeake and elsewhere, arises solely from the difference of their food. The Canvas-Back ranges across many degrees of this continent, from the Falls of St. Peter's on the Upper Mississippi, whence I possess a pair of tine stuffed specimens, sent to me by my friend Mr. Sibley, now M. C. for Minnesota, corresponding in every particular with the same birds from the southern estuaries, so far north as the Long Island Sound, and the great lagoons between its southern side and the outer beaches on which I have frequently killed it. But nowhere is it a superior dnck, except on the waters and tributaries of the Chesapeake, where its favorite food, the wild celery, as it is incorrectly called, Zostera Valisneria, or Valisneria -Americana, grows in the greatest abundance, and imparts to it that peculiar richness and delicacy, which it bestows on none of its congeners, fhough all these, too, it wonderfully improves, particularly the Widgeon, or Baldpate, Anas Americana, regarded as second to it longo intervallo, and the Red-Headed Duck, or Pochard, Fuligula ferina, which may be regarded as its cousin german. While speaking of the birds in this relation I may mention that 
the Red-Head, thongh immeasurably inferior to the Canvas-Back, where both can feed on the valisneria, is as far superior to it when shot on sea-ways where both are compelled to feed on other species of sea-grass and weeds. Indeed, I consider the Duskey Duck, commonly known as the Black-Duck, a better bird on the Northern Atlantic sea-board than this fowl.

The valisneria of which it is so fond, and to which it owes so much of its excellence, grows only on fresh shoals, in water from seven to nine feet, which are never left bare at the lowest tides. It is a long grass-like plant, with narrow leaves of five or six feet in length or upward, and is said to grow so thickly that a boat can scarcely be pulled through it; the root is white, and somewhat resembles celery, whence its common name, and on this only do the ducks feed, the Canvas-Back and Scaup-Duck, Fuligula Marila-the Black-Head of the Chesapeake, and Broad-Bill of Long Island-for these three are one-being reported to dive for it, and uproot it, while the less vigorous and active Red-Head and Widgeon rob the rightful possessors of it when they rise to the surface after their long dive.

The Red-Head closely resembles the Canvas-Baok, and is often palmed off on the unwary as that bird, yet to an experienced eye the distinction is broadly apparent. In the first place the Canvas-Back is very considerably the larger bird, measuring two feet in length by three feet from wing to wing, and weighing, when in condition, 
full three pounds. The upper parts of the Canvas-Backs are much lighter, and the colors generally clearer and brighter than in the Red-Head, which I consider identical with the European Pochard. It is in the lieads of the two birds, however, that the difference will be most readily perceived, the bill of the Canvas-Back being above three inches long, purely.black, and very high at the base"; whereas that of the Red-Head is bluish, except at the tip, where it is black, and rarely exceeds two and a quarter inches, besides being much flatter where it joins the head. Perhaps the best distinction, however, is in the eye, for that mark is positive, whereas all the others are merely comparative; the iridcs, or circles around the pripil being, in the Canras-Back, deep, fiery red; whereas in the other bird they are of a lurid reddish-yellow or chestnut.

I hare been somewhat particular in insisting on these differences, as I find that there prevails much uncertainty regarding them, and as the pointing out these with precision may protect some fair reacters, if any deign to cast their eyes over this paper, as well as gentle sportsmen, from deception and disappointment.

The Canvas-Back drake, in full plimage, is a magnificently handsome forl, and his speed and power of sustained flight, as well as extraordinary agility and persistence in diving are in all respects commensnrate with his beauty.

The crown of his head, the space between the bill and 
the eye, and the throat, are dusky; the sides of the head, neck all round and the greater part of its length, rich, ruddy chestnut; the lower neck, breast, and back, deep, sooty black, the rest of the back white, closely undulated with narrow black lines; the wing-coverts gray, speckled with black; primaries and secondaries light slate color; rump tail-coverts and tail, blackish; lower breast and abdomen, white; flanks white, finely undulated with gray; under tail-coverts, grayish-black.

The female is iuferior in size to the male, and generally of a dingy, grayish-brown, except the abclomen, which is white, penciled with blackish lines.

This bird is unknown except on this continent, never being found in Europe; and of its habits, except during the winter months, which it spends in our sea-bays and estuaries, little or nothing lras been ascertained, so that of all its most interesting peculiarities in nidification, incubation, and the rearing of its young, we are almost wholly ignorant.

That it breeds in the extreme north we are, of course, assured, and that it is not averse to a more than moderate degree of cold, since it stays with us even after the ice has made, when it can feed only through air-holes, and is never found far south of the capes of the Chesapeake. It does not, moreover, become very abundant even on those its favorite waters, until the cold weather Ias fairly set in, about the middle of November, and a month later it is considered to be in its prime. It is, 
however, very remarkable, that I cannot discover that the Canvas-Back is ever seen or known to visit the great -Upper Lakes, where the Read-Head is also rare, though Widgeon and Scaup abound, and though the northern tributaries of Lake Huron, as well as the flats of the Lake St. Clair are overgrown with all the various plants in which they most delight, both the Vatisneria Americana, and the zizania panicula effusa, known as wild rice, flourishing in wonderful profusion, and imparting their peculiar qualities of flavor, tenderness, and juciness to all the tribes of water-fowl, even the least worthy, which haunt these deep, ice-cold, translucent waters. The only solution I can offer for this seeming anomaly, for all the other ducks pause to recruit awhile in those favorable feeding-grounds while on their southward course, is that the Canvas-Back and Red-Head do not - move en masse from the northern sea-shores, until those great inland waters are girdled around their margins, and winter-bound along their tributary streams by fetters of thick-ribbed ice, and that the fowl in consequence pass over without pausing or becoming known, to their great detriment, to the red or white inhabitants of the coast. Certain it is, that they are unknown to the Indian tribes who dwell on the shores or islands of Lake Huron, and that the officers of the English posts who have known them elsewhere, ignore them here.

To compensate, however, for our ignorance concerning their summer habits, haunts, and proceedings, we are 
well aware of their winter doings and sufferings, for, in truth, from the day of their arrival on the waters of the Chesapeake to that of their departure in the spring, they lave small rest by day or by night, in spite of the exertions of the shooting-clubs to prevent their disturbance by sailing-boats and punts with swivels on the feedinggrounds.

One of their habits is so curious that it merits peculiar attention, though it is shared by these birds with several other varieties, the Scaups, or Black-Heads, and the Read-Heads especially, and sometimes, though rarely, by the Widgeon or Bald-Pates; this habit is a strange hallucination, or curiosity, which induces them to swim directly in from their feeding-grounds, under the very muzzle of the concealed gunner's weapon on the occurrence of any rare or unusual sight, such as an animal at play on the beach, or the waving of a red handkerchief by day, and a white by night. Advantage is taken of this singular propensity to lure them to their doom; and I am assured by a good sportsman that he has known the same flock toled, as it is called, into easy gun-shot and decimated each time, thrice successively within half an hour.

The mode of doing this is thus related by Dr. Sharpless, of Philadelphia, who contributed the account to Mr. Audubon, for his "Birds of America," from whom, with due acknowledgment, I borrow it, never having 
myself enjoyed the pleasure of observing this singular mode of sporting.

For this purpose, says the doctor, "a spot is usually selected where the birds have not been much disturbed, and where they feed at from three to four hundred yards fróm, and can approach to within forty or fifty yards of the shore, as they never will come nearer than they can swim freely. The higher the tides and the calmer the day, the better, for they feed closer to the shores and see more distinctly. Most persons on these waters have a race of small white or liver-colored dogs"-other writers say red, and resembling the fox- "which they familiarly call the toler breed, but which appear to be the ordinary poodle. These dogs are extremely playful, and are taught to run up and down the shore, in sight of the ducks, either by the motion of the hand, or by throwing chips from side to side. They soon become perfectly acquainted with their business, and as they discover the ducks approaching them, make their jumps less high, till they almost crawl upon the ground to prevent the birds discovering what the object of their curiosity may be. The nearest ducks soon notice this strange appearance, raise their heads, gaze intently for a moment, and then push for the shore, followed by the rest. On many occasions I have seen thousands of them swimming in a solid mass direct for the object; and by removing the dogs farther into the grass, they have been brought to within fifteen feet of the bank. When they have approached 
to within thirty or forty yards their curiosity is generally satisfied, and after swimming up and down for a few seconds, they retrograde to their former station. The moment to shoot is while they present their sides, and forty or fifty duclss have often been killed by a sinall grun."

It is said that the tendency to overshoot large, solid flocks is so great that the ollest and best shots reconimend that the nearest duck be brought into full relief above the sight, when your shot will rake the mass. To prevent the toling dogs from breaking, other dogs, crossed between the Newfoundland and water-spaniel, are used, which display even more sagacity than the tolers, crothching when the ducks come in, and springing up eagerly at the discharge, in order to mark its effect. During a flight of fowl, these retrievers are said inces santly to watch the quarter of the hearens whence the fowl are flying, and to indicate their approach by restlessness of manner long before the human eye can detect them.

This toling is not, however, regarded by good and great duck-shots as a very legitimate or sportsmanlike method, and though the sagacity of the dogs, and the gradual approach of the ducks in a way so curious must give an interest and excitement to the business, it must be confessed that blazing away into solid, stationary masses of thousands cannot be compared to shooting on the wing. 
The true and gnostic mode of shooting, however, is from the points or islands, over which the ducks and geese fly in going up or down the bay, according as the wind may be, and on which blinds or screens are constiucted, concealing a seat on which the sportsman quietly and comfortably awaits the advent of the fowl, the teams of which may be seen at a long distance, so that their approach, and the doubt to whose stand they will give the shot, renders the sport most exciting. Retrievers of the same character with those described above, are used in this flight-shooting; and the use of. two heavy fourteen or sixteen pounds single guns, carrying 4 or 5 oz. of No. 1 to $\mathrm{B}$ shot, as I have recommended in my Field Sports for fowl shooting in general, is greatly preferred to that of one double gun, heavier in fact, but as regards each barrel, lighter, and, therefore, neither so safe nor effective as the two singles in succession, and by far less easily managed.

The most celebrated of these stations is Carrol's Island, long rented by a club of sporting gentlemen, and famous for the astonishing sport it was wont to furnish, year after year. The Narrows, also, between Spesutia Island on the western shore, Taylor's Island at the mouth of the Rumley, and Abbey Island at the mouth of the. Bush River, Legoe's Point on the last named stream, and Robbins' and Ricketts' Points, near the Gunpowder, are all farorite and famous stations.

The sport is greatly enhanced by the difficulty of the 
shooting; and it is said that even the best of upland shots, or fowl shots, accustomed only to stooling, fail of success at first in this flight-shooting, from the difficulty of calculating the distance of the teams, and the rapidity of their motion.

And now, gentle readers, for our time, our topic, and our space, are all three exhausted, if you be bound in this, the best month, for the fair Chesapeake, steady be your hands, and sure your eyes ; use Brongh's Hawkers' ducking powder, and Starkey's central fire caps, so shall your guns not fail you. May the winds blow, the tides flow, and the flights fly as yon would liave them. And so farewell to ye; and oh! that we were bound thither likewise, to beat you or be beaton, as it might be. 


\section{THE WINTER DUCK.}

\section{The Lake Huron Scoter.}

\section{Fuligula bimaculata? Canard d'hiver.}

This curious and interesting duck is not described in any book of natural history, relating to the birds of the United States of North America; nor, so far as I can ascertain, is it mentioned or named in any general or local work of ornithology, unless it may possibly occur in Richardson's Fauna boreali Americana, which I have not had an opportunity of consulting.

It certainly is not to be found either in Andubon or Bonaparte, much less in Wilson; nor could the latter be expected to have known it, since in his day the regions which it frequents were scarcely discovered, and at the best visited only by rude frontiersmen and voyageurs, or coureurs des bois, who are not expected to take much note of generic or specific distinctions among the varieties of game, which is regarded by them as little more than food.

It is quite certain, however, that this fine duck is now at least fully entitled to a place in the Fauna of the 


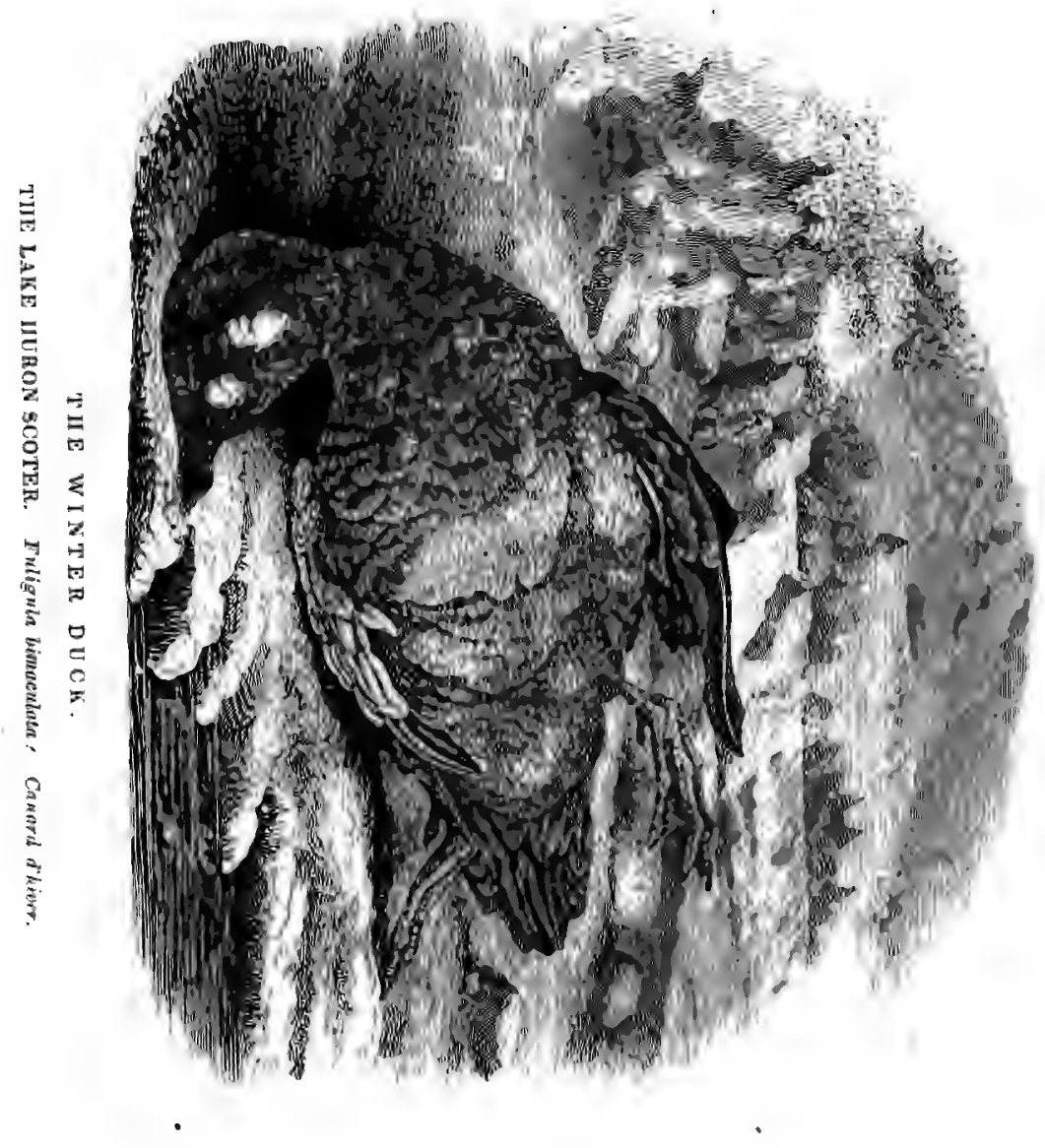



United States, as it has its habitat, during a considerable portion of the year, on waters within their frontiers, and is well-known in the north western regions by the name prefixed to this paper, "Winter-Duck," or among the Canadian French as the Canard d'hiver, being the synonym of the term above used. By the Ojibwa Indians, of Nottawasaga Bay, and the Matchedash, it is known as the "Big Widgeon"-a most inappropriate name, as, beside that it bears no earthly resemblance to the proper widgeon, it entirely differs from that bird in seasons and habits-the Widgeon or Bald-Pate being a summer resident in the north-west and migrating to the sea-coast southward during the cold, winter months. This bird, on the contrary, eomes down, as it would appear, late in the fall, from the extreme north, and winters on the great unfrozen lakes, its southern limit of migration not varying much, so far as I can judge, from the forty-fifth degree of north latitude.

My first sight of this bird was during a visit to the northern shores of Lake Huron and the great Georgian Bay, in company with Lieut. F. C. Herbert, commanding H. M. steam sloop, "Mohawk," then stationed at Penetanguishine. Immediately on entering that beantiful little harbor on a bright morming early in September, before the steamer was at her moorings, a Potawattomie Indian, who could speak no English, came alongside in his bark canoe, with some wild-fowl for sale, which were bought, and handed on deck for inspection. 
At first sight, I was satisfied that the bird in question, one of which was included in the lot, among scaup, or broad-bills, as they are commonly designated on the Atlantic seaboard, mallards, dusky-duck and wood-duck, was a nondescript; and 1 laid it aside to sketch and describe at my leisure. I soon perceived, however, that it had been much mutilated, all the secondaries having been plucked out, and the upper tail-coverts torn away, in order to get at the kernal, from which the birds preen themselves, and which the Indians of that region invariably cut away, and appropriate, for what purpose I could not learn.

In the meantime, I conld learn nothing of the bird among the settlers in the neighborhood, most of them pensioners from the English army, except that it was not uncommon in the fall, in the great bay to the northward of the Manitoulins. The staff-surgeon at the post, himself a good naturalist, was ignorant of the bird, and we carefully examined our specimen by such authorities as were contained in his library, Audubon and Wilson, as well as some small English compendiums on the subject among the number, arriving at the conclusion that it certainly was not described in any of theso works.

Nearly a month afterward, being one of a sporting party, which made a canoeing excursion of a week or ten days, up the Matchedash or Severn river, which discharges the waters of Lake Sincoe, lying midway of the 
peninsula between lakes Huron and Ontario, into the great Georgian bay, I again came across this unknown wild-fowl.

There had been four or five nights of very sharp frost, and ice had formed to the thickness of a dollar, even in the river, which is swift, and in places much broken by falls and rapids. We had cleared the river, and had entered the northern extremity of the lake, Simcoe, paddling as fast as we could toward the village of Orillia, with two canoes running on nearly parallel lines, perhaps a hundred yards apart, when we suddenly saw several large plumps of duck coming from the north. There were, I should think, thirty or forty fowl in each plump, and long before they were nearly within gunshot, I observed that their flight was in itself peculiar, and unlike that of any fowl I had ever observed; for they wheeled and swooped frequently, more after the fashion of plovers, tattlers, or other shore-birds, than of any species of duck with which I was previously acquainted ; and these movements were the more conspicuous, on account of the broad white bar's across their wings, formed by the secondaries, which were alternately seen and lost at every motion.

At length, one of the smallest flocks wheeled in between the two boats, and got the contents of three double-barrels, beside the charges of two or more 'ong north-west Indian pieces. A good many birds were knocked over, quite dead; and a good many more 
scattered away, and dropped, more or less severely hurt, over the clear waters of the bright, sunny lake; while the main body, or what was left of it, settled down and was marked by the Indians, on our course toward Orillia. Some considerable time was occupied in taking the cripples; which were all dispersed, and which swam away rapidly as the canoes approached them, none of them making any attempt at rising again on the wing, seldom diving except when very hard pressed, and then only for a little time and short distance.

When the wounded were all fairly brought to bag, the Indians were in great glee, and asserted that they could paddle us upon them all; which I should have been inclined to doubt, had I not learned how very rarely an Indian hazards an assertion of which he is not perfectly well assured, especially to a white man; for the duck lay full in bright water, in the middle of the lake, which was as clear and smooth as a piece of glass, with a bright sun shining; and our canoes were large and full of men; nor was there a particle of wild-rice or sedge whereby to cover our approaches.

Nevertheless, An-oon-ge-zhig, or the "Starry-Sky" for so was our principal conductor styled, made his prophesy good; for he did paddle us directly on the birds, and we slaughtered them, as they sat on the water without offering to fly at our approach, until we had bagged the greater part of the whole plump.

On the following day, having attained the limit of our 
-intended excursion, we put our heads to the north-westward, and bent our way homeward, the cold weather suddenly giving way on the noon of the second day; after which we enjoyed the most delicious Indian-summer weather I have ever witnessed.

During the whole of our run down the Matchedash, and through the innumerable rice-lakes into which it expands, we had great sport with these same birds, which we killed in very considerable numbers, while daily we could observe them coming in by great flights from the north; though, on our way up, only three or four days previously, we had not seen a single bird of the kind, though we had shot many scaups, mallard, and dusky-duck; and not a few buffel-heads, called by the Indians spirit-ducks, from the rapidity with which they vanish from the eye when diving at the flash.

The first thing which struck me on examining the specimen shown to me on board the "Mohawk," was. the peculiar formation of the head and bill, and the position of the wings and legs; all indicating it to be of the class fuligulce, or sea-ducks, and of that coarse, and for the most part uneatable, species, generally known along our sea-board as "Coots"-although "the true coot is an entirely different species, haunting fresh-water pools, and belonging to the order of grallatores, distinguished from the ducks by having only semipalmated in lieu of webbed feet.

The known birds of this genus of fuligulos, or sea- 
ducks, as established by the authorities, and belonging to the United States, are sixteen in number, all of which are entirely familiar to me. Of these, seven have the bill peculiarly formed, or I might say deformed, with curious protuberances at its base, and the feathered forehead running far down the dorsal, or upper, outline of the bill, almost to the nostril.

These seven are the Eider-duck, the Ring-duck, the Harlequin-duck, the Pied-duck, the Velvet-duck, the Surf-duck, and the American Scoter; of these, the three last, to all of which this bird bears a very considerable resemblance, are known as "coots" on the sea-shore, and are distinguishable by what may be called the scoter bill, high, and more or less carunculated at the base, and often variegated with several bright colors.

It is remarkable, that of this genus of Futigulae, eight are of the most, two of these the very most, delicious of all water-fowl on the table; I need not specify the "Canvas-back," and the "Red-head," as their names will occur spontaneously to every sportsman, every gourmet in the land-while the other eight, including the Long-tailed duck, Old-wife, or South-southerly, are fishy, rank, oily; an uneatable abomination. On the strength of the similarity of the Winter-duck of Lake Huron, to the Scoter family-of the sea-ducks, I at once prophesied that it would prove, like its congeners, uneatable. My surprise may be imagined when it turned out -not by the camp-fire, where, with the Spartan sauce, 
all meat is appetizing-but at the comfortable dinnertable, with all appliances and means to boot, at Penetanguishine, whither we conveyed our booty, one of the most delicious duck I ever tasted, and not unworthy to be named alongside of the royal Canvas-back himself. It was not, in the least degree, fishy or sedgy; but rich, succulent, delicate, and melting in the mouth, like the fiesh of the fattest duck that ever fed in the Gunpowder or the Potomac-the cause of which undoubtedly is this, that in both localities, the food of the fowl is the same, the seeds of the wild-rice, zizania panioulâ eff $u \hat{u}$, the wild-celery, valisneric Americana, and the eel-grass, xostera marina; all which, or varieties of them, are universally found in all the flats and mud-lakes of that region.

On our return to convenient quarters, I immediately set myself to work to dissect a sufficient number of these fine fowl to satisfy myself as to the distinctions of the sexes as to plumage and coloring; to take careful measurements, and draw up accurate descriptions; besides making a close and correct drawing of the bird from nature. From all that I have since been enabled to collect, I am well satisfied that this is a new and undescribed sea-duck from the arctic regions. I have neverfound any one, though I have consulted many sportsmen and naturalists, who is acquainted with the bird southeast of the straits of Mackinaw. At Detroit it is unknown, as also on the Canada shores, and that to 
persons in the continual habit of shooting fowl on the great rice-flats of Algonac on Lake St. Clair, on the Chatham marshes at the mouth of the Thames river on the same lake, and on the pine-swamps of the Aux Canards, near Amherstberg, an affluent of the Detroit river-all of which localities are literally alive with wild-fowl at the proper season.

I have since heard from an officer in H. M. Royal Canadian Rilles of two of those birds being killed near Prescott, on the St. Lawrence; but they were utterly unknown to the inhabitants there; and he wrote to me to make inquiries as to their species and name. During the present summer I learned also, from my friend $\mathrm{Mr}$. Dotty, M. C. for Wisconsin, that during the whole winter they are exceedingly abundant, wherever open water is to be found, on Lake Winnebago and the rivers of that region, coming late in the autumn and disappearing in. the spring.

Every thing, therefore, confirms me in my first idea, that this is an as yet nondescript duck, nondescript certainly as a fowl of the United States, whose summer haunts are far up in the arctic seas, and the winter limits of whose migrations do not extend below $44^{\circ} 30^{\prime} . \mathrm{N}$. latitude. In this view, I have taken the liberty of suggesting, should it prove to be litherto undescribed and unnamed, the propriety of designating it the "Lake Huron Scoter," from its locality, and its resemblance to that class of ducks, and, in Latin, "Fuligula bimacu- 
lata," from the two white spots which are its most distinguishing characteristics.

The wood-cut at the lhead of this article is mathematically reduced from my own original sketch, and it may be described as follows :

Specific Charactei.-Head elongated, elevated toward the coronæ; forehead protruding, feathered one-third the length of the bill; bill much elevated along the dorsal ontline, decurved and flattened toward the tip; a broad nnguis on both mandibles; nostril oval, pervious, one-third nearer the tip than the base; both mandibles deeply lamellated along the gap. Neck short, stout. Body broad, thick, and much depressed; wings short, and placed far back; legs stout, situate very far, back, scutellate in front, reticullate behind; tail short, acutely ovate; two centre feathers longest.

Plumage.-Thick, soft, densely compressed, much blended, and having an under-stratum of soft, blackish down.

Colors.-Bill, bluish black, without any other tint; irides hazel; legs, in the adult males, dusky crimson, in the females dull orange; claws black; webs black and grained like morocco leather; crown of the head, nape shoulders, back, upper tail coverts, and tail, sooty black; chin, cheeks, forepart of neck, and upper breast, sleek, satiny mouse color. A triangular white spot at the base of the upper mandible, extending to the anterion angle of the eye; a larger, irregular, oblong white spot below 
and behind the posterior angle of the eye. Forepart of breast, belly, and vent dull, silvery gray; flanks and under tail coverts darkish, glossy, mouse colored. Scapularies, wing-coverts and tertials, dull brownish black; secondaries broadly-banded with white, forming the speculum; primaries jet black, under-wing coverts silvery mouse colored.

Measurements.-Head 5 inches, tip of bill to nape; bill 24 4-10; length, to tip of tail, 24 inches; to tip of claws $25 \frac{1}{2}$; length of tarsus $17-10$; length of middle toe $26-10$; length of wing $9 \frac{3}{4}$; length of middle tail feathers $21-5$; extent 27 inches.

The male bird weighs from $2 \frac{1}{2}$ to 3 pounds; and differs from the female only in weight, size, greater distinctness of colors, and liue of the legs.

This duck, for its size, weight and power on the wing, when in full flight, is very easily stopped with moderate sized shot; and is almost equal on the table as I have observed above, to the canras-back. With decoys, immense sport might be had off these birds in the riceIakes which they frequent; and with or without them, I would desire no better fun, than to be, under this clear moon beneath which I pen these lines, in a fleet birchbark canoe, with my old friends An-oon-ge-zhig, and the "Young Owl," to paddle me upon the fowl among the solitary rice-lakes of the lovely Matchedash. My life on it, if we should sleep on hemlock tips rith a canp-fire 
at our feet, and no covering above us, but our blankets and the bonny lady moon, we should not fall asleep without both play and supper! Telenimicoon! to those who understand it!

IINIS. 



\title{
$\mathrm{HE} \mathrm{A} \mathrm{DL} \mathrm{E} \mathrm{Y}^{\prime} \mathrm{S}$
}

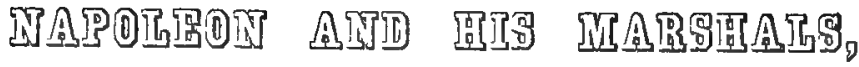

TLLTSTRATED WITII

\author{
OVER SIXTY FINE ENGRAVINGS.
}

\section{CHARLES SCIRIBNER}

IIS JUST PCBLISIED

A New and Illustrated Edition of NAPOLEON AND His MaRsLaLS. By J. T. IThadum. 1 vol. 8vo. Orer sixty Illustrations. Price, $\$ 3.00$.

\section{LIST OF ILLUSTRATIONS.}

Nrpoleon as General.

" at Crannno.

Bonaparte presenting to the I)ircetory the Treaty of Campo-Formio.

Capitulation of UIm.

The Mob at the Tuillories.

Napoleon reprimanding the Division of Vaudois.

Napoleon as Emperer.

Arrest of the Duke D'Enghien.

Return from Elbn.

Departure from Fontainblean.

Deatlu of Napoleon.

Passage of tho Bridge of $\mathrm{Ar}$ rola.

Marshal Davoust.

Nupoleon at Krisnoe.

Denth of Moreal.

Marshal Lammes.

II soldher's procitim hinn "Corporal."

Tiattle of Aboukir.

Charre of Chirussiers at Eylau.

Instrroction at Madrid.

Mirshul Massena.

“ Victor.

Tassage of the Beresing

Jeath of Duroc.

Buttlo of Lutzen.

Mrrshal Bessieres.

Passage to the Tagliamento.
Napoleon Dissolving the Council of Iive Funcired.

Parsage of the Great St. Bornard.

Battle of Mircince.

Sicure of Sarngossa

Death of Minshal Lannes.

It is a King of Tinme.

Interior of the Invalides.

The Funeral Car.

The Exhumntion.

Marshal Mac!ionald,

Buttle of Wagram.

Napolcon Visiting the Rulns of Dierstoin.

The Jurning of Moscow.

Combat of Fere Champenoise.

Marshal Soult.

Battle of Austerlitz.

Marslial Murnt.

I'assage to the Niemen.

Marshal Suchet.

Denth of Poniatowskl

The Forty-Third Demi-Brigale at the Eattlo of IIohenlinden.

Napoleon at Montereain

Mrrshal Ney.

Iiattle of Jena

Napoleon Retrenting from Moscow.

Lord Wellington. 



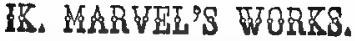

TIIRTECTIH HDITION OE

\section{REVERIES OF A BACHELOR, a Book of the Heart. By IF. Marver, 1 roh} 12mo., with Illustrations by DARLTT.

The Illustrated Edition, with Twenty-five Illustrations, will be ready about the eniddle of October.

"Quotations givo but a faint idea of the depth of, foeling, the beautiful and winning frankmess, the olastle vigor of soul, and the singular fldelity of expression which characterize this remarable volume. Its quaint ingenaity of arrangement is wholly lost in extracts; and in order to enjoy the delicious adaptation of form to sentiment in which it would be hard to namo its equal, it must bo read as a consummate, artistic, gem-lije whole," - . Y. Tribune.

"The dreamy, shadowy haze of reverie, its fleet transitions, its vivid and startling passages-more vivid, oftentimes, than anything of real life-are admirably reproduced on these delicate pages. The dense and delibernte style, though rowise itselp dreamy and insubstantial, dealing largely rather in the tough and oaken Saxon, that zoakes the strength of our hardy tongue, is adapted with admirable pliancy to the movement and tone of the fancy. There are passages in it-as those descriptive of early separations, schooldays and their sequel-that will start the memory, with a quick throb, in many hearts. And there are essential and permanent qualities exhibited in it, both of intellect and of sensibility, that give noble promise of a fiuture, and that will make the subsequent publications of the author events to be watched for."-Independent.

The writer who can lare a few of his fellow mortals away from the bustle, and the strife, and the fret, and the weer and tear of a restless existence-who can plant thern in his own quiet arm-chair, and think a little for them so easily and so cosily that they shall fancy his thoughts to be their own soliloquies-who can carry them off from the engrossing present, backward to the fallness of youth, or forward to the repose of agevho can peel off, here and there, the worldly rind that grows ever-thickening over the heart, growing fastest and thickest in the hothouses of fashion, and in the rank soil of wealth-the writer, we say, who ean do this-Mr. Ik. Marvel does it in his Reveries-shall be welcomed to a place in our regards, and cordially recommended to our readers' bookshelves,"-Abbion.

"This is a pleasant and clever book; racy, genial, lively and sparkling. It is a book to put one in good humor with himself and all the world."Southern Literary Gazette.

"It is an exquisite production, the like of which the press has not produced in this country or in England. Portions of it remind us forcibly of some of the old, and almost unknown French authors, whose sketches of thought and feoling we have never secn cqualled for delicacy and truth, until we read these Roveries. The book is especially welcome as one of a new class in this country, which appeals to all the finer feelings of the Leart." - Journal of Commerce.

4 Well hns the anthor cnlled it a book of the heart. Not of a heart withered by selfishness, mistaking disappointment for sorrow, hatred of the world's joys for philosophic contempt; but a generous, noble heart, that has sorrowed as we have sorrowed, that can echo back from the distant hills of its own experience our own cries-now of joy, now of grief and our songs of quiet happiness." $-N$. Y. Courier and Inquirer. 


\section{"THE FALI OP POLANBD,"}

Containing an Analytical and a Philosophicsi Account of the Canses which Conspired in the Ruin of that Nation; together with a history of the country from its origin. $\mathrm{By}$, L. C. SA TTON. 2 vols, 12 mo, pp. 563, 621.

The entire work is no hasty uttercnce of crade opinions, for the anthor has evidently fitted himself for the task he has undertaken, by a study of history generally, and particularly by a careful collation of all those writers that bear upon the subject.

In order to be more complete, tho various topics are arranged under different heads, as Religion, Government, Great Men, Civilization, Society, \&c., thus enabling the student to refer direetly to the subject which he may desire to see, and fitting it, with its appropriate index, to make a valuable work for the library.-Newoark Daily Advertises.

He has gone into his subject with thoroughness and a scrupulous regard to accuracy in detail, having been many years in gathering his materials, and giving them symmetry and form,-Ervening Transoript.

The work abounds with thrilling incidents and vivid, not to say gorgeous descriptions, as well as in valuable historic detail.-Albany Arous.

It is the produet of great thought and research, and presents a complete and accurate view of the History, Government, Laws, Religion, Popular Character, Literature, and in short everything connected with Poland that can have an interest for the seholar or the stateaman. The author writes with great vigor and clearness, and his work is constructed throughout upon the best principles of historical science. It is a solid, symmetrical, and glowing ineorporation of all the great points of interest of one of the most interesting nations of modern times; and deserves to be placed among the enduring ornaments of American literature.-Courier and Enquirer.

These volumes embody a full and continnous history of Poland from the earliest ages of its existence, in which are included the several dynasties ander which it has been governed, with reference to every suhject which throws light on the principles of its government, its varying prosperity, its literature, its distinguished men, its religion, and the character of its people. The author has consulted éverything which has been written on the history of Poland which was accessible; has placed bis materials under a clear arrangement, and has subjected the whole to a carefol analysis. There is no other book extant, in which so much has been compressed on the anbject of Poland, and which may more safely be referred to as an authority.-Philadelphia Presbyterian.

A map and engravings add interest and value to a bistory which Mr. Saxton has prepared with great labor and caro. Wo know zot where else to look for so much in the samg compass, relating to a nation whese tragic career has drawn to it the attention and sympathy of the civilized world. The construction of the work is in many respects a model for books of this class, giving, as it d)es, an answer to the inquiries that are naturally suggested to the mind of the inquisitive render, who will not rise from the perusal of so complete a survey of Poland and its history, without feeling himself informed at almost every point to which his inquiries may be directed.-Watchman and Reflector.

The author's style is terse and vigorous; his conclusions enforced by arguments based npon well establisher facts and sound philosophy; and the work, as a whole, we consider a valuable accession to modern listorical contributions. It is worthy the patient study of the student of history, and cminently deserving a place in every private as well as publie library.-Troy Daily Whig.

It is a book which the statesman may read with profit, whlle it is also vell calculated to interest the general reader. Especially would we commend it to the perusal of the student, who will find many things "both now and old" within its lids-Freeman's Joumal.

This work recommends itself to public nolice by its clear and concise history of a coun 





